Universidade de São Paulo

Escola Superior de Agricultura "Luiz de Queiroz"

Caracterização da madeira de teca plantada em diferentes idades e regiões para produção de piso

\title{
Vanderlei Benedetti
}

Dissertação apresentada para obtenção do título de Mestre em Ciências, Programa: Recursos Florestais. Opção em: Tecnologia de Produtos Florestais

Piracicaba

2018 
Vanderlei Benedetti

Engenheiro Florestal

Caracterização da madeira de teca plantada em diferentes idades e regiões para produção de piso

versão revisada de acordo com a resolução CoPGr 6018 de 2011

Orientador:

Prof. Dr. GERALDO BORTOLETTO JÚNIOR

Dissertação apresentada para obtenção do título de Mestre em Ciências, Programa: Recursos Florestais. Opção em: Tecnologia de Produtos Florestais 
Dados Internacionais de Catalogação na Publicação DIVISÃO DE BIBLIOTECA - DIBD/ESALQ/USP

Benedetti, Vanderlei

Caraterização da madeira de teca plantada em diferentes idades e regiões para produção de piso / Vanderlei Benedetti. - - versão revisada de acordo com a resolução CoPGr 6018 de 2011. - - Piracicaba, 2018.

$107 \mathrm{p}$.

Dissertação (Mestrado) - USP / Escola Superior de Agricultura "Luiz de Queiroz".

1. Propriedades mecânicas 2. Elementos anatômicos 3. Secagem 4. Índice de conversão I. Título 


\section{DEDICATÓRIA}

"No incentivo senti seu apoio, no silêncio, sua preocupação, mas se em momento algum eu desisti foi por seu amor e dedicação! Aos nossos filhos, a oportunidade de deixar um pouco da nossa insistência e esforço, vivendo para eles em todos os momentos! A você Estela e as eternas crianças, Vitor e Gabriel" 


\section{AGRADECIMENTOS}

À ESALQ pela oportunidade para a realização dos estudos, principalmente ao professor Geraldo Bortoletto Júnior, pelo apoio, orientação, amizade, ensinamentos e pelo uso do LEMAD - Laboratório de ensaios mecânicos de madeira e derivados da ESALQ. À empresa TRC - Teak Resources Company do Mato Grosso, de forma especial ao Eng. Fausto Takizawa e a Carlos Alberto Cunha Oliveira da Implantar Florestal pelo fornecimento das toras para o estudo e apoio logístico para coleta e envio do material de estudo. À Serraria Baggio, em nome dos proprietários Paulo Baggio e Luiz Natale Baggio, que forneceram toda a infraestrutura para beneficiamento das toras. Aos diretores da Indusparquet Indústria e Comércio de Madeiras Ltda, José Antônio Baggio e Francisco Uliana pela infraestrutura cedida e todo apoio para a produção dos pisos e, também, aos funcionários da Indusparquet, Sebastião Roberto Rodrigues, Milton José do Amaral, José Maria Serafim, Pedro Milton Paulo da Silva, Edson Schiave, Vagner Botega Giacomazzi e Robison Luiz Arruda, por toda a paciência, tempo e mão-de-obra disponibilizada para a produção do piso de teca com a melhor qualidade. Ao professor Mário Tommasiello pelo suporte, ensinamentos e grande apoio no uso do Laboratório de Anatomia, Identificação e Densitometria de Raios X em Madeira, da ESALQ. Aos professores Ivaldo Pontes Jankowsky, Adriana Maria Nolasco da ESALQ e Alexsandro Bayestorff da Cunha da UDESC pelo suporte, ensinamentos e sugestões ao trabalho. Ao professor Francides Gomes da Silva Júnior pela logística no Laboratório de Química, Celulose e Energia da ESALQ. Aos funcionários do Departamento de Ciências Florestais Alex Canale, Aparecido Candido Siqueira, Maria Aparecida Bermudez, Luís Eduardo Facco pela valiosa ajuda em todos os momentos. Aos colegas Caio César Faedo de Almeida e Diego Lima por todo trabalho, apoio e discussões. Aos colegas de mestrado e doutorado do Departamento de Ciências Florestais pelos momentos e conhecimentos compartilhados. 


\section{BIOGRAFIA}

Esposo de Ana Estela Rambaldo Benedetti, pai de Vitor e Gabriel. Engenheiro Florestal, graduado pela ESALQ Escola Superior de Agricultura "Luiz de Queiroz" - USP em 1983. Com 35 anos de experiência na área florestal. Trabalhou na área ambiental, de pesquisa e operacional de várias empresas florestais. Consultor desde 1997, já tendo trabalhado com diversos clientes no Brasil e pelo mundo afora. Editor do livro "Nutrição e Fertilização Florestal", em português e inglês. Atualmente, grande defensor do plantio de teca no Brasil e do uso da sua madeira. 


\section{EPÍGRAFE}

"Eu pego num livro velho com reverência; sinto nele a substância inerente a toda criação do espírito: o desejo de alongar as fronteiras da existência, pela reflexão ou pelo sonho acordado ... "

Carlos Drummond de Andrade, citado por José Leonardo de Moraes Gonçalves no livro: Fertilização e Nutrição Florestal. 
SUMÁRIO

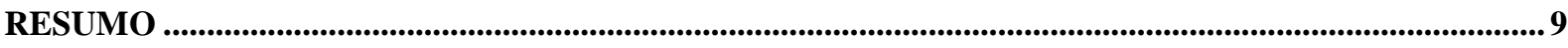

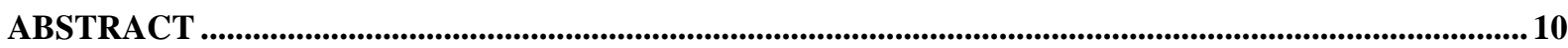

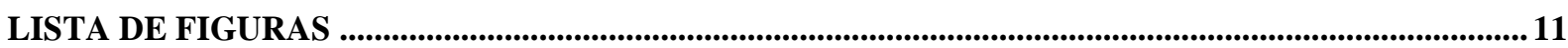

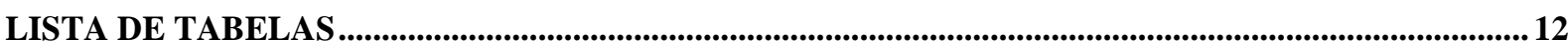

1. INTRODUÇÃ

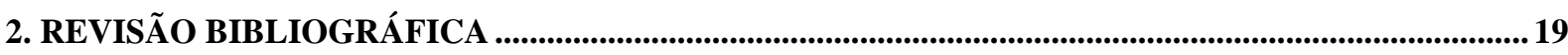

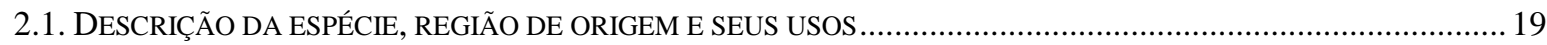

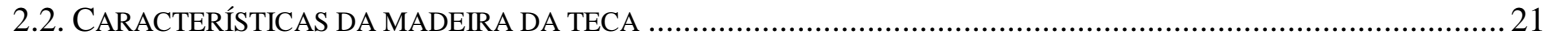

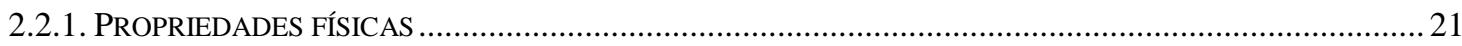

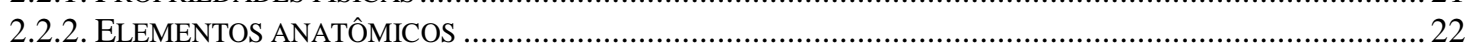

2.2.3. TEORES DE EXTRATIVOS NA MADEIRA DE TECA .................................................................... 23

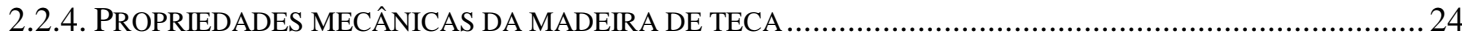

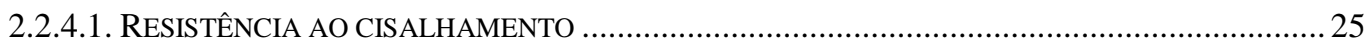

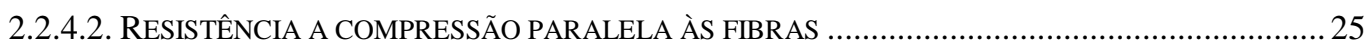

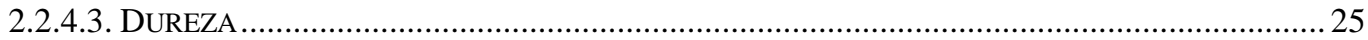

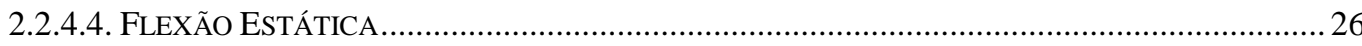

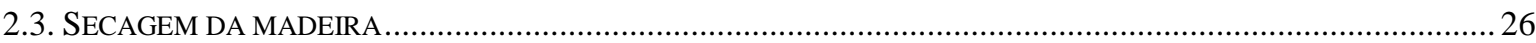

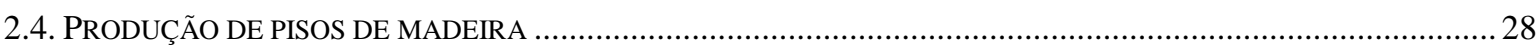

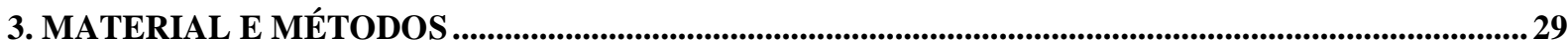

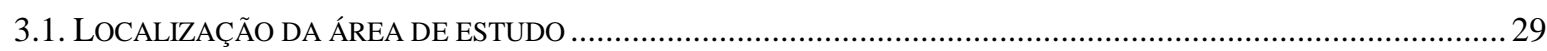

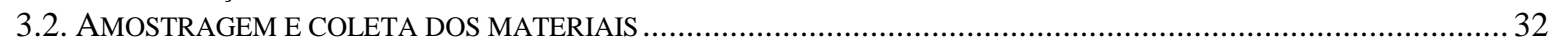

3.3. VOLUME COMERCIAL, ÁREA DA CASCA, MEDULA, CERNE, ALBURNO; PROPORÇÃO CERNE/ALBURNO E

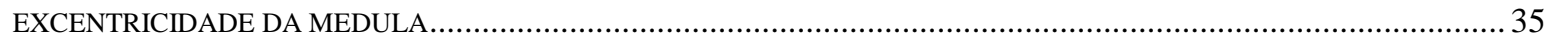

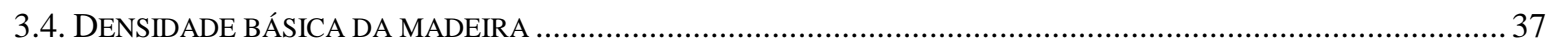

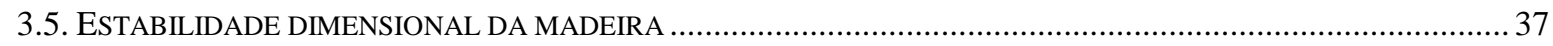

3.6. PROGRAMA DE SECAGEM PELO MÉTODO SIMPLIFICADO DE SECAGEM DRÁSTICA ….................................38

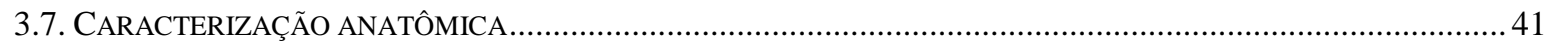

3.7.1. PREPARO DAS LÂMINAS HISTOLÓGICAS ........................................................................... 41

3.7.2. MENSURAÇÃO DOS ELEMENTOS ANATÔMICOS DISSOCIADOS (MACERAÇÃO) .................................. 41

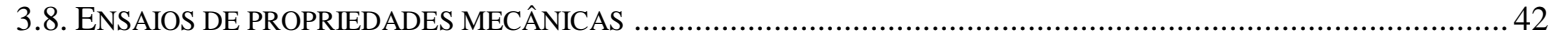

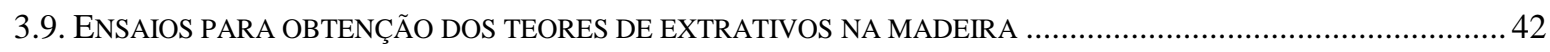

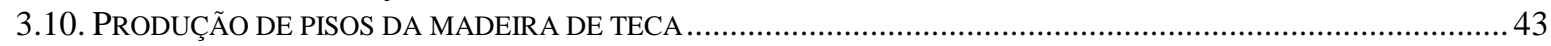

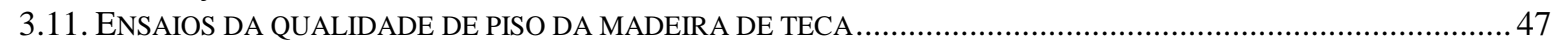

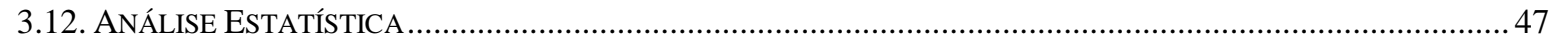

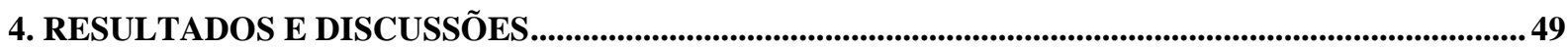

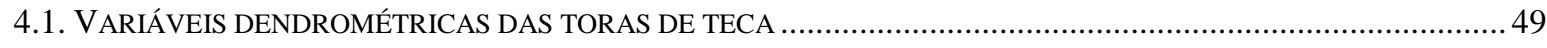

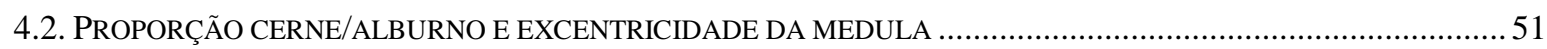

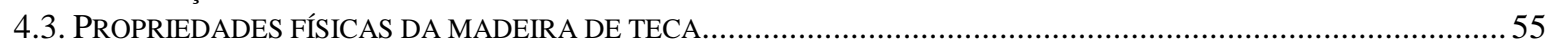

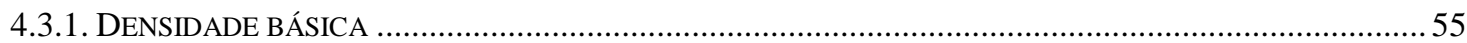

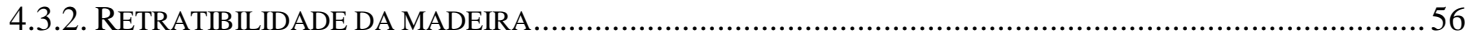

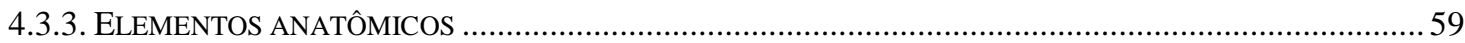

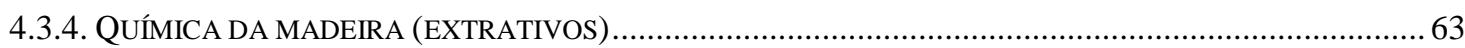

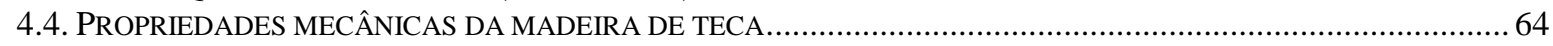

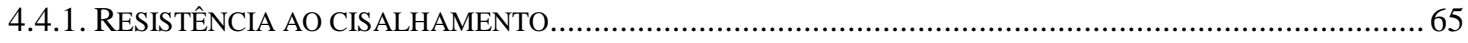

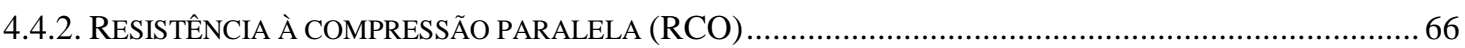

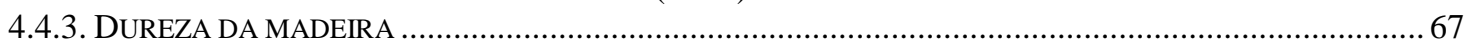

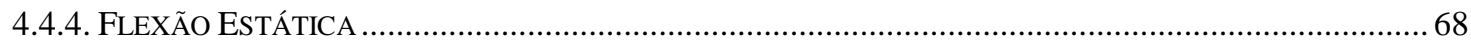

4.4.5. COMPARAÇÃO DOS RESULTADOS DE PROPRIEDADES MECÂNICAS COM OUTRAS ESPÉCIES ...............70

4.5. CORRELAÇÃO DE PEARSON ENTRE A DENSIDADE BÁSICA, AS PROPRIEDADES MECÂNICAS E AS DIMENSÕES

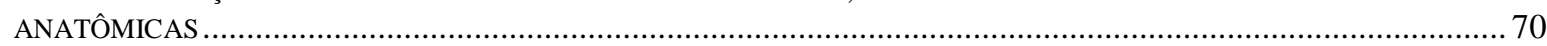

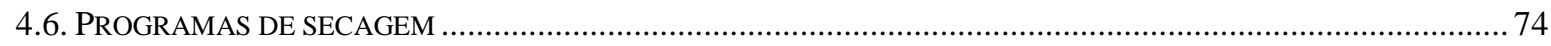




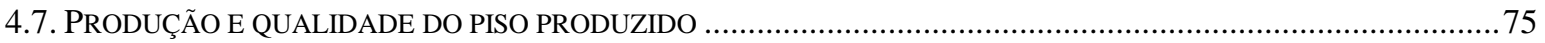

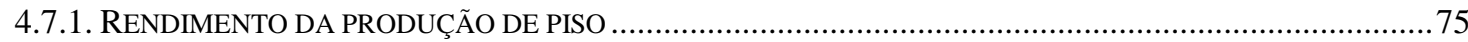

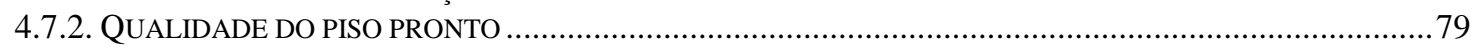

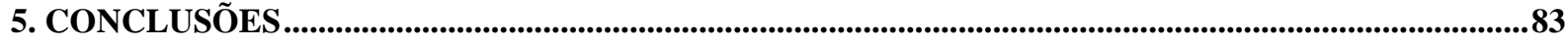

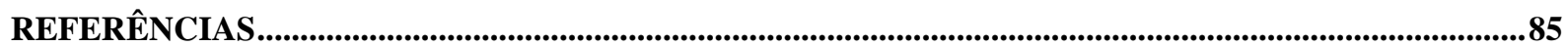

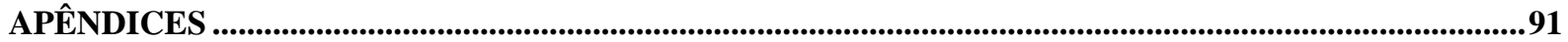




\section{RESUMO}

\section{Caracterização da madeira de teca plantada em diferentes idades e regiões para produção de piso}

O objetivo desse trabalho foi avaliar as características anatômicas e químicas, as propriedades físicas e mecânicas, obter o rendimento do processo de produção de piso e sua qualidade e elaborar programas de secagem simplificada da madeira de árvores de teca (Tectona grandis L. f.) de plantações florestais seminais em diferentes idades, aproximadamente 9,5; 14,4 e 18,7 anos, provenientes dos municípios de Glória D’Oeste, Porto Esperidião e Rosário D’Oeste no Mato Grosso e de Angatuba no estado de São Paulo com idade de 9,4 anos. As toras obtidas desses povoamentos foram processadas para obtenção de amostras destinadas às referidas avaliações, bem como para produção de lotes de pisos de madeira maciça, os quais também foram analisados através de ensaios específicos de qualidade. Foram determinados os programas de secagem da madeira para cada um dos tratamentos, usando-se o método simplificado de secagem drástica. Através dessas avaliações e análises pretendeu-se verificar se as propriedades da madeira de teca, independentemente da idade, região e manejo, apresentam resultados similares, bem como se os pisos produzidos com o uso de madeiras de desbaste e com idade mais jovem mostram qualidade análoga aos produtos gerados com a madeira proveniente de florestas com idade definida para cortes intermediários e finais. A mesma avaliação foi realizada comparando-se a madeira produzida nos estados do Mato Grosso e São Paulo, na idade de 9,5 anos, para verificar possíveis diferenças na qualidade da madeira, devido às variações climáticas, de solo e de manejo. Os resultados apresentados mostram que o manejo da floresta, principalmente, em relação à densidade populacional inicial, influenciou o crescimento das árvores. A idade influenciou o maior diâmetro e volume individual das árvores. O volume e porcentagem de cerne apresentou a mesma tendência, aumentando com a idade, já a excentricidade da medula reduziu com a idade. A estabilidade dimensional foi menor no plantio de SP, devido às diferenças climáticas mais acentuadas e a maior população inicial do povoamento. Há correlação positiva entre a densidade básica e todas as propriedades mecânicas estudadas, bem como com algumas dimensões anatômicas como comprimento das fibras e espessura da parede. Não houve nenhuma correlação entre a idade dos plantios e as propriedades físicas, mecânicas ou anatômicas. Quanto maior a idade da floresta, maior foi o índice de conversão no processo de produção de piso. Entretanto, o volume de piso gerado por área foi maior na floresta com melhor manejo adotado, ou seja, menor densidade populacional inicial. Dentre os tratamentos avaliados o plantio com 9,5 anos do MT apresentou melhor produtividade de piso por área, o que mostra que esse tratamento, associado a essa finalidade, é mais vantajoso economicamente do que os outros, mas é necessária uma avaliação dos custos de produção do piso. Isso denota que o manejo aplicado nessa área, principalmente quanto a menor densidade populacional na implantação da floresta, apresentou melhores resultados de produção total de toras e conversão para piso e boa qualidade do produto final.

Palavras-chave: Propriedades mecânicas; Elementos anatômicos; Secagem; Índice de conversão 
ABSTRACT

Characterization of teak wood planted in different ages and regions for floor production

The purpose of this work was to evaluate the anatomical and chemical characteristics, physical and mechanical properties, obtain the yield of the flooring production process and its quality and to elaborate programs of simplified drying of the wood of teak trees (Tectona grandis L. f.) of plantations forest at different ages, approximately 9.5; 14.4 and 18.7 years, from the municipalities of Glória D'Oeste, Porto Esperidião and Rosário D'Oeste in Mato Grosso, and from Angatuba in São Paulo state, aged 9.4 years. The logs obtained from these stands were processed to obtain samples for the said evaluations, as well as for the production of lots of solid wood floors, which were also analyzed through specific quality tests. The drying programs of the wood were determined for each of the treatments, using the simplified drastic drying method. Through these evaluations and analyzes it was sought to verify if the properties of the teak wood, regardless of age, region and management, present similar results, as well as if the floors produced with the use of thinning woods and younger age show similar quality to the products generated with the wood coming from forests with defined age for intermediate and final cuts. The same evaluation was carried out comparing the wood produced in the states of Mato Grosso and São Paulo at the age of 9.5 years to verify possible differences in wood quality due to climatic, soil and management variations. The results show that the forest management, mainly in relation to the initial population density, influenced the growth of the trees. Age influenced the largest diameter and individual volume of trees. The volume and percentage of heartwood presented the same tendency, increasing with the age, but the eccentricity of the marrow reduced with the age. The dimensional stability was lower in SP planting, due to the more pronounced climatic differences and the greater initial settlement population. There is a positive correlation between the basic density and all the mechanical properties studied, as well as some anatomical dimensions such as fiber length and wall thickness. There was no correlation between planting age and physical, mechanical or anatomical properties. The higher the forest age, the higher the conversion rate in the flooring production process. However, the flooring volume generated by area was higher in the forest with better management adopted, that is, lower initial population density. Among the evaluated treatments, the 9.5-year old plantation in MT presented better flooring productivity per area, which shows that this treatment, associated with this purpose, is more economically advantageous than the others, but an evaluation of the flooring production cost is need. This indicates that the management applied in this area, mainly as the lower population density in the forest implantation, presented better results of log total production and conversion to flooring and good quality of the final product.

Keywords: Mechanical properties; Anatomical Elements; Drying; Conversion rate 


\section{LISTA DE FIGURAS}

Figura 1. Piso de madeira maciça de teca obtida de árvore desbastada em plantio florestal de Angatuba/SP, aos

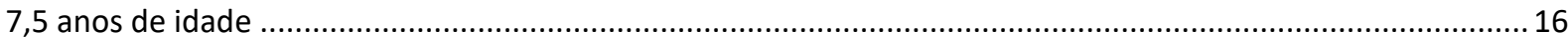

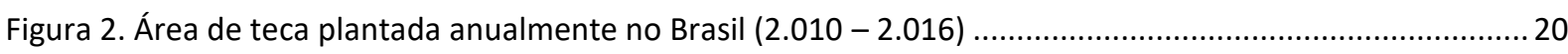

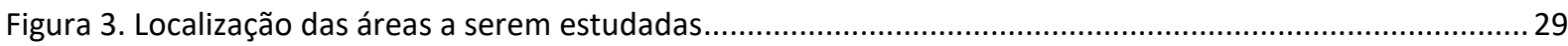

Figura 4. Esquema da coleta de amostras de madeira de teca para ensaios das propriedades físicas e mecânicas; dimensões anatômicas; determinação do teor de extrativos e ensaio de secagem drástica ..............................32

Figura 5. Esquema da coleta de amostras de madeira de teca para ensaios das proporções de cerne / alburno; excentricidade da medula e produção e avaliação da qualidade de pisos

Figura 6. Pranchas retiradas de 5 árvores médias do tratamento de Angatuba/SP (plantio com 9,4 anos de idade) para ensaios mecânicos.

Figura 7. Toretes de 1,35 metros retirados de uma árvore média do tratamento de Angatuba/SP (plantio com 9,4 anos de idade) para produção de pisos e da determinação da relação cerne / alburno e excentricidade ............ 35

Figura 8. Disco fotografado para cálculo das áreas de medula, cerne e alburno e do valor de excentricidade da

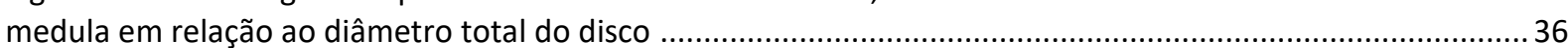

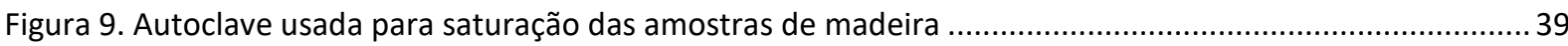

Figura 10. Esquema demonstrativo da quantificação de intensidade do colapso ............................................41

Figura 11. Plaina desempenadeira usada para alisamento de um dos lados das toras de teca ..........................43

Figura 12. Serra fita usada para corte das tábuas de teca ......................................................................44

Figura 13. Secagem da madeira de teca em secador comercial da Indusparquet ............................................44

Figura 14. Produção de piso maciço de teca em moldureira da Indusparquet ............................................... 45

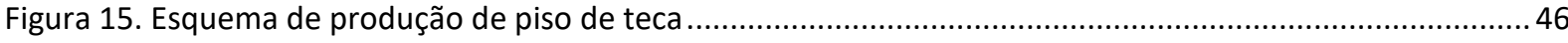

Figura 16. Volume comercial individual das árvores de teca em diferentes idades e regiões .............................50

Figura 17. Espessura dos anéis de crescimento em todos os tratamentos ....................................................... 51

Figura 18. Correlação entre DAP e Volume do cerne para madeira de teca de três áreas e idades do MT, com 9,5; 14,4 e 18,7 anos e uma área de Angatuba/SP, com 9,4 anos de idade.

Figura 19. Porcentagem média por árvore dos componentes cerne e alburno nas toras de teca amostradas no Mato Grosso em diferentes idades (9,5; 14,4 e 18,7 anos) e em Angatuba/SP na idade de 9,4 anos

Figura 20. Corte transversal da madeira de teca de uma árvore da Fazenda Sta. Maria do Jauru, em floresta com

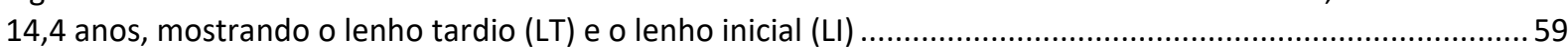

Figura 21. Comprimento das fibras $(\mu \mathrm{m})$ das árvores de teca das Fazendas do MT e de SP 59

Figura 22. Correlação entre idade (anos) e o teor de extrativos (\%) de teca nos tratamentos do Mato Grosso e em São Paulo, nas idades de 9,4; 9,5; 14,4 e 18,7 anos ..............................................................................64

Figura 23. Correlação entre a densidade básica e as propriedades mecânicas da madeira de teca .................... 72

Figura 24. Correlação entre as dimensões anatômicas e as propriedades mecânicas da madeira de teca.......... 73

Figura 25. Rendimento de toras, tábuas beneficiadas e pisos produzidos das amostras de madeira das florestas com 3 idade no Mato Grosso (9,5; 14,4 e 18,7 anos) e em Angatuba/SP com 9,4 anos de idade.....

Figura 26. Rendimento de toras, tábuas beneficiadas e pisos produzidos por hectare das amostras de madeira das florestas com 3 idade no Mato Grosso (9,5; 14,4 e 18,7 anos) e em Angatuba/SP com 9,4 anos de idade...78 


\section{LISTA DE TABELAS}

Tabela 1. Propriedades mecânicas de diversas espécies tropicais

Tabela 2. Informações gerais sobre os plantios de teca onde foram realizadas as coletas das amostras

Tabela 3. Dados climatológicos da região de Mirassol D’Oeste/MT das Fazendas Mutum e Santa Maria do Jauru; Jangada/MT da Fazenda Panflora e Angatuba/SP da Fazenda Santa Maria

Tabela 4. Especificações dos ensaios mecânicos, de propriedades físicas da madeira e programa de secagem drástica, caracterização anatômica e determinação do teor de extrativos ....................................................34

Tabela 5. Variáveis avaliadas no ensaio de secagem drástica a 100 C........................................................38

Tabela 6. Quantificação do escore atribuído aos defeitos de secagem ........................................................39

Tabela 7. Programa de secagem usado para secar as amostras de madeira a $8 \%$ de umidade..........................45

Tabela 8. Caracterização dos ensaios da qualidade dos pisos de teca ..........................................................47

Tabela 9. Variáveis dendrométricas calculadas nas toras de teca amostradas no Mato Grosso em diferentes idades (9,5; 14,4 e 18,7 aos) e em Angatuba/SP na idade de 9,4 anos e informações sobre o manejo de desbaste usado em cada tratamento

Tabela 10. Volumes individuais médios de medula, alburno, cerne e casca calculados nas toras de teca amostradas no Mato Grosso em diferentes idades (9,5; 14,4 e 18,7 anos) e em Angatuba/SP na idade de 9,4 anos

Tabela 11. Excentricidade da medula (\%) das toras de teca amostradas no Mato Grosso em diferentes idades $(9,5 ; 14,4$ e 18,7 anos) e em Angatuba/SP na idade de 9,4 anos . .55

Tabela 12. Densidade básica ( $\mathrm{g} \mathrm{cm}-3$ ) das amostras de toras de teca amostradas no Mato Grosso em diferentes idades (9,5; 14,4 e 18,7 anos) e em Angatuba/SP na idade de 9,4 anos

Tabela 13. Retratibilidade radial, tangencial, axial e volumétrica e coeficiente de anisotropia (T/R) das madeiras de teca coletadas na Fazenda Santa Maria no estado de São Paulo e nas Fazendas Mutum, Santa Maria do Jauru e Panflora no estado do Mato Grosso . .57

Tabela 14. Retratibilidade radial, tangencial e volumétrica e coeficiente de anisotropia (T/R) das madeiras de algumas espécies comerciais usadas para produção de pisos (Adaptado de Andrade, 2015), comparadas à média dos valores da teca desse estudo

Tabela 15. Comprimento, largura total, largura do lúme e espessura da parede das fibras da teca amostrada no Mato Grosso em diferentes idades (9,5; 14,4 e 18,7 anos) e em Angatuba/SP na idade de 9,4 anos.... 61

Tabela 16. Comprimento e largura dos vasos da teca amostrada no Mato Grosso em diferentes idades $(9,5 ; 14,4$ e 18,7 anos) e em Angatuba/SP na idade de 9,4 anos.

Tabela 17. Concentração de extrativos (\%) das amostras de madeira de teca coletadas no Mato Grosso em diferentes idades (9,5; 14,4 e 18,7 anos) e em Angatuba/SP na idade de 9,4 anos.....

Tabela 18. Resistência ao cisalhamento $12 \%$ das madeiras de teca coletadas na Fazenda Santa Maria no estado de São Paulo e nas Fazendas Mutum, Santa Maria do Jauru e Panflora no estado do Mato Grosso 65

Tabela 19. Resistência a compressão paralela $12 \%$ (RCO) das madeiras de teca coletadas na Fazenda Santa Maria no estado de São Paulo e nas Fazendas Mutum, Santa Maria do Jauru e Panflora no estado do Mato Grosso ..66

Tabela 20. Dureza das madeiras de teca coletadas na Fazenda Santa Maria no estado de São Paulo e nas Fazendas Mutum, Santa Maria do Jauru e Panflora no estado do Mato Grosso .... .68

Tabela 21. Flexão estática 12\% (MOR - Módulo de ruptura e MOE - Módulo de elasticidade) das madeiras de teca coletadas na Fazenda Santa Maria no estado de São Paulo e nas Fazendas Mutum, Santa Maria do Jauru e Panflora no estado do Mato Grosso...... 
Tabela 23. Coeficientes de correlação de Pearson entre densidade básica e as propriedades mecânicas da madeira de teca.

Tabela 24. Coeficientes de correlação de Pearson entre dimensões anatômicas das fibras e as propriedades mecânicas da madeira de teca

Tabela 25. Valores da umidade inicial (Ui) e das massas de água total (M1), com 30\% de umidade (M30) e com $5 \%$ de umidade (M5), para as amostras de teca do Mato Grosso em florestas de 3 idades (9,5; 14,4 e 18,7 anos) e em Angatuba com 9,4 anos de idade

Tabela 26. Valores de densidade básica e dos Índices de Rachaduras Internas e intensidade de colapso, para as amostras de teca do Mato Grosso em florestas de 3 idades $(9,5 ; 14,4$ e 18,7) e em Angatuba/SP com 9,4 anos de idade.

Tabela 27. Tempos de secagem (T1, T2 e T3) e taxas de secagem (V1, V2 e V3), para as amostras de teca do Mato Grosso em florestas de 3 idades (9,5; 14,4 e 18,7 anos) e em Angatuba/SP com 9,4 anos de idade

Tabela 28. Valores usados para a montagem dos programas de secagem ( $\mathrm{Ti}$, Tf e PS), com base nos resultados do ensaio de secagem a $100^{\circ} \mathrm{C}$ 75

Tabela 29. Rendimento volumétrico da produção de tábuas e pisos de Tectona grandis para as amostras de florestas do Mato Grosso e do estado de São Paulo

Tabela 30. Rendimento da produção de tábuas e pisos de Tectona grandis para as amostras de florestas com 3 idades no Mato Grosso (9,5; 14,41 e 18,7 anos) e em Angatuba/SP com 9,4 anos de idade

Tabela 31. Brilho (UB) para as amostras de teca do Mato Grosso em florestas de 3 idades $(9,5 ; 14,4$ e 18,7 anos) e em Angatuba/SP com 9,4 anos de idade

Tabela 32. Dureza (impacto de bola) para as amostras de teca do Mato Grosso em florestas de 3 idades $(9,5 ; 14,4$ e 18,7 anos) e em Angatuba/SP com 9,4 anos de idade

Tabela 33. Rugosidade para as amostras de teca do Mato Grosso em florestas de 3 idades $(9,5 ; 14,4$ e 18,7 anos) e em Angatuba/SP com 9,4 anos de idade..... 


\section{INTRODUÇÃO}

A teca (Tectona grandis L.f.) é uma espécie arbórea decídua, da floresta tropical, pertencente à família Lamiaceae, antigamente identificada como Verbenaceae, da Ordem Laminales (CANAL, 2017). Ocorre naturalmente distribuída em limitadas regiões do Sul e Sudeste Asiático. Segundo Tanaka et. al. (1998), a distribuição da teca é descontínua, cobrindo a Peninsula da India, Myanmar, norte e oeste da Tailândia e noroeste do Laos ao longo da divisa com o norte da Tailândia, assim como o centro e este de Java, onde a teca foi introduzida cerca de 400 a 600 anos atrás (KAOSA-ARD, 1983).

Segundo Higuchi (1979), a espécie é utilizada na construção de móveis e gabinetes, molduras, estruturas, pisos, pavimento de navios, construção de barcos, tornearias, chapas, postes de linha de transmissão, travessas para estradas de ferro e outros. Matricardi (1988), afirma que a teca é reconhecida como uma das espécies florestais mais importantes do mundo, devido às propriedades de sua madeira, tais como, resistência natural ao ataque de insetos e fungos; resistência mecânica; facilidade de secagem, serragem e beneficiamento; e características de acabamento, que a tornam muito valiosa no mercado internacional. Finger et al. (2001), ressaltou que nos países onde a teca é nativa seu uso é bem mais abrangente do que no Brasil ou outros países onde a árvore é plantada, incluindo o emprego generalizado da madeira de pequenos diâmetros proveniente dos desbastes e também de alburno.

No Brasil, os primeiros plantios comerciais de teca (Tectona grandis) foram estabelecidos na região de Cáceres, MT em 1971 pela atual Cáceres Florestal S/A. A partir dessas plantações iniciais, diversos outros investidores implantaram florestas incentivados pelo alto retorno financeiro da madeira, baseado em valores pagos pelo mercado internacional. Atualmente, existem no Brasil aproximadamente 88.000 hectares de áreas plantadas com teca (IBA, 2018), que representa um aumento de 35\% em relação à área plantada com essa espécie no ano de 2010. A área plantada no Brasil, comparativamente, é pequena, considerando os 2,5 milhões de hectares de florestas de teca existentes na Índia e 1,7 milhões de hectares explorados na Indonésia (ITTO, 2004).

O valor da madeira de teca pode chegar a US\$ 800.00 por metro cúbico (CIF, Porto na Índia), para toras de florestas plantadas com diâmetro acima de $35 \mathrm{~cm}$ (GLOBALWOOD, 2013). Entretanto, esses valores consideram madeira colhida no corte raso, ao final de 25 anos de idade da floresta. No Brasil, a madeira proveniente dos primeiros desbastes, normalmente, é vendida no mercado para uso como lenha, com valores da ordem de US\$5,00 por metro cúbico, o que não amortiza os custos de colheita, remoção e transporte da madeira. Esses desbastes iniciais geram um grande volume de madeira, que pode apresentar qualidade compatível para usos mais nobres, os quais são muito mais rentáveis.

Atualmente, tem-se utilizado a densidade populacional inicial entre 800 e 1.100 árvores por hectare em plantios de teca para que ocorra um desenvolvimento maior do diâmetro das árvores e o primeiro desbaste possa ser adiado. Ainda assim, a madeira proveniente do primeiro desbaste é utilizada como lenha, ou ainda, deixada na floresta para se evitar custos de remoção e transporte, o que encarece ainda mais a operação de colheita no desbaste. Isso ocorre em função de não haver informações da qualidade da madeira para usos específicos, o que impede a manufatura de produtos de maior valor agregado.

De uma maneira geral, e considerando a mesma espécie, os plantios florestais produzem madeira com propriedades físicas e mecânicas inferiores àquela obtida em florestas naturais. Da mesma forma, isso ocorre entre plantios jovens e mais velhos. As árvores de reflorestamento alcançam a época de colheita mais jovens do que as árvores de florestas nativas. O resultado é uma grande proporção de lenho juvenil e uma proporção menor de lenho adulto. Em caso do lenho juvenil não ser processado corretamente, sérios defeitos e falhas ocorrerão no produto final. 
Uma maneira de amenizar o problema, seria selecionar e reproduzir espécies que apresentem propriedades físicas e mecânicas similares entre árvores jovens, destinadas à desbaste, e árvores adultas, entre 25 e 30 anos, prontas para a colheita final.

Por outro lado, a utilização conjunta das madeiras de cerne e alburno numa mesma peça pode ser vista como uma solução necessária para obter-se bom aproveitamento, pois representa um maior volume utilizável das toras de desbastes. Porém, tais madeiras, por se caracterizarem como regiões anatômicas e fisiológicas diferentes, podem apresentar características físicas distintas, por exemplo, a densidade básica, supostamente maior no cerne. Por fim, devido a isso, questiona-se a qualidade desse material sob o receio de apresentar possíveis problemas na secagem e variações nos valores das propriedades mecânicas da madeira, as quais viriam afetar a qualidade do produto final.

O baixo aproveitamento da madeira de primeiro desbaste gera uma subestimação da lucratividade potencial dos reflorestamentos de teca. Dependendo do manejo utilizado em um povoamento de teca e da região onde foi efetuado o plantio, a floresta produzirá, entre o sexto ou oitavo ano, árvores com diâmetros que já viabilizarão a sua utilização. Desse modo, a madeira proveniente de desbastes em povoamentos bem conduzidos poderia ser utilizada na fabricação de diversos produtos de maior valor agregado. A princípio, baseando-se nos diâmetros das toras produzidas, pode-se indicá-las para móveis e gabinetes, pisos, forros, venezianas, molduras, estruturas, construção de barcos, tornearias e chapas (HIGUCHI, 1979). Destaca-se que a partir desse material mais jovem industrializado podem-se obter efeitos estéticos positivos, gerados pelo contraste entre o alburno e o cerne desta madeira, que são de tonalidades bem diferentes o que torna a distinção, entre as duas regiões, bem evidente, conforme pode ser observado na figura 1.

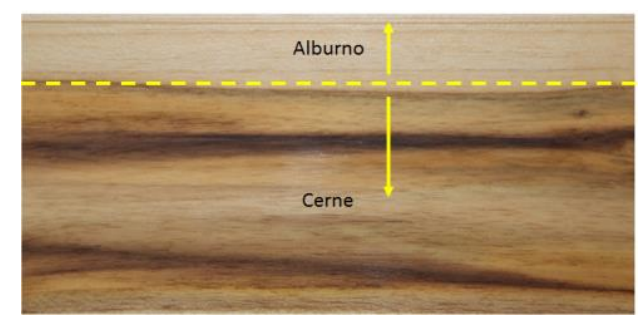

Figura 1. Piso de madeira maciça de teca obtida de árvore desbastada em plantio florestal de Angatuba/SP, aos 7,5 anos de idade

Diversos autores (FINGER, et. al., 2003; PINTO, 2007; BLANCO FLÓREZ, 2012 e CHAGAS, et. al. 2014) apresentaram resultados sobre as características físicas, anatômicas e as propriedades mecânicas da madeira de árvores de teca desbastadas em diferentes idades. Os resultados obtidos demonstraram que a qualidade da madeira retirada de desbastes com idades jovens dos povoamentos de teca, inclusive entre 5 e 7 anos, é muito boa, apresentando potencial de uso mais nobre do que a utilização atual que se dá para madeira dos plantios feitos no Brasil. Entretanto, nenhum desses trabalhos avaliou a qualidade de materiais acabados, por exemplo, pisos, produzidos por essa madeira.

Além da dureza, uma das características mais importantes da madeira para emprego em pisos é a sua estabilidade dimensional, considerando o inchamento e as retrações lineares e volumétrica, que ocorrem quando em serviço, e o fator anisotrópico. Para DURLO \& MARCHIORI (1992), citados por Motta et. al., 2014, o fator anisotrópico é o mais importante índice para se avaliar a estabilidade dimensional da madeira. Segundo os autores, para 
valores entre 1,2 e 1,5, a madeira é considerada excelente; valores entre 1,5 e 2,0, a madeira é considerada normal; e, acima de 2,0, a madeira é considerada ruim. Madeiras que apresentam elevada estabilidade dimensional podem ser utilizadas normalmente na fabricação de piso, esquadrias, portas e móveis. Porém, pisos manufaturados com madeiras que apresentam anisotropia maior do que 2,0 tendem a apresentar sérios problemas, frente a variações significativas de umidade do ar ou, ainda, com umedecimento involuntário do material. O inchamento excessivo da madeira acarreta o desencaixe das peças que se soltam e "pulam" acima da linha do contra-piso. A retração excessiva também leva ao desencaixe das peças, resultando no aparecimento de frestas.

Uma empresa fabricante de pisos de madeira maciça (Indusparquet Indústria e Comércio de Madeiras Ltda, localizada no município de Tietê, SP), realizou testes preliminares da qualidade da madeira de teca aos 7,5 anos de idade, proveniente de desbastes de um plantio estabelecido em Angatuba/SP. Os resultados mostraram que a madeira desse plantio apresentou boa estabilidade dimensional, potencializando seu uso na produção de pisos. Foram produzidos pisos maciços de $74 \mathrm{~mm}$ de largura e $19 \mathrm{~mm}$ de espessura (figura 1), resultando em boa aparência e acabamento final adequado. Testes definitivos da qualidade desse piso, inclusive em serviço, ainda não foram apresentados. Entretanto, os resultados iniciais foram promissores e justificam a continuidade dos estudos com esse tipo de madeira para a mencionada finalidade.

Assim, os objetivos gerais desse estudo foram determinar o potencial de uso da madeira de teca proveniente de desbastes para a finalidade de produção de piso e indicar os fatores de manejo da floresta que influenciaram sua melhor produtividade e qualidade.

Os objetivos específicos foram avaliar o comportamento dendrométrico de florestas de teca em diferentes idades, regiões e manejo; comparar as dimensões de seus elementos anatômicos; analisar as propriedades físicas e mecânicas da madeira e suas correlações; obter o rendimento do processo de produção de pisos por árvore e por área, determinando os índices de conversão de produção de toras para tábuas e de tábuas para pisos e comparar a qualidade dos pisos produzidos em diferentes condições climáticas, de manejo e idades da floresta. Foram elaborados programas de secagem simplificada para se avaliar possíveis diferenças entre tratamentos. 


\section{REVISÃO BIBLIOGRÁFICA}

\subsection{Descrição da espécie, região de origem e seus usos}

O gênero Tectona pertence à Família Botânica Lamiaceae, antiga Verbenaceae. Segundo Tropicos (2018), essa espécie pertence a Classe: Equisetopsida C. Agardh; Subclasse: Magnoliidae Novák ex Takht.; Superordem: Asteranae Takht.; Ordem: Lamiales Bromhead; Família: Lamiaceae Martinov; e Gênero: Tectona L.f. Além da Tectona grandis L.f., outras espécies desse gênero são Tectona hamiltoniana Wall., Tectona philippinensis Benth. \& Hook., Tectona ternifolia Buch.-Ham. ex Wall., e Tectona theka Lour.

A teca é uma árvore caducifólia com uma altura média e DAP (diâmetro à altura do peito) de 20 a 35 metros e 29 a $54 \mathrm{~cm}$ em 50 anos, respectivamente, muitas vezes estriada perto da base e de cor castanho claro e cinza (PALANISAMY et. al., 2009). Segundo Katwal (2005), a maior árvore de teca registrada encontra-se em Myanmar, na Reserva Florestal de Baw com 240 centímetros de DAP e 46 metros de altura e na Índia a maior árvore de teca apresenta 40 metros de altura e 210 centímetros de DAP, encontra-se em Parambikulam, Kerala. Tem sido relatado que a teca pode crescer até 500 anos (PALANISAMY et. al., 2009).

Segundo Palanisamy et. al. (2009), as folhas da teca são opostas, amplamente elípticas, obovadas, cerca de 30-70 cm de comprimento e 25-40 cm de largura, glabrescentes acima e estreladas-pubescentes abaixo, na base arredondada a aguda; no ápice obtuso a agudo, e de pecíolo robusto com 5-6 cm de comprimento. A árvore de teca lança suas folhas no verão, durante as chuvas e permanece sem folhas por alguns meses no ano, dependendo do clima local. As flores são de cor creme, pequenas e numerosas e formam inflorescências do tipo panícula. O fruto é uma drupa, com diâmetro de 1 a 2 centímetros, podendo conter até quatro sementes (CÁCERES FLORESTAL, 2006). O fruto é constituído por um caroço duro (endocarpo), revestido por um material de textura semelhante ao feltro (mesocarpo) e envolvido por uma membrana fina, inflada, de fácil remoção (exocarpo). O tronco é reto e revestido por casca espessa resistente ao fogo, possui alburno estreito e claro, bem distinto do cerne, cuja cor é marrom viva e brilhante (LIMA et. al., 2011).

A teca tem uma grande variedade de distribuição natural, ambientalmente diversificada e geograficamente separada, cobrindo partes da Índia, Myanmar, Tailândia e Laos (IUFRO, 2017). O limite dessa distribuição a norte é a latitude $25^{\circ} \mathrm{N}$ em Myanmar e o limite sul $9^{\circ} \mathrm{N}$ na Índia. Os limites longitudinais da teca são de $70^{\circ}$ a $100^{\circ} \mathrm{E}$. Dentro desta área, a ocorrência é descontínua, sendo as florestas naturais de teca separadas por cadeias montanhosas, planícies, terras agrícolas e outros tipos de florestas (RACHMAWATI et. al., 2002).

Segundo Tanaka et. al. (1998), a teca é uma espécie característica das florestas de monções, que se tornam parcialmente ou completamente sem folhas na estação seca. Diz, ainda, que a distribuição da teca não é idêntica com a área total desse tipo de clima, o que sugere que fatores edáficos controlem também a distribuição da teca nos trópicos, na sua área de origem, principalmente solos de má drenagem limitam o desenvolvimento da espécie. Mesmo assim, devido à sua dispersão geográfica e a variedade de ambientes onde ocorre naturalmente, a teca é uma espécie de alta adaptabilidade. Por isso têm sido estabelecidas plantações como espécie exótica para produção de madeira de alta qualidade em vários países fora da área de origem da espécie (PIMENTEL et. al., 2008 e BALL et. al., 1999).

As florestas naturais de teca estão em declínio, devido à super exploração, ao desmatamento e pela conversão da terra para outros usos. No entanto, a teca é uma das poucas espécies de madeira nobre que tem crescido cada vez mais em florestas plantadas em cerca de 70 países tropicais em toda a Ásia tropical, África, América Latina e Oceania (IUFRO, 2017). As florestas de teca plantadas, de acordo com várias estimativas, cobrem entre 4,35 e 6,89 
milhões de hectares. No Brasil, a área plantada com teca corresponde a 87,5 mil hectares e tem crescido mais de 5\% ao ano de 2.010 até 2.016 (figura 2).

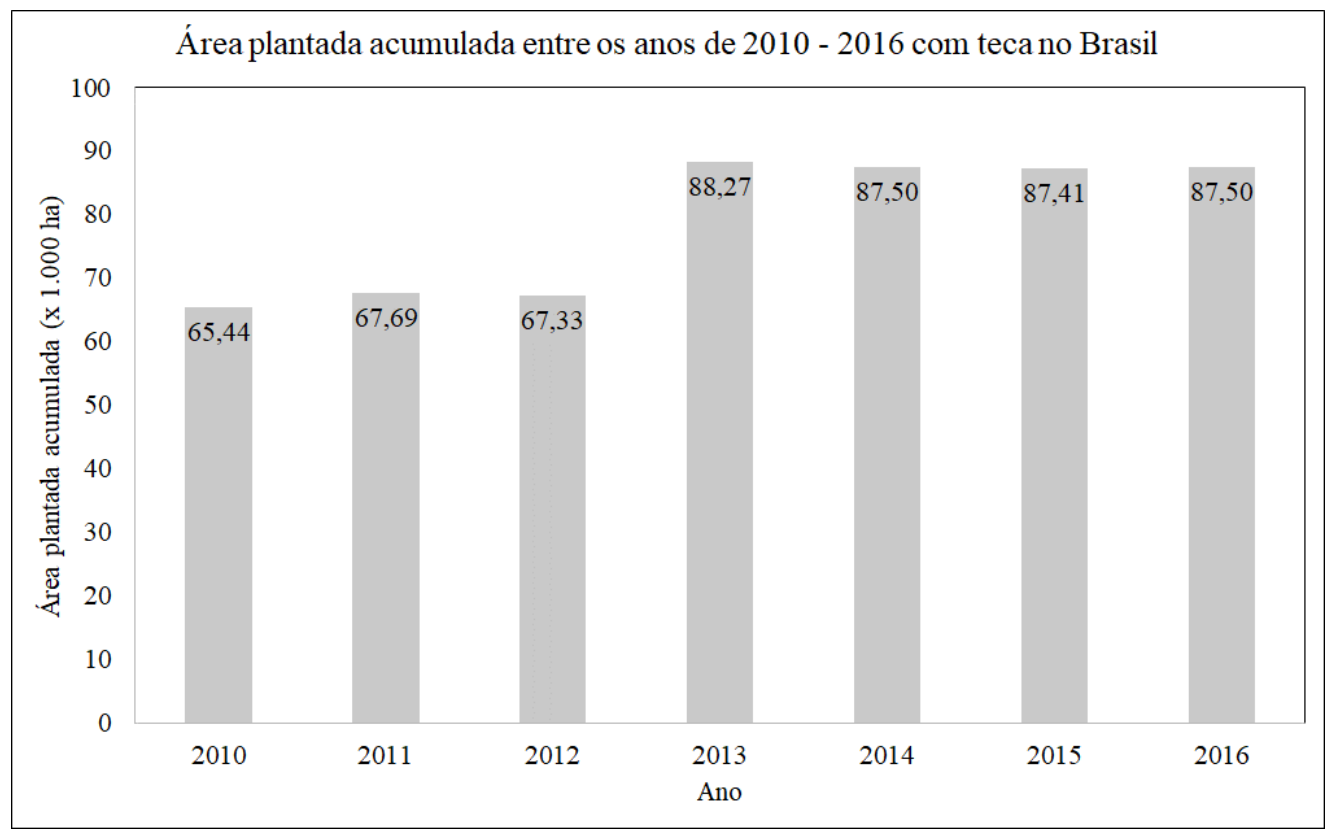

Figura 2. Área de teca plantada acumulada por ano no Brasil (2.010 - 2.016, fonte: (IBA, 2018)

A teca apresenta uma ampla variedade de usos, entre eles, mobiliário de qualidade, elementos estruturais, carpintaria, chapas, pisos e construção de "piers" e "decks" marinhos. Sua madeira tem sido usada na fabricação de pontes e pilares e, também, na construção de barcos. A madeira pode ser usada em ambientes úmidos e externos. Sua grande resistência a produtos químicos a torna ideal para móveis de laboratório (CAMINO \& MORALES, 2013).

A teca deve sua importância e valor tanto pelas propriedades físico-mecânicas desejáveis da madeira quanto pela sua robustez e desenvolvimento vigoroso. As principais características de sua madeira são: durabilidade, estabilidade, facilidade de pré-tratamento, resistência natural ao ataque de fungos, insetos, pragas e brocas. Desenho, cor e densidade são outros aspectos qualitativos importantes, além de baixa ocorrência de defeitos na tora. Devido a essas propriedades superiores, a teca é a madeira folhosa mais valorizada no mundo (VIEIRA et. al., 2008).

A idade de rotação dos plantios de teca em sua área de distribuição natural varia entre 50 e 90 anos (BALL et. al., 1999), com produtividades muito baixas. Na Indonésia, a média anual de incremento obtida em rotações entre 70 anos foi de 3,0 $\mathrm{m}^{3} \mathrm{ha}^{-1}$ ano $^{-1}$. Na América do Sul e Central, a expectativa para rotações de 20 a 25 anos é de 10 a 20 $\mathrm{m}^{3} \mathrm{ha}^{-1}$ ano $^{-1}$. Entretanto, plantios de teca em Rondônia, avaliados dendrometricamente por Vieira et. al. (2008), com 7 anos de idade, alcançaram volumes da ordem de $22 \mathrm{~m}^{3} \mathrm{ha}^{-1}$ ano ${ }^{-1}$. Em Tangará da Serra/MT, Cruz e. al. (2008) encontraram valor máximo de produtividade de teca de $30,82 \mathrm{~m}^{3} \mathrm{ha}^{-1} \mathrm{ano}^{-1}$, aos 5 anos de idade. Esse alto incremento médio anual de plantios em algumas regiões do Brasil, deve-se às condições climáticas adequadas para o desenvolvimento da espécie e do alto nível operacional dos plantios realizados no país.

A excelente reputação internacional da teca foi construída originalmente pela alta qualidade e durabilidade da madeira de florestas naturais. A maioria das florestas de teca plantadas não têm ainda uma imagem de alta qualidade no mercado internacional (IUFRO, 2017). 


\subsection{Características da madeira da teca}

\subsubsection{Propriedades físicas}

Segundo Thulasidas \& Bhat (2012), a teca tem sido identificada como uma das mais importantes espécies tropicais de madeira dura no mercado internacional para a produção de madeira de alta qualidade, a partir de plantações nos trópicos sob o manejo florestal sustentável. As suas propriedades físicas e mecânicas superiores, elevada durabilidade natural, estabilidade dimensional e estética a tornam adequada para uma variedade de utilizações finais, como construção pesada, mobiliário e armários, dormentes ferroviários, lâminas decorativas, carpintaria, construção naval e de carrocerias de caminhões, além de painéis reconstituídos de madeira.

A madeira da teca é excepcionalmente estável às mudanças em temperatura e umidade atmosféricas, não empena e se contrai pouco durante a secagem. A estabilidade dimensional permite que sua madeira resista à variação de umidade no ambiente (LIMA, 2011).

O cerne é definido como as camadas internas da madeira que, na árvore em crescimento, deixaram de conter as células vivas e nas quais os materiais de reserva (amidos) foram removidos ou convertidos em cerne. A quantidade de cerne varia consideravelmente com a idade, local e taxa de crescimento, e entre as árvores dentro do mesmo estande na mesma idade. Isto implica uma forte influência da idade celular, crescimento da árvore individual e forte herdabilidade genética (HILIS 1987, citado por TEWARI \& MARISWAMY, 2013). Em contraposição, o alburno, menos denso, constituído pelo conjunto das camadas externas do lenho, mais permeáveis a líquidos e gases está mais sujeito ao ataque de fungos apodrecedores e insetos, além de apresentar menor resistência mecânica (CALIL JR. et. al., 1998).

A proporção de cerne em árvores de teca é um fator importante no que diz respeito à qualidade da madeira. Durante o processo da formação do cerne certos processos químicos têm lugar, o que melhora a durabilidade e altera a cor da madeira (KOKUTSE et al., 2010). Um máximo de volume de cerne é desejável para a utilização final.

A proporção de cerne / alburno é uma característica importante da madeira. O alburno contém em média $120 \%$ de umidade, enquanto o cerne apresenta cerca de 40\%. Normalmente, é mais difícil remover a água do cerne do que do alburno e isso pode influenciar o programa de secagem necessário para diferentes espécies florestais (JOZSA \& MIDDLETON, 1994).

Kokutse et. al. (2010) estudaram os fatores que mais influenciam a distribuição de cerne no crescimento radial em plantações de teca. Esses autores concluíram que existe mais cerne por unidade de área em árvores dominantes. Essa conclusão reitera a importância dos desbastes aplicados em plantios de teca e de manejos em que o espaçamento inicial dos plantios seja maior, para que uma maior porcentagem de cerne seja formada na madeira. Além disso, a biomassa da folhagem na copa deve aumentar ao longo do tempo, a fim de sustentar o crescimento rápido do diâmetro do caule. Nesse estudo, verificaram que, as árvores dominantes tiveram a menor proporção de alburno, porque eram significativamente mais altas com hastes mais grossas do que as de outras classes, mas a largura e a conicidade do alburno foram semelhantes para todas as árvores.

Pérez \& Kanninen (2003) observaram que, em árvores de teca de 8 anos na Costa Rica, as de maior porte apresentavam maiores porcentagens e valores absolutos mais elevados de cerne do que árvores de pequeno porte. Tanto os valores absolutos quanto relativos foram significativamente correlacionados.

Arias (2003) destacou que a maioria das propriedades físicas da madeira produzida em rotações curtas difere pouco da gerada por plantações maduras ou teca cultivada naturalmente. Segundo esse autor, as principais diferenças 
foram relacionadas à durabilidade natural e frequência de defeitos, como nós e troncos curvos. O principal fator limitante para a utilização de teca jovem pode ser o diâmetro do caule relativamente pequeno. No entanto, novas tecnologias para o processamento de madeira devem permitir uma melhor utilização de toras de pequeno diâmetro ao longo do tempo. O autor indica um exemplo na Costa Rica, onde algumas empresas privadas estão empregando novas tecnologias para processar madeira juvenil de segundo e terceiro desbastes (mínimo de 12-14 cm de diâmetro, com casca) para produzir pisos e móveis. Na maioria dos países, a madeira proveniente de desbastes de plantações com longos períodos de rotação tem sido usada em postes, lenha e outros produtos de menor valor.

Segundo Szücs et. al. (2015), entre as características físicas da madeira, cujo conhecimento é importante para sua utilização como material de construção, destacam-se: umidade; densidade; retratibilidade; resistência ao fogo; durabilidade natural; e resistência química.

A estrutura anatômica influencia diretamente na densidade da madeira, e esta última, por sua vez, também exerce influência diretamente na anisotropia (BATISTA et. al., 2010). A anisotropia é definida como um comportamento desigual nas diferentes direções estruturais da madeira, longitudinal, tangencial e radial. A maior variação dimensional ocorre na direção tangencial aos anéis de crescimento e a contração radial é menor do que a tangencial.

Dentre as diversas propriedades da madeira, a densidade é a mais utilizada, pela facilidade de ser determinada e por se correlacionar diretamente com as propriedades físicas e mecânicas da madeira e com a composição celular. E, todas, são afetadas pela umidade (FINGER et. al., 2003).

\subsubsection{Elementos anatômicos}

Considerando que o conhecimento da produtividade de T. grandis, seja relevante para a recomendação de cultivo é importante estudar as dimensões das fibras desta madeira, como um dos parâmetros de avaliação tecnológica da espécie. Lima (2011) sugere que há diferença nas dimensões anatômicas da teca em diferentes espaçamentos inicias do plantio, sendo que, o comprimento e a parede das fibras são maiores e a frequência dos vasos é menor, produzindo madeira de maior densidade básica em espaçamentos iniciais mais largos.

Em lenhos de angiospermas dicotiledôneas são encontrados os seguintes elementos estruturais (BURGER \& RICHTER, 1991):

“Vasos: São estruturas que ocorrem em quase todas as angiospermas e constituem o principal elemento de diferenciação entre estas e as gimnospermas. Vaso é um conjunto normalmente axial de células sobrepostas (elementos vasculares), formando uma estrutura tubiforme contínua, que tem por função a condução ascendente de líquidos na árvore. Para permitir a circulação de substâncias líquidas, os elementos vasculares possuem extremidades perfuradas denominadas placas de perfuração. Além disso, os vasos apresentam pontoações em suas paredes laterais para comunicação com as células vizinhas.

Na seção transversal, a distribuição dos vasos, sua abundância, tamanho e agrupamentos são características importantes para as propriedades tecnológicas da madeira.

Parênquima axial: Desempenha função de armazenamento no lenho. A abundância de parênquima confere as madeiras leveza, baixa resistência mecânica e pouca durabilidade natural.

Fibras: São células que geralmente constituem a maior porcentagem do lenho e sua função é a sustentação. Sua porção no volume total e a espessura de suas paredes influem diretamente na massa específica e no grau de alteração volumétrica e indiretamente nas propriedades mecânicas da madeira. 
Parênquima transversal (raios): Desempenham as funções de armazenamento, transformação e condução transversal de substâncias nutritivas."

Segundo Moya, et. al. (2009), as dimensões das fibras que compõem a madeira, em geral são pouco afetadas pela procedência das árvores ou pela qualidade dos sítios em que as florestas foram plantadas.

\subsubsection{Teores de extrativos na madeira de teca}

A propriedade intrínseca da madeira da teca que a distingue das outras madeiras é devido a presença de vários elementos extrativos ativos incrustados na parede celular. Alguns desses extrativos atuam contra cupins e fungos; outros têm propriedades hidrofóbicas (PREMRASMI \& DIETRICHS, 1967).

Os extrativos são frequentemente responsáveis por determinadas características da madeira como: cor, cheiro, resistência natural ao apodrecimento, gosto e propriedades abrasivas. Sua composição e quantidade relativa dependem de diversos fatores, como espécie, idade e região de procedência, etc. Aproximadamente de 3 - 10\% da madeira seca é constituída de extrativos sendo que, geralmente para as madeiras de coníferas esse teor fica na faixa de 5 - $8 \%$ e para as folhosas de regiões temperadas na faixa de 2 - 4\%, podendo chegar a valores superiores a $10 \%$ na madeira de espécies de regiões tropicais (KLOCK \& ANDRADE, 2013).

Todos os compostos formados na madeira originam-se da fotossíntese. Os extrativos são resultados de modificações sofridas pelos carboidratos no processo fisiológico da árvore. Os locais de formação e posterior deslocamento para um local definitivo na madeira dependem da função do extrativo. Se o extrativo consiste numa substância de reserva, seu teor atinge um valor máximo pouco antes de se iniciar a estação desfavorável e passa pelo seu mínimo ao final desta estação (KLOCK \& ANDRADE, 2013).

Os teores de extrativos na madeira de teca são extremamente importantes, porque definem a qualidade estética e a durabilidade desse material (GARCIA \& MARINONIO, 2016). Segundo esses autores, os teores de extrativos estão altamente correlacionados com a presença de cerne e a cor da madeira e são afetados pelo manejo da floresta, como espaçamento e desbastes. Os extrativos também podem afetar a densidade da madeira e são responsáveis pela resistência à degradação fúngica. $\mathrm{O}$ teor de extrativos da madeira de teca aumenta com a idade da árvore e a presença de substâncias do tipo tectoquinona está relacionada à maior durabilidade natural (GARCIA \& MARINONIO, 2016). Entretanto Thulasidas \& Bhat (2012) indicam que a maior resistência à deterioração da madeira de teca em regiões secas está principalmente associada à maior quantidade de napthoquinona, ao invés de estarem relacionadas ao conteúdo extrativo total ou de tectoquinona.

Uma característica importante da madeira de teca, que lhe confere grande durabilidade em seu uso é o teor de extrativos encontrado, principalmente no cerne, que apresenta alta durabilidade natural e excelente estabilidade dimensional. As principais substâncias encontradas são o caucho, a tecnona, lapachol e tectol + desidrotectol (PREMRASMI \& DIETRICHS, 1967).

Os extrativos também contêm um grande número de compostos fenólicos, alguns deles, resíduos e subprodutos da biossíntese da lignina sendo, portanto, compostos heterogêneos (KLOCK \& ANDRADE, 2013). As substâncias fenólicas são encontradas em quantidades pequenas no xilema e se concentram principalmente no cerne da madeira, embora possam estar presentes também no alburno. Apresentam propriedades fungicidas, protegendo a madeira contra a biodegradação. 
Thulasidas \& Bhat (2012) encontraram resultados mostrando que o clima (seco ou úmido) pode afetar os teores totais de extrativos na madeira de teca, sendo maior em local úmido. A quantidade de tectonina na madeira acompanhou a mesma tendência do resultado apresentado para teores totais de extrativos.

\subsubsection{Propriedades mecânicas da madeira de teca}

As propriedades mecânicas são as responsáveis pela resposta da madeira quando solicitada por forças externas. São divididas em propriedades de resistência, quando o material é solicitado por uma força e elasticidade, que é a capacidade do material retornar à sua forma inicial (CALIL JR. et. al., 1998).

Andrade (2015) realizou uma avaliação das propriedades mecânicas de diversas espécies tropicais, algumas já comerciais e outras potenciais para uso como piso e os resultados estão apresentados na tabela 1.

Tabela 1. Propriedades mecânicas de diversas espécies tropicais

\begin{tabular}{|c|c|c|c|c|c|c|c|}
\hline \multirow{3}{*}{ Espécie } & \multirow{3}{*}{ Nome comum } & \multirow{3}{*}{ Nome científico } & \multicolumn{2}{|c|}{ Flexão Estática } & \multirow{2}{*}{$\begin{array}{c}\text { Compressão } \\
\text { paralela }\end{array}$} & \multirow{2}{*}{ Cisalhamento } & \multirow{3}{*}{$\begin{array}{c}\text { Dureza* } \\
\text { kgf }\end{array}$} \\
\hline & & & MOR & MOE & & & \\
\hline & & & \multicolumn{4}{|c|}{ kgf $\mathrm{cm}^{-2}$} & \\
\hline \multirow{13}{*}{ Potenciais } & Angelim-vermelho & Dinizia excelsa & 1.464 & 146.230 & 796 & 157 & 1.468 \\
\hline & Castanha-sapucaia & Lecythis pisonis & 1.310 & 129.973 & 643 & 151 & 1.189 \\
\hline & Cedrinho & Erisma uncinatum & 864 & 104.146 & 504 & 86 & 525 \\
\hline & Cupiúba & Goupia glabra & 1.217 & 121.613 & 670 & 134 & 824 \\
\hline & Itaúba-amarela & Mezilaurus itauba & 1.263 & 137.675 & 687 & 118 & 713 \\
\hline & Jarana-amarela & Lecythis poiteaui & 1.360 & 150.595 & 720 & 187 & 1.403 \\
\hline & Mandioqueira & Qualea paraenses & 1.201 & 140.100 & 653 & 133 & 758 \\
\hline & Maparajuba & Manilkara bidentata & 1.357 & 135.854 & 696 & 131 & 986 \\
\hline & Pequiá & Caryocar villosum & 1.074 & 111.949 & 517 & 142 & 832 \\
\hline & Sucupira-preta & Bowdichia nitida & 1.694 & 163.380 & 934 & 175 & 1.312 \\
\hline & Tachi-preto & Tachigali myrmecophila & 1.167 & 122.481 & 620 & 142 & 781 \\
\hline & Tanibuca & Terminalia amazonica & 1.407 & 140.028 & 763 & 163 & 1.277 \\
\hline & Timborana & Piptadenia gonoacantha & 1.250 & 133.956 & 757 & 153 & 881 \\
\hline \multirow{13}{*}{ Comerciais } & Amendoim & Pterogyne nitens & 1.109 & 124.511 & 540 & $126^{* *}$ & $608 * *$ \\
\hline & Cabreúva-vermelha & Myroxylum balsamum & $1.352 * * *$ & $127.800 * *$ & $725 * * *$ & $184 * *$ & $1.034^{* *}$ \\
\hline & Cumaru & Dipteryx odorata & 1.663 & 158.000 & 1.086 & 161 & 1.601 \\
\hline & Garapa & Apuleia leiocarpa & 1.272 & 129.000 & 644 & 131 & 845 \\
\hline & Guaiuvira & Cordia americana & $1.360 * * *$ & 124.230 & - & 163 & - \\
\hline & Ipê & Handroanthus serratifolius & 1.726 & 131.000 & 869 & 137 & 1.406 \\
\hline & Jatobá & Hymenaea courbaril & 1.399 & 159.000 & 773 & 194 & 1.116 \\
\hline & Maçaranduba & Manilkara huberi & 1.797 & 174.000 & 1.109 & 171 & 1.382 \\
\hline & Muiracatiara & Astronium lecointei & 1.391 & 153.000 & 840 & 171 & 883 \\
\hline & Peroba-de-campos & Paratecoma peroba & $1.186^{* * * *}$ & $105.300^{* *}$ & $551 * * *$ & $119 * *$ & $724 * *$ \\
\hline & Peroba-mica & Aspidosperma macrocarpon & 1.390 & 141.000 & 664 & 151 & 840 \\
\hline & Tatajuba & Bagassa guianensis & 1.269 & 118.000 & 801 & 128 & 753 \\
\hline & Tauari & Couratari oblongifolia & 847 & 111.000 & 455 & 106 & 469 \\
\hline
\end{tabular}

Fonte: Adaptado de Andrade (2015). Dureza*: valor médio do plano transversal

** Valores com a madeira verde. *** Valores com a madeira a $15 \%$

A madeira pode sofrer solicitações de compressão, tração, cisalhamento e flexão. Ela tem resistências com valores diferentes conforme variar a direção da solicitação em relação às fibras e também em função do tipo de 
solicitação. Isso significa que, mesmo mantida uma direção segundo as fibras, a resistência à tração é diferente da resistência à compressão (SÜCS et. al., 2015).

\subsubsection{Resistência ao cisalhamento}

Existem três tipos de cisalhamento que podem ocorrer em peças de madeira. O primeiro se dá quando a ação age no sentido perpendicular às fibras (cisalhamento vertical), este tipo de solicitação não é crítico na madeira, pois, antes de romper por cisalhamento a peça já apresentará problemas de resistência na compressão normal. Os outros dois tipos de cisalhamento referem-se à força aplicada no sentido longitudinal às fibras (cisalhamento horizontal) e à força aplicada perpendicular às linhas dos anéis de crescimento (cisalhamento "rolling"). O caso mais crítico é o do cisalhamento horizontal que leva à ruptura pelo escorregamento entre as células de madeira. Já o cisalhamento "rolling" produz uma tendência de as células rolarem umas sobre as outras (CALIL JR. et. al., 1998).

Josue \& Imiyabir (2011), encontraram resultados de resistência ao cisalhamento da madeira de teca aos 15 anos maior do que valores obtidos na literatura. A comparação desse trabalho foi realizada com Keating \& Bolza (1982) para regiões úmidas e Soerianegara \& Lemmens (1993), que avaliaram esses resultados em regiões secas.

Pinto (2007) encontrou variação da resistência ao cisalhamento entre plantios com diferentes idades, apenas em plantios mais velhos, provavelmente com uma maior formação de madeira madura em relação à juvenil. Não houve diferença entre as populações mais novas, com 5 e 10 anos, sendo essa tendência acompanhada pelo comportamento da densidade básica. Nesse caso, a massa específica básica dos plantios mais novos foram de 0,53 e 0,55 $\mathrm{g} \mathrm{cm}^{-3}$, enquanto que no plantio de 30 anos foi de $0,66 \mathrm{~g} \mathrm{~cm}^{-3}$.

\subsubsection{Resistência a compressão paralela às fibras}

A compressão na madeira pode ocorrer segundo três orientações: paralela, normal e inclinada em relação às fibras. Quando a peça é solicitada por compressão paralela às fibras, as forças agem paralelamente ao comprimento das células. As células reagindo em conjunto conferem uma grande resistência da madeira à compressão (SZÜCS et. al., 2015).

Thulasidas \& Bhat (2012) encontraram maiores valores de resistência a compressão paralela em teca de 35 anos de idade em regiões de clima mais seco, comparado com áreas úmidas. Nesse caso, houve também correlação positiva e significativa entre a densidade básica e a compressão paralela.

Bhat (1998), citado por Thulasidas \& Baillères (2017), revela que as árvores selecionadas para crescimento rápido em plantios florestais de diferentes idades (13, 21, 55 e 65 anos) apresentam diferenças não significativas em relação às propriedades de densidade e resistência, módulo de elasticidade (MOE), módulo de ruptura (MOR) e resistência máxima a compressão (MCS).

\subsubsection{Dureza}

Segundo Soler (2014), a dureza é definida como a resistência requerida para um corpo sólido penetrar em outro por meio de esforço. 
A dureza Janka, embora seja propriedade mecânica sem aplicação imediata ou direta dos seus resultados, subsiste como propriedade de real importância na caracterização mecânica de madeiras por ser importante parâmetro de comparação entre espécies (COLENCI, 2002). Ainda, segundo esse autor, a dureza Janka apresenta boas correlações com outras importantes propriedades mecânicas da madeira como, por exemplo, a compressão paralela e normal às fibras.

A dureza pode ser influenciada pelos teores de extrativos, que são responsáveis pela resistência ao apodrecimento da madeira e ataque de insetos (PETTERSEN, 1984).

\subsubsection{Flexão Estática}

A ruptura em peças solicitadas à flexão ocorre com a formação de minúsculas falhas de compressão seguidas pelo esmagamento macroscópico na região comprimida. Este fenômeno gera o aumento da área comprimida na seção e a redução da área tracionada, causando acréscimo de tensões nesta região, podendo romper por tração (SZÜCS et. al., 2015).

Segundo Bhat (2003) a rigidez média da madeira (módulo de elasticidade - MOE) e o esforço de flexão (módulo de ruptura MOR) na madeira juvenil são 85\% e 82\%, respectivamente, do valor da madeira madura. Portanto, a relação entre madeira madura e juvenil na árvore é importante para a flexão estática, que é uma das propriedades mecânicas importantes para a qualificação e uso da madeira.

Polato et. al. (2005) sugerem que os valores de flexão estática (MOR e MOE) referentes à madeira já madura, tal qual as de florestas de longa rotação, são similares a florestas de curta rotação com idades de 14 e 22 anos de idade.

\subsection{Secagem da madeira}

A madeira apresenta a água dentro de sua estrutura nas formas líquida e gasosa (vapor). Detalhando as formas de água líquida, pode-se dizer que existem a água de capilaridade nos espaços da estrutura da madeira e a água de impregnação ou higroscópica, que está impregnada nas cadeias de celulose da parede celular (KEINE, 1997).

A secagem é necessária para a madeira ser usada na maioria dos produtos. Madeira seca tem muitas vantagens sobre a madeira verde para produtores e consumidores. A remoção do excesso de água reduz o peso e, portanto, os custos de transporte e manuseio. A secagem apropriada limita a retratibilidade e o inchaço da madeira em uso a quantidades administráveis sob todas as condições extremas de umidade relativa ou inundação. À medida que a madeira seca, a maioria de suas propriedades de resistência aumentam, assim como suas propriedades isolantes elétricas e térmicas. Madeira devidamente seca pode ser cortada com precisão e usinada de forma mais fácil e eficiente. Pintura, verniz e outros acabamentos são aplicados e mantidos de forma mais eficaz. A madeira deve estar relativamente seca antes de ser colada ou tratada com produtos químicos que evitam a deterioração e retardam o fogo. O teor recomendado de umidade da madeira, em peças como piso, deve ser o mais próximo possível das condições de equilíbrio de umidade (EMC) em serviço (SIMPSON, 1999).

Segundo Galvão \& Jankowsky (1985), citado por Jankowsky (2009), a água da madeira encontra-se de duas formas: água livre ou capilar, localizada nos lumes e possíveis espaços intercelulares. Ela está em estado líquido e fica 
retida no interior da madeira por forças capilares; água higroscópica ou de impregnação, que é encontrada no interior da parede celular e em todos os elementos anatômicos da madeira. São moléculas de água que estão ligadas em camadas polimoleculares, principalmente por pontes de hidrogênio, aos grupos hidroxílicos acessíveis nas regiões não cristalinas da parede celular.

A estrutura anatômica da madeira pode ser analisada como um feixe de capilares (tubos de diâmetro reduzido), interligados entre si através das pontoações. Quando a madeira serrada é exposta ao ar, a água presente nas fibras superficiais também entra em contato com o ar. Por consequência, surge uma interface líquido/gás (água livre/ar) no interior das fibras superficiais, originando a tensão capilar, que força o movimento da água líquida até a superfície de evaporação (JANKOWSKY, 2009). Na medida em que a água livre evapora, a superfície de evaporação desloca-se em direção ao centro da peça; e o menisco formado na interface água/ar irá ocupar as pontoações. Uma vez que o diâmetro interno da pontoação é muito menor do que o diâmetro da fibra, a tensão capilar atingirá seu valor máximo.

Como a movimentação da água higroscópica só ocorre abaixo do PSF (ponto de saturação das fibras), a água livre que estava presente no lume das fibras foi substituída por ar. Nessa situação, ocorrerá conjuntamente a difusão da água higroscópica através das paredes e de vapor d'água no interior dos lumes; caracterizando o transporte de massa conhecido como transporte em estado-instável (GALVÃO \& JANKOWSKY, 1985, citado por JANKOWSKY, 2009).

O programa de secagem é uma série de temperaturas e umidades relativas que são aplicados nos vários estágios da secagem. $\mathrm{Na}$ maioria dos programas, a temperatura aumenta gradativamente, enquanto a umidade relativa decresce (SIMPSON, 1999).

O programa de secagem adequado é importante para que as tensões de secagem não excedam a resistência da madeira em qualquer temperatura e umidade, senão a madeira rachará na superfície ou internamente, ou será esmagada por forças que colapsam as células da madeira (SIMPSON, 1999). Programas específicos de secagem têm sido desenvolvidos para controlar a temperatura e a umidade relativa de acordo com o conteúdo de umidade e a situação de tensão dentro da madeira, minimizando potenciais defeitos que podem ser causados pela retração.

Segundo Eleotério \& Kirchheim da Silva, 2012, o método da secagem drástica se baseia no princípio de que pequenas amostras de madeira, quando expostas aos efeitos de secagem drástica em estufa a $100^{\circ} \mathrm{C}$, proporcionam um comportamento semelhante na secagem convencional. O método foi baseado nas recomendações e metodologias apresentadas por Jankowsky (2009). Comparando diversos métodos de secagem Eleotério \& Kirchheim da Silva, 2012, determinaram que os potenciais de secagem obtidos através da secagem drástica foram os mais próximos aos recomendados pela maioria dos autores para secagem de Cumaru, Jatobá e Muiracatiara.

Jankowsky, 2009 concluiu que os programas estimados pelo método de secagem a $100^{\circ} \mathrm{C}$ são mais suaves do que os estimados pelo método de estimativa de secagem usando a densidade específica, o que aumenta a segurança na indicação desses programas em escala industrial. Outro aspecto favorável ao método de secagem drástica é a medição das taxas de secagem e da possibilidade da incidência de defeitos, que refinam o grupamento de espécies para um mesmo programa de secagem. 


\subsection{Produção de pisos de madeira}

Chaix et. al. (2007) consideram algumas características tecnológicas importantes para produção de assoalhos e parquetes de madeira. São elas: estética (relativo ao desenho, cor, granulometria e estrutura); estabilidade dimensional; durabilidade natural; densidade básica e porcentagem de alburno. A cor e a estrutura da madeira normalmente são definidas pelo mercado consumidor. A estabilidade dimensional é um dos fatores mais importantes, pois determinam uma característica fundamental na instalação de pisos em locais com variações muito significativas de temperatura e umidade. A durabilidade natural determina o local de uso, sendo o uso externo para madeira de maior durabilidade e uso interno, no caso de material de menor durabilidade. Já a densidade básica, além de estar relacionada às propriedades mecânicas da madeira, também determina a dureza do material. A porcentagem de alburno está ligada direta e inversamente a durabilidade, pois o cerne se correlaciona com os teores de extrativos, que são importantes na durabilidade da madeira.

$\mathrm{Na}$ indústria de móveis e pisos a aparência superficial da madeira também é muito importante na determinação da sua qualidade para a utilização final. Padrões de cores e desenhos são muito procurados nesses ramos, devido às tendências e modismos que tornam o visual do material um fator determinante na escolha de uma espécie (SOLER, 2014).

Madeira serrada de espécies nativas ou de plantios florestais é a matéria-prima para a produção de pisos maciços. A tábua recebida, se estiver úmida, é gradeada e passa pelo processo de secagem para se adequar ao valor estipulado pelo mercado interno ou externo. Na próxima fase, as tábuas são aplainadas nas quatro faces (S4S “SurfaceFour-Side") para o ajuste da largura e espessura da peça e em seguida são otimizadas, onde as réguas são destopadas em comprimentos padrões e os defeitos da madeira são retirados. Então, a próxima etapa é a usinagem, onde se confeccionam o encaixe macho e fêmea nas laterais e no topo. Também pode ser feito o bisotê, que é um chanfro nas extremidades do espelho do piso. Depois, há outra classificação na qual as réguas com defeitos da usinagem são retiradas. Por fim, o acabamento, onde o piso passa pela linha de verniz (SOLER, 2014). 


\section{MATERIAL E MÉTODOS}

\subsection{Localização da área de estudo}

O material para o desenvolvimento do estudo foi proveniente de plantios de Tectona grandis L. f., estabelecidos no estado do Mato Grosso, com idades aproximadas de 9,5; 14,4 e 18,7 anos (figura 3 e tabela 2). Também, foram amostradas árvores em um plantio de teca com 9,4 anos de idade implantado em Angatuba/SP.

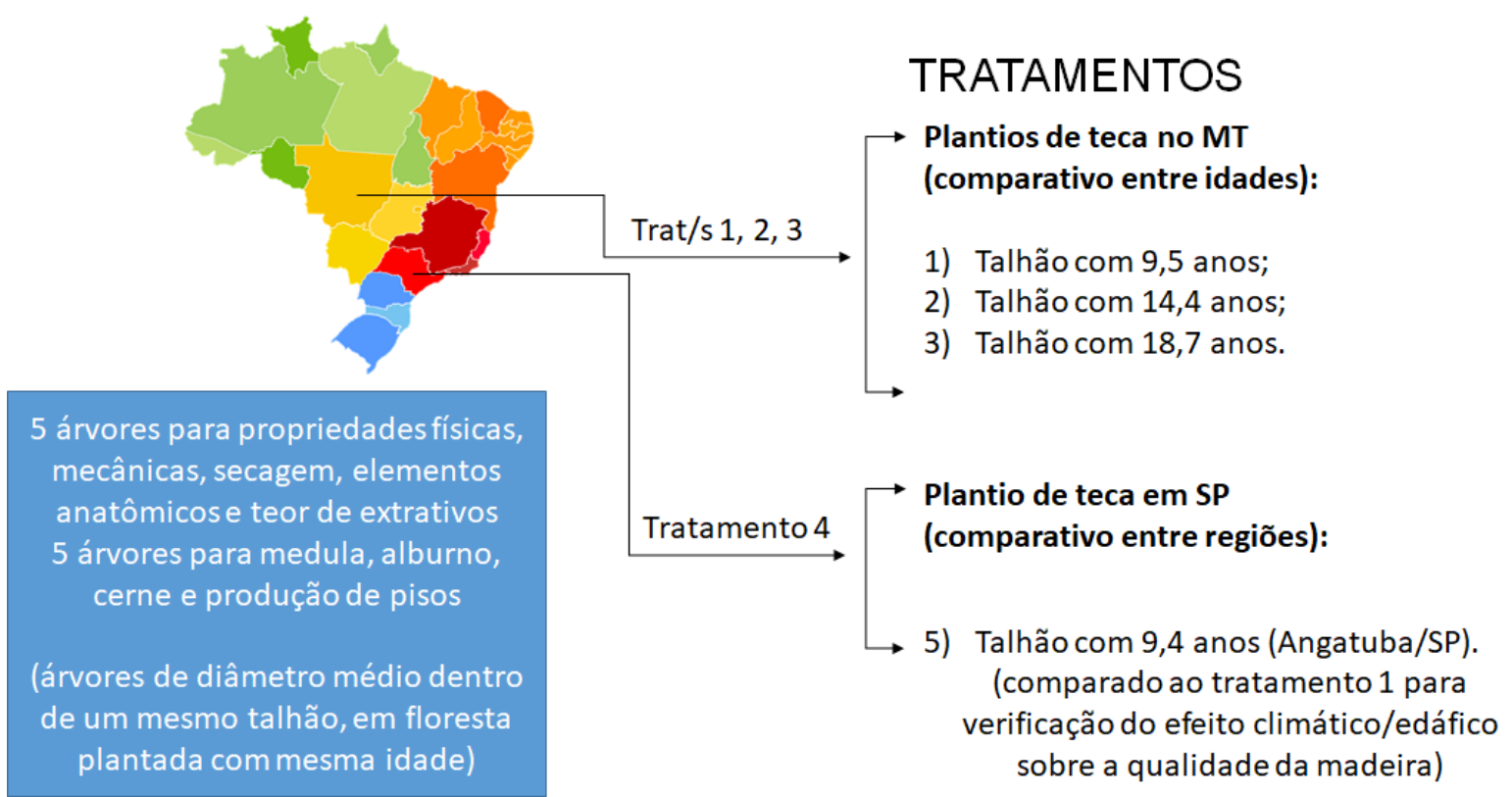

Figura 3. Localização das áreas a serem estudadas

Os plantios da Fazenda Mutum e da Fazenda Santa Maria do Jauru encontram-se, respectivamente, nos municípios de Glória D’Oeste/MT e Porto Espiridião/MT. O clima dessa região é tropical sub-úmido. De acordo com Köppen \& Geiger a classificação do clima é Aw. A temperatura média da região é de $25,4{ }^{\circ} \mathrm{C}$ e a pluviosidade média anual é de $1.457 \mathrm{~mm}$. O mês mais seco, julho, apresenta a menor precipitação que é de $16 \mathrm{~mm}$. Já o mês de janeiro, com média de $274 \mathrm{~mm}$, apresenta a maior precipitação (tabela 3).

Tabela 2. Informações gerais sobre os plantios de teca onde foram realizadas as coletas das amostras

\begin{tabular}{lcccc}
\hline \multicolumn{1}{c}{ Fazenda } & Município & $\begin{array}{c}\text { Espaçamento inicial } \\
(\text { metros })\end{array}$ & $\begin{array}{c}\text { Densidade } \\
\left.\text { (árvore ha }^{-1}\right)\end{array}$ & $\begin{array}{c}\text { Idade } \\
(\mathbf{a n o s})\end{array}$ \\
\hline Mutum & Glória D’Oeste/MT & $4 \times 3$ & 833 & 9,5 \\
\hline Santa Maria do Jauru & Porto Espiridião/MT & $3 \times 3$ & 1.111 & 14,4 \\
\hline Panflora & Rosário D’Oeste/MT & $3 \times 3$ & 1.111 & 18,7 \\
\hline Santa Maria & Angatuba/SP & $3 \times 2$ & 1.667 & 9,4 \\
\hline
\end{tabular}


O clima na região da Fazenda Panflora é tropical sub-úmido. Segundo Köppen \& Geiger a classificação do clima é Aw. Há muito mais pluviosidade no verão que no inverno e a temperatura média é de $24,3{ }^{\circ} \mathrm{C}$. A média anual de pluviosidade é de 1.236 mm. O mês mais seco é julho com 24 mm e o mês de março é o mês com maior precipitação, apresentando uma média de $173 \mathrm{~mm}$ (tabela 3).

O plantio de Angatuba/SP, nas coordenadas $23^{\circ} 22^{\prime} 58.42^{\prime \prime S}$ e $48^{\circ} 33^{\prime} 39.17^{\prime \prime W}$, encontra-se em região de clima subtropical, com temperatura média de $19,9^{\circ} \mathrm{C}$ e $1.215 \mathrm{~mm}$ de pluviosidade média anual. O clima é classificado como Cwa segundo Köppen \& Geiger. Em Angatuba existe uma pluviosidade significativa ao longo do ano. Mesmo o mês mais seco apresenta alguma pluviosidade, valor médio de $38 \mathrm{~mm}$ (tabela 3), já o mês mais chuvoso, que é janeiro, atinge em média $195 \mathrm{~mm}$. Esse plantio foi estabelecido em 15 de novembro de 2.007.

O solo da Fazenda de Angatuba/SP é um Latossolo Vermelho-Amarelo/Vermelho Distrófico Típico, A Moderado, Textura média, álico + Neossolo Quartzarênico Órtico Típico (INSTITUTO FLORESTAL, 2017). As fazendas do Mato Grosso apresentam os seguintes solos: Fazenda Panflora, solo concrecionário câmbico álico; Mutum, Latossolo Vermelho-Escuro Eutrófico e Santa Maria do Jauru, Podzólico Vermelho-Amarelo Distrófico. O perfil do solo das Fazendas Santa Maria do Jauru e Panflora apresentam em comum uma camada que limita a drenagem, o que não ocorre na Fazenda Mutum e na Fazenda Santa Maria do estado de São Paulo. No caso da Fazenda Panflora, de 18,7 anos, as limitações são influenciadas por concreções de óxido de ferro. Já, na Fazenda Santa Maria do Jauru, essas limitações são determinadas por rochas de quartzo. 
Tabela 3. Dados climatológicos da região de Mirassol D’Oeste/MT das Fazendas Mutum e Santa Maria do Jauru; Jangada/MT da Fazenda Panflora e Angatuba/SP da Fazenda Santa Maria. Fonte: Climate-data.org (2018)

REGIÃO DE MIRASSOL D’OESTE/MT

\begin{tabular}{|c|c|c|c|c|c|c|c|c|c|c|c|c|}
\hline \multirow{2}{*}{ Parâmetros } & \multicolumn{12}{|c|}{ MESES } \\
\hline & Jan & Fev & Mar & Abr & Mai & Jun & Jul & Ago & Set & Out & Nov & Dez \\
\hline Temperatura média $\left({ }^{\circ} \mathrm{C}\right)$ & 27,2 & 26,1 & 26,4 & 25,3 & 22,7 & 22,6 & 23,3 & 25,0 & 25,9 & 27,2 & 27,2 & 25,7 \\
\hline Temperatura mínima $\left({ }^{\circ} \mathrm{C}\right)$ & 21,9 & 20,9 & 20,1 & 18,6 & 16,2 & 14,9 & 15,5 & 17,9 & 19,9 & 20,9 & 21,4 & 19,7 \\
\hline Temperatura máxima $\left({ }^{\circ} \mathrm{C}\right)$ & 32,6 & 31,4 & 32,7 & 32,0 & 29,3 & 30,3 & 31,2 & 32,2 & 32,0 & 33,6 & 33,0 & 31,8 \\
\hline Pluviosidade (mm) & 274 & 212 & 189 & 123 & 56 & 22 & 16 & 21 & 48 & 100 & 177 & 219 \\
\hline \multicolumn{13}{|c|}{ REGIÃO DE JANGADA/MT } \\
\hline \multirow{2}{*}{ Parâmetros } & \multicolumn{12}{|c|}{ MESES } \\
\hline & Jan & Fev & Mar & Abr & Mai & Jun & Jul & Ago & Set & Out & Nov & Dez \\
\hline Temperatura média $\left({ }^{\circ} \mathrm{C}\right)$ & 26,4 & 26,2 & 25,7 & 24,8 & 23,1 & 21,7 & 21,7 & 22,9 & 24,1 & 24,3 & 25,0 & 25,5 \\
\hline Temperatura mínima $\left({ }^{\circ} \mathrm{C}\right)$ & 21,6 & 21,6 & 21,0 & 20,0 & 17,8 & 15,4 & 15,0 & 16,8 & 19,3 & 18,8 & 20,9 & 20,6 \\
\hline Temperatura máxima $\left({ }^{\circ} \mathrm{C}\right)$ & 31,3 & 30,9 & 30,5 & 29,7 & 28,5 & 28,0 & 28,5 & 29,0 & 29,0 & 29,8 & 29,1 & 30,4 \\
\hline Pluviosidade (mm) & 162 & 159 & 173 & 116 & 58 & 40 & 24 & 41 & 54 & 115 & 136 & 158 \\
\hline \multicolumn{13}{|c|}{ REGIAO DE ANGATUBA/SP } \\
\hline \multirow{2}{*}{ Parâmetros } & \multicolumn{12}{|c|}{ MESES } \\
\hline & Jan & Fev & Mar & Abr & Mai & Jun & Jul & Ago & Set & Out & Nov & Dez \\
\hline Temperatura média $\left({ }^{\circ} \mathrm{C}\right)$ & 23,1 & 23,0 & 22,1 & 20,0 & 17,5 & 16,5 & 16,2 & 17,4 & 18,9 & 20,2 & 21,6 & 22,3 \\
\hline Temperatura mínima $\left({ }^{\circ} \mathrm{C}\right)$ & 17,6 & 17,7 & 16,7 & 14,4 & 11,5 & 10,3 & 9,8 & 11,3 & 13,0 & 14,6 & 16,0 & 16,7 \\
\hline Temperatura máxima $\left({ }^{\circ} \mathrm{C}\right)$ & 28,6 & 28,3 & 27,6 & 25,7 & 23,5 & 22,7 & 22,6 & 23,6 & 24,9 & 25,9 & 27,2 & 27,9 \\
\hline Pluviosidade (mm) & 195 & 186 & 136 & 59 & 60 & 50 & 38 & 38 & 63 & 129 & 101 & 160 \\
\hline
\end{tabular}




\subsection{Amostragem e coleta dos materiais}

Foi selecionado um talhão plantado com teca, para cada tratamento nas idades de 9,5;14,4 e 18,7 anos para as plantações realizadas em Glória D’Oeste, Porto Espiridião e Rosário D’Oeste no Mato Grosso, respectivamente e com 9,4 anos no plantio de Angatuba/SP. Um inventário florestal expedito foi elaborado em cada talhão por tratamento, medindo-se os diâmetros a altura do peito (DAP) de cada árvore. A intensidade mínima de amostragem no talhão foi de $0,5 \%$ de indivíduos em relação à população original.

Foram escolhidas 10 árvores com DAP médio $( \pm 10 \%)$ para coleta das amostras. As árvores eram retas, não bifurcadas, sem doenças ou danos e de boa qualidade. Das 10 árvores, de cada tratamento, cinco delas foram usadas para a caracterização anatômica, determinação do teor de extrativos, ensaios físicos e mecânicos e ensaio de secagem drástica, das quais foram retiradas toras com 2,60 metros de comprimento a partir da base da árvore (figura 4). As outras cinco árvores de cada tratamento, com comprimento de 1,30 metros (figura 5), foram destinadas para determinação da porcentagem de casca, proporção entre cerne e alburno, rendimento do processo de desdobro e da produção de pisos.

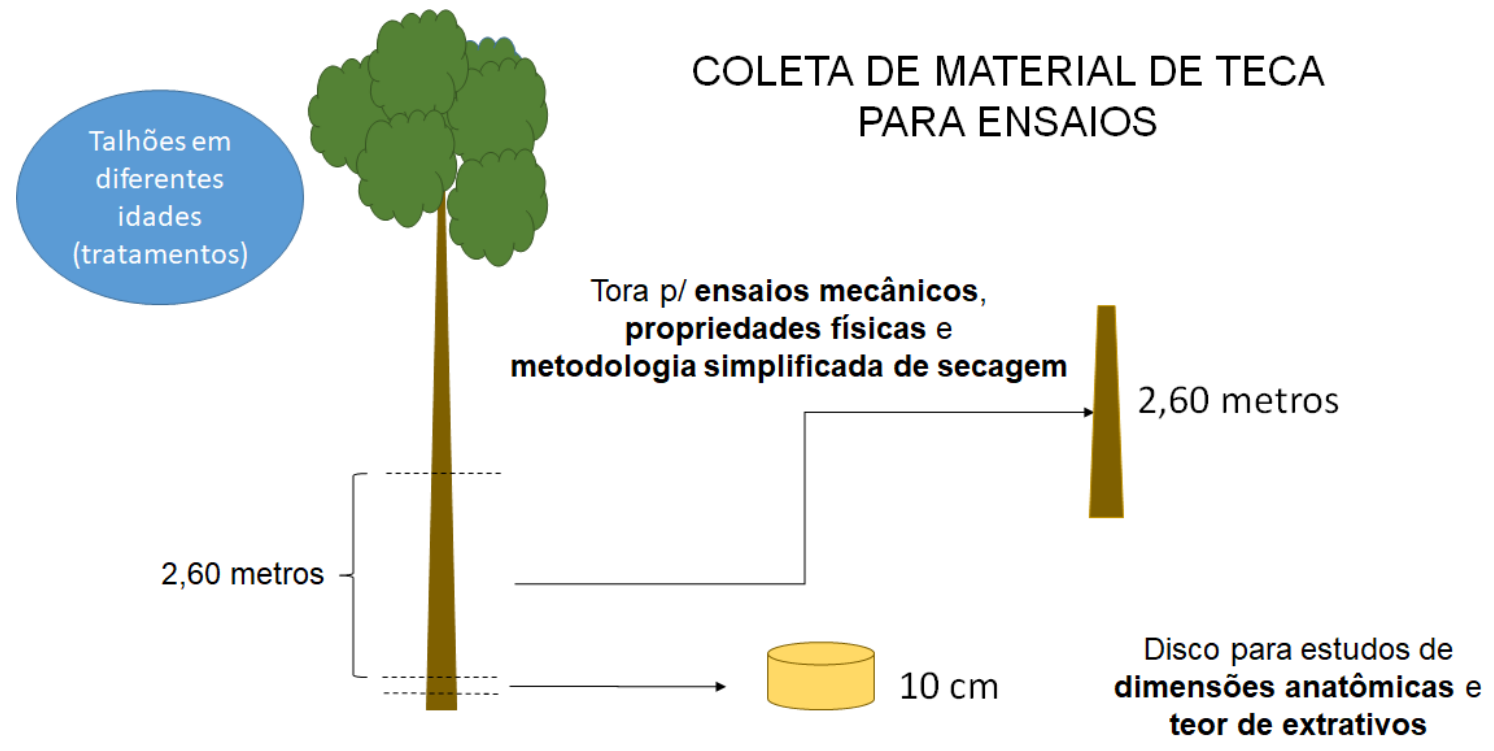

Figura 4. Esquema da coleta de amostras de madeira de teca para ensaios das propriedades físicas e mecânicas; dimensões anatômicas; determinação do teor de extrativos e ensaio de secagem drástica 


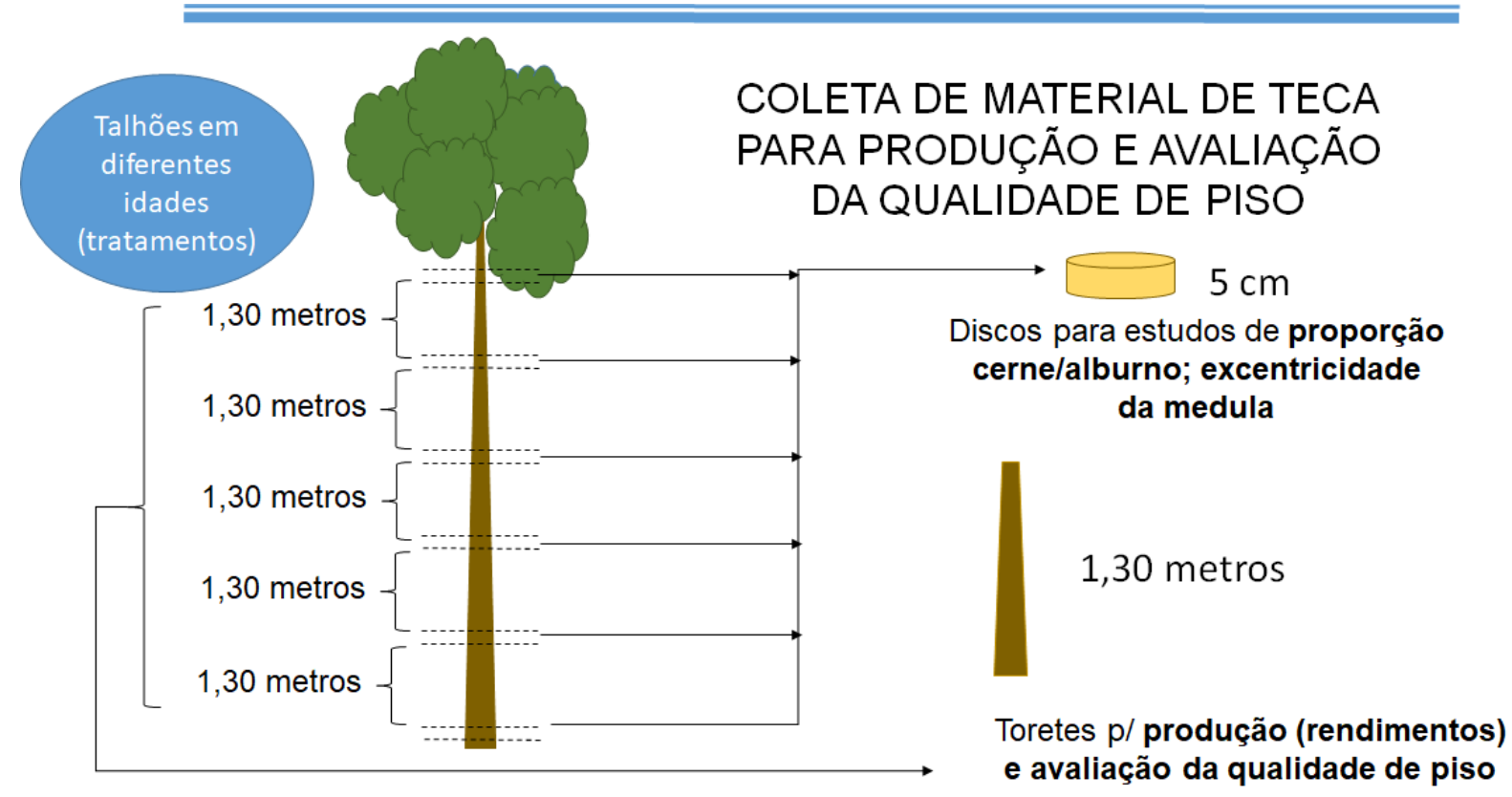

Figura 5. Esquema da coleta de amostras de madeira de teca para ensaios das proporções de cerne / alburno; excentricidade da medula e produção e avaliação da qualidade de pisos

Foram derrubadas 5 árvores por tratamento de árvores médias nos talhões escolhidos. Retirou-se um disco da base da árvore com $10 \mathrm{~cm}$ de espessura e uma tora de 2,60 metros, a partir do disco.

De cada tora, então com 2,60 metros, foi retirada uma prancha de $5 \mathrm{~cm}$ de espessura (figura 6 ). As pranchas foram enviadas para o secador de madeiras da Indusparquet até atingir a umidade aproximada de 12\%, usando-se um programa de secagem brando (tabela 7). Após a secagem, as pranchas foram enviadas ao LEMAD/ESALQ (Laboratório de Ensaios Mecânicos de Madeira e Derivados), para retirada dos corpos-de-prova, conforme dimensões apresentadas na tabela 4.

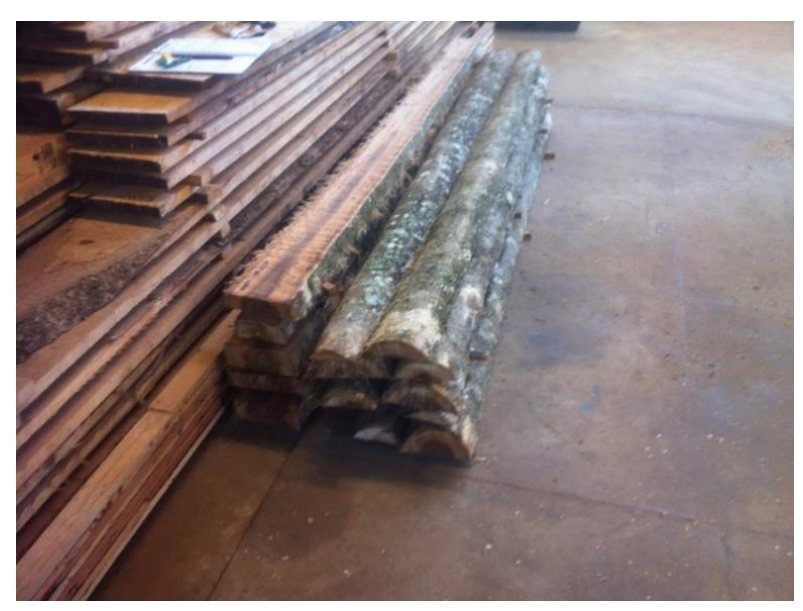

Figura 6. Pranchas retiradas de 5 árvores médias do tratamento de Angatuba/SP (plantio com 9,4 anos de idade) para ensaios mecânicos 
Tabela 4. Especificações dos ensaios mecânicos, de propriedades físicas da madeira e programa de secagem drástica, caracterização anatômica e determinação do teor de extrativos

\begin{tabular}{|c|c|c|c|c|c|}
\hline Ensaio & Norma & Planos da madeira & $\begin{array}{c}\text { Dimensão } \\
(\mathrm{mm})\end{array}$ & $\begin{array}{l}\text { Velocidade do ensaio } \\
\qquad\left(\mathrm{mm} \text { minuto }^{-1}\right)\end{array}$ & $\mathrm{N}^{\circ}$ repetições / tratamento \\
\hline Densidade básica & $\begin{array}{c}\text { ASTM (2011) } \\
\text { D2395-93 }\end{array}$ & $\begin{array}{l}\text { Cunhas dos discos da base } \\
\text { das toras de 2,60 metros }\end{array}$ & $\begin{array}{c}\text { Cunha } \\
\text { (1/4 do disco) }\end{array}$ & - & 5 árvores x 2 repetições (10) \\
\hline $\begin{array}{l}\text { Estabilidade } \\
\text { dimensional }\end{array}$ & $\begin{array}{l}\text { ASTM (2000) } \\
\text { D143-94 }\end{array}$ & $\begin{array}{c}\text { Direções radial, tangencial e } \\
\text { transversal }\end{array}$ & $25 \times 25 \times 100$ & - & 5 árvores x 12 repetições (60) \\
\hline $\begin{array}{l}\text { Metodologia } \\
\text { simplificada de } \\
\text { secagem }\end{array}$ & $\begin{array}{c}\text { JANKOWSKY } \\
\text { (1994) }\end{array}$ & Maior face tangencial & $\begin{array}{l}50 \times 10 \times 50 \\
50 \times 10 \times 100\end{array}$ & - & $\begin{array}{l}24 \text { amostras para secagem e } \\
24 \text { para densidade básica (48) }\end{array}$ \\
\hline $\begin{array}{l}\text { Compressão } \\
\text { paralela às fibras }\end{array}$ & $\begin{array}{l}\text { ASTM (2000) } \\
\text { D143-94 }\end{array}$ & Paralela às fibras & $25 \times 25 \times 100$ & 0,30 & 5 árvores x 12 repetições (60) \\
\hline Flexão estática & $\begin{array}{l}\text { ASTM (2000) } \\
\text { D143-94 }\end{array}$ & $\begin{array}{l}\text { Face tangencial sentido } \\
\text { radial convexo }\end{array}$ & $25 \times 25 \times 410$ & 1,30 & 5 árvores x 8 repetições (40) \\
\hline Cisalhamento & $\begin{array}{l}\text { ASTM (2000) } \\
\text { D143-94 }\end{array}$ & Faces tangencial e radial & $\begin{array}{c}20 \times 20 \\
(\text { dente de } 10 \\
\mathrm{mm})\end{array}$ & 0,60 & $\begin{array}{c}5 \text { árvores x } 10 \text { repetições x } 2 \\
\text { faces }(100)\end{array}$ \\
\hline Dureza Janka & $\begin{array}{c}\text { BS } 373 \\
\text { BSI (1957) }\end{array}$ & Faces tangencial e radial & $20 \times 20 \times 100$ & 0,60 & 5 árvores x 10 repetições (50) \\
\hline $\begin{array}{l}\text { Elementos } \\
\text { anatômicos }\end{array}$ & $\begin{array}{l}\text { SASS (1951) e } \\
\text { Franklin (1945) }\end{array}$ & $\begin{array}{c}\text { Transição entre cerne e } \\
\text { alburno }\end{array}$ & $25 \times 25 \times 25$ & - & - \\
\hline $\begin{array}{l}\text { Comprimento } \\
\text { fibra }\end{array}$ & & $\begin{array}{c}\text { Transição entre cerne e } \\
\text { alburno }\end{array}$ & Palitos & - & $\begin{array}{c}250 \text { repetições por tratamento } \\
\text { x componente } \\
\text { (alburno/cerne) }(2.000)\end{array}$ \\
\hline Diâmetro fibra & & $\begin{array}{c}\text { Transição entre cerne e } \\
\text { alburno }\end{array}$ & Palitos & - & $\begin{array}{c}50 \text { repetições por tratamento } \\
\text { x componente } \\
\text { (alburno/cerne) }(400)\end{array}$ \\
\hline $\begin{array}{l}\text { Espessura da } \\
\text { parede }\end{array}$ & & $\begin{array}{c}\text { Transição entre cerne e } \\
\text { alburno }\end{array}$ & Palitos & - & $\begin{array}{c}50 \text { repetições por tratamento } \\
\text { x componente } \\
\text { (alburno/cerne) }(400)\end{array}$ \\
\hline $\begin{array}{l}\text { Comprimento do } \\
\text { vaso }\end{array}$ & & $\begin{array}{c}\text { Transição entre cerne e } \\
\text { alburno }\end{array}$ & Lâmina & - & $\begin{array}{c}50 \text { repetições por tratamento } \\
\text { x componente } \\
\text { (alburno/cerne) }(400)\end{array}$ \\
\hline Diâmetro do vaso & & $\begin{array}{c}\text { Transição entre cerne e } \\
\text { alburno }\end{array}$ & Lâmina & - & $\begin{array}{c}50 \text { repetições por tratamento } \\
\text { x componente } \\
\text { (alburno/cerne) }(400)\end{array}$ \\
\hline
\end{tabular}

Foram derrubadas outras 5 árvores por tratamento com DAP médio nos talhões escolhidos. Foram traçados toretes de 1,35 metros a partir da base até o aproveitamento econômico das toras (figura 7), com diâmetro final de aproximadamente $10 \mathrm{~cm}$. Da base de todos os toretes retirou-se um disco de $5 \mathrm{~cm}$ para cálculo da proporção cerne/alburno/medula e da excentricidade da medula. 


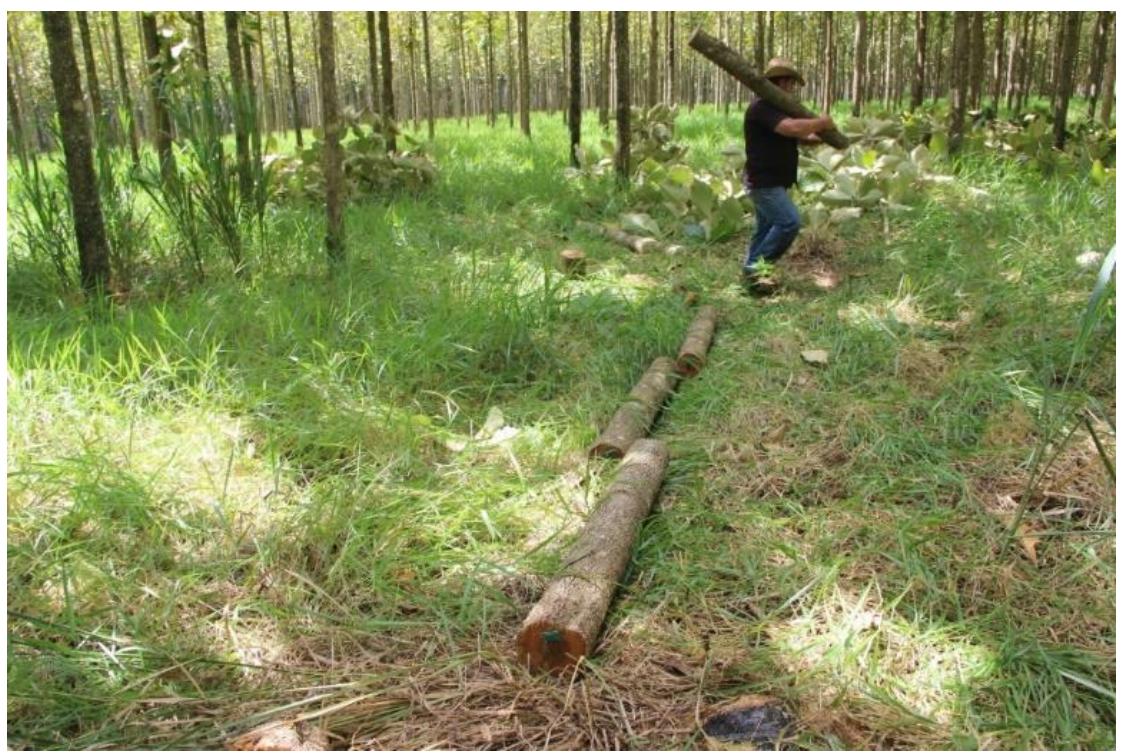

Figura 7. Toretes de 1,35 metros retirados de uma árvore média do tratamento de Angatuba/SP (plantio com 9,4 anos de idade) para produção de pisos e da determinação da relação cerne / alburno e excentricidade

\subsection{Volume comercial, área da casca, medula, cerne, alburno; proporção cerne/alburno, e excentricidade da medula}

Para o cálculo do volume comercial das árvores foram usados os toretes destinados à produção de pisos, antes da retirada dos discos usados para proporção de cerne e alburno. Cada um dos toretes foi cubado rigorosamente pela fórmula de Smalian, obtendo-se o volume com casca Vcc (1) e sem casca Vsc (2) de cada árvore. Assim, obtevese o teor de casca pela diferença dos dois volumes (3).

$V c c=\frac{\pi}{4} x \frac{D c c^{2}+d c c^{2}}{2} \times L$

Sendo que,

Vcc $=$ Volume com casca da seção do torete $\left(\mathrm{m}^{3}\right)$;

Dcc $=$ Diâmetro com casca da ponta mais grossa do torete $(\mathrm{m})$;

$\mathrm{dcc}=$ Diâmetro com casca da ponta mais fina do torete $(\mathrm{m})$;

$\mathrm{L}=$ Comprimento do torete $(\mathrm{m})$.

$V s c=\frac{\pi}{4} x \frac{D s c^{2}+d s c^{2}}{2} x L$

Sendo que:

Vsc $=$ Volume sem casca do torete $\left(\mathrm{m}^{3}\right) ;$

Dsc $=$ Diâmetro sem casca da ponta mais grossa do torete $(\mathrm{m})$;

$\mathrm{dsc}=$ Diâmetro sem casca da ponta mais fina do torete $(\mathrm{m})$;

$\mathrm{L}=$ Comprimento do torete $(\mathrm{m})$. 
Teor de $\operatorname{casca}(\%)=\frac{V c c-V s c}{V c c} \times 100$

Onde:

$\mathrm{Vcc}=$ Volume com casca $\left(\mathrm{m}^{3} \mathrm{ha}^{-1}\right)$;

Vsc $=$ Volume sem casca $\left(\mathrm{m}^{3} \mathrm{ha}^{-1}\right)$.

Os discos retirados da ponta mais grossa de cada um dos toretes usados para produção de pisos, ou seja, um disco a cada 1,30 metros de altura desde a base da árvore, foram polidos para o cálculo das áreas de medula, cerne e alburno. Para isso, foi usada uma câmara digital DSLR CANON EOS Rebel T3i com 18 MP, LCD de 3 polegadas, sensor CMOS, Full HD para fotografar cada um dos discos (figura 8). Para o cálculo da área de cada uma das partes do disco (medula, cerne, alburno e casca) foi usado o software de imagens Image $1.51 \mathrm{~J} 8$.

Para o cálculo da excentricidade da medula foi usada a fórmula (4), calculando-se o diâmetro médio do disco a partir da área informada pelo software de imagens.

$$
E X=\frac{L c}{d m} \times 100
$$

Onde:

EX = Excentricidade da medula (\%);

$\mathrm{Dm}=$ Diâmetro médio do disco $(\mathrm{cm})$;

Lc $=$ Distância entre o centro geométrico e a posição real da medula $(\mathrm{cm})$.

Para avaliação do comportamento dendrométrico das árvores foram medidos os anéis de crescimento em discos da base das árvores de cada tratamento, utilizando paquímetro digital com resolução de $0,01 \mathrm{~mm}$.

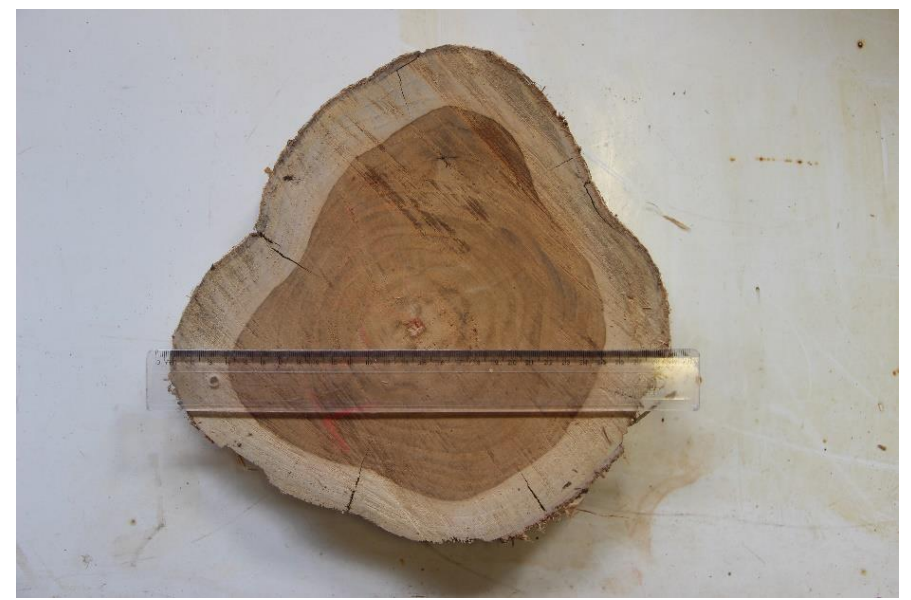

Figura 8. Disco fotografado para cálculo das áreas de medula, cerne e alburno e do valor de excentricidade da medula em relação ao diâmetro total do disco 


\subsection{Densidade básica da madeira}

A densidade básica da madeira foi determinada usando-se a norma D2395-93 (ASTM, 2000). Em cada tratamento foram retiradas duas cunhas da base de cada árvore, totalizando 10 amostras por tratamento. Essas amostras foram saturadas em água, obtendo-se a massa saturada e o volume pelo método da imersão em água. Obteve-se a massa seca, colocando-se as amostras em estufa a $103+2{ }^{\circ} \mathrm{C}$ até massa constante. A densidade básica foi obtida pela fórmula (5).

$$
\begin{aligned}
& D B=\frac{m s}{v s a t}, e m\left(\frac{g}{c^{3}}\right) \\
& \text { Onde: } \\
& \text { DB = Densidade básica }\left(\mathrm{g} \mathrm{cm}^{-3}\right) ; \\
& \text { ms = Massa seca (gramas); } \\
& \text { vsat = Volume saturado }\left(\mathrm{cm}^{3}\right) .
\end{aligned}
$$

\subsection{Estabilidade dimensional da madeira}

Para a determinação da retratibilidade da madeira foi utilizada a norma D143-94 (ASTM, 2000), a qual estabelece que as dimensões lineares sejam tomadas diretamente no corpo de prova, o que simplifica a metodologia. As dimensões das amostras foram de $2,5 \times 2,5 \times 10 \mathrm{~cm}$, sem defeitos e orientados nas faces radial, tangencial e longitudinal. Foram determinadas as contrações lineares, no sentido radial e tangencial, axial e a volumétrica em duas condições de umidade, ou seja, na condição saturada e absolutamente seca. Também foi obtido o coeficiente de anisotropia. As medições das dimensões lineares foram feitas com um paquímetro digital, com precisão de $0,01 \mathrm{~mm}$.

Os valores das contrações foram determinados pelas equações (6), (7) e (8).

Contração linear (6), em \%

$\beta=\frac{D v-D s}{D v} \times 100$

Contração volumétrica (7), em \%

$\beta v=\frac{V v-V s}{V v} \times 100$

Coeficiente de anisotropia (8).

$A=\beta t / \beta r$

Onde:

$\mathrm{Dv}=$ Dimensão linear na condição de volume saturado $(\mathrm{cm})$;

Ds=Dimensão linear na condição seca $(\mathrm{cm})$;

$\mathrm{V}_{\mathrm{v}}=$ Volume saturado $\left(\mathrm{cm}^{3}\right)$;

$\mathrm{Vs}=$ Volume da amostra em condição seca $\left(\mathrm{cm}^{3}\right)$;

$\beta=$ Contração linear tangencial $(\beta \mathrm{t})$ ou radial $(\beta \mathrm{r})(\%)$;

$A=$ Coeficiente de anisotropia. 


\subsection{Programa de secagem pelo método simplificado de secagem drástica}

Foram cortadas 10 amostras de cada árvore de todos os tratamentos para teste simplificado de secagem drástica. Dessas 50 amostras em cada tratamento, foram selecionadas 24 para cálculo de densidade básica e umidade inicial e outros 24 corpos de prova para o ensaio de secagem. As dimensões das amostras foram 10 x 50 x $100 \mathrm{~mm}$, sendo que o comprimento $(100 \mathrm{~mm})$ foi a dimensão paralela ao sentido das fibras.

A densidade básica foi determinada pelo método da balança hidrostática (BARRICHELLO, 1983) e tanto a massa seca das amostras como o teor de umidade inicial foram estimados por gravimetria, seguindo o método descrito por Galvão \& Jankowsky (1985).

As 24 amostras obtidas das 5 árvores foram selecionadas, eliminando-se as que apresentavam pequenos defeitos de corte (principalmente lascamentos e rachaduras) ou defeitos naturais. Após as medições de massa e identificações iniciais, as amostras foram colocadas em autoclave (figura 9) e imersas em água, com alternância de pressão e vácuo de 2 em 2 horas, totalizando 24 horas para saturação das amostras. Após esse período de saturação, medições das massas dos corpos de prova foram realizadas novamente.

Tabela 5. Variáveis avaliadas no ensaio de secagem drástica a $100^{\circ} \mathrm{C}$

\begin{tabular}{|c|c|c|c|}
\hline & Variável & $\begin{array}{c}\text { Faixa de umidade } \\
(\%)\end{array}$ & Unidade \\
\hline Ui & Umidade inicial & Verde & $\%$ \\
\hline DB & Densidade básica & Verde & $\mathrm{g} \mathrm{cm}^{-3}$ \\
\hline $\mathrm{m}_{1}$ & Massa inicial de água & Verde & $\mathrm{g}$ \\
\hline $\mathrm{m}_{30}$ & Massa de água a $30 \%$ & 30 & $\mathrm{~g}$ \\
\hline $\mathrm{m}_{5}$ & Massa de água a $5 \%$ & 5 & $\mathrm{~g}$ \\
\hline $\mathbf{T}_{1}$ & Tempo de secagem & Ui a 5 & $\mathrm{~h}$ \\
\hline $\mathbf{T}_{2}$ & Tempo de secagem & Ui a 30 & $\mathrm{~h}$ \\
\hline $\mathbf{T}_{3}$ & Tempo de secagem & 30 a 5 & $\mathrm{~h}$ \\
\hline $\mathrm{V}_{1}$ & Taxa de secagem & Ui a 5 & $\mathrm{~g} \mathrm{~cm}^{-2} \times \mathrm{h}$ \\
\hline $\mathbf{V}_{2}$ & Taxa de secagem & Ui a 30 & $\mathrm{~g} \mathrm{~cm}^{-2} \times \mathrm{h}$ \\
\hline $\mathbf{V}_{3}$ & Taxa de secagem & 30 a 5 & $\mathrm{~g} \mathrm{~cm}^{-2} \mathrm{xh}$ \\
\hline $\mathbf{R}_{1}$ & Rachadura de topo & Ui a 5 & $(*)$ \\
\hline $\mathbf{R}_{2}$ & Rachadura de topo & Ui a 30 & $(*)$ \\
\hline $\mathbf{R}_{3}$ & Rachadura de topo & 30 a 5 & $(*)$ \\
\hline $\mathbf{R}_{\mathbf{i}}$ & Rachadura interna & 5 & $(*)$ \\
\hline $\mathrm{CC}$ & Intensidade de colapso & 5 & $(*)$ \\
\hline
\end{tabular}

$(*)=$ escore, em função da intensidade do defeito, detalhado na tabela 6.

Fonte: Jankowsky (2009) 

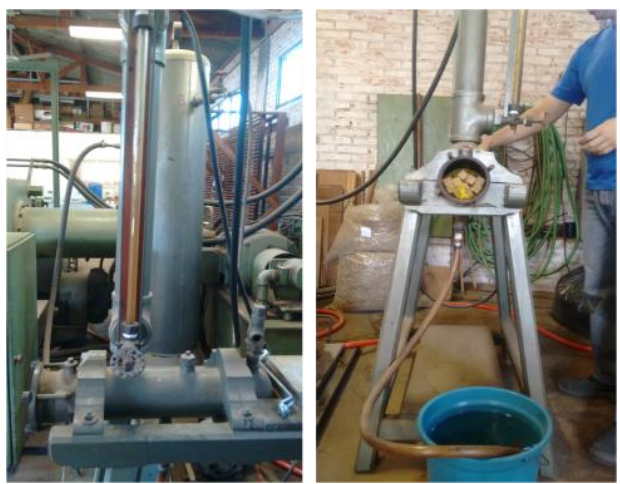

Figura 9. Autoclave usada para saturação das amostras de madeira

As amostras foram submetidas à secagem em estufa (Fanen, modelo 315SE, sem circulação forçada de ar), sob temperatura constante de $100^{\circ} \mathrm{C}$ (secagem drástica). Durante a secagem as amostras foram periodicamente pesadas e avaliadas quanto à incidência de defeitos (tabela 5), até que o teor de umidade fosse igual ou inferior a 5\%. O período de tempo entre as avaliações periódicas foi de 60 minutos.

As características da madeira e os defeitos de secagem avaliados durante a secagem drástica estão listados na tabela 5, sendo que o escore atribuído aos defeitos consta da tabela 6 .

Tabela 6. Quantificação do escore atribuído aos defeitos de secagem

\begin{tabular}{|c|c|c|c|c|}
\hline \multirow{2}{*}{ Escore } & \multicolumn{3}{|c|}{ Rachaduras } & \multirow{2}{*}{$\begin{array}{c}\text { Intensidade de } \\
\text { colapso }(*)\end{array}$} \\
\hline & De topo & Superficial & Interna & \\
\hline 1 & Ausente & Ausente & Ausente & Ausente \\
\hline \multirow{2}{*}{2} & $C R<\frac{e}{2}$ & $C R<\frac{c}{4}$ & $C R<\frac{e}{4}$ & \multirow{2}{*}{$A B<\frac{e}{40}$} \\
\hline & $L R<\frac{e}{20}$ & $L R<\frac{c}{400}$ & $L R<\frac{e}{20}$ & \\
\hline \multirow{2}{*}{3} & $C R>\frac{e}{2}$ & $C R<\frac{c}{2}$ & $C R<\frac{e}{4}$ & \multirow{2}{*}{$\frac{e}{20}>A-B>\frac{e}{40}$} \\
\hline & $L R<\frac{e}{20}$ & $L R<\frac{c}{200}$ & $L R>\frac{e}{20}$ & \\
\hline \multirow{2}{*}{4} & $C R<\frac{e}{2}$ & $C R<\frac{3 c}{4}$ & \multirow[t]{2}{*}{ - } & \multirow{2}{*}{$\frac{e}{10}>A-B>\frac{e}{20}$} \\
\hline & $\frac{e}{10}>L R>\frac{e}{20}$ & $L R<\frac{c}{100}$ & & \\
\hline \multirow{2}{*}{5} & $C R>\frac{e}{2}$ & $C R>\frac{3 c}{4}$ & \multirow{2}{*}{-} & \multirow{2}{*}{$A-B>\frac{e}{10}$} \\
\hline & $\frac{e}{10}>L R>\frac{e}{20}$ & $L R<\frac{c}{100}$ & & \\
\hline 6 & $\begin{aligned} C R & >\frac{e}{2} \\
L R & >\frac{e}{10}\end{aligned}$ & - & - & - \\
\hline \multicolumn{5}{|c|}{$\left(^{*}\right)=$ posicionamento das dimensões A e B ilustradas na figura 10} \\
\hline \multicolumn{5}{|c|}{$\mathrm{CR}=$ comprimento da rachadura $(\mathrm{mm})$} \\
\hline \multicolumn{5}{|c|}{$\mathrm{LR}=$ Largura da rachadura $(\mathrm{mm})$} \\
\hline $\mathrm{e}=$ espess & amostra (mm) & & & \\
\hline
\end{tabular}

Fonte: Jankowsky (2009) 
Após secagem, as amostras foram cortadas ao meio no sentido transversal às fibras, para medição das rachaduras internas e da intensidade do colapso, conforme esquema da figura 10. Depois, as amostras foram colocadas em estufa a $103^{\circ} \mathrm{C}( \pm 2)$ até massa constante. A massa constante é considerada como a massa seca das amostras (devidamente corrigida para compensar a perda de madeira devido ao corte transversal), e usada para calcular os teores de umidade inicial e ao longo da secagem drástica (equação 9) e também para o cálculo das taxas de secagem (equações 10,11 e 12).

$$
U=\left(\left(\frac{m u c}{m s}\right)-1\right) \times 100
$$

\section{Onde:}

$\mathrm{U}=$ teor de umidade $(\%)$;

muc $=$ massa úmida corrente da amostra (muc na preparação da amostra corresponde a massa inicial e o teor de umidade à umidade inicial) $(\mathrm{g})$;

$\mathrm{ms}=$ massa seca da amostra $(\mathrm{g})$.

$V 1=\frac{m u-m 5}{T 1 \times 2 A}$

Onde:

$\mathrm{V} 1=$ taxa de secagem da umidade inicial até $5 \%\left(\mathrm{~g} \mathrm{~cm}^{-2} \mathrm{~h}^{-1}\right)$;

$\mathrm{mu}=$ massa da amostra úmida (umidade inicial) $(\mathrm{g})$;

m5 = massa da amostra a 5\% de umidade (g);

$\mathrm{T} 1$ = tempo de secagem da umidade inicial até 5\% (h);

$\mathrm{A}=$ área superficial da amostra $\left(2 \mathrm{x}\right.$ largura $\mathrm{x}$ comprimento $\left.-\mathrm{cm}^{2}\right)$.

$v 2=\frac{m u-m 30}{T 2 \times 2 A}$

Onde:

V2 = taxa de secagem da umidade inicial até $30 \%\left(\mathrm{~g} \mathrm{~cm}^{-2} \mathrm{~h}^{-1}\right)$;

$\mathrm{mu}=$ massa da amostra úmida (umidade inicial) $(\mathrm{g})$;

m30 = massa da amostra a 30\% de umidade (g);

$\mathrm{T} 1$ = tempo de secagem da umidade inicial até $30 \%$ (h);

$\mathrm{A}=$ área superficial da amostra $\left(2 \mathrm{x}\right.$ largura $\mathrm{x}$ comprimento $\left.-\mathrm{cm}^{2}\right)$.

$V 3=\frac{m 30-m 5}{T 3 \times 2 A}$

Onde:

$\mathrm{V} 3=$ taxa de secagem de 30 a $5 \%$ de umidade $\left(\mathrm{g} \mathrm{cm}^{-2} \mathrm{~h}^{-1}\right)$;

$\mathrm{m} 30=$ massa da amostra a 30\% de umidade (g);

m5 = massa da amostra a 5\% de umidade (g);

$\mathrm{T} 3$ = tempo de secagem de 30 a 5\% de umidade (h);

$\mathrm{A}=$ área superficial da amostra $\left(2 \mathrm{x}\right.$ largura $\mathrm{x}$ comprimento $\left.-\mathrm{cm}^{2}\right)$. 
As rachaduras de topo foram medidas com auxílio de lâminas calibradoras de 0,05 a 1,00 mm (largura) e paquímetro digital com precisão de 0,01 $\mathrm{mm}$ (comprimento), considerando sempre a maior intensidade de ocorrência do defeito. A magnitude das rachaduras foi então transformada em escore, conforme classificação da tabela 6 .

Os períodos de tempo para que as amostras tenham atingido os teores de umidade de 30\% e de 5\% foram interpolados a partir de uma equação de regressão simples [do tipo y $=\mathrm{a}+\mathrm{b} \ln (\mathrm{x})$ ], estabelecida com base na curva de secagem individual das amostras. A massa úmida corrente, correspondente aos teores de umidade de 30\% e de 5\%, foi calculada com a equação 12 .

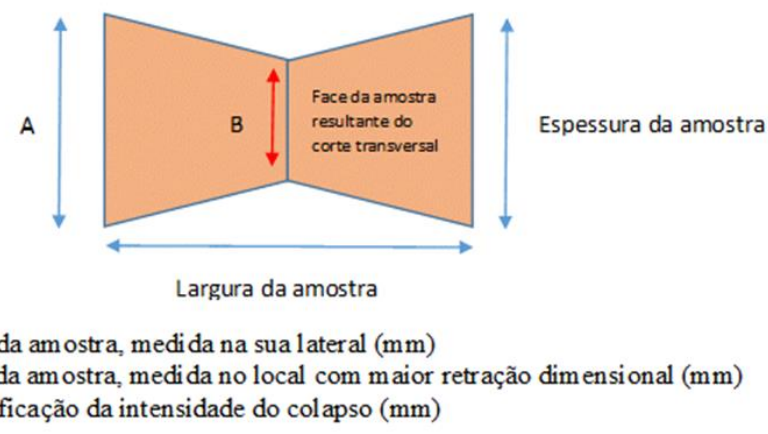

Figura 10. Esquema demonstrativo da quantificação de intensidade do colapso

\subsection{Caracterização anatômica}

\subsubsection{Preparo das lâminas histológicas}

Para a descrição da estrutura anatômica microscópica da madeira foram orientados corpos-de-prova $\left(2 \mathrm{~cm}^{3}\right)$ retirados da transição entre cerne e alburno e amolecidos por meio de cozimento em água e glicerina (4:1). As seções histológicas da madeira foram obtidas na espessura de 18-25 $\mu \mathrm{m}$, dos planos transversal e longitudinal (tangencial e radial), em micrótomo de deslize marca Leica. O processamento dos cortes anatômicos e a montagem de lâminas histológicas permanentes da madeira foram feitos de acordo com Sass (1951). Para a captura das imagens e a descrição das características microscópicas da madeira foi utilizado equipamento óptico dotado de lentes objetivas de diversos aumentos, utilizado para avaliação e caracterização da anatomia da madeira, acoplados com câmeras que permitem a captura de imagens de alta resolução. O equipamento contém câmeras digitais e computadores com softwares de análise de imagens "Image-Pro 6.3". Foram medidos os diâmetros dos vasos na região do alburno e do cerne, com 100 repetições por tratamento, sendo 50 medições no alburno e outras 50 medições no cerne.

\subsubsection{Mensuração dos elementos anatômicos dissociados (maceração)}

Os corpos-de-prova para maceração foram os mesmos obtidos na caracterização microscópica da madeira, ou seja, na transição entre o alburno e cerne para efetuar as medições dos elementos anatômicos nos dois componentes 
da amostra. Para a mensuração dos elementos anatômicos dissociados, foi preparado material macerado segundo o método de Franklin (1945).

Para a maceração, foram retirados pequenos fragmentos das madeiras com auxílio de um estilete e colocados em um tubo de ensaio juntamente com $10 \mathrm{~mL}$ de solução de ácido acético e peróxido de hidrogênio na proporção de 1:1; deixando-se macerar por um período de 24 horas em estufa à temperatura de $60^{\circ} \mathrm{C}$. Após este período o material foi retirado e lavado em água corrente, sendo armazenado em água destilada juntamente com safranina hidro-alcoólica no macerado. Com auxílio de um vídeo microscópio computadorizado (analisador de imagens) foram mensurados os comprimentos das fibras no alburno e no cerne, com 250 repetições por tratamento no alburno e 250 medições feitas no cerne, totalizando 500 repetições desse parâmetro em cada tratamento. Para a espessura das fibras e comprimento e largura dos vasos foram medidas 10 amostras por componente de cada árvore, ou seja, 50 repetições por tratamento no alburno e a mesma quantidade no cerne.

\subsection{Ensaios de propriedades mecânicas}

Foram realizados ensaios mecânicos para a determinação das seguintes propriedades: 1) Compressão paralela às fibras: Resistência máxima; 2) Flexão estática: Módulo de Elasticidade (MOE) e Módulo de Ruptura (MOR);

3) Cisalhamento: Resistência máxima; e; 3) Dureza Janka. Os corpos de prova foram acondicionados à temperatura de $20 \pm 3^{\circ} \mathrm{C}$ e umidade relativa de $65 \pm 5 \%$ para atingir umidade de equilíbrio, em torno de $12 \%$.

$\mathrm{Na}$ tabela 4 foram descritas as condições em que foram realizados os ensaios mecânicos, a dimensão dos corpos de prova, o número de corpos de prova utilizados e a norma considerada. Os ensaios foram realizados na Máquina Universal Mecânica UMC-300, com capacidade de 30 toneladas e com célula de carga de $10.000 \mathrm{~kg}$ para o ensaio de compressão e de $2.000 \mathrm{~kg}$ para os ensaios de flexão, cisalhamento e dureza. Os ensaios foram realizados no LEMAD / ESALQ (Laboratório de Ensaios Mecânicos e Derivados) e as especificações dos testes foram as seguintes: na compressão paralela velocidade de ensaio $0,3 \mathrm{~mm}$ por minuto e direção da força no sentido paralelo às fibras. $\mathrm{Na}$ flexão estática a velocidade de ensaio foi de $1,3 \mathrm{~mm}$ por minuto e distância entre apoios de $360 \mathrm{~mm}$. No cisalhamento os corpos de prova foram divididos em amostras com área de cisalhamento tangencial e radial. Na dureza Janka a velocidade de ensaio foi de 0,6mm por minuto $^{-1}$ e a norma usada foi a BS-373 (BSI, 1957).

\subsection{Ensaios para obtenção dos teores de extrativos na madeira}

A preparação do material para análise dos extrativos consistiu na obtenção de "palitos" da madeira a partir das cunhas opostas obtidas da base das toras. O material foi climatizado até estabilização da umidade, moído em moinho tipo Macro Willey e a serragem obtida foi peneirada em malha de 40 para 60 mesh, mantendo o conjunto de peneiras em agitação por 5 minutos, no agitador eletromagnético. Após a classificação da serragem, o material foi deixado em condições de ambiente para equilibrar a umidade. As amostras foram preparadas em um frasco de boca larga com tampa, permitindo a vedação perfeita. A norma utilizada foi a NBR 14.660 (ABNT, 2004).

Para calcular o teor de extrativos totais foi usada equação (13).

E.T. $(\%)=\{M s i-(M s f-\operatorname{tara})\} * 100$ 
onde:

E.T. $(\%)=$ teor de extrativos totais

Msi = aproximadamente 1 grama de serragem seca;

Msf = massa do cadinho com a serragem, após extração com solução álcool / tolueno 1:2 e extração em álcool etílico P.A. 95\%.

\subsection{Produção de pisos da madeira de teca}

As cinco árvores de cada tratamento, destinadas à produção de piso de madeira maciço, foram cortadas em toras de 1,30 metros de comprimento, até a ponta de diâmetro mínimo aproveitável de $10 \mathrm{~cm}$, para a produção de piso.

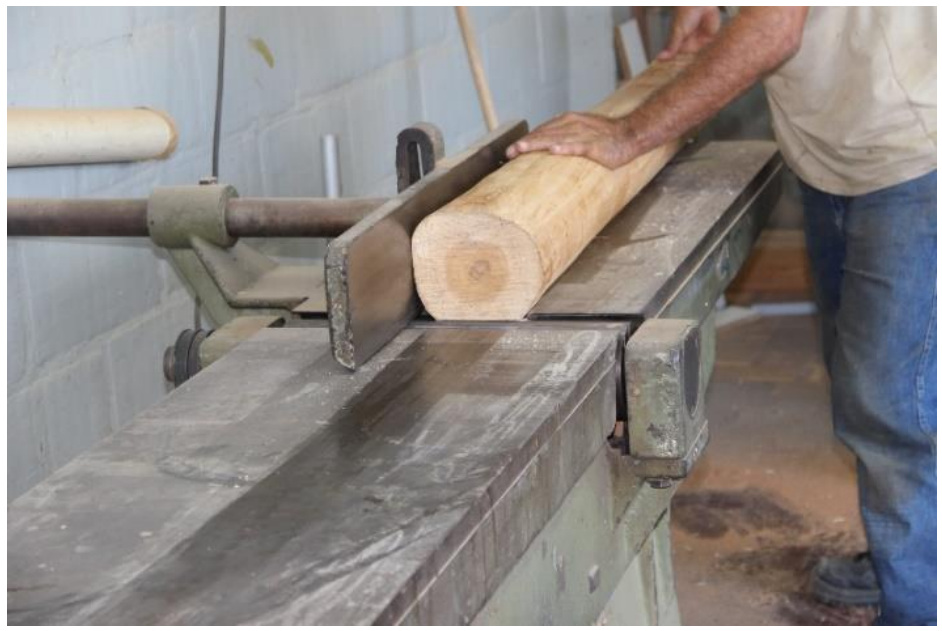

Figura 11. Plaina desempenadeira usada para alisamento de um dos lados das toras de teca

Essa madeira foi descascada e aplainada em uma plaina desempenadeira Invicta de 3 facas (figura 11). Após o alisamento de um dos lados da tora, usou-se uma serra fita Mill para o corte das tábuas com $27 \mathrm{~mm}$ de espessura (figura 12). Após o corte, as tábuas foram destopadas em uma destopadeira de mesa. As larguras definidas para a produção do piso foram de 75 e $89 \mathrm{~mm}$. 


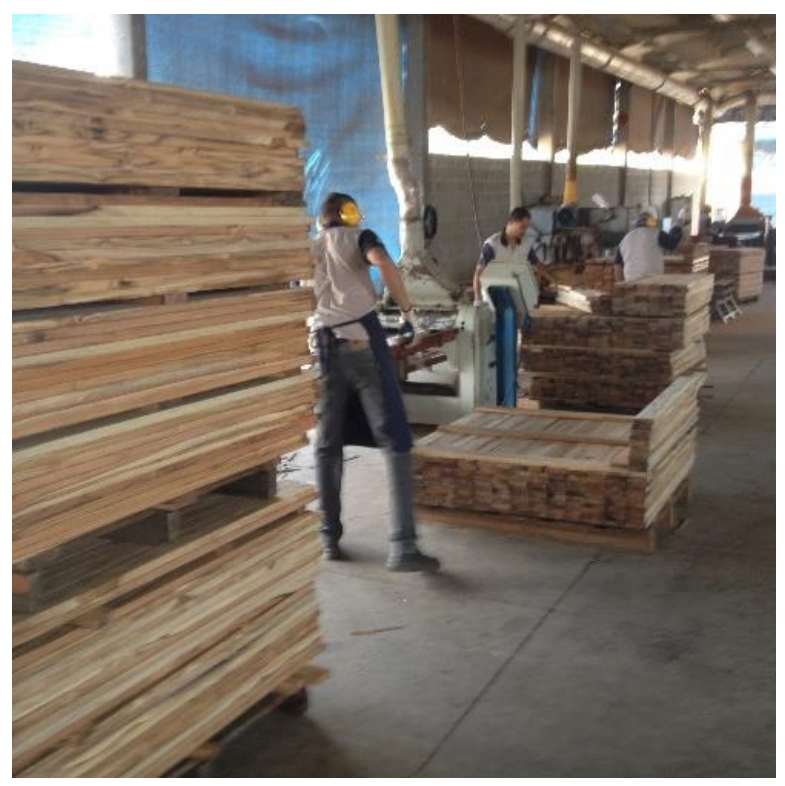

Figura 12. Serra fita usada para corte das tábuas de teca
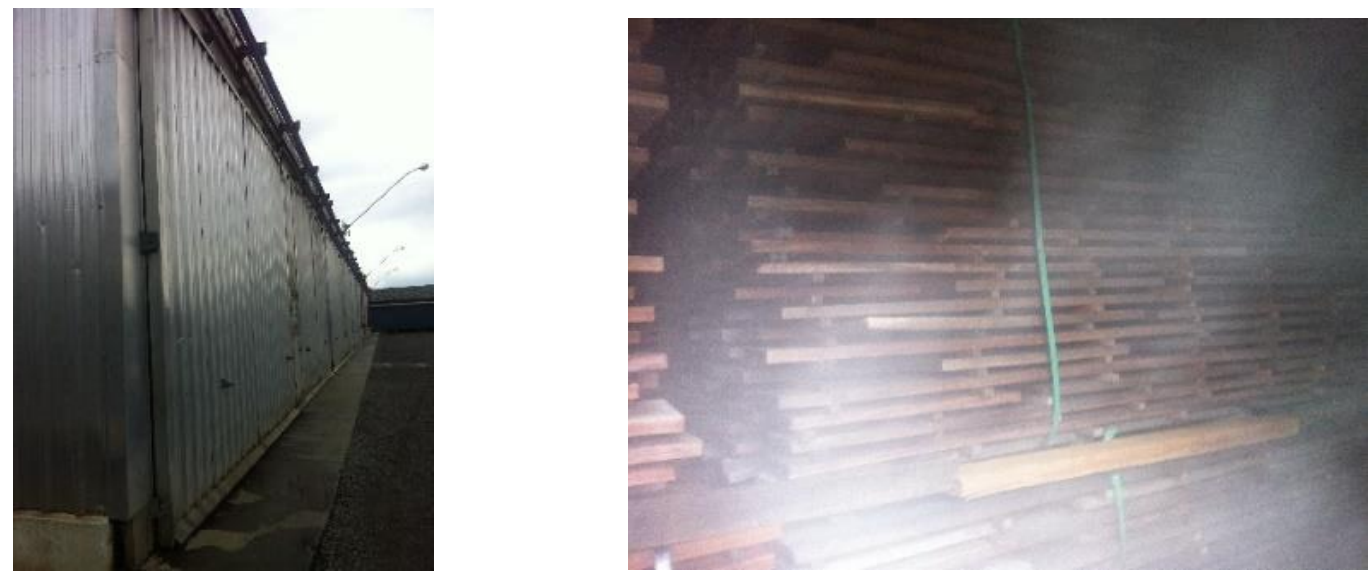

Figura 13. Secagem da madeira de teca em secador comercial da Indusparquet

As tábuas foram colocadas em estufa a vapor, sistema de banho a água e vapor, com abertura de "dampers" e inversão dos ventiladores automática. A programação de secagem (tabela 7), inicia-se com temperatura de $48,4^{\circ} \mathrm{C}$ e termina com a porcentagem de umidade de $8 \%$, atingindo a temperatura de $72,3^{\circ} \mathrm{C}$ no final do processo, sendo considerado uma secagem branda. As estufas são da marca Gottert, com controlador Marrari de Automação Industrial (figura 13).

O índice de conversão e rendimento das tábuas e pisos foram calculados pela medição do volume das toras, tábuas e pisos após o beneficiamento.

Depois da secagem das tábuas, o piso foi produzido em moldureira Unimart 23 EL com espessura de $19 \mathrm{~mm}$ (figura 14), destopado e lixado em Lixadeira Maclinea banda larga, antes do acabamento. Foram feitos os macho-fêmea na ponta dos pisos, com equipamento GMC e o produto foi envernizado num sistema ERS 130 T da Maclinea.

Tabela 7. Programa de secagem usado para secar as amostras de madeira a $8 \%$ de umidade 


\begin{tabular}{cccccc}
\hline UMIDADE & Ts $\left({ }^{\circ} \mathbf{C}\right)$ & Tu $\left({ }^{\circ} \mathbf{C}\right)$ & UR (\%) & UE (\%) & PS \\
\hline Aquecimento & 48,4 & 47,4 & 95 & 21,6 & $* *$ \\
\hline Acima de 50 & 48,4 & 44,8 & 81 & 15 & $>3,3$ \\
50 & 48,4 & 44,8 & 81 & 15 & 3,3 \\
45 & 48,4 & 44,4 & 79 & 14 & 3,2 \\
40 & 48,4 & 44 & 76 & 13 & 3,1 \\
35 & 48,4 & 42,9 & 71 & 11,9 & 2,9 \\
\hline 30 & 48,4 & 40,5 & 61 & 10,9 & 2,7 \\
\hline 25 & 54,4 & 45,2 & 58 & 9,1 & 2,7 \\
20 & 60,3 & 48,3 & 50 & 7,3 & 2,7 \\
15 & 66,3 & 48,3 & 37 & 5,5 & 2,7 \\
10 & 72,3 & 46,3 & 25 & 3,7 & 3 \\
5 & 72,3 & 42,3 & 17 & 1,9 & 3 \\
\hline Uniformização & 72,3 & 56,5 & 45,5 & 6 & $* *$ \\
Condicionamento & 72,3 & 67,5 & 79 & 12 & $* *$ \\
\hline
\end{tabular}

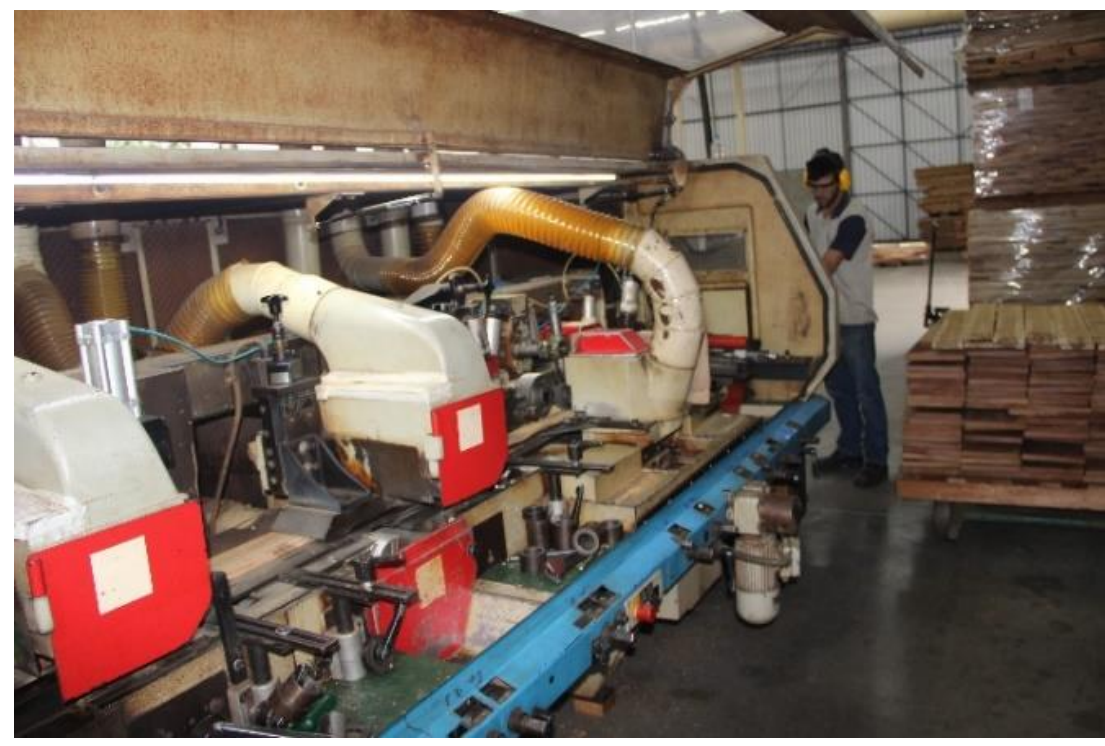

Figura 14. Produção de piso maciço de teca em moldureira da Indusparquet

O esquema de produção dos pisos de teca é apresentado na figura 15. 


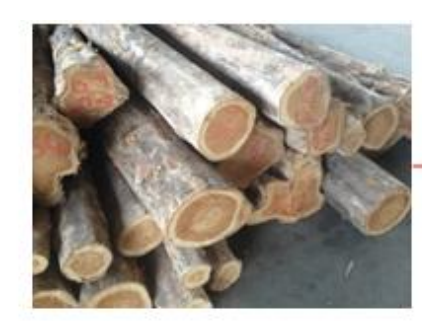

Tora com casca

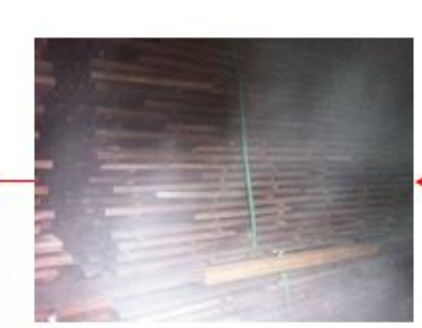

Secagem em estufa

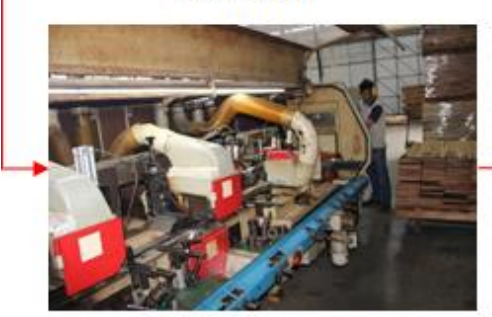

Moldureira beneficiamento piso

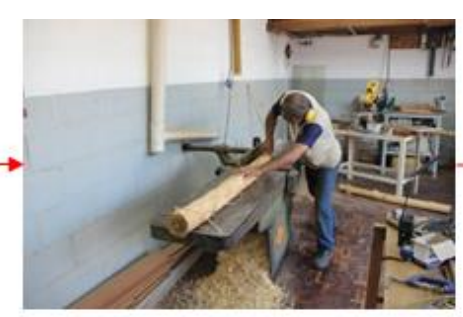

Tora descascada sendo aplainada

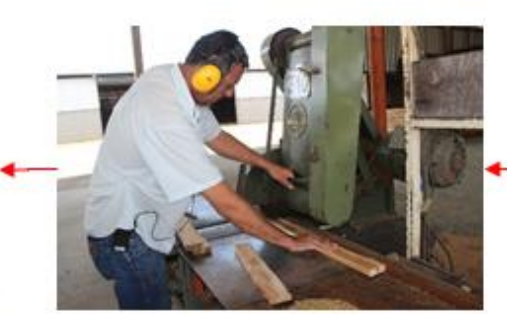

Destopadeira

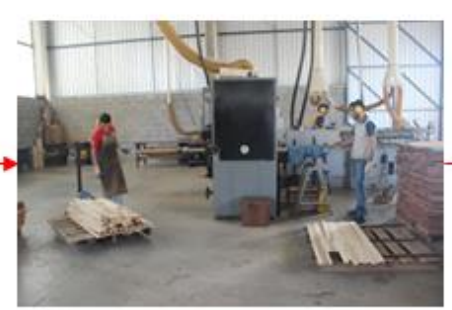

Lixamento do piso antes acabamento

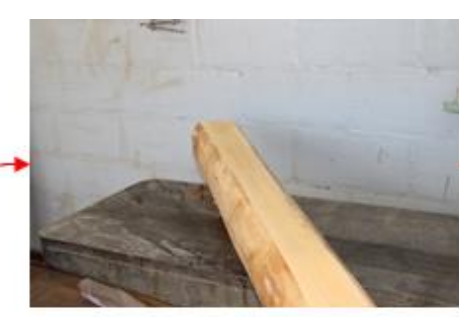

Um lado da tora aplainada

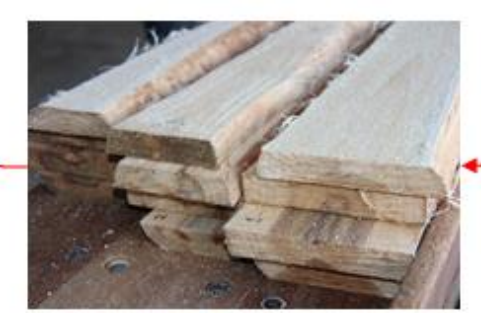

Tábuas de 75 e 89 mm largura

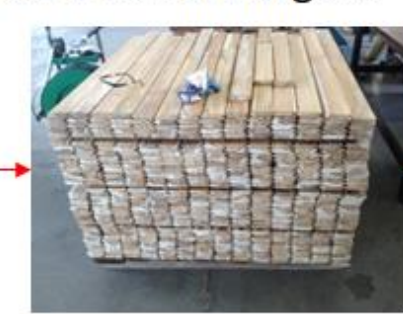

Piso pronto sem acabamento

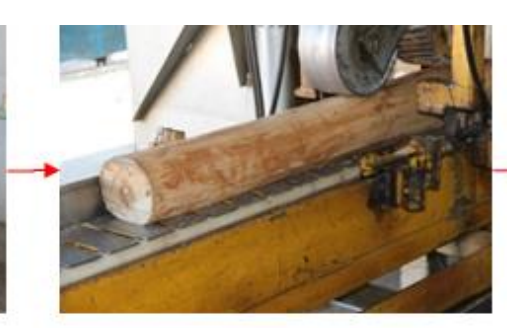

Serra fita corte de tábuas

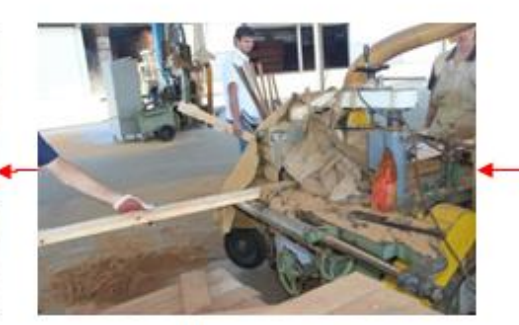

Alinhadeira

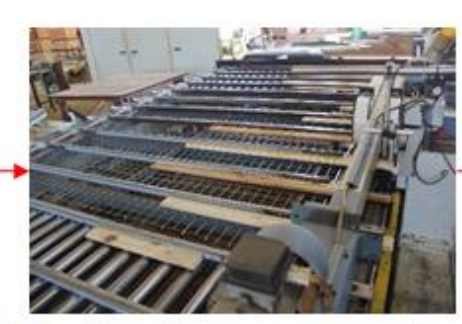

Macho-fêmea na ponta e bisotê

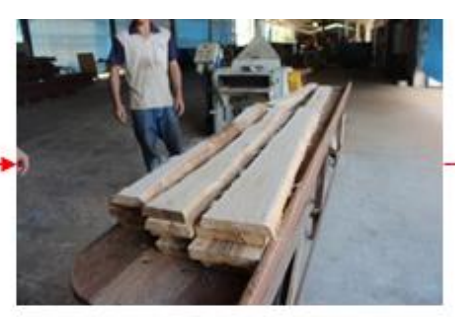

Tábuas de $27 \mathrm{~mm}$ espessura

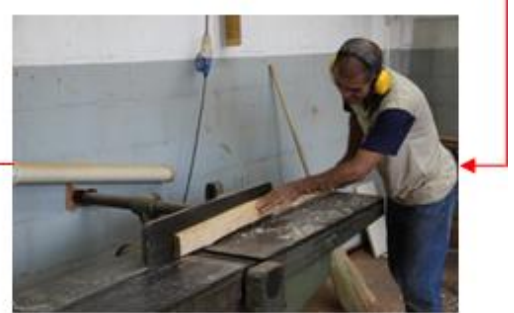

Plaina de um lado da tábua

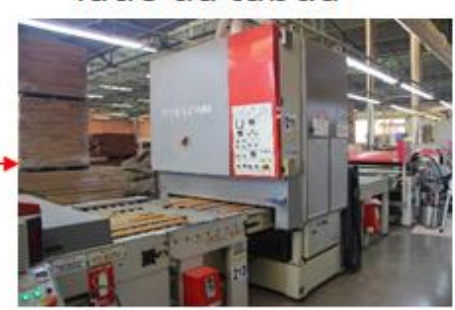

Envernizamento

Figura 15. Esquema de produção de piso de teca 


\subsection{Ensaios da qualidade de piso da madeira de teca}

As normas usadas para os ensaios de qualidade dos pisos de teca, as dimensões dos corpos de prova e o número de repetições de amostras são apresentados na tabela 8.

Tabela 8. Caracterização dos ensaios da qualidade dos pisos de teca

\begin{tabular}{|c|c|c|c|}
\hline Ensaio & Norma & $\begin{array}{c}\text { Dimensão corpo de prova } \\
(\mathrm{mm})\end{array}$ & $\begin{array}{c}\text { No de repetições por } \\
\text { tratamento }\end{array}$ \\
\hline $\begin{array}{c}\text { Resistência ao impacto } \\
\text { (dureza) }\end{array}$ & $\begin{array}{c}\text { ABNT (2004) } \\
\text { NBR } 14535 \text { ISO } 2813\end{array}$ & $76 \times 19 \times 300$ & 5 árvores x 7 repetições (35) \\
\hline Rugosidade & $\begin{array}{l}\text { ABNT (2004) } \\
\text { NBR } 8404\end{array}$ & $76 \times 19 \times 300$ & 5 árvores x 7 repetições (35) \\
\hline Brilho & $\begin{array}{c}\text { ABNT (2004) } \\
\text { NBR } 14535 \text { ISO } 2813\end{array}$ & $76 \times 19 \times 300$ & 5 árvores x 7 repetições (35) \\
\hline
\end{tabular}

\subsection{Análise Estatística}

$\mathrm{Na}$ avaliação do experimento foi utilizada análise de variância e teste Tukey a nível de 5\% para comparação entre os tratamentos, com as correspondentes medidas de variação dos dados, considerando cada árvore como repetição. Os resultados das propriedades mecânicas das toras e dos pisos produzidos foram apresentados na forma de equações de regressão para mostrar as tendências das qualidades avaliadas em função da idade dos plantios e da sua correlação, utilizando-se o coeficiente de correlação de Pearson. O programa de análise usado foi o SAS - University Edition. 


\section{RESULTADOS E DISCUSSÕES}

\subsection{Variáveis dendrométricas das toras de teca}

Os volumes comerciais das toras coletadas nos tratamentos estudados e as informações sobre densidade populacional e os desbastes ocorridos nas áreas florestais de teca em cada tratamento são apresentados na tabela 9. Nota-se que, existem diferenças no manejo de desbaste adotado, na população remanescente para cada tratamento entre as idades e as regiões estudadas, as quais determinam resultados dendrométricos com diferenças influenciadas por diversos fatores.

Tabela 9. Variáveis dendrométricas calculadas nas toras de teca amostradas no Mato Grosso em diferentes idades (9,5; 14,4 e 18,7 aos) e em Angatuba/SP na idade de 9,4 anos e informações sobre o manejo de desbaste usado em cada tratamento

\begin{tabular}{|c|c|c|c|c|c|c|c|c|c|c|}
\hline Fazenda & Município & $\begin{array}{l}\text { Idade } \\
\text { (anos) }\end{array}$ & $\begin{array}{c}\text { Espaç. } \\
\text { inicial } \\
\text { (m) }\end{array}$ & $\begin{array}{c}\text { Pop. } \\
\text { inicial } \\
(\text { árv ha-1) }\end{array}$ & $\begin{array}{c}\text { No } \\
\text { desbastes }\end{array}$ & $\begin{array}{c}\text { Pop. } \\
\text { remanesc. } \\
\text { (árv ha-1) }^{-1}\end{array}$ & $\begin{array}{l}\text { \% de árvores } \\
\text { desbastadas }\end{array}$ & $\begin{array}{l}\text { DAP } \\
\text { médio } \\
(\mathrm{cm})\end{array}$ & $\begin{array}{l}\text { Altura } \\
\text { com. } \\
\text { (m) }\end{array}$ & $\begin{array}{c}\text { Vol. médio } \\
\text { por árvore } \\
\left(\mathrm{m}^{3}\right)\end{array}$ \\
\hline Santa Maria & Angatuba/SP & 9,4 & $3 \times 2$ & 1.667 & 2 & 950 & 43,01 & 14,8 & 6,75 & $0,1005 \mathbf{d}$ \\
\hline Mutum & $\begin{array}{c}\text { Glória } \\
\text { D’Oeste/MT }\end{array}$ & 9,5 & $4 \times 3$ & 833 & 2 & 458 & 45,02 & 21,4 & 13,50 & $0,3038 \mathbf{c}$ \\
\hline $\begin{array}{c}\text { Santa Maria } \\
\text { do Jauru }\end{array}$ & $\begin{array}{c}\text { Porto } \\
\text { Espiridião/MT }\end{array}$ & 14,4 & $3 \times 3$ & 1.111 & 3 & 195 & 82,45 & 28,3 & 15,66 & $0,5768 \mathbf{b}$ \\
\hline Panflora & $\begin{array}{c}\text { Rosário } \\
\text { D’Oeste/MT }\end{array}$ & 18,7 & $3 \times 3$ & 1.111 & 5 & 135 & 87,85 & 33,3 & 15,12 & $0,8241 \mathbf{a}$ \\
\hline
\end{tabular}

*Médias de volume médio por árvore, seguidas de mesma letra não diferem estatisticamente entre si, pelo teste de Tukey, a nível de $5 \%$ de probabilidade

As florestas da Fazenda Santa Maria e Mutum apresentam praticamente a mesma idade e as porcentagens de desbaste de ambas são bastante similares até o momento, ou seja, 43,01 e 45,02\% de árvores removidas do plantio respectivamente (tabela 9). Entretanto, nota-se que a população remanescente do povoamento do estado de São Paulo é praticamente o dobro da floresta estudada na Fazenda Mutum. A densidade encontrada é de 950 árvores por hectare no povoamento de Angatuba/SP, contra 458 árvores por hectare na Fazenda de Glória D’Oeste/MT. Essa variação na quantidade de árvores remanescentes, em função da população inicial, influenciou o volume individual comercial desses tratamentos, que apresentou valor médio de $0,3038 \mathrm{~m}^{3}$ na Fazenda Mutum, no estado do Mato Grosso, mas foi somente de 0,1005 $\mathrm{m}^{3}$ por árvore, na Fazenda Santa Maria, em Angatuba/SP (tabela 9 e figura 16). Os resultados de Vincent et al. (2000), que avaliaram o desenvolvimento da teca em diferentes espaçamentos, variando desde $2 \times 2$ até 4 × 4 metros e regimes de desbaste mais e menos intensos em plantios realizados na Venezuela, mostraram que, os espaçamentos mais largos adotados e/ou os regimes mais intensos de desbaste resultaram em diâmetros maiores das árvores, em avaliação realizada aos 19 anos de idade. Esse mesmo estudo sugere que não há risco de danos ao plantio com a implementação de fortes desbastes tardios de até $60 \%$ da densidade original e que o melhor regime para a produção de serraria parece ser o de amplo espaçamento inicial (4 x 4 m), e com um desbaste comercial entre 10 e 14 anos de idade. Vale salientar que, na floresta da Fazenda Santa Maria, com população remanescente de 950 árvores por hectare, o DAP médio foi de 14,8 cm, enquanto no povoamento com 458 árvores por hectare, o DAP médio foi 44,6\% maior, ou seja, 21,4 cm (tabela 9). 
Da mesma forma, o volume dos povoamentos amostrados nesse estudo, no estado do Mato Grosso, apresentou uma função linear positiva em função das idades (figura 16), com significância para $\mathrm{r}^{2}$ a nível de 1\%. Assim, o volume médio por árvore da floresta com 18,7 anos de idade foi 42,9\% maior do que a floresta com 14,4 anos, que por sua vez, apresentou volume 89,9\% maior do que a média das árvores do povoamento de 9,5 anos de idade. Porém, é importante enfatizar, considerando apenas os plantios do Mato Grosso, que os povoamentos mais velhos apresentaram densidade populacional de 195 e 135 árvores por hectare, respectivamente para os plantios de 14,4 e 18,7 anos, enquanto o plantio de 9,5 anos de idade estava com 458 árvores por hectare. Devido, as variações climáticas e de manejo entre os povoamentos do Mato Grosso e aquele plantado em São Paulo (tabela 9), o volume individual médio desse último plantio apresentou apenas $0,1005 \mathrm{~m}^{3}$ por árvore.

Em povoamentos de teca com 9 anos de idade em Rondônia, com espaçamento inicial de 4 × 3 metros, Vieira et. al. (2008) observaram volume médio da ordem de $0,23 \mathrm{~m}^{3}$ por árvore, que ficou entre os volumes apresentados no tratamento com teca plantada no estado de São Paulo (0,1005 m³ por árvore) e o da Fazenda Mutum, plantado no Mato Grosso (0,3038 $\mathrm{m}^{3}$ por árvore), ambos com aproximadamente 9,5 anos de idade. Vale salientar que, nesse estudo não houve nenhum desbaste antes da avaliação de produtividade.

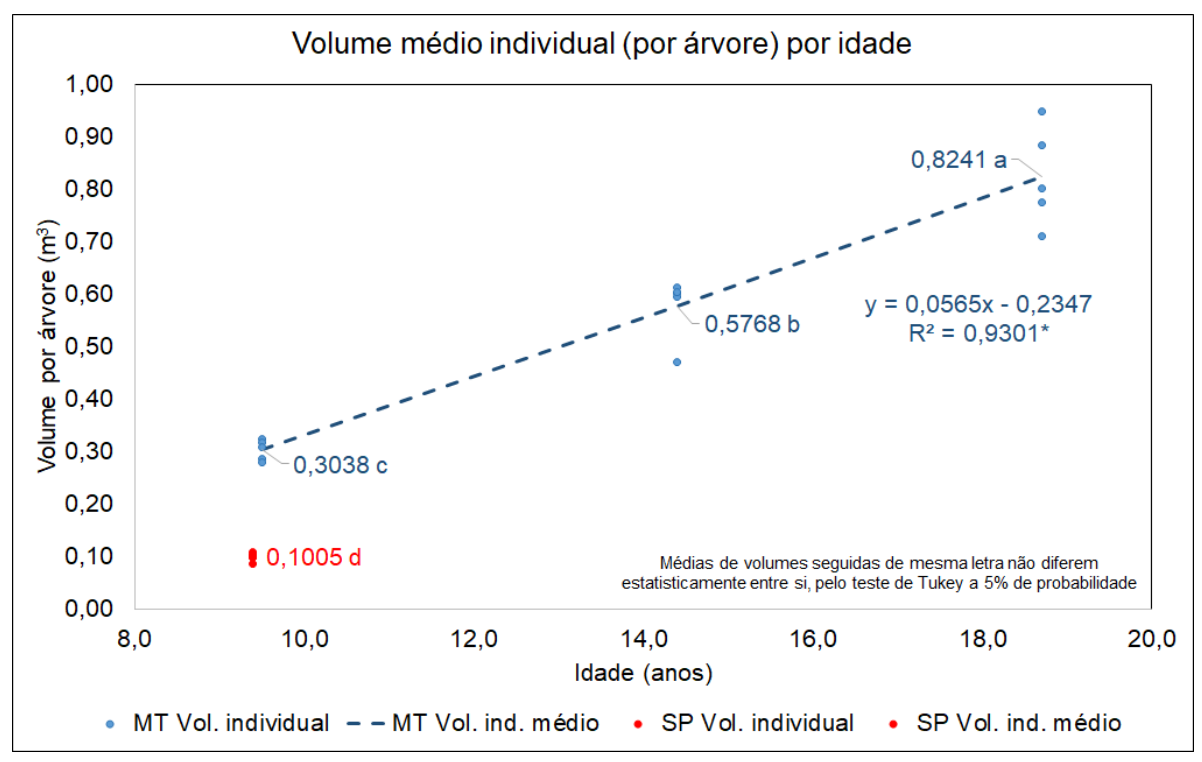

Figura 16. Volume comercial individual das árvores de teca em diferentes idades e regiões

Na figura 17 pode-se observar as espessuras dos anéis de crescimento da teca em todos os tratamentos. Pelos gráficos A e B, é possível observar que o arranque inicial do plantio de teca com idade próxima dos 20 anos foi maior do que nos outros plantios, com idades inferiores. Entretanto, esse plantio foi realizado em dezembro, enquanto a fazenda com 14,4 anos de idade foi plantada em março e as outras duas com idades próximas de 9,5 anos foram plantadas em fevereiro e novembro, respectivamente para a Fazenda Mutum (MT) e Fazenda Santa Maria (SP). Portanto, o menor desenvolvimento inicial da Fazenda Sta. Maria do Jauru (14,4 anos de idade), em relação as outras plantações, teve influência da época em que ela foi implantada, ou seja, início da época seca no estado do Mato Grosso.

No gráfico B da figura 17, onde as datas de plantio foram recuadas até o mesmo ponto de partida para todas as fazendas $\left(1^{\circ}\right.$ ano), nota-se que a Fazenda Sta. Maria de Angatuba/SP teve um bom crescimento inicial, mas 
perdendo esse efeito já no segundo ano de crescimento, por causa da alta densidade populacional, ou seja, 1.667 árvores por hectare, contra 833 na Fazenda Mutum e 1.111 árvores por hectare nos plantios das Fazendas Sta. Maria do Jauru e Panflora.

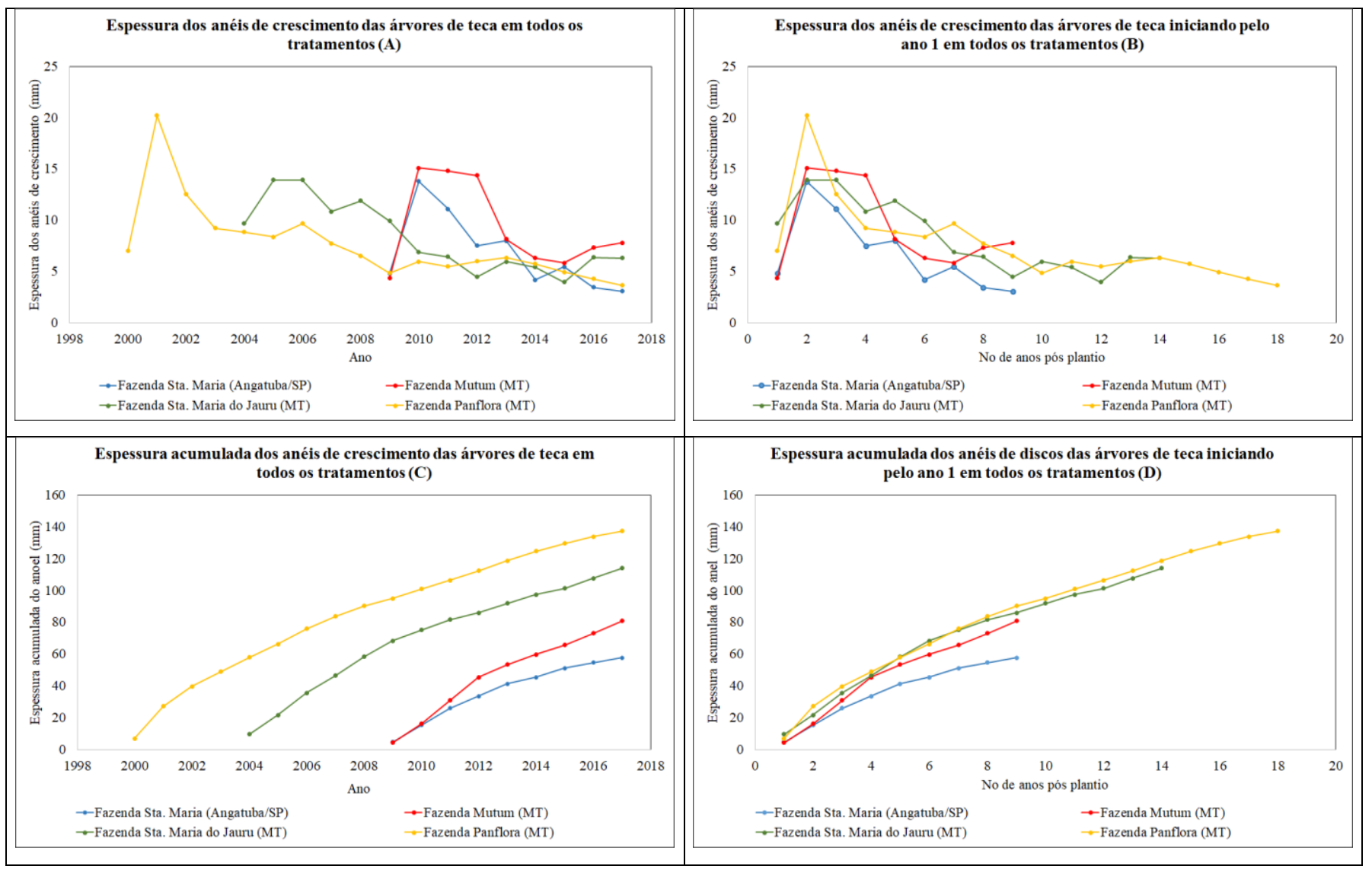

Figura 17. Espessura dos anéis de crescimento em todos os tratamentos: (A) Espessura dos anéis a partir da data de plantio; (B) Espessura dos anéis com todos os tratamentos iniciando a partir do ano 1; (C) Espessura acumulada dos anéis a partir da data de plantio; (D) Espessura acumulada dos anéis com todos os tratamentos iniciando a partir do ano 1

\subsection{Proporção cerne/alburno e excentricidade da medula}

Os volumes individuais médios por árvore em cada tratamento para medula, alburno, cerne e casca são apresentados na tabela 10. Todos os componentes apresentam maior volume conforme o aumento da idade da floresta, considerando-se as amostras obtidas na região do Mato Grosso. Entretanto, as porcentagens de volume da medula, do alburno e da casca diminuíram e a porcentagem do cerne aumentou, conforme a idade. Isso é corroborado por vários estudos (PÉREZ CORDERO \& KANNINEN, 2003; SANQUETTA et. al., 2014; NARAYANAN et.al., 2009; ZAHABU et. al., 2015).

Segundo Pérez Cordero \& Kanninen (2003), o diâmetro total e o diâmetro do caule do cerne variam consideravelmente entre as árvores, mesmo quando investigados em valores relativos. Para esses autores, o volume total e do cerne das árvores aumentam exponencialmente com o aumento do DAP (diâmetro a altura do peito), enquanto os teores de alburno e casca aumentam linearmente. O mesmo estudo, desenvolvido na Costa Rica, indicou que o volume de cerne aumenta quanto maior a idade e com o aumento do DAP em plantios comerciais. A figura 18 
confirma a afirmativa de Pérez Cordero \& Kanninen (2003), sendo que a correlação entre DAP e volume do cerne foi exponencial.

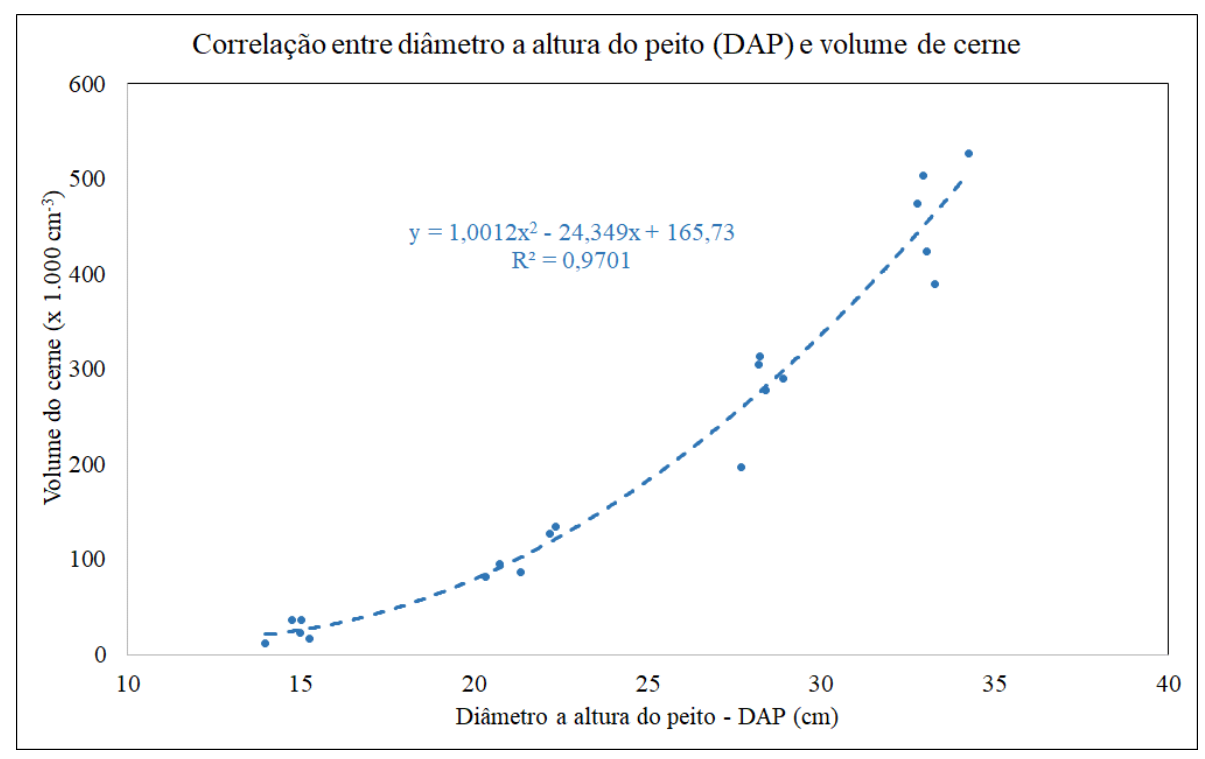

Figura 18. Correlação entre DAP e Volume do cerne para madeira de teca de três áreas e idades do MT, com 9,5; 14,4 e 18,7 anos e uma área de Angatuba/SP, com 9,4 anos de idade

No caso da floresta amostrada em Angatuba/SP, com 9,4 anos de idade, houve influência do clima da região, bem como do manejo de desbaste adotado, cuja densidade populacional inicial foi de 1.667 árvores por hectare e a população remanescente, no momento das avaliações, apresentava 950 árvores por hectare, praticamente o dobro do plantio aos 9,5 anos de idade no Mato Grosso. Com isso, a porcentagem média de alburno no povoamento do estado de São Paulo foi de 66\%, maior do que os 55,12\% correspondentes ao plantio do estado do Mato Grosso, com a mesma idade. Por outro lado, a proporção de cerne foi maior no plantio da Fazenda Mutum, 34,51\% para esse tratamento, enquanto no plantio da Fazenda Santa Maria a porcentagem foi de 24,88\% (tabela 10). Zahabu et. al. (2015), avaliaram diferentes características da madeira de teca aos 14 anos, em vários espaçamentos. Os autores encontraram proporções de cerne da madeira no espaçamento de 2 x 2 metros de 24,83\%. Nos plantios com espaçamento de $3 \times 3$ metros a proporção foi de $27,87 \%$ e no maior espaçamento (4 x 4 metros) a porcentagem de cerne foi de $31,67 \%$. Os resultados indicaram um aumento na proporção de cerne com o aumento do espaçamento de plantio, embora não tenha havido diferença estatisticamente significativa. Da mesma forma, Arce (2001) observou maior proporção de cerne em espaçamentos mais largos para plantios de teca com 10 anos de idade. Isso é corroborado por Pérez \& Kanninen (2003), que indicam que a teca cultivada com maior crescimento tem maiores porcentagens de cerne em comparação com a teca de menor desenvolvimento. 
Tabela 10. Volumes individuais médios de medula, alburno, cerne e casca calculados nas toras de teca amostradas no Mato Grosso em diferentes idades (9,5; 14,4 e 18,7 anos) e em Angatuba/SP na idade de 9,4 anos

\begin{tabular}{|c|c|c|c|c|c|c|c|c|c|c|c|}
\hline \multirow{2}{*}{ Fazenda } & \multirow{2}{*}{ Município } & \multirow{2}{*}{$\begin{array}{l}\text { Idade } \\
\text { (anos) }\end{array}$} & \multicolumn{9}{|c|}{ Volume individual médio por árvore $\left(\mathrm{cm}^{3}\right)$} \\
\hline & & & Medula & $(\%)$ & Alburno & $(\%)$ & Cerne & $(\%)$ & Casca & $(\%)$ & Total \\
\hline Sta. Maria & Angatuba/SP & 9,4 & $490,01 \mathbf{b}$ & 0,49 & $66.297,61 \mathbf{d}$ & 66,00 & $24.995,08 \mathbf{d}$ & 24,88 & $8.667,31 \mathbf{d}$ & 8,63 & $100.450,02 \mathbf{d}$ \\
\hline Mutum & Glória D’Oeste/MT & 9,5 & $874,46 \mathbf{a}$ & 0,29 & $167.422,52 \mathrm{c}$ & 55,12 & $104.836,57 \mathbf{c}$ & 34,51 & $30.620,13 \mathbf{c}$ & 10,08 & $303.753,69 \mathrm{c}$ \\
\hline Sta. Maria do Jauru & Porto Espiridião/MT & 14,4 & $925,97 \mathbf{a}$ & 0,16 & $251.035,43 \mathbf{b}$ & 43,52 & $276.769,79 \mathbf{b}$ & 47,99 & $48.045,30 \mathbf{b}$ & 8,33 & $576.776,48 \mathbf{b}$ \\
\hline Panflora & Rosário D’Oeste/MT & 18,7 & $1.095,30 \mathbf{a}$ & 0,13 & $298.804,63 \mathbf{a}$ & 36,26 & $463.686,13 \mathbf{a}$ & 56,26 & $60.528,79 \mathbf{a}$ & 7,34 & $824.114,84 \mathbf{a}$ \\
\hline
\end{tabular}

*Médias seguidas de mesma letra na vertical não diferem estatisticamente entre si, pelo teste de Tukey a $5 \%$ de probabilidade 
Zahabu et. al. (2015) concluem em seu trabalho num plantio comercial de teca de 30 anos de idade que, adotando-se o espaçamento de 4 x 4 metros espera-se alcançar no mínimo uma porcentagem de 50\% de cerne em rotações mais curtas. Pela tabela 10 e figura 19, nota-se que a porcentagem de cerne aos 18,7 anos no Mato Grosso, chega a 56,26\%. Pelo cruzamento das curvas de porcentagem de alburno e cerne na figura 19, observa-se que o valor aproximado de 50\% de cada um desses componentes é atingido por volta dos 15 anos para essas condições.

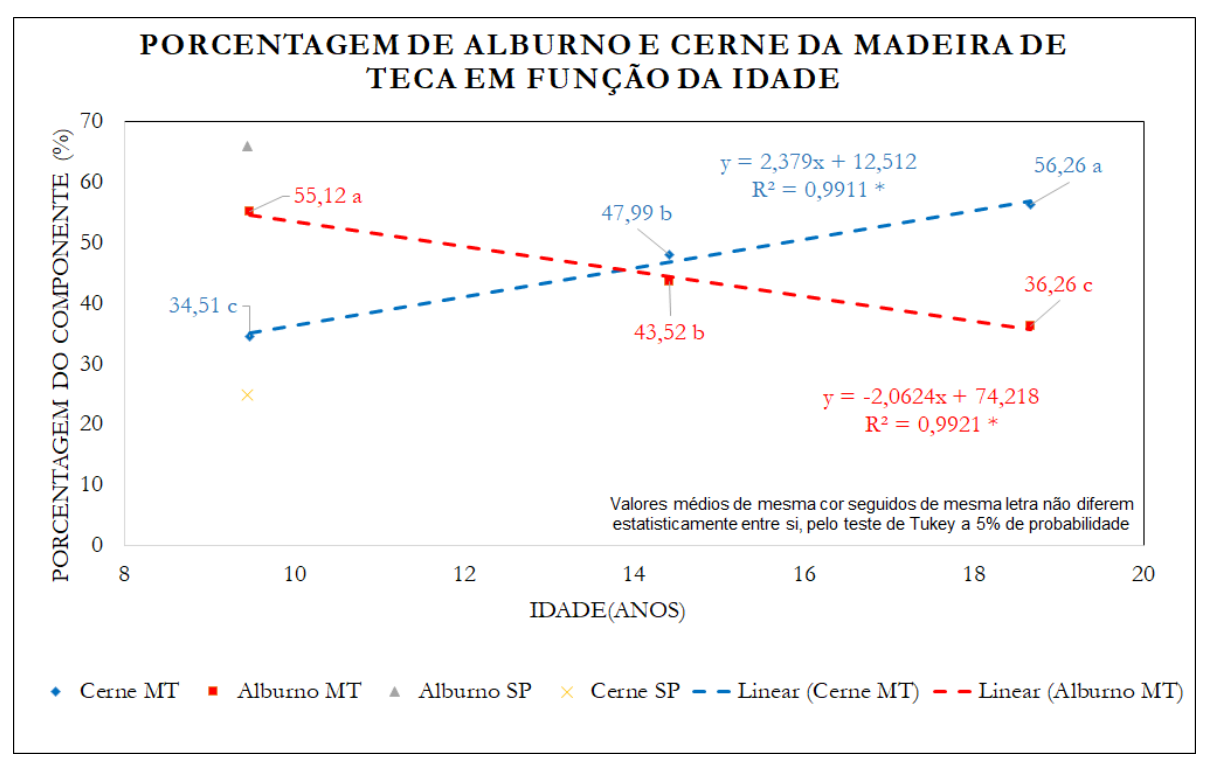

Figura 19. Porcentagem média por árvore dos componentes cerne e alburno nas toras de teca amostradas no Mato Grosso em diferentes idades (9,5; 14,4 e 18,7 anos) e em Angatuba/SP na idade de 9,4 anos

No caso de forças direcionadas às árvores de um povoamento, como vento por exemplo, o incremento de madeira nas árvores inclinadas ocorre de forma anormal, denominado como madeira de reação. Em espécies de folhosas, este lenho é designado como madeira de tração e oposta, que pode afetar a sua qualidade, sendo o principal indício a excentricidade da medula (AGUAYO et al., 2010, citado por Boschetti et. al., 2015). Segundo Boschetti et. al., 2015, quanto maior a inclinação do tronco maior a excentricidade da medula encontrada. Os valores de excentricidade da medula apresentados na tabela 11, são bastante similares a média obtida por Blanco Flórez, J. (2012). O valor médio encontrado nas árvores de teca plantada no município de Vazante/MG, no estudo desse autor, foi de $8,98 \%$, enquanto a média da excentricidade da medula encontrada para os tratamentos avaliados (tabela 11) foram de 6,22\%. Arce \& Moya (2015), também encontrou média de excentricidade muito próxima para 20 clones de teca, resultado de $8,01 \%$. 
Tabela 11. Excentricidade da medula (\%) das toras de teca amostradas no Mato Grosso em diferentes idades $(9,5 ; 14,4$ e 18,7 anos) e em Angatuba/SP na idade de 9,4 anos

\begin{tabular}{|c|c|c|c|c|c|c|c|}
\hline Fazenda & Município & $\begin{array}{l}\text { Idade } \\
\text { (anos) }\end{array}$ & $\begin{array}{c}\mathrm{No}^{\circ} \\
\text { dados }\end{array}$ & $\begin{array}{l}\text { Excentricidade } \\
\text { da medula }(\%) *\end{array}$ & $\begin{array}{c}\text { CV por árvore } \\
(\%)\end{array}$ & $\begin{array}{l}\text { Valor mínimo } \\
\text { por árvore }\end{array}$ & $\begin{array}{c}\text { Valor máximo } \\
\text { por árvore }\end{array}$ \\
\hline Santa Maria & Angatuba/SP & 9,4 & 30 & $7,40 \mathbf{a}$ & 16,10 & 3,00 & 12,88 \\
\hline Mutum & Glória D’Oeste/MT & 9,5 & 30 & $6,99 \mathbf{a}$ & 6,70 & 5,32 & 8,95 \\
\hline Santa Maria do Jauru & Porto Espiridião/MT & 14,4 & 30 & $5,35 \mathbf{b}$ & 7,21 & 4,49 & 7,87 \\
\hline Panflora & Rosário D’Oeste/MT & 18,7 & 30 & $5,14 \mathbf{b}$ & 8,82 & 3,78 & 8,15 \\
\hline
\end{tabular}

*Médias seguidas de mesma letra não diferem estatisticamente entre si, pelo teste de Tukey a 5\% de probabilidade

Por outro lado, o teste de Tukey mostrou diferença significativa entre as idades de aproximadamente 9,5 anos e as florestas mais velhas. Parece haver uma tendência de menores valores de excentricidade da medula, conforme a idade, relacionado ao crescimento e fortalecimento das árvores ao longo do tempo.

\subsection{Propriedades físicas da madeira de teca}

\subsubsection{Densidade básica}

Os valores de densidade básica da madeira para os materiais provenientes do Mato Grosso não foram diferentes significativamente entre si (tabela 12), mas o material do estado de São Paulo apresentou densidade inferior. Essa diferença pode ser explicada pelas condições climáticas e edáficas da região plantada no estado de São Paulo e pelo manejo, que diferem das outras regiões. Além disso, o plantio de Angatuba/SP sofreu duas geadas no início da sua implantação, o que pode ter influenciado tais resultados.

Motta (2011) estudou um material procedente de teca com idade de aproximadamente 15 anos, proveniente do município de Belo Oriente, M.G. e encontrou valor médio da densidade básica de $0,54 \mathrm{~g} \mathrm{~cm}^{-3}$, similar aos resultados encontrados nesse estudo para os materiais originários do Mato Grosso, com idades variando entre 9,5 e 19 anos de idade (tabela 12). Arce \& Moya (2015) realizaram a caracterização da madeira de teca para 20 diferentes clones com aproximadamente 15 anos de idade, na Província de Guanacaste, Costa Rica. A densidade básica variou de 0,45 até 0,60 $\mathrm{g} \mathrm{cm}^{-3}$. Blanco Flórez (2012) encontrou valor médio da densidade básica de madeira de teca plantada em Vazante/MG, com 13 anos de idade, de $0,527 \mathrm{~g} \mathrm{~cm}^{-3}$, também muito similar aos resultados encontrados nesse estudo para as amostras de teca do MT.

Canal (2017) não encontrou efeito significativo da idade na densidade básica da madeira de teca, que variou entre 0,50 $\mathrm{g} \mathrm{cm}^{-3}$ aos 10 anos e 0,55 $\mathrm{g} \mathrm{cm}^{-3}$ aos 16 anos. Porém, Garcia \& Marinonio (2016), concluem em seu trabalho com teca em diferentes espaçamentos, que a madeira proveniente de maior espaçamento de plantio apresentou maior densidade e maior teor de extrativos e que essas características podem estar associadas. Assim, um dos fatores que influenciaram a menor densidade básica do povoamento estudado em São Paulo, foi o manejo da floresta. Esse plantio apresenta alta população remanescente, ou seja, 950 árvores por hectare, mesmo depois dos desbastes aplicados. No caso da floresta com mesma idade implantada no Mato Grosso a população remanescente é de apenas 458 árvores por hectare. 
Tabela 12. Densidade básica $\left(\mathrm{g} \mathrm{cm}^{-3}\right)$ das amostras de toras de teca amostradas no Mato Grosso em diferentes idades (9,5; 14,4 e 18,7 anos) e em Angatuba/SP na idade de 9,4 anos

\begin{tabular}{|c|c|c|c|c|c|}
\hline Fazenda & Município & $\begin{array}{l}\text { Idade } \\
\text { (anos) }\end{array}$ & Parâmetros & $\begin{array}{c}\mathrm{N}^{0} \\
\text { dados }\end{array}$ & $\begin{array}{c}\text { Densidade básica } \\
\qquad\left(\mathrm{g} \mathrm{cm}^{-3}\right) *\end{array}$ \\
\hline \multirow{4}{*}{ Santa Maria } & \multirow{4}{*}{ Angatuba/SP } & \multirow{4}{*}{9,4} & Média & \multirow{4}{*}{10} & 0,4894 b \\
\hline & & & C.V. & & 10,60 \\
\hline & & & V. Mínimo & & 0,4358 \\
\hline & & & V. Máximo & & 0,5659 \\
\hline \multirow{4}{*}{ Mutum } & \multirow{4}{*}{ Glória D’Oeste/MT } & \multirow{4}{*}{9,5} & Média & \multirow{4}{*}{10} & 0,5584 a \\
\hline & & & C.V. & & 8,30 \\
\hline & & & V. Mínimo & & 0,4962 \\
\hline & & & V. Máximo & & 0,6228 \\
\hline \multirow{4}{*}{ Santa Maria do Jauru } & \multirow{4}{*}{ Porto Espiridião/MT } & \multirow{4}{*}{14,4} & Média & \multirow{4}{*}{10} & 0,5541 a \\
\hline & & & C.V. & & 6,33 \\
\hline & & & V. Mínimo & & 0,5060 \\
\hline & & & V. Máximo & & 0,6049 \\
\hline \multirow{4}{*}{ Panflora } & \multirow{4}{*}{ Rosário D’Oeste/MT } & \multirow{4}{*}{18,7} & Média & \multirow{4}{*}{10} & 0,5748 a \\
\hline & & & C.V. & & 4,70 \\
\hline & & & V. Mínimo & & 0,5439 \\
\hline & & & V. Máximo & & 0,6147 \\
\hline
\end{tabular}

* Médias seguidas de mesma letra não diferem estatisticamente entre si, pelo teste de Tukey a $5 \%$ de probabilidade

\subsubsection{Retratibilidade da madeira}

Os valores médios das retrações totais radial $(\varepsilon r)$, tangencial $(\varepsilon t)$, longitudinal $(\varepsilon l)$ e volumétrica $(\varepsilon v)$ determinadas em todos os tratamentos da madeira de teca foram de 1,94\%, 3,82\%, 0,28\% e 5,95\% respectivamente, o coeficiente de anisotropia foi de 1,96. Na tabela 13 são apresentados os valores médios, máximos e mínimos e coeficiente de variação para as contrações totais determinadas na madeira de teca em todos os tratamentos.

A retração radial média do material coletado em Angatuba/SP (9,4 anos de idade) foi de 2,50\%, ou seja, maior significativamente a nível de $5 \%$ de probabilidade, quando comparado com os materiais da madeira de teca do Mato Grosso, que apresentaram 1,97\%; 1,52\% e 1,78\% para as Fazendas Mutum (9,5 anos), Santa Maria do Jauru (14,4 anos) e Panflora (18,7 anos), respectivamente. Ainda assim, a menor retração foi do material coletado na Fazenda Santa Maria do Jauru. Um dos fatores que podem influenciar esse resultado seria o perfil do solo dessa propriedade, que apresenta uma camada que limita a drenagem, o que não ocorre na Fazenda Mutum e na Fazenda Santa Maria do estado de São Paulo. Essa limitação é determinada por rochas de quartzo.

A retração tangencial da madeira de teca coletada na Fazenda Santa Maria, em Angatuba, SP, também foi maior do que nos outros tratamentos, com valor de 5,79\%. Entre os materiais coletados no Mato Grosso, houve diferença significativa da retração tangencial entre a Fazenda Mutum e a Fazendas Santa Maria do Jauru.

Caracterizando a madeira de sete espécies de Eucalyptus, com idade aproximada de 16 anos, Oliveira et. al. (2010) encontraram resultados da retratibilidade radial variando de 5,0 a 9,4\%, enquanto nesse estudo a teca apresentou resultados variando de 1,52 a 2,50\%. Em termos de retratibilidade tangencial os resultados daquele autor mostraram variação de 9,3 a 15,5\%, muito maior do que a variação da teca aqui estudada que foi de 2,66 a 5,79\%. Quanto a 
retratibilidade volumétrica, as espécies de Eucalyptus estudadas por Oliveira et. al. (2010) apresentaram resultados variando de 15,9 até $27,2 \%$, enquanto o maior valor encontrado para a teca estudada foi de 8,40\%.

Roque \& Ledezma (2003), estudando o efeito do espaçamento (3 x 3 e 6 x 2 metros) sobre a densidade básica e retração da madeira, em populações de T. grandis, de 10 anos de idade, verificaram que a densidade básica foi maior no espaçamento 6 × 2 metros, enquanto que a retração volumétrica diminuiu neste espaçamento. Esse resultado corrobora o maior valor obtido para as retratibilidades estudadas no plantio de São Paulo, em função de sua maior população inicial e do manejo aplicado, que manteve essa diferença percentual em relação às árvores remanescentes, comparado com os outros tratamentos do MT.

Tabela 13. Retratibilidade radial, tangencial, axial e volumétrica e coeficiente de anisotropia (T/R) das madeiras de teca coletadas na Fazenda Santa Maria no estado de São Paulo e nas Fazendas Mutum, Santa Maria do Jauru e Panflora no estado do Mato Grosso

\begin{tabular}{|c|c|c|c|c|c|c|c|c|c|}
\hline \multirow[b]{2}{*}{ Fazenda } & \multirow[b]{2}{*}{ Município } & \multirow{2}{*}{$\begin{array}{l}\text { Idade } \\
\text { (anos) }\end{array}$} & \multirow[b]{2}{*}{ Parâmetro } & \multirow{2}{*}{$\begin{array}{c}\mathrm{N}^{\mathrm{o}} \\
\text { dados }\end{array}$} & \multicolumn{5}{|c|}{$\varepsilon$ RETRATIBILIDADE (\%) } \\
\hline & & & & & $\begin{array}{c}\mathbf{\varepsilon r} \\
\text { Radial }\end{array}$ & $\begin{array}{c}\text { et } \\
\text { Tangencial }\end{array}$ & $\varepsilon t / \varepsilon r$ & $\begin{array}{c}\text { ll } \\
\text { Longitudinal }\end{array}$ & $\begin{array}{c}\mathrm{\varepsilon V} \\
\text { Volumétrica }\end{array}$ \\
\hline \multirow{4}{*}{ Santa Maria } & \multirow{4}{*}{ Angatuba/SP } & \multirow{4}{*}{9,4} & Média & \multirow{4}{*}{60} & $2,50 \mathrm{a}$ & 5,79 a & $2,40 \mathrm{a}$ & 0,28 a & 8,40 a \\
\hline & & & C.V. & & 28,95 & 30,75 & 30,25 & 43,69 & 25,00 \\
\hline & & & V. mínimo & & 1,21 & 2,35 & 0,84 & 0,10 & 4,47 \\
\hline & & & V. máximo & & 4,16 & 8,83 & 4,61 & 0,55 & 12,39 \\
\hline \multirow{4}{*}{ Mutum } & \multirow{4}{*}{$\begin{array}{c}\text { Glória } \\
\text { D’Oeste/MT }\end{array}$} & \multirow{4}{*}{9,5} & Média & \multirow{4}{*}{60} & $1,97 \mathrm{~b}$ & $3,58 \mathrm{~b}$ & $1,83 \mathrm{~b}$ & 0,28 a & $5,75 \mathrm{~b}$ \\
\hline & & & C.V. & & 19,22 & 32,51 & 26,55 & 27,62 & 23,51 \\
\hline & & & V. mínimo & & 1,28 & 1,42 & 0,67 & 0,11 & 3,64 \\
\hline & & & V. máximo & & 2,71 & 7,08 & 3,34 & 0,48 & 9,37 \\
\hline \multirow{4}{*}{$\begin{array}{l}\text { Santa Maria } \\
\text { do Jauru }\end{array}$} & \multirow{4}{*}{$\begin{array}{c}\text { Porto } \\
\text { Espiridião/MT }\end{array}$} & \multirow{4}{*}{14,4} & Média & \multirow{4}{*}{60} & $1,52 \mathrm{c}$ & $2,66 \mathrm{c}$ & $1,79 \mathrm{~b}$ & 0,29 a & $4,41 \mathrm{c}$ \\
\hline & & & C.V. & & 23,21 & 34,67 & 30,31 & 22,46 & 25,88 \\
\hline & & & V. mínimo & & 0,44 & 1,65 & 1,01 & 0,16 & 2,50 \\
\hline & & & V. máximo & & 2,23 & 5,20 & 4,05 & 0,43 & 7,46 \\
\hline \multirow{4}{*}{ Panflora } & \multirow{4}{*}{$\begin{array}{c}\text { Rosário } \\
\text { D’Oeste/MT }\end{array}$} & \multirow{4}{*}{18,7} & Média & \multirow{4}{*}{60} & $1,78 \mathrm{~b}$ & 3,24 bc & $1,82 \mathrm{~b}$ & 0,27 a & $5,22 \mathrm{~b}$ \\
\hline & & & C.V. & & 18,78 & 33,74 & 27,28 & 32,89 & 24,38 \\
\hline & & & V. mínimo & & 1,35 & 2,04 & 1,15 & 0,07 & 3,95 \\
\hline & & & V. máximo & & 3,14 & 6,69 & 3,15 & 0,56 & 8,97 \\
\hline \multicolumn{4}{|c|}{ MÉDIA GERAL } & \multirow{4}{*}{240} & 1,94 & 3,82 & 1,96 & 0,28 & 5,95 \\
\hline \multicolumn{4}{|c|}{ C.V. } & & 30,52 & 45,63 & 31,76 & 32,56 & 35,72 \\
\hline \multicolumn{4}{|c|}{ Valor mínimo } & & 0,44 & 1,42 & 0,68 & 0,07 & 2,50 \\
\hline \multicolumn{4}{|c|}{ Valor máximo } & & 4,16 & 8,83 & 4,61 & 0,56 & 12,39 \\
\hline
\end{tabular}

*Médias seguidas de mesma letra na vertical não diferem estatisticamente entre si, pelo teste de Tukey a 5\% de probabilidade

Miranda et. al. (2011) encontraram valores médios em plantios de teca com aproximadamente 60 anos no Timor Leste de 3,50;5,17;0,49 e 7,60\% respectivamente para retratibilidade radial, tangencial, longitudinal e volumétrica.

Já Bonduelle et. al. (2015) avaliando a retratibilidade de plantios de teca no Mato Grosso com 18 anos de idade, encontraram valores similares aos obtidos nesse estudo para as amostras coletadas também no estado do Mato Grosso. A retratibilidade radial média encontrada pelos autores foi de 1,86\%, não sendo diferente significativamente entre as posições das amostras na base, no meio e no topo da árvore. O resultado médio da retratibilidade tangencial no estudo de Bonduelle et. al. (2015) foi de 4,20\% e o da retratibilidade volumétrica obteve média de 6,27\%. 
A variação da retratibilidade nas contrações radial, tangencial e longitudinal é uma das principais causas de deformação da madeira. As distorções normalmente são devidas ao encolhimento diferencial. Quando a madeira juvenil ou de reação está presente em uma borda ou face de uma tábua e a madeira normal está presente no lado oposto, a diferença em sua contração longitudinal também pode causar empenamento (SIMPSON, 1999). Segundo esse mesmo autor, a retratibilidade da madeira é afetada pela largura das fibras, espessura da parede, frequência e diâmetro dos vasos.

Andrade (2015) caracterizou a madeira de 14 espécies florestais potenciais e 13 outras espécies comerciais utilizadas para produção de pisos. Os resultados das retratibilidades radial, tangencial e volumétrica e do coeficiente de anisotropia de algumas dessas espécies mais usadas são apresentados na tabela 14, comparando-as com o valor médio desses parâmetros da teca analisada em São Paulo e Mato Grosso por esse estudo. No estudo desse autor, houve variação do resultado da retratibilidade radial de um mínimo de 3,16\% para a Itaúba amarela até um máximo de 7,10\% para a Maçaranduba. Para a retratibilidade tangencial o valor mínimo foi de 5,80\% para a Tatajuba e o máximo de 12,82\% para a Jarana amarela. Ainda, os valores de retratibilidade volumétrica variaram de 9,50\% para a Tatajuba até 19,65\% para a Jarana amarela. Comparando esses resultados de espécies já utilizadas na produção de pisos com os resultados de SP e MT (tabela 14), observamos que para a madeira plantada em Angatuba/SP, em região potencialmente não adaptada para a espécie e com manejo não adequado em termos de sistema de desbaste, encontramos valores de retratibilidade menores do que nas espécies comerciais. O mesmo se repete com os outros tratamentos.

Tabela 14. Retratibilidade radial, tangencial e volumétrica e coeficiente de anisotropia (T/R) das madeiras de algumas espécies comerciais usadas para produção de pisos, comparadas à média dos valores da teca desse estudo

\begin{tabular}{|c|c|c|c|c|c|}
\hline \multirow[b]{2}{*}{ Nome comum } & \multirow[b]{2}{*}{ Nome científico } & \multicolumn{4}{|c|}{$\varepsilon$ RETRATIBILIDADE (\%) } \\
\hline & & $\begin{array}{c}\mathbf{r} \\
\text { Radial }\end{array}$ & $\begin{array}{c}\boldsymbol{\varepsilon t} \\
\text { Tangencial }\end{array}$ & $\varepsilon t / \varepsilon r$ & Ev Volumétrica \\
\hline Teca (MT - média) & Tectona grandis & 1,76 & 3,16 & 1,81 & 5,13 \\
\hline Teca (SP) & Tectona grandis & 2,50 & 5,79 & 2,40 & 8,40 \\
\hline Amendoim & Pterogyne nitens & 3,50 & 6,50 & 1,85 & 11,00 \\
\hline Cabreúva-vermelha & Myroxylum balsamum & 4,00 & 6,70 & 1,68 & 11,00 \\
\hline Cumaru & Dipteryx odorata & 5,94 & 8,40 & 1,41 & 13,85 \\
\hline Guaiuvira & Cordia americana & 4,00 & 7,40 & 1,91 & 11,60 \\
\hline Ipê & Handroanthus serratifolius & 4,70 & 6,30 & 1,34 & 10,10 \\
\hline Jatobá & Hymenaea courbaril & 3,40 & 7,70 & 2,26 & 11,40 \\
\hline Tauari & Couratari oblongifolia & 4,20 & 6,60 & 1,57 & 10,90 \\
\hline
\end{tabular}

Fonte: Adaptado de Andrade (2015)

Por outro lado, o coeficiente anisotrópico das amostras de teca do plantio efetuado no estado de São Paulo, foi maior do que todas as espécies apresentadas na tabela 14. As amostras de madeira do estado do Mato Grosso resultaram em anisotropia menor do que as espécies Amendoim, Guaiuvira e Jatobá, que são amplamente usadas na produção de pisos. Isso demonstra o potencial da madeira de teca manejada corretamente em termos de densidade populacional e manejo de desbastes, bem como na escolha de região mais adequada para seu plantio. 


\subsubsection{Elementos anatômicos}

A madeira de teca é semiporosa, sendo o lenho inicial composto por vasos de grande diâmetro com grande volume de vazio e o lenho tardio composto por maior quantidade de material lenhoso (figura 20), ou seja, com maior quantidade de fibras com paredes espessas e vasos de menor diâmetro (GARCIA \& MARINONIO, 2016).

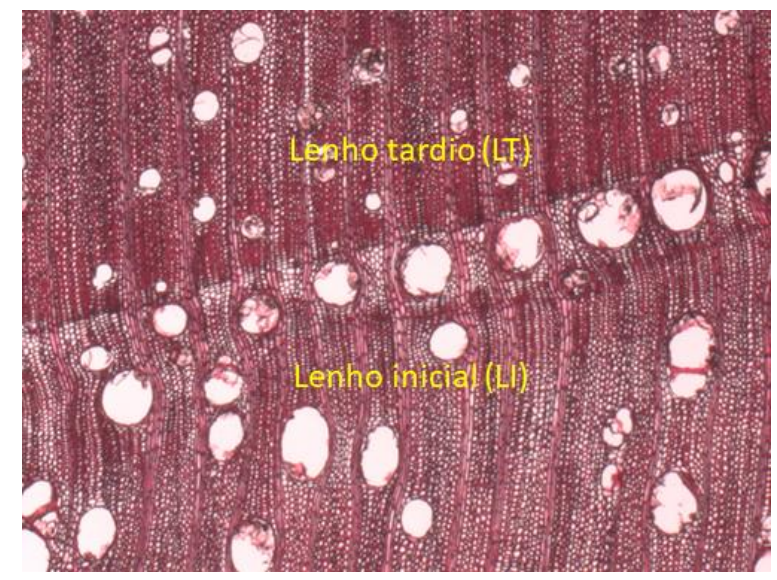

Figura 20. Corte transversal da madeira de teca de uma árvore da Fazenda Sta. Maria do Jauru, em floresta com 14,4 anos, mostrando o lenho tardio (LT) e o lenho inicial (LI)

Em termos de comprimento das fibras houve diferença significativa entre todos os tratamentos, sendo que quanto maior a idade, maior foi a média dos comprimentos desse elemento anatômico (tabela 15). Roque \& Tomazello Filho (2009), estudando a variação radial da estrutura anatômica da madeira de Gmelina concluíram que comprimento, largura e diâmetro de lúme das fibras dessa espécie são influenciados pelo clima seco ou úmido e, também pelas condições de manejo das árvores das plantações de Gmelina. Esses mesmos autores, indicam que os modelos de variação radial das dimensões das fibras, de modo geral, apresentam uma estabilidade após o sexto ano nas condições de clima tropical úmido e seco. Entretanto, pela tabela 15 observa-se um aumento apenas do comprimento das fibras quanto maior a idade das florestas, sendo que essa tendência diminui com o tempo (figura 21).

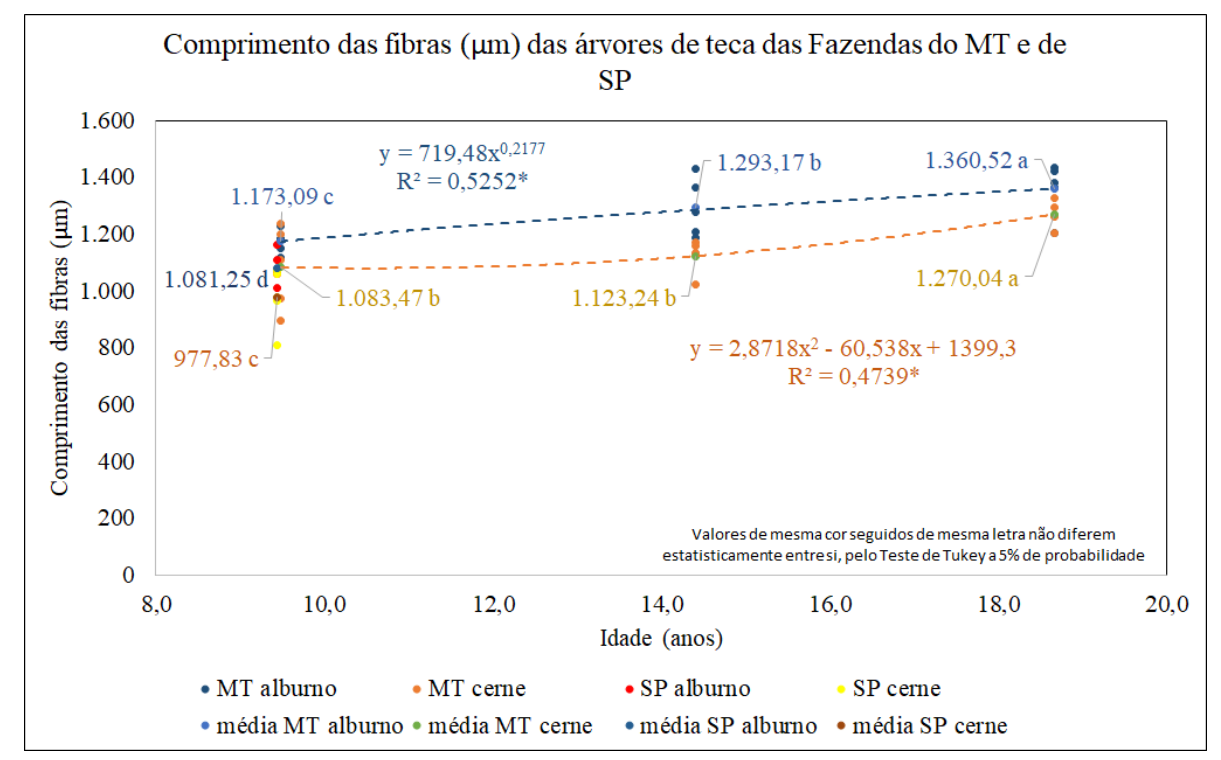

Figura 21. Comprimento das fibras $(\mu \mathrm{m})$ das árvores de teca das Fazendas do MT e de SP 
Há diferença significativa entre as médias dos comprimentos das fibras nas amostras com idades similares, mas plantadas em regiões e manejo diferentes. As árvores da floresta de Angatuba/SP, com 9,4 anos, apresentaram média do comprimento das fibras de 1.081,26 $\mu \mathrm{m}$ e a média da Fazenda Mutum, com floresta de 9,5 anos, foi de 1.173,09 $\mu \mathrm{m}$. Essa diferença ocorreu em função da densidade populacional inicial maior na Fazenda de SP, bem como pelas diferenças climáticas, conforme estudo já citado de Roque \& Tomazello Filho (2009), que indicam a influência de clima e manejo nas dimensões dos elementos anatômicos.

Moya et. al. (2009) estudaram a influência de diferentes sítios sobre as dimensões de elementos anatômicos em teca e encontrou variações das dimensões das fibras que oscilaram de 0,70 a 1,60 mm para o comprimento, entre 21 e $29 \mu \mathrm{m}$ para o diâmetro e entre 11 e $20 \mu \mathrm{m}$ para o diâmetro do lúme e a espessura da parede celular variou de 3,2 a 5,7 $\mu \mathrm{m}$. Esses valores corroboram os resultados obtidos na tabela 15, para esses parâmetros. Chagas et. al. (2014), encontraram comprimento de fibras em plantios de teca com 4, 6 e 12 anos, plantados em Santo Antônio do Leverger/MG, variando de 0,93 a 1,12 mm, largura das fibras de 20,87 até 24,35 $\mu \mathrm{m}$ e o diâmetro de 4,32 a 4,79 $\mu \mathrm{m}$, com diferenças significativas entre as idades, mas sem uma tendência crescente ou decrescente dos valores.

Houve diferença significativa entre o comprimento das fibras coletadas no cerne e no alburno, tendo esse último componente uma média maior do que os valores obtidos no cerne (tabela 15). Lima et. al. (2011) compararam os resultados das dimensões anatômicas da madeira de um plantio de 31 anos de Tectona grandis. Houve diferença significativa nas posições radiais do comprimento das fibras, sendo maior próxima a casca e reduzindo na direção da medula. Por outro lado, Gonçalves et al. (2007) constataram, em amostra de T. grandis em floresta plantada no estado de São Paulo com 12 anos de idade e no Espírito Santo com 3 anos de idade, que independentemente dos locais, ocorrem variação na densidade básica e das dimensões das fibras de teca, de forma crescente no sentido medula-casca, podendo essas variações serem estabilizadas na madeira proveniente de árvores mais velhas. Essa tendência de variação observada no sentido medula-casca, possivelmente marca o término do lenho juvenil e o início do lenho adulto. De forma indireta, essa tendência pode ser observada na diferença significativa entre as médias de comprimento das fibras coletadas no alburno e no cerne para os tratamentos avaliados. O material de alburno pode representar uma coleta mais próxima da casca, enquanto o material retirado do cerne representaria uma coleta de fibras na região em direção à medula. O que comprova o maior valor das fibras do alburno (tabela 15). 
Tabela 15. Comprimento, largura total, largura do lúme e espessura da parede das fibras da teca amostrada no Mato Grosso em diferentes idades (9,5; 14,4 e 18,7 anos) e em Angatuba/SP na idade de 9,4 anos

\begin{tabular}{|c|c|c|c|c|c|c|c|c|c|c|c|}
\hline \multirow[b]{2}{*}{ Fazenda } & \multirow[b]{2}{*}{ Município } & \multirow[b]{2}{*}{$\begin{array}{l}\text { Idade } \\
\text { (anos) }\end{array}$} & \multirow[b]{2}{*}{ Componente } & \multicolumn{8}{|c|}{ FIBRAS } \\
\hline & & & & $\begin{array}{c}\text { No } \\
\text { dados }\end{array}$ & $\begin{array}{c}\text { Comprimento } \\
(\mu \mathrm{m})\end{array}$ & $\begin{array}{l}\mathrm{N}^{\circ} \\
\text { dados }\end{array}$ & $\begin{array}{c}\text { Diâmetro } \\
\text { total } \\
(\mu \mathrm{m})\end{array}$ & $\begin{array}{c}\mathrm{N}^{\circ} \\
\text { dados }\end{array}$ & $\begin{array}{l}\text { Diâmetro } \\
\text { lúme }(\mu \mathrm{m})\end{array}$ & $\begin{array}{c}\mathbf{N}^{\circ} \\
\text { dados }\end{array}$ & $\begin{array}{c}\text { Espessura } \\
\text { parede } \\
(\mu \mathrm{m})\end{array}$ \\
\hline Santa Maria & Angatuba/SP & 9,4 & Alburno & 250 & $\begin{array}{c}\mathbf{1 . 0 8 1 , 2 6 \mathrm { d }} \\
\text { CV } 14,87 \% \\
\text { V Máx 1.757,05 } \\
\text { V Mín } 742,28 \\
\end{array}$ & 50 & $\begin{array}{c}\mathbf{2 6 , 0 8} \text { a } \\
\text { CV } 17,61 \% \\
\text { V Máx } 35,3 \\
\text { V Mín } 15,4\end{array}$ & 50 & $\begin{array}{c}\mathbf{1 7 , 7 4} \text { a } \\
\text { CV 22,44\% } \\
\text { V Máx } 25,1 \\
\text { V Mín 9,6 }\end{array}$ & 50 & $\begin{array}{c}4,17 \text { a } \\
\text { CV 14,47\% } \\
\text { V Máx 6,2 } \\
\text { V Mín 2,6 }\end{array}$ \\
\hline Mutum & $\begin{array}{c}\text { Glória } \\
\text { D’Oeste/MT }\end{array}$ & 9,5 & Alburno & 250 & $\begin{array}{c}\mathbf{1 . 1 7 3 , 0 9} \text { c } \\
\text { CV 14,83\% } \\
\text { V. Máx 1.664,26 } \\
\text { V. Mín 708,58 }\end{array}$ & 50 & $\begin{array}{c}\mathbf{2 8 , 0 1} \text { a } \\
\text { CV 16,74\% } \\
\text { V Máx } 38,0 \\
\text { V Mín } 15,0\end{array}$ & 50 & $\begin{array}{c}19,01 \text { a } \\
\text { CV 22,63\% } \\
\text { V Máx } 30,3 \\
\text { V Mín } 8,2\end{array}$ & 50 & $\begin{array}{c}4,46 \text { a } \\
\text { CV 12,77\% } \\
\text { V Máx 6,1 } \\
\text { V Mín 3,1 }\end{array}$ \\
\hline $\begin{array}{l}\text { Santa Maria } \\
\text { do Jauru }\end{array}$ & $\begin{array}{c}\text { Porto } \\
\text { Espiridião/MT }\end{array}$ & 14,4 & Alburno & 250 & $\begin{array}{c}\mathbf{1 . 2 9 3 , 1 7 b} \text { b } \\
\text { CV 14,42\% } \\
\text { V Máx 1.834,07 } \\
\text { V. Mín 732,17 }\end{array}$ & 50 & $\begin{array}{c}\text { 27,49 a } \\
\text { CV 19,72\% } \\
\text { V Máx } 46,8 \\
\text { V Mín } 17,7\end{array}$ & 50 & $\begin{array}{c}\mathbf{1 8 , 6 5} \text { a } \\
\text { CV 26,93\% } \\
\text { V Máx 35,7 } \\
\text { V Mín 10,9 }\end{array}$ & 50 & $\begin{array}{c}\text { 4,42 a } \\
\text { CV 12,11\% } \\
\text { V Máx 5,8 } \\
\text { V Mín } 3,2\end{array}$ \\
\hline Panflora & $\begin{array}{c}\text { Rosário } \\
\text { D’Oeste/MT }\end{array}$ & 18,7 & Alburno & 250 & $\begin{array}{c}\mathbf{1 . 3 6 0 , 5 3} \text { a } \\
\text { CV } 12,85 \% \\
\text { V Máx } 1.993,06 \\
\text { V Mín 805,62 } \\
\end{array}$ & 50 & $\begin{array}{c}\mathbf{2 7 , 9 0} \text { a } \\
\text { CV 20,22\% } \\
\text { V Máx } 39,4 \\
\text { V Mín } 13,4 \\
\end{array}$ & 50 & $\begin{array}{c}\mathbf{1 9 , 0 8} \text { a } \\
\text { CV 24,58\% } \\
\text { V Máx } 27,5 \\
\text { V Mín 7,8 } \\
\end{array}$ & 50 & $\begin{array}{c}\text { 4,41 a } \\
\text { CV 16,38\% } \\
\text { V Máx 6,0 } \\
\text { V Mín 2,6 } \\
\end{array}$ \\
\hline & MÉDIA AL & URNO & & 1.000 & $1.227,011 \mathrm{a}$ & 200 & $27,37 \mathbf{a}$ & 200 & $18,64 \mathrm{a}$ & 200 & $4,37 \mathrm{a}$ \\
\hline Santa Maria & Angatuba/SP & 9,4 & Cerne & 250 & $\begin{array}{c}977,83 \mathrm{c} \\
\text { CV } 14,54 \% \\
\text { V Máx 1.620,69 } \\
\text { V Mín 563,41 }\end{array}$ & 50 & $\begin{array}{c}\mathbf{2 5 , 0 1 ~ b} \\
\text { CV 15,93\% } \\
\text { V Máx 35,5 } \\
\text { V Mín } 17,2\end{array}$ & 50 & $\begin{array}{c}17,22 \text { a } \\
\text { CV 20,42\% } \\
\text { V Máx } 28,0 \\
\text { V Mín 10,0 }\end{array}$ & 50 & $\begin{array}{c}3,90 \text { b } \\
\text { CV 14,13\% } \\
\text { V Máx 5,1 } \\
\text { V Mín 2,5 }\end{array}$ \\
\hline Mutum & $\begin{array}{c}\text { Glória } \\
\text { D’Oeste/MT }\end{array}$ & 9,5 & Cerne & 250 & $\begin{array}{c}\mathbf{1 . 0 8 3 , 4 7 ~ b} \\
\text { CV } 15,99 \% \\
\text { V Máx } 1.834,07 \\
\text { V Mín } 732,17 \\
\end{array}$ & 50 & $\begin{array}{c}\mathbf{2 5 , 5 2} \text { ab } \\
\text { CV 18,91\% } \\
\text { V Máx 39,5 } \\
\text { V Min 13,5 }\end{array}$ & 50 & $\begin{array}{c}\mathbf{1 7 , 0 3} \text { a } \\
\text { CV } 24,27 \% \\
\text { V Máx } 30,9 \\
\text { V Mín 7,3 } \\
\end{array}$ & 50 & $\begin{array}{c}\text { 4,25 a } \\
\text { CV 13,54\% } \\
\text { V Máx 5,5 } \\
\text { V Mín 2,9 } \\
\end{array}$ \\
\hline $\begin{array}{l}\text { Santa Maria } \\
\text { do Jauru }\end{array}$ & $\begin{array}{c}\text { Porto } \\
\text { Espiridião/MT }\end{array}$ & 14,41 & Cerne & 250 & $\begin{array}{c}\mathbf{1 . 1 2 3 , 2 4} \text { b } \\
\text { CV 17,29\% } \\
\text { V Máx 1.657,01 } \\
\text { V Mín 674,87 }\end{array}$ & 50 & $\begin{array}{c}\mathbf{2 6 , 6 0} \text { ab } \\
\text { CV 16,06\% } \\
\text { V Máx 34,8 } \\
\text { V Mín 16,5 }\end{array}$ & 50 & $\begin{array}{c}17,70 \text { a } \\
\text { CV 23,34\% } \\
\text { V Máx } 25,8 \\
\text { V Mín } 8,7\end{array}$ & 50 & $\begin{array}{c}\text { 4,45 a } \\
\text { CV 12,83\% } \\
\text { V Máx 5,5 } \\
\text { V Mín 3,2 }\end{array}$ \\
\hline Panflora & $\begin{array}{c}\text { Rosário } \\
\text { D’Oeste/MT }\end{array}$ & 18,7 & Cerne & 250 & $\begin{array}{c}\mathbf{1 . 2 7 0 , 0 4} \text { a } \\
\text { CV } 15,44 \% \\
\text { V Máx } 1824,29 \\
\text { V Mín } 773,86 \\
\end{array}$ & 50 & $\begin{array}{c}\mathbf{2 7 , 7 8} \text { a } \\
\text { CV 16,41\% } \\
\text { V Máx } 39,5 \\
\text { V Mín } 14,3 \\
\end{array}$ & 50 & $\begin{array}{c}\mathbf{1 9 , 1 0} \text { a } \\
\text { CV 21,84\% } \\
\text { V Máx 28,5 } \\
\text { V Mín 8,5 } \\
\end{array}$ & 50 & $\begin{array}{c}\text { 4,34 a } \\
\text { CV 11,04\% } \\
\text { V Máx 5,9 } \\
\text { V Mín 2,9 } \\
\end{array}$ \\
\hline & MÉDIA C & $\mathrm{NE}$ & & 1.000 & $1.113,65 \mathrm{~b}$ & 200 & $26,23 \mathrm{~b}$ & 200 & $17,76 \mathrm{a}$ & 200 & $4,23 \mathrm{~b}$ \\
\hline
\end{tabular}

*Médias seguidas de mesma letra, com a mesma cor e na mesma coluna e componente não diferem entre si, pelo teste de Tukey a 5\% de probabilidade 
Canal (2017), estudando madeiras de teca em plantios com 10, 14 e 17 anos, verificou que não ocorreram correlações significativas entre comprimento, diâmetro do lúme e frequência de vasos com a idade. Provavelmente, porque esse autor utilizou plantios com idades superiores a 10 anos e outros indicam aumento das dimensões anatômicas até o o sexto ano (ROQUE \& TOMAZELLO FILHO, 2009) e entre quinto e o sétimo ano (MOYA et. al., 2009). Portanto, isso concorda com o comportamento das dimensões anatômicas dos vasos nos tratamentos avaliados nesse estudo, que apresentam idades superiores a 9 anos (tabela 16).

Tabela 16. Comprimento e largura dos vasos da teca amostrada no Mato Grosso em diferentes idades (9,5; 14,4 e 18,7 anos) e em Angatuba/SP na idade de 9,4 anos

\begin{tabular}{|c|c|c|c|c|c|c|c|}
\hline \multirow[b]{2}{*}{ Fazenda } & \multirow[b]{2}{*}{ Município } & \multirow{2}{*}{$\begin{array}{l}\text { Idade } \\
\text { (anos) }\end{array}$} & \multirow[b]{2}{*}{ Componente } & \multicolumn{4}{|c|}{ VASOS } \\
\hline & & & & $\begin{array}{c}\mathrm{No}^{\circ} \\
\text { dados }\end{array}$ & $\begin{array}{c}\text { Comprimento } \\
(\mu \mathrm{m})\end{array}$ & $\begin{array}{c}\text { Diâmetro } \\
(\mu \mathrm{m})\end{array}$ & $\begin{array}{l}\text { Frequência } \\
\left(n^{o} \mu m^{-2}\right)\end{array}$ \\
\hline \multirow{4}{*}{ Santa Maria } & \multirow{4}{*}{ Angatuba/SP } & \multirow{4}{*}{9,4} & \multirow{4}{*}{ alburno } & \multirow{4}{*}{50} & 286,08 a & $170,15 \mathrm{a}$ & $4,89 \mathrm{ab}$ \\
\hline & & & & & CV 21,97\% & CV $18,67 \%$ & CV $14,32 \%$ \\
\hline & & & & & V Máx 397,85 & V Máx 242,53 & V Máx 8,14 \\
\hline & & & & & V Mín 194,14 & V Mín 103,11 & V Mín 2,62 \\
\hline \multirow{4}{*}{ Mutum } & \multirow{4}{*}{$\begin{array}{c}\text { Glória } \\
\text { D’Oeste/MT }\end{array}$} & \multirow{4}{*}{9,5} & \multirow{4}{*}{ alburno } & \multirow{4}{*}{50} & 273,79 a & $165,10 \mathrm{a}$ & $4,07 \mathrm{~b}$ \\
\hline & & & & & CV 23,29\% & CV 23,03\% & CV $26,83 \%$ \\
\hline & & & & & V Máx 356,43 & V Máx 207,17 & V Máx 7,06 \\
\hline & & & & & V Mín 166,12 & V Mín 100,91 & V Mín 2,08 \\
\hline \multirow{4}{*}{ Santa Maria do Jauru } & \multirow{4}{*}{$\begin{array}{l}\text { Porto } \\
\text { Espiridião/MT }\end{array}$} & \multirow{4}{*}{14,4} & \multirow{4}{*}{ alburno } & \multirow{4}{*}{50} & 295,53 a & 164,78 a & 5,87 a \\
\hline & & & & & CV $16,53 \%$ & CV $32,39 \%$ & CV $42,22 \%$ \\
\hline & & & & & V Máx 377,20 & V Máx 242,57 & V Máx 10,66 \\
\hline & & & & & V Mín 221,24 & V Mín 96,47 & V Mín 3,40 \\
\hline \multirow{4}{*}{ Panflora } & \multirow{4}{*}{$\begin{array}{c}\text { Rosário } \\
\text { D’Oeste/MT }\end{array}$} & \multirow{4}{*}{18,7} & \multirow{4}{*}{ alburno } & \multirow{4}{*}{50} & 295,79 a & 183,03 a & $4,90 \mathrm{ab}$ \\
\hline & & & & & CV $19,09 \%$ & CV 33,16\% & CV $23,75 \%$ \\
\hline & & & & & V Máx 383,76 & V Máx 270,08 & V Máx 7,45 \\
\hline & & & & & V Mín 203,64 & V Mín 101,39 & V Mín 3,10 \\
\hline & MÉDIA ALBI & & & 200 & 287,80 a & $170,77 \mathrm{a}$ & $4,93 \mathrm{a}$ \\
\hline \multirow{4}{*}{ Santa Maria } & \multirow{4}{*}{ Angatuba/SP } & & & & 279,09 a & $169,04 \mathrm{a}$ & $4,66 \mathrm{a}$ \\
\hline & & 04 & n & 50 & CV $21,05 \%$ & CV $22,74 \%$ & CV 20,20\% \\
\hline & & J,4 & elnite & J & V Máx 368,147 & V Máx 246,57 & V Máx 8,41 \\
\hline & & & & & V Mín 193,154 & V Mín 91,45 & V Mín 3,06 \\
\hline & & & & & 296,69 a & 155,86 a & $4,85 \mathrm{a}$ \\
\hline Sutm & Glória & 0.5 & come & 0 & CV 16,77\% & CV 23,98\% & CV 17,99\% \\
\hline 18 & D’Oeste/MT & ני, & (eniाi & 0 & V Máx 378,779 & V Máx 228,69 & V Máx 7,38 \\
\hline & & & & & V Mín 203,450 & V Mín 91,08 & V Mín 3,44 \\
\hline & & & & & 278,95 a & 155,24 a & $5,23 \mathrm{a}$ \\
\hline & Porto & & & & CV 21,24\% & CV $22,32 \%$ & CV $16,73 \%$ \\
\hline & Espiridião/MT & 年 & (е) & & V Máx 357,856 & V Máx 220,33 & V Máx 7,39 \\
\hline & & & & & V Mín 191,831 & V Mín 106,38 & V Mín 3,48 \\
\hline & & & & & 302,82 a & $163,63 \mathrm{a}$ & $4,90 \mathrm{a}$ \\
\hline D & Rosário & & & & CV 18,62\% & CV 30,51\% & CV 19,66\% \\
\hline & D’Oeste/MT & & & & V Máx 372,784 & V Máx 233,96 & V Máx 7,50 \\
\hline & & & & & V Mín 206,875 & V Mín 107,03 & V Mín 2,98 \\
\hline & MÉDIA CE & & & 200 & 289,39 a & $160,94 \mathrm{a}$ & $4,91 \mathrm{a}$ \\
\hline
\end{tabular}

*Médias seguidas de mesma letra, com a mesma cor e na mesma coluna e componente não diferem estatisticamente entre si, pelo teste de Tukey a 5\% de probabilidade 
Entre todos os tratamentos avaliados, o diâmetro médio dos vasos em lenhos tardios foi de 131,19 $\mu \mathrm{m}$, enquanto a média dos lenhos iniciais foi de 200,52 $\mu \mathrm{m}$. Essa diferença é corroborada por Josue \& Imiyabir (2011), que encontraram valores de 228 e $112 \mu \mathrm{m}$, respectivamente para os anéis iniciais e tardios em plantios de 15 anos de idade na região de Sabah. Motta (2011), estudando plantios de teca com 15 anos em Belo Oriente/MG, observou que os elementos vasculares atingiram diâmetro tangencial que variaram de pequenos $(50,85 \mu \mathrm{m})$ a grandes $(296,63 \mu \mathrm{m})$, com predominância de poros médios $(161,26 \mu \mathrm{m})$.

\subsubsection{Química da madeira (extrativos)}

A madeira de teca é conhecida por sua alta durabilidade natural à organismos destruidores de madeira, em função de sua quantidade e tipo de extrativo (BHAT et al. 2003). No cerne o conteúdo extrativo total varia de $10 \%$ a um máximo de 19,8\% (THULASIDAS \& BHAT, 2012).

Segundo Silva \& Trugilho (2003) a diferença entre os valores de extrativos em diferentes idades se deve à intensificação do envelhecimento e morte das células de parênquima com o avanço da idade das árvores. Nesse processo de morte das células, Micco et al. (2016) consideram que ocorre elevada produção de extrativos e impregnação desses compostos nas paredes das fibras e lume dos demais elementos anatômicos da madeira. Esses estudos corroboram os resultados apresentados na tabela 17 e figura 22, que mostram a tendência de aumento da concentração de extrativos, conforme a idade do povoamento de teca.

Vários autores ressaltam a importância do conteúdo de extrativos na durabilidade natural da madeira de teca, que está relacionado a quantidade de tectoquinona, substância de origem aromática presente em algumas espécies de verbenáceas, que confere propriedades antifúngicas, bactericidas e repelentes ao ataque de insetos (WINDEISEN et. al, 2003; THULASIDAS \& BAILLÈRES, 2017). Os menores valores das concentrações de extrativos encontrados nos plantios mais novos desse estudo (tabela 17) indicam que o uso dessa madeira para pisos ou decks deve-se limitar a condições internas, sem a influência de raios ultravioletas ou da ação da umidade das chuvas. Outra possibilidade de uso seria como base para pisos engenheirados.

Tabela 17. Concentração de extrativos (\%) das amostras de madeira de teca coletadas no Mato Grosso em diferentes idades (9,5; 14,4 e 18,7 anos) e em Angatuba/SP na idade de 9,4 anos

\begin{tabular}{|c|c|c|c|c|c|c|c|}
\hline Fazenda & Município & $\begin{array}{l}\text { Idade } \\
\text { (anos) }\end{array}$ & $\begin{array}{c}\text { No } \\
\text { dados }\end{array}$ & $\begin{array}{c}\text { Concentração } \\
\text { extrativos } \\
(\%)\end{array}$ & $\begin{array}{l}\text { CV } \\
(\%)\end{array}$ & $\begin{array}{c}\text { Valor } \\
\text { mínimo }\end{array}$ & $\begin{array}{c}\text { Valor } \\
\text { máximo }\end{array}$ \\
\hline Santa Maria & Angatuba/SP & 9,4 & 15 & $7,69 \mathbf{b}$ & 23,04 & 5,21 & 9,73 \\
\hline Mutum & Glória D’Oeste/MT & 9,5 & 15 & $8,76 \mathbf{b}$ & 12,42 & 6,97 & 9,69 \\
\hline Santa Maria do Jauru & Porto Espiridião/MT & 14,4 & 15 & $11,17 \mathbf{a}$ & 12,96 & 9,79 & 12,80 \\
\hline Panflora & Rosário D’Oeste/MT & 18,7 & 15 & $11,54 \mathbf{a}$ & 8,10 & 10,47 & 12,68 \\
\hline
\end{tabular}

*Médias seguidas de mesma letra não diferem estatisticamente entre si, pelo teste de Tukey a 5\% de probabilidade

Polato et. al. (2005), estudando madeira de teca no Brasil em florestas com 14 e 22 anos, encontraram conteúdos totais de extrativos no cerne variando de 7,8 até 11,9\%. A extração de ciclohexano-etanol foi a maior fração encontrada de extrativos na madeira. Segundo esse autor, essa fração incluiu ácidos graxos, ácidos resínicos, ceras taninos e matéria corante. 


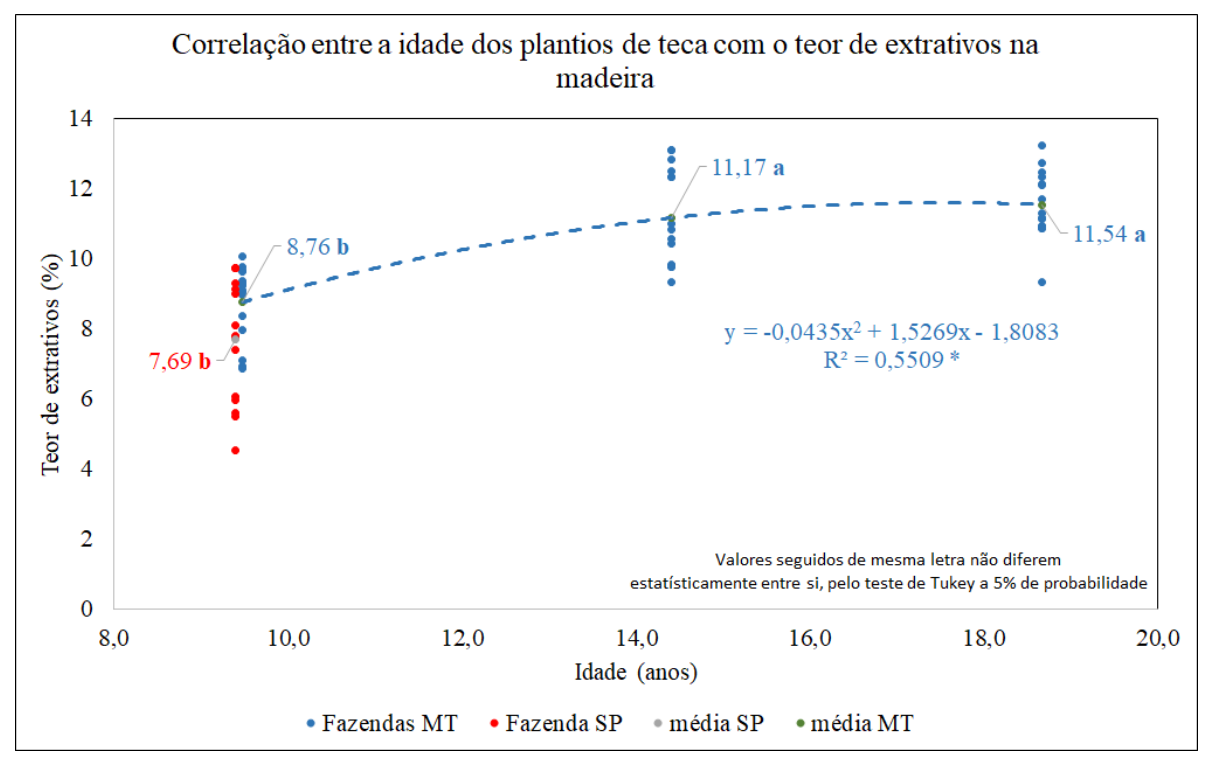

Figura 22. Correlação entre idade (anos) e o teor de extrativos (\%) de teca nos tratamentos do Mato Grosso e em São Paulo, nas idades de 9,4; 9,5; 14,4 e 18,7 anos

\subsection{Propriedades mecânicas da madeira de teca}

As propriedades físicas e mecânicas superiores da teca, sua alta durabilidade, sua estabilidade dimensional e aparência estética torna essa madeira adequada para uma enorme variedade de usos finais, como construções pesadas, móveis e gabinetes, construção de embarcações e carrocerias de caminhões, marcenaria e produtos de madeira reconstituída (THULASIDAS \& BHAT, 2012).

Em termos de propriedades mecânicas da madeira o Módulo de Ruptura (MOR) e o Módulo de Elasticidade (MOE) são dois parâmetros de grande relevância na caracterização tecnológica da madeira; ambos fornecem uma boa aproximação da resistência do material (PINTO, 2007).

A madeira de teca amostrada no estado de São Paulo, com menor idade e condições climáticas menos adequada para o plantio da espécie tem apresentado resistência reduzida com menor densidade da madeira (tabela 12, 16, 17, 18 e 19), fato corroborado por Senft et. al. (1986). Esses autores também relataram que a idade de maturação da teca está em torno de 20 a 25 anos. Há evidências suficientes de diferentes partes do mundo para mostrar que a teca de pequena dimensão cultivada comercialmente não é inferior a teca natural em termos de densidade, resistência e estabilidade dimensional (BHAT et al., 2003; THULASIDAS \& BHAT, 2012). A teca pode atingir propriedades ótimas de resistência aos 21 anos de idade, conforme registrado em Nilambur, Índia (BHAT et al., 2003).

O estudo do perfil do solo demonstra que as Fazendas Panflora e Santa Maria do Jauru têm em comum uma camada que limita a drenagem do solo, fato que não ocorre na Fazenda Mutum. No caso da Panflora são concreções de óxido de ferro que impedem a drenagem, enquanto na Fazenda Santa Maria do Jauru são rochas de quartzo. Essa restrição pode afetar a dinâmica hídrica do solo, ou seja, a disponibilidade de água ao final da estação chuvosa e excesso de água no pico das águas. Essas variações podem fazer com que a teca adote algum mecanismo, que influencie a formação da madeira e, consequentemente algumas propriedades da madeira. 


\subsubsection{Resistência ao cisalhamento}

Em termos de resistência ao cisalhamento, tanto no plano tangencial, quanto radial, não houve diferença significativa entre os tratamentos das Fazendas do Mato Grosso, mesmo em diferentes idades (tabela 18). Apenas a madeira amostrada na Fazenda Santa Maria em Angatuba/SP apresentou menor resistência nesse parâmetro.

Josue \& Imiyabir (2011), estudando as características da madeira de teca em um plantio de 15 anos plantado em Sabah na Malásia, encontraram valores médios de resistência ao cisalhamento (madeira seca ao ar) de 18,6 e 16,4 $\mathrm{MPa}$, respectivamente para os resultados do plano tangencial e radial. Apesar dos valores serem maiores do que os apresentados nesse estudo, o plantio do Mato Grosso com 18,7 anos de idade apresentou resultados pouco inferiores. Por outro lado, resultados de apenas 12,26 MPa para cisalhamento, em madeira coletada em plantios de 15 anos foram encontrados na região de Belo Oriente, MG (MOTTA, 2011). Esses valores são similares aos encontrados nos plantios com 9,4 anos em Angatuba/SP.

Outro estudo, realizado em Jangada e Cáceres/MT, com plantios de 5, 10 e 30 anos de teca, indicou uma tendência de maiores valores em plantios mais velhos para o cisalhamento, sendo 11,07; 11,79 e 13,37, respectivamente para as idades de 5, 10 e 30 anos (PINTO, 2007). Apesar de não ter havido diferença significativa entre a resistência ao cisalhamento nos planos tangencial e radial, existe uma tendência de maiores valores no plano tangencial, o que é repetido no estudo de Josue \& Imiyabir (2011).

Tabela 18. Resistência ao cisalhamento $12 \%$ das madeiras de teca coletadas na Fazenda Santa Maria no estado de São Paulo e nas Fazendas Mutum, Santa Maria do Jauru e Panflora no estado do Mato Grosso

\begin{tabular}{|c|c|c|c|c|c|c|c|}
\hline \multirow{2}{*}{ Fazenda } & \multirow{2}{*}{ Município } & \multirow{2}{*}{$\begin{array}{l}\text { Idade } \\
\text { (anos) }\end{array}$} & \multirow{2}{*}{ Parâmetro } & \multirow{2}{*}{$\begin{array}{c}\mathrm{No}^{\circ} \\
\text { dados }\end{array}$} & \multicolumn{3}{|c|}{ Cisalhamento $12 \%$ (MPa) } \\
\hline & & & & & tangencial & radial & média \\
\hline \multirow{4}{*}{ Santa Maria } & \multirow{4}{*}{ Angatuba/SP } & \multirow{4}{*}{9,4} & Média & \multirow{4}{*}{50} & $13,25 \mathrm{~b}$ & $12,29 \mathrm{~b}$ & $12,77 \mathrm{~b}$ \\
\hline & & & C.V. & & 11,87 & 7,98 & 9,80 \\
\hline & & & V. mínimo & & 10,73 & 10,54 & 10,64 \\
\hline & & & V. máximo & & 14,96 & 12,86 & 13,87 \\
\hline \multirow{4}{*}{ Mutum } & \multirow{4}{*}{ Glória D’Oeste/MT } & \multirow{4}{*}{9,5} & Média & \multirow{4}{*}{50} & 16,94 a & 15,86 a & $16,40 \mathrm{a}$ \\
\hline & & & C.V. & & 8,63 & 10,32 & 9,27 \\
\hline & & & V. mínimo & & 15,23 & 13,38 & 14,30 \\
\hline & & & V. máximo & & 19,13 & 17,93 & 18,53 \\
\hline \multirow{4}{*}{ Santa Maria do Jauru } & \multirow{4}{*}{ Porto Espiridião/MT } & \multirow{4}{*}{14,4} & Média & \multirow{4}{*}{50} & $15,20 \mathrm{ab}$ & $13,46 \mathrm{ab}$ & $14,33 \mathrm{ab}$ \\
\hline & & & C.V. & & 9,44 & 7,97 & 8,41 \\
\hline & & & V. mínimo & & 13,85 & 12,20 & 13,02 \\
\hline & & & V. máximo & & 17,09 & 14,85 & 15,97 \\
\hline \multirow{4}{*}{ Panflora } & \multirow{4}{*}{ Rosário D’Oeste/MT } & \multirow{4}{*}{18,7} & Média & \multirow{4}{*}{50} & 17,17 a & 15,66 a & 16,41 a \\
\hline & & & C.V. & & 14,35 & 14,03 & 13,94 \\
\hline & & & V. mínimo & & 14,30 & 13,62 & 14,24 \\
\hline & & & V. máximo & & 19,70 & 18,07 & 18,86 \\
\hline \multicolumn{3}{|c|}{ MÉDIA GERAL } & & \multirow{4}{*}{200} & $15,64 \mathrm{~A}$ & $14,32 \mathrm{~A}$ & $14,98 \mathrm{~A}$ \\
\hline \multicolumn{3}{|c|}{ C.V. } & & & 14,70 & 14,65 & 14,46 \\
\hline \multicolumn{4}{|c|}{ Valor mínimo } & & 10,73 & 10,54 & 10,64 \\
\hline & Valor máximo & & & & 19,70 & 18,07 & 18,86 \\
\hline
\end{tabular}

*Médias seguidas de mesma letra minúscula na coluna e maiúscula na linha, não diferem estatisticamente entre si, pelo teste de Tukey a $5 \%$ de probabilidade 
Zahabu et. al. (2015), obtiveram valores de 8,93; 8,70 e 8,47 MPa para cisalhamento paralelo às fibras em três diferentes espaçamentos, com 2 × 2; 3 × 3 e 4 × 4 metros, em floresta com 14 anos de idade na Tanzânia. Não houve diferença significativa entre os espaçamentos, mas nota-se que os valores obtidos são bastante inferiores aos apresentados por esse estudo.

Ribeiro et. al., 2010, encontraram uma boa correlação entre a densidade básica e a resistência ao cisalhamento de 18 espécies de madeiras tropicais da Amazônia, com valores variando de 5,95 até 17,16 MPa, o que indica que os valores dos testes de cisalhamento da madeira de teca nesse estudo apresentam boa resistência.

\subsubsection{Resistência à compressão paralela (RCO)}

Houve diferença significativa entre a resistência à compressão paralela apenas para a madeira coletada no plantio de 9,4 anos em Angatuba/SP, em comparação com os plantios do estado do Mato Grosso, em várias idades (tabela 19). É interessante notar que, mesmo com as diferenças de manejo adotados entre os plantios do MT, não houve diferença significativa entre as resistências à compressão paralela obtidas nas diferentes idades. Isso indica que o plantio de 9,5 anos, com população inicial menor do que os outros tratamentos, apresentou resultados similares, sem diferença significativa, com a madeira de florestas com idade mais avançada.

Tabela 19. Resistência a compressão paralela 12\% (RCO) das madeiras de teca coletadas na Fazenda Santa Maria no estado de São Paulo e nas Fazendas Mutum, Santa Maria do Jauru e Panflora no estado do Mato Grosso

\begin{tabular}{|c|c|c|c|c|c|}
\hline Fazenda & Município & $\begin{array}{l}\text { Idade } \\
\text { (anos) }\end{array}$ & Parâmetros & $\begin{array}{c}\text { No } \\
\text { dados }\end{array}$ & $\begin{array}{c}\text { Resistência à } \\
\text { compressão RCO } \\
12 \%(\mathrm{MPa})\end{array}$ \\
\hline \multirow{4}{*}{ Santa Maria } & \multirow{4}{*}{ Angatuba/SP } & \multirow{4}{*}{9,4} & Média & \multirow{4}{*}{60} & $34,04 \mathrm{~b}$ \\
\hline & & & C.V. & & 14,94 \\
\hline & & & V. mínimo & & 28,79 \\
\hline & & & V. máximo & & 41,43 \\
\hline \multirow{4}{*}{ Mutum } & \multirow{4}{*}{ Glória D’Oeste/MT } & \multirow{4}{*}{9,5} & Média & \multirow{4}{*}{60} & 41,71 a \\
\hline & & & C.V. & & 6,94 \\
\hline & & & V. mínimo & & 36,90 \\
\hline & & & V. máximo & & 44,12 \\
\hline \multirow{4}{*}{ Santa Maria do Jauru } & \multirow{4}{*}{ Porto Espiridião/MT } & \multirow{4}{*}{14,4} & Média & \multirow{4}{*}{60} & $38,54 a b$ \\
\hline & & & C.V. & & 4,59 \\
\hline & & & V. mínimo & & 37,32 \\
\hline & & & V. máximo & & 41,61 \\
\hline \multirow{4}{*}{ Panflora } & \multirow{4}{*}{ Rosário D’Oeste/MT } & \multirow{4}{*}{18,7} & Média & \multirow{4}{*}{60} & 41,98 a \\
\hline & & & C.V. & & 8,73 \\
\hline & & & V. mínimo & & 36,56 \\
\hline & & & V. máximo & & 46,26 \\
\hline \multicolumn{4}{|c|}{ MÉDIA GERAL } & \multirow{4}{*}{240} & 39,07 \\
\hline \multicolumn{4}{|c|}{ C.V. } & & 11,86 \\
\hline \multicolumn{4}{|c|}{ Valor mínimo } & & 28,79 \\
\hline & Valor máximo & & & & 46,26 \\
\hline
\end{tabular}

*Médias seguidas de mesma letra minúscula na coluna e maiúscula na linha, não diferem estatisticamente entre si, pelo teste de Tukey a $5 \%$ de probabilidade 
Zahabu et. al. (2015), encontraram valor médio de resistência a compressão paralela às fibras de 40,12 MPa, em plantios de teca com 14 anos na Tanzânia. Em plantio de 13 anos de idade plantado em Vazante, MG, Blanco Flórez (2012) encontrou uma resistência média à compressão paralela de 475 kgf cm², ou seja, 46,58 MPa.

Motta (2011) encontrou valores de $552 \mathrm{kgf} \mathrm{cm}^{-2}$, o que corresponde a 54,23 MPa para compressão paralela em plantios de 15 anos em Minas Gerais não desbastados.

Para Pinto (2007), existe uma tendência de aumento da resistência à compressão paralela das fibras ao longo da idade, sendo que os valores médios obtidos no MT foram de 39,14; 43,68 e 56,40 MPa respectivamente, para plantios de 5, 10 e 30 anos de idade.

Thulasidas \& Bhat (2012) encontraram valores de resistência a compressão paralela em teca de 35 anos de idade de 52 e $61 \mathrm{MPa}$, respectivamente para regiões de clima mais úmido e mais seco. Nesse caso, houve também correlação positiva e significativa entre a densidade básica e a compressão paralela. Também houve uma tendência de menores valores de resistência da direção radial da parte externa para o centro da madeira.

Em um plantio de teca com 50 a 70 anos de idade no Timor Leste, Miranda et. al. (2011), obtiveram resistência máxima à compressão paralela às fibras, medidas em três posições radiais da medula até a casca, variando de 45 a $52 \mathrm{MPa}$. Por outro lado, Josue \& Imiyabir (2011), estudando as características da madeira de teca em um plantio de 15 anos, encontraram valor médio de $39 \mathrm{MPa}$.

\subsubsection{Dureza da madeira}

A dureza, segundo Oliveira et. al. (2007), é a capacidade de o material resistir à abrasão superficial, fornecendo a ideia de resistência ao desgaste. É importante na escolha da madeira para usos estruturais que podem sofrer intervenções com ferramentas cortantes ou que necessitam ser furadas ou pregadas.

Motta (2011) encontrou valor médio de dureza de $491 \mathrm{kgf}$ em teca com 15 anos de idade, plantada em Belo Oriente, MG, região Metropolitana do Vale do Aço. Esse valor é, pelo menos, 25\% maior do que os valores obtidos nesse estudo (tabela 20).

Similar aos resultados de Motta (2011), também, Blanco Flórez (2012) encontrou valor médio para dureza de 475 kgf, em plantio de teca com 13 anos de idade em Vazante, MG, na região noroeste do estado.

CFC / ITTO (2009) obteve a dureza da madeira de teca em 4 idades, 14, 20, 25 e 30 anos. Aos 14 e 20 anos de idade a dureza foi calculada em 295,72 kgf, tendo aumentado para 336,51 kgf na idade de 25 anos e 265,13 kgf na idade de 30 anos. Portanto, parece não haver uma relação entre a idade e a dureza da madeira, como foi comprovado nesse estudo (tabela 22). 
Tabela 20. Dureza das madeiras de teca coletadas na Fazenda Santa Maria no estado de São Paulo e nas Fazendas Mutum, Santa Maria do Jauru e Panflora no estado do Mato Grosso

\begin{tabular}{|c|c|c|c|c|c|c|c|}
\hline \multirow{2}{*}{ Fazenda } & \multirow{2}{*}{ Município } & \multirow{2}{*}{$\begin{array}{l}\text { Idade } \\
\text { (anos) }\end{array}$} & \multirow{2}{*}{ Parâmetros } & \multirow{2}{*}{$\begin{array}{c}\mathrm{N}^{\circ} \\
\text { dados }\end{array}$} & \multicolumn{3}{|c|}{ Dureza 12\% (kgf) } \\
\hline & & & & & radial & tangencial & média \\
\hline \multirow{4}{*}{ Santa Maria } & \multirow{4}{*}{ Angatuba/SP } & \multirow{4}{*}{9,4} & Média & \multirow{4}{*}{50} & $317,05 \mathrm{c}$ & $329,97 \mathrm{~b}$ & 323,51 \\
\hline & & & C.V. & & 12,51 & 11,63 & 8,87 \\
\hline & & & V. Mínimo & & 275,65 & 293,16 & 284,41 \\
\hline & & & V. Máximo & & 360,99 & 375,88 & 363,33 \\
\hline \multirow{4}{*}{ Mutum } & \multirow{4}{*}{ Glória D’Oeste/MT } & \multirow{4}{*}{9,5} & Média & \multirow{4}{*}{50} & 400,44 a & $420,69 \mathrm{a}$ & 410,56 \\
\hline & & & C.V. & & 20,68 & 18,27 & 19,33 \\
\hline & & & V. Mínimo & & 318,95 & 349,64 & 334,29 \\
\hline & & & V. Máximo & & 505,31 & 526,50 & 515,90 \\
\hline \multirow{4}{*}{ Santa Maria do Jauru } & \multirow{4}{*}{ Porto Espiridião/MT } & \multirow{4}{*}{14,4} & Média & \multirow{4}{*}{50} & $346,60 \mathrm{bc}$ & $363,48 \mathrm{~b}$ & 355,04 \\
\hline & & & C.V. & & 16,26 & 15,22 & 15,58 \\
\hline & & & V. Mínimo & & 289,42 & 308,83 & 302,73 \\
\hline & & & V. Máximo & & 434,16 & 444,67 & 439,42 \\
\hline \multirow{4}{*}{ Panflora } & \multirow{4}{*}{ Rosário D’Oeste/MT } & \multirow{4}{*}{18,7} & Média & \multirow{4}{*}{50} & $355,97 \mathrm{~b}$ & $351,88 \mathrm{~b}$ & 353,92 \\
\hline & & & C.V. & & 7,05 & 6,93 & 6,81 \\
\hline & & & V. Mínimo & & 325,88 & 327,23 & 326,56 \\
\hline & & & V. Máximo & & 393,82 & 381,77 & 387,79 \\
\hline \multicolumn{4}{|c|}{ MÉDIA GERAL } & \multirow{4}{*}{200} & 355,02 & 366,50 & 360,76 \\
\hline \multicolumn{4}{|c|}{ C.V. } & & 16,71 & 16,16 & 15,93 \\
\hline \multicolumn{4}{|c|}{ Valor mínimo } & & 275,65 & 293,16 & 284,41 \\
\hline \multicolumn{4}{|c|}{ Valor máximo } & & 505,31 & 526,50 & 515,90 \\
\hline
\end{tabular}

*Médias seguidas de mesma letra na vertical, não diferem estatisticamente entre si, pelo teste de Tukey a $5 \%$ de probabilidade

Similar aos resultados de Motta (2011), também, Blanco Flórez (2012) encontrou valor médio para dureza de 475 kgf, em plantio de teca com 13 anos de idade em Vazante, MG, na região noroeste do estado.

CFC / ITTO (2009) obteve a dureza da madeira de teca em 4 idades, 14, 20, 25 e 30 anos. Aos 14 e 20 anos de idade a dureza foi calculada em 295,72 kgf, tendo aumentado para 336,51 kgf na idade de 25 anos e 265,13 kgf na idade de 30 anos. Portanto, parece não haver uma relação entre a idade e a dureza da madeira, como foi comprovado nesse estudo (tabela 22).

\subsubsection{Flexão Estática}

Segundo Polato et. al. (2005), a teca pode ser usada para propósitos estruturais em construções de casas, mas também, de barcos e navios. Polato et. al. (2005) avaliaram as propriedades mecânicas de plantios de teca no Brasil para verificar se as propriedades dessa madeira plantada têm os requerimentos de força necessários para esses usos finais. Esses autores sugeriram que, os resultados de MOR e MOE da flexão estática, confirmaram que as propriedades mecânico-elásticas mesmo com uma alta taxa de crescimento da floresta, não são inferiores para a madeira oriunda de teca de longa rotação ou de crescimento natural na sua área de origem. 
Tabela 21. Flexão estática 12\% (MOR - Módulo de ruptura e MOE - Módulo de elasticidade) das madeiras de teca coletadas na Fazenda Santa Maria no estado de São Paulo e nas Fazendas Mutum, Santa Maria do Jauru e Panflora no estado do Mato Grosso

\begin{tabular}{|c|c|c|c|c|c|c|}
\hline \multirow{2}{*}{ Fazenda } & \multirow{2}{*}{ Município } & \multirow{2}{*}{$\begin{array}{l}\text { Idade } \\
\text { (anos) }\end{array}$} & \multirow{2}{*}{ Parâmetros } & \multirow{2}{*}{$\begin{array}{c}\mathrm{No} \\
\text { dados }\end{array}$} & \multicolumn{2}{|c|}{ Flexão Estática $12 \%\left(\mathrm{kgf} \mathrm{cm}^{-2}\right)$} \\
\hline & & & & & MOR & MOE \\
\hline \multirow{4}{*}{ Santa Maria } & \multirow{4}{*}{ Angatuba/SP } & \multirow{4}{*}{9,4} & Média & \multirow{4}{*}{40} & $835,84 \mathrm{a}$ & $102.029,95$ a \\
\hline & & & C.V. & & 12,78 & 21,32 \\
\hline & & & V. Mínimo & & 703,68 & $84.761,59$ \\
\hline & & & V. Máximo & & 979,13 & $137.091,44$ \\
\hline \multirow{4}{*}{ Mutum } & \multirow{4}{*}{ Glória D’Oeste/MT } & \multirow{4}{*}{9,5} & Média & \multirow{4}{*}{40} & $989,21 \mathrm{a}$ & $111.818,22$ a \\
\hline & & & C.V. & & 12,17 & 15,35 \\
\hline & & & V. Mínimo & & 847,53 & $91.027,15$ \\
\hline & & & V. Máximo & & $1.142,39$ & $138.026,78$ \\
\hline \multirow{4}{*}{ Santa Maria do Jauru } & \multirow{4}{*}{ Porto Espiridião/MT } & \multirow{4}{*}{14,4} & Média & \multirow{4}{*}{40} & $916,27 \mathrm{a}$ & $102.330,07$ a \\
\hline & & & C.V. & & 7,16 & 11,27 \\
\hline & & & V. Mínimo & & 814,00 & $85.425,19$ \\
\hline & & & V. Máximo & & 993,61 & $114.710,88$ \\
\hline \multirow{4}{*}{ Panflora } & \multirow{4}{*}{ Rosário D’Oeste/MT } & \multirow{4}{*}{18,7} & Média & \multirow{4}{*}{40} & 987,43 a & $121.717,92$ a \\
\hline & & & C.V. & & 5,92 & 10,01 \\
\hline & & & V. Mínimo & & 913,61 & $104.469,84$ \\
\hline & & & V. Máximo & & $1.052,99$ & $131.800,24$ \\
\hline \multicolumn{4}{|c|}{ MÉDIA GERAL } & \multirow{4}{*}{160} & 932,19 & $107.224,04$ \\
\hline \multicolumn{4}{|c|}{ C.V. } & & 11,38 & 14,55 \\
\hline \multicolumn{4}{|c|}{ Valor Mínimo } & & 703,68 & $84.761,59$ \\
\hline \multicolumn{4}{|c|}{ Valor Máximo } & & $1.142,39$ & $138.026,78$ \\
\hline
\end{tabular}

*Médias seguidas de mesma letra minúscula na coluna e maiúscula na linha, não diferem estatisticamente entre si, pelo teste de Tukey a 5\% de probabilidade

Os valores encontrados por Polato et. al. (2005), ficaram entre 117 e $152 \mathrm{MPa}$ para o módulo de ruptura da flexão estática (MOR) e de 9.062 até 12.892 MPa para o módulo de elasticidade da flexão estática (MOE). Os resultados encontrados na tabela 21 mostram uma variação de 835 a 989 kgf cm², ou seja, 82 até 97 MPa para MOR e 10.006 até 11.936 MPa para MOE, na madeira de teca coletadas em fazendas no estado de São Paulo e Mato Grosso. Porém, o estudo daquele autor avaliou duas regiões, sendo uma delas com árvores de 14 anos e duas outras com materiais de 22 anos de idade.

Segundo Bhat (2003), enquanto a rigidez média da madeira (módulo de elasticidade) e o esforço de flexão (módulo de ruptura) na madeira juvenil são $85 \%$ e $82 \%$, respectivamente, do valor da madeira madura, a resistência longitudinal à compressão é semelhante. Isso confirma a tendência de menor valor de MOR e MOE em madeira estudada no estado de São Paulo com 9,4 anos de idade, em relação aos plantios do Mato Grosso. Entretanto, mesmo com menor idade em relação as outras áreas estudadas no Mato Grosso, a Fazenda Mutum apresentou maior MOR e MOE (tabela 21). Isso pode indicar que, mesmo nessa idade as árvores atingiram maturidade em função da região de crescimento e do manejo diferenciado aplicado à essa condição. Lembrando que essa fazenda teve espaçamento maior no plantio em relação a todas as outras áreas, influenciando esse comportamento. 


\subsubsection{Comparação dos resultados de propriedades mecânicas com outras espécies}

Andrade, 2015 avaliou as propriedades mecânicas de diversas espécies potenciais e comerciais usadas para produção de piso. Na tabela 22 os resultados, para algumas dessas espécies tropicais, são apresentados. Comparandose os valores de flexão estática (MOR e MOE), resistência a compressão paralela às fibras e dureza, nota-se que apenas o Tauari mostrou resultado similar àqueles obtidos para a teca, enquanto as outras espécies apresentaram maiores valores. Apenas para a resistência ao cisalhamento os resultados da teca são similares a todas as espécies florestais comparadas. Isso indica que a madeira de teca não apresenta, mesmo em idade de corte da floresta, os melhores resultados para propriedades mecânicas indicadas para produção de piso. Apesar de existirem algumas espécies, nesse caso o Tauari, usadas para essa finalidade, com resultados similares à madeira de teca estudada.

Tabela 22. Propriedades mecânicas de algumas espécies tropicais usadas para produção de piso

\begin{tabular}{|c|c|c|c|c|c|c|}
\hline \multirow{3}{*}{ Nome comum } & \multirow{3}{*}{ Nome científico } & \multicolumn{2}{|c|}{ Flexão Estática } & \multirow{2}{*}{$\begin{array}{c}\text { Compressão } \\
\text { paralela }\end{array}$} & \multirow{2}{*}{ Cisalhamento } & \multirow{2}{*}{ Dureza* } \\
\hline & & MOR & MOE & & & \\
\hline & & \multicolumn{4}{|c|}{$\operatorname{kgf} \mathrm{cm}^{-2}$} & kgf \\
\hline Teca (MT - média) & Tectona grandis & 964 & 111.955 & 415 & 160 & 373 \\
\hline Teca (SP) & Tectona grandis & 836 & 102.030 & 347 & 130 & 324 \\
\hline Amendoim & Pterogyne nitens & 1.109 & 124.511 & 540 & - & - \\
\hline Cumaru & Dipteryx odorata & 1.663 & 158.000 & 1.086 & 161 & 1.601 \\
\hline Guaiuvira & Cordia americana & - & 124.230 & - & 163 & - \\
\hline Ipê & Handroanthus serratifolius & 1.726 & 131.000 & 869 & 137 & 1.406 \\
\hline Jatobá & Hymenaea courbaril & 1.399 & 159.000 & 773 & 194 & 1.116 \\
\hline Tauari & Couratari oblongifolia & 847 & 111.000 & 455 & 106 & 469 \\
\hline
\end{tabular}

Fonte: Adaptado de Andrade (2015)

\subsection{Correlação de Pearson entre a densidade básica, as propriedades mecânicas e as dimensões anatômicas}

Na tabela 23 e figura 23 são apresentados os coeficientes de correlação de Pearson entre as propriedades mecânicas da madeira de teca e a densidade básica. Houve correlação positiva entre todos os parâmetros de resistência com a densidade básica. Isso é corroborado por diversos autores (RICHTER, et. al. 2005; CALIL JR. et. al., 1998, RIBEIRO, et. al., 2010, THULASIDAS \& BHAT, 2012). Não houve correlação entre a idade com as outras características. Isso é importante na utilização de madeira de plantios mais novos e de menor resistência. Entretanto, é importante salientar que esse estudo avaliou idades superiores a 9,5 anos.

Para Thulasidas \& Bhat, 2012, o cisalhamento tem correlação significativa e positiva com a compressão paralela. Por outro lado, a compressão paralela às fibras tem correlação significativa com a dureza e a flexão estática nos módulos ruptura e elasticidade. 
Tabela 23. Coeficientes de correlação de Pearson entre densidade básica e as propriedades mecânicas da madeira de teca

\begin{tabular}{|c|c|c|c|c|c|c|c|c|c|}
\hline \multicolumn{10}{|c|}{ Coeficiente de correlação de Pearson, $N=20$} \\
\hline & Idade & p bas & $f \mathrm{v0}$ tang & $f \mathrm{v} 0 \mathrm{rad}$ & $f \mathbf{c 0}$ & $f$ h radial & $f \mathrm{~h}$ tang & $\begin{array}{l}f \text { M90 } \\
\text { MOR }\end{array}$ & $\begin{array}{l}f \text { M90 } \\
\text { MOE }\end{array}$ \\
\hline Idade & 1,0000 & $\begin{array}{c}0,4395 \mathrm{~ns} \\
0,0525\end{array}$ & $\begin{array}{c}0,3465 \mathrm{~ns} \\
0,1345\end{array}$ & $\begin{array}{c}0,2590 \mathrm{~ns} \\
0,2703\end{array}$ & $\begin{array}{c}0,3504 \mathrm{~ns} \\
0,1299\end{array}$ & $\begin{array}{c}-0,0350 \mathrm{~ns} \\
0,8834\end{array}$ & $\begin{array}{c}-0,1665 \mathrm{~ns} \\
0,4829\end{array}$ & $\begin{array}{c}0,2722 \mathrm{~ns} \\
0,2457\end{array}$ & $\begin{array}{c}0,1136 \mathrm{~ns} \\
0,6335\end{array}$ \\
\hline $\begin{array}{c}\text { Densidade } \\
\text { básica }\end{array}$ & $\begin{array}{c}0,4395 \mathrm{~ns} \\
0,0525\end{array}$ & 1,0000 & $\begin{array}{c}0,6769 * * \\
0,001\end{array}$ & $\begin{array}{c}0,6728 * * \\
0,0012\end{array}$ & $\begin{array}{c}0,7472 * * \\
0,0002\end{array}$ & $\begin{array}{c}0,8701 * * \\
<0,001\end{array}$ & $\begin{array}{c}0,8894 * * \\
<0,01\end{array}$ & $\begin{array}{c}0,8639 * * \\
<0,01\end{array}$ & $\begin{array}{c}0,6635 \text { ** } \\
0,0014\end{array}$ \\
\hline $\begin{array}{c}\text { Cisalhamento } \\
\text { tangencial }\end{array}$ & $\begin{array}{c}0,3465 \mathrm{~ns} \\
0,1345\end{array}$ & $\begin{array}{c}0,6769 * * \\
0,001\end{array}$ & 1,0000 & $\begin{array}{c}0,9399 * * \\
<0,01\end{array}$ & $\begin{array}{c}0,6117 * * \\
0,0042\end{array}$ & $\begin{array}{c}0,2578 \mathrm{~ns} \\
0,2725\end{array}$ & $\begin{array}{c}0,2802 \mathrm{~ns} \\
0,2316\end{array}$ & $\begin{array}{c}0,2573 \mathrm{~ns} \\
0,2735\end{array}$ & $\begin{array}{c}0,0927 \mathrm{~ns} \\
0,6976\end{array}$ \\
\hline $\begin{array}{c}\text { Cisalhamento } \\
\text { radial }\end{array}$ & $\begin{array}{c}0,2590 \mathrm{~ns} \\
0,2703\end{array}$ & $\begin{array}{c}0,6723 * * \\
0,0012\end{array}$ & $\begin{array}{c}0,9399 * * \\
<0,01\end{array}$ & 1,0000 & $\begin{array}{c}0,5483 * \\
0,0123\end{array}$ & $\begin{array}{c}0,2089 \mathrm{~ns} \\
0,3968\end{array}$ & $\begin{array}{c}0,1848 \mathrm{~ns} \\
0,4355\end{array}$ & $\begin{array}{c}0,2510 \mathrm{~ns} \\
0,2857\end{array}$ & $\begin{array}{c}0,0803 \mathrm{~ns} \\
0,7364\end{array}$ \\
\hline $\begin{array}{c}\text { Compressão } \\
\text { paralela }\end{array}$ & $\begin{array}{c}0,3504 \mathrm{~ns} \\
0,1299\end{array}$ & $\begin{array}{c}0,7472 * * \\
0,0002\end{array}$ & $\begin{array}{c}0,6117 * * \\
0,0042\end{array}$ & $\begin{array}{c}0,5483 * \\
0,0123\end{array}$ & 1,0000 & $\begin{array}{c}0,3793 \mathrm{~ns} \\
0,0991\end{array}$ & $\begin{array}{c}0,4586 * \\
0,042\end{array}$ & $\begin{array}{c}0,6005 * * \\
0,0051\end{array}$ & $\begin{array}{c}0,4879 * \\
0,0291\end{array}$ \\
\hline $\begin{array}{c}\text { Dureza } \\
\text { radial }\end{array}$ & $\begin{array}{c}-0,0350 \mathrm{~ns} \\
0,8834\end{array}$ & $\begin{array}{c}0,8707 * * \\
<0,01\end{array}$ & $\begin{array}{c}0,2578 \mathrm{~ns} \\
0,2725\end{array}$ & $\begin{array}{c}0,2089 \mathrm{~ns} \\
0,3768\end{array}$ & $\begin{array}{c}0,3793 \mathrm{~ns} \\
0,0991\end{array}$ & 1,0000 & $\begin{array}{c}0,8814 * * \\
<0,01\end{array}$ & $\begin{array}{c}0,3162 \mathrm{~ns} \\
0,1745\end{array}$ & $\begin{array}{c}0,4343 \mathrm{~ns} \\
0,0557\end{array}$ \\
\hline $\begin{array}{c}\text { Dureza } \\
\text { tangencial }\end{array}$ & $\begin{array}{c}-0,1665 \mathrm{~ns} \\
0,4829\end{array}$ & $\begin{array}{c}0,8894 * * \\
<0,01\end{array}$ & $\begin{array}{c}0,2802 \mathrm{~ns} \\
0,2316\end{array}$ & $\begin{array}{c}0,1848 \mathrm{~ns} \\
0,4355\end{array}$ & $\begin{array}{c}0,4586 * \\
0,042\end{array}$ & $\begin{array}{c}0,8814 * * \\
<0,01\end{array}$ & 1,0000 & $\begin{array}{c}0,3288 \mathrm{~ns} \\
0,157\end{array}$ & $\begin{array}{c}0,4409 \mathrm{~ns} \\
0,0517\end{array}$ \\
\hline $\begin{array}{l}\text { MOR Flexão } \\
\text { estática }\end{array}$ & $\begin{array}{c}0,2722 \mathrm{~ns} \\
0,2457\end{array}$ & $\begin{array}{c}0,8639 * * \\
<0,01\end{array}$ & $\begin{array}{c}0,2573 \mathrm{~ns} \\
0,2735\end{array}$ & $\begin{array}{c}0,2510 \mathrm{~ns} \\
0,2857\end{array}$ & $\begin{array}{c}0,6005 * * \\
0,0051\end{array}$ & $\begin{array}{c}0,3162 \mathrm{~ns} \\
0,1745\end{array}$ & $\begin{array}{c}0,3288 \mathrm{~ns} \\
0,157\end{array}$ & 1,0000 & $\begin{array}{c}0,8007 * * \\
<0,01\end{array}$ \\
\hline $\begin{array}{c}\text { MOE Flexão } \\
\text { estática }\end{array}$ & $\begin{array}{c}0,1136 \mathrm{~ns} \\
0,6335\end{array}$ & $\begin{array}{c}0,6635 * * \\
0,0014\end{array}$ & $\begin{array}{c}0,0927 \mathrm{~ns} \\
0,6976\end{array}$ & $\begin{array}{c}0,0803 \mathrm{~ns} \\
0,7364\end{array}$ & $\begin{array}{c}0,4879 * \\
0,0291\end{array}$ & $\begin{array}{c}0,4343 \mathrm{~ns} \\
0,0557\end{array}$ & $\begin{array}{c}0,4409 \mathrm{~ns} \\
0,0517\end{array}$ & $\begin{array}{c}0,8008 * * \\
<0,01\end{array}$ & 1,0000 \\
\hline
\end{tabular}

* Há correlação a nível de 5\% de probabilidade. ** Há correlação a nível de 1\% de probabilidade. ns Não significativo 

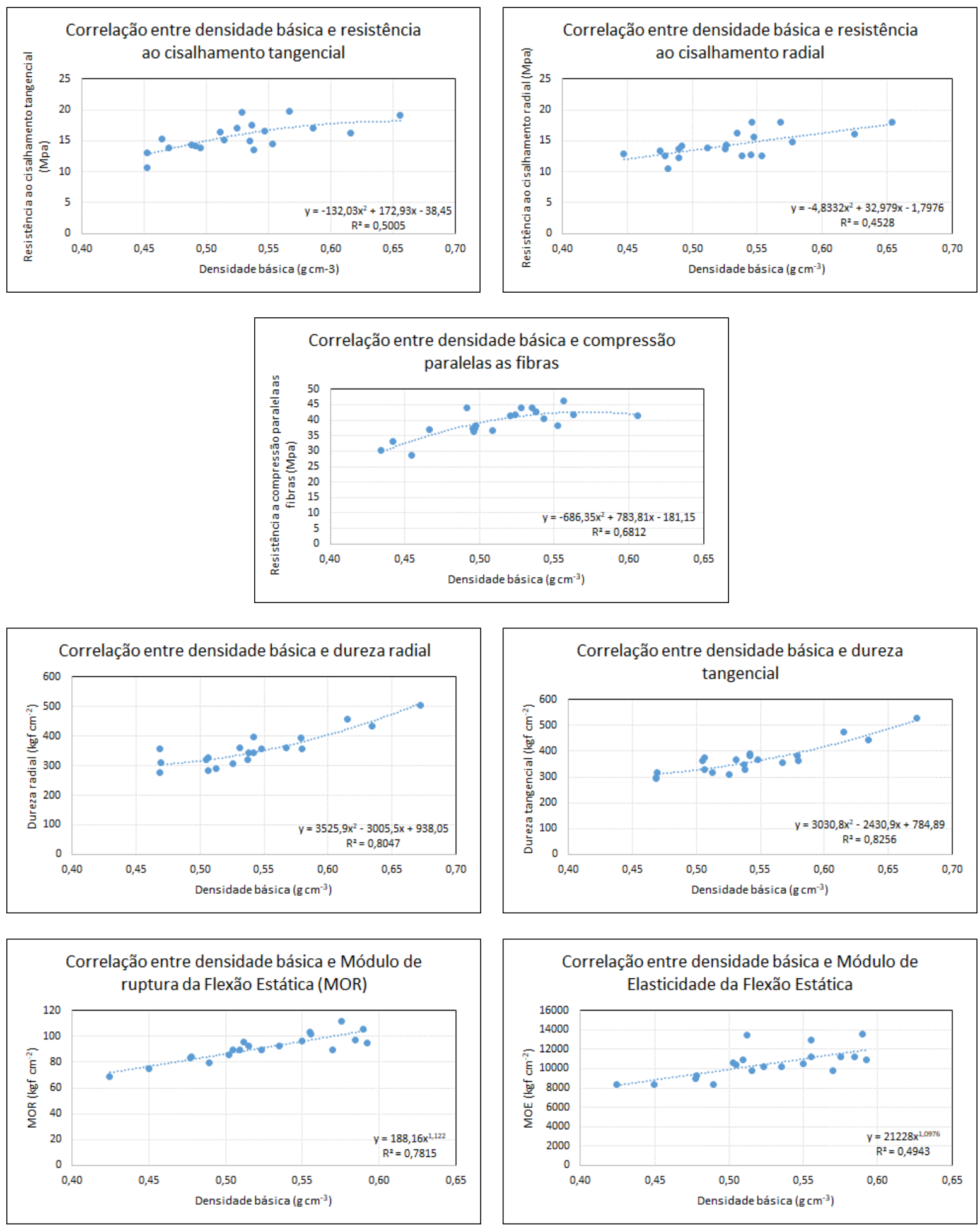

Figura 23. Correlação entre a densidade básica e as propriedades mecânicas da madeira de teca

Quanto as correlações entre as propriedades mecânicas e as dimensões anatômicas das fibras (tabela 24 e figura 24), os valores são positivos entre o comprimento de fibra e a compressão paralela $(0,5931$ **) e o Módulo de ruptura $(\mathrm{MOR})$ da Flexão Estática $(0,4870 *)$; o diâmetro da fibra relaciona-se com o cisalhamento radial $(0,4573$ *) e a espessura da parede correlaciona-se positivamente com o MOR e MOE da Flexão Estática, 0,5876 ** e 0,4610 *, respectivamente. Essas correlações entre as dimensões anatômicas e a densidade básica e as propriedades mecânicas 
são corroboradas por diversos autores (LIMA et. al., 2011; CANAL, 2017; CHAGAS et. al., 2014; RIBEIRO et. al., 2010; BLANCO FLÓREZ, 2012).

Tabela 24. Coeficientes de correlação de Pearson entre dimensões anatômicas das fibras e as propriedades mecânicas da madeira de teca

Coeficiente de correlação de Pearson, $\mathbf{N}=20$

\begin{tabular}{|c|c|c|c|c|c|c|c|c|c|c|}
\hline & $\begin{array}{c}\text { Comprimento } \\
\text { fibra }\end{array}$ & $\begin{array}{c}\text { Densidade } \\
\text { básica }\end{array}$ & $\begin{array}{c}\text { Diâmetro } \\
\text { fibra }\end{array}$ & $\begin{array}{c}\text { Espessura } \\
\text { parede }\end{array}$ & $f \mathrm{v} 0$ tang & $f \mathrm{v0} \mathrm{rad}$ & $f \mathrm{co}$ & $f \mathrm{~h} 90$ & $\begin{array}{l}\mathrm{fM90} \\
\text { MOR }\end{array}$ & $\begin{array}{l}f M 90 \\
\text { MOE }\end{array}$ \\
\hline $\begin{array}{c}\text { Comprimento } \\
\text { fibra }\end{array}$ & 1,0000 & $\begin{array}{c}0,6851 * * \\
0,0009\end{array}$ & $\begin{array}{c}0,2577 \mathrm{~ns} \\
0,2727\end{array}$ & $\begin{array}{c}0,4411 \mathrm{~ns} \\
0,0516\end{array}$ & $\begin{array}{c}0,4203 \mathrm{~ns} \\
0,065\end{array}$ & $\begin{array}{c}0,3256 \mathrm{~ns} \\
0,1613\end{array}$ & $\begin{array}{c}0,5931 * * \\
0,0058\end{array}$ & $\begin{array}{c}0,2290 \mathrm{~ns} \\
0,3315\end{array}$ & $\begin{array}{c}0,4870 * \\
0,0294\end{array}$ & $\begin{array}{c}0,3701 \mathrm{~ns} \\
0,1083\end{array}$ \\
\hline $\begin{array}{c}\text { Diâmetro } \\
\text { fibra }\end{array}$ & $\begin{array}{c}0,2577 \mathrm{~ns} \\
0,2727\end{array}$ & $\begin{array}{c}-0,1350 \mathrm{~ns} \\
0,5703\end{array}$ & 1,0000 & $\begin{array}{c}-0,1364 \mathrm{~ns} \\
0,5664\end{array}$ & $\begin{array}{c}0,3508 \mathrm{~ns} \\
0,1294\end{array}$ & $\begin{array}{c}0,4573 * \\
0,0426\end{array}$ & $\begin{array}{c}0,3794 \mathrm{~ns} \\
0,0990\end{array}$ & $\begin{array}{c}-0,2339 \mathrm{~ns} \\
0,3210\end{array}$ & $\begin{array}{c}0,1533 \mathrm{~ns} \\
0,5188\end{array}$ & $\begin{array}{c}0,0345 \mathrm{~ns} \\
0,8853\end{array}$ \\
\hline $\begin{array}{c}\text { Espessura } \\
\text { parede }\end{array}$ & $\begin{array}{c}0,4411 \mathrm{~ns} \\
0,0516\end{array}$ & $\begin{array}{c}0,7823 * * \\
<, 0001\end{array}$ & $\begin{array}{c}-0,1364 \mathrm{~ns} \\
0,5664\end{array}$ & 1,0000 & $\begin{array}{c}0,3371 \mathrm{~ns} \\
0,1461\end{array}$ & $\begin{array}{c}0,2408 \mathrm{~ns} \\
0,3065\end{array}$ & $\begin{array}{c}0,3608 \mathrm{~ns} \\
0,1181\end{array}$ & $\begin{array}{c}0,2656 \mathrm{~ns} \\
0,2577\end{array}$ & $\begin{array}{c}0,5876 \text { ** } \\
0,0064\end{array}$ & $\begin{array}{c}0,4610 * \\
0,0408\end{array}$ \\
\hline
\end{tabular}

* Há correlação a nível de 5\% de probabilidade. ** Há correlação a nível de 1\% de probabilidade. ns Não significativo
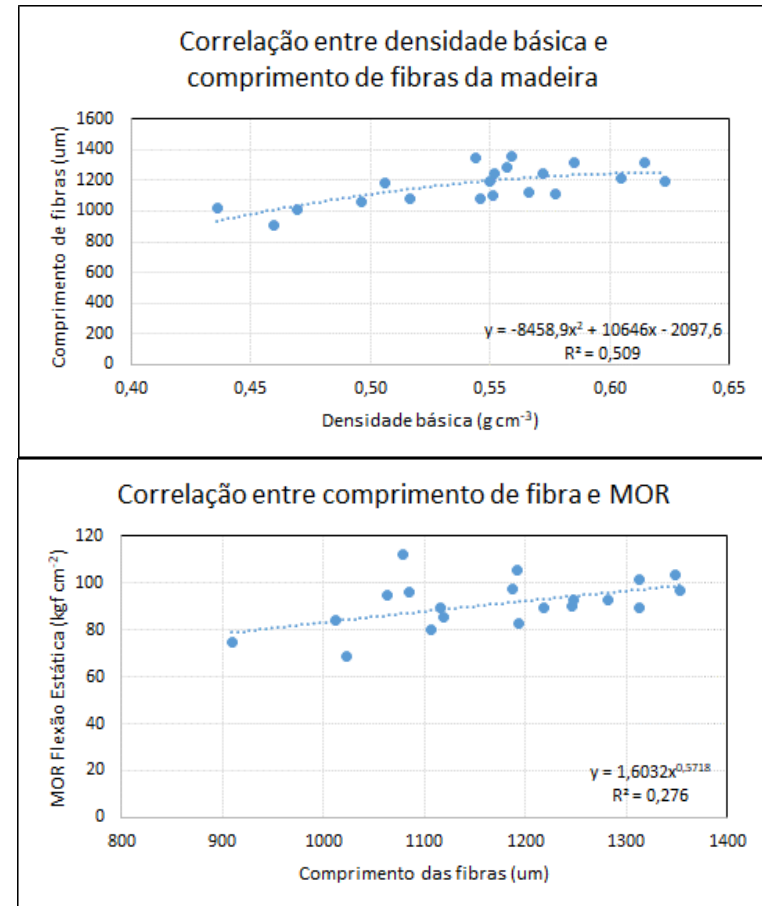

Correlação entre espessura da parede e MOR

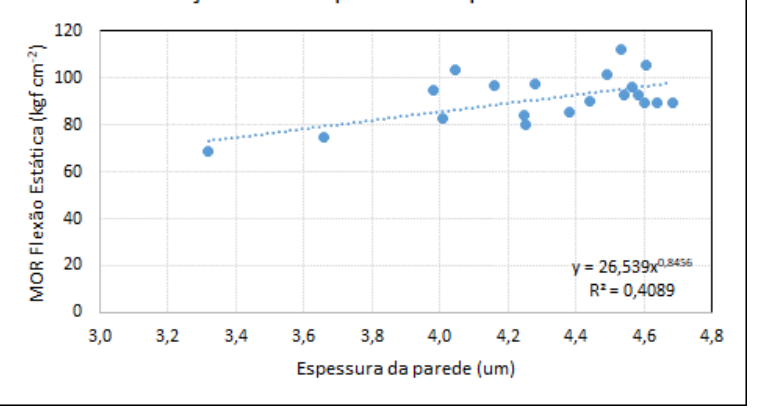

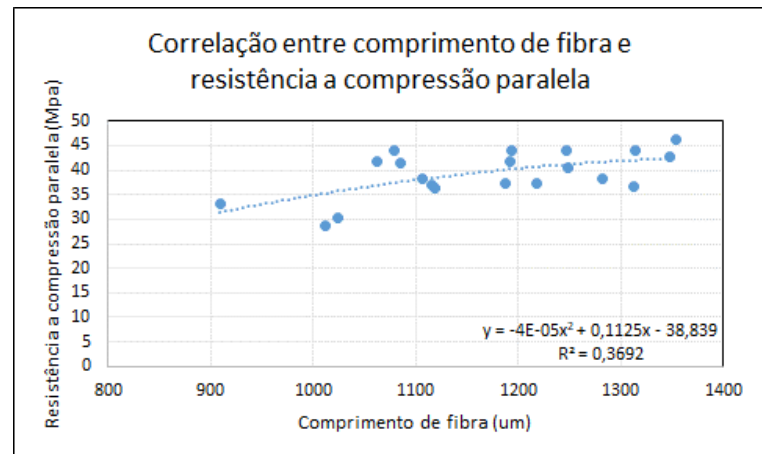

Correlação entre densidade básica e espessura da parede

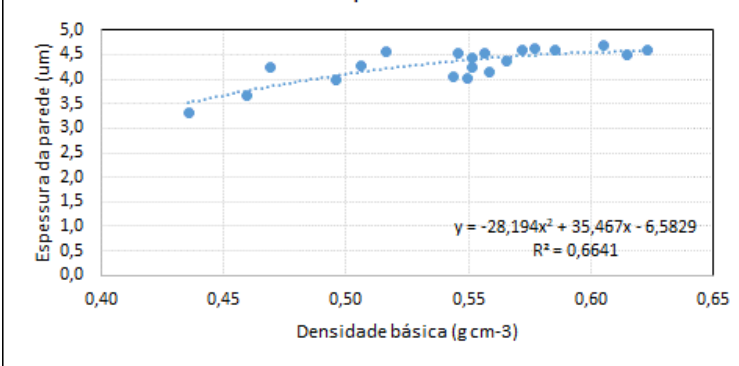

Correlação entre espessura da parede e MOE

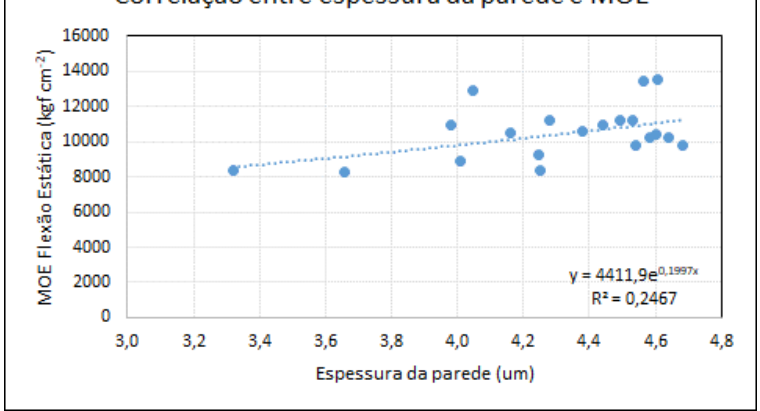

Figura 24. Correlação entre as dimensões anatômicas e as propriedades mecânicas da madeira de teca 


\subsection{Programas de secagem}

Os valores de umidade inicial (Ui) e a massa de água nas amostras verde, a 30\% e a 5\% são apresentados na tabela 25 .

Tabela 25. Valores da umidade inicial (Ui) e das massas de água total (M1), com 30\% de umidade (M30) e com 5\% de umidade (M5), para as amostras de teca do Mato Grosso em florestas de 3 idades (9,5; 14,4 e 18,7 anos) e em Angatuba com 9,4 anos de idade

\begin{tabular}{|c|c|c|c|c|c|c|}
\hline \multirow{2}{*}{ Fazenda } & \multirow{2}{*}{ Município } & \multirow{2}{*}{$\begin{array}{l}\text { Idade } \\
\text { (anos) }\end{array}$} & \multirow{2}{*}{$\begin{array}{c}\text { Umidade } \\
\text { inicial (Ui) } \\
(\%)\end{array}$} & \multicolumn{3}{|c|}{ Massa de água nas amostras (g) } \\
\hline & & & & M1 (verde) & M30 (U=30\%) & M5 (U=5\%) \\
\hline Santa Maria & Angatuba/SP & 9,4 & 146,25 & 36,28 & 8,33 & 2,26 \\
\hline Mutum & Glória D’Oeste/MT & 9,5 & 74,77 & 28,76 & 14,70 & 6,62 \\
\hline Santa Maria do Jauru & Porto Espiridião/MT & 14,4 & 84,44 & 31,70 & 14,42 & 6,16 \\
\hline Panflora & Rosário D’Oeste/MT & 18,7 & 90,26 & 31,08 & 12,16 & 4,22 \\
\hline
\end{tabular}

O teor inicial de umidade (Ui) das amostras de Angatuba/SP, submetidas à secagem drástica estava acima dos teores verificados nas amostras do MT. A provável explicação para essa diferença é o tempo que as amostras do MT permaneceram estocadas até que fosse realizada a secagem, apesar dos cuidados na embalagem das peças. Além disso, a menor proporção cerne/alburno também afetou essa umidade inicial.

Na tabela 27 são apresentados os valores de densidade básica, índice de rachadura interna e intensidade do colapso dos tratamentos. A menor densidade básica da madeira de Angatuba/SP segue os resultados da densidade obtida nas amostras de cunhas retiradas dos discos da base de cada árvore (tabela 12). Em termos de rachadura interna e índice de colapso não houve diferença entre os tratamentos.

Tabela 26. Valores de densidade básica e dos Índices de Rachaduras Internas e intensidade de colapso, para as amostras de teca do Mato Grosso em florestas de 3 idades (9,5; 14,4 e 18,7) e em Angatuba/SP com 9,4 anos de idade

\begin{tabular}{cccccc}
\hline Fazenda & Município & $\begin{array}{c}\text { Idade } \\
\mathbf{( a n o s )}\end{array}$ & $\begin{array}{c}\text { Densidade básica } \\
\left(\mathbf{g ~ c m}^{-3}\right)\end{array}$ & $\begin{array}{c}\text { Rachadura } \\
\text { interna (Ri) }\end{array}$ & $\begin{array}{c}\text { Índice de colapso } \\
(\mathbf{C C})\end{array}$ \\
\hline Santa Maria & Angatuba/SP & 9,4 & 0,4465 & 1,083 & 1,750 \\
\hline Mutum & Glória D'Oeste/MT & 9,5 & 0,5249 & 1,000 & 1,000 \\
\hline Santa Maria do Jauru & Porto Espiridião/MT & 14,4 & 0,5230 & 1,000 & 1,800 \\
\hline Panflora & Rosário D’Oeste/MT & 18,7 & 0,5426 & 2,240 \\
\hline
\end{tabular}

Na tabela 27 são apresentados os tempos e taxas de secagem, que apresentam certa similaridade entre os tratamentos. Os programas de secagem de cada tratamento são apresentados nos apêndices 1, 2, 3 e 4.

Tabela 27. Tempos de secagem (T1, T2 e T3) e taxas de secagem (V1, V2 e V3), para as amostras de teca do Mato Grosso em florestas de 3 idades (9,5; 14,4 e 18,7 anos) e em Angatuba/SP com 9,4 anos de idade

\begin{tabular}{|c|c|c|c|c|c|c|c|c|}
\hline \multirow[b]{2}{*}{ Fazenda } & \multirow[b]{2}{*}{ Município } & \multirow[b]{2}{*}{$\begin{array}{l}\text { Idade } \\
\text { (anos) }\end{array}$} & \multicolumn{3}{|c|}{ Tempo de secagem (h) } & \multicolumn{3}{|c|}{ Taxa de secagem $\left(\mathrm{g} \mathrm{cm}^{-2} \mathrm{~h}\right)$} \\
\hline & & & $\begin{array}{c}\text { T1 } \\
\text { (U a } 5 \%)\end{array}$ & $\begin{array}{c}\mathrm{T} 2 \\
\text { (U a } 30 \%)\end{array}$ & $\begin{array}{c}\text { T3 } \\
\text { (U } 30 \text { a } 5)\end{array}$ & $\begin{array}{c}\mathrm{V} 1 \\
(\mathrm{U} \text { a } 5 \%)\end{array}$ & $\begin{array}{c}\mathrm{V} 2 \\
(\mathrm{U} \text { a } 30 \%)\end{array}$ & $\begin{array}{c}\mathrm{V} 3 \\
\text { (U } 30 \text { a } 5)\end{array}$ \\
\hline Santa Maria & Angatuba/SP & 9,4 & 9,9732 & 4,793 & 5,180 & 0,0347 & 0,059 & 0,012 \\
\hline Mutum & Glória D’Oeste/MT & 9,5 & 8,6431 & 3,391 & 5,252 & 0,0310 & 0,057 & 0,014 \\
\hline Santa Maria do Jauru & Porto Espiridião/MT & 14,4 & 10,1047 & 3,995 & 6,110 & 0,0303 & 0,055 & 0,013 \\
\hline Panflora & Rosário D’Oeste/MT & 18,7 & 10,4491 & 4,093 & 6,356 & 0,0272 & 0,051 & 0,012 \\
\hline
\end{tabular}


Os valores de temperatura inicial e final e o potencial de secagem para os parâmetros dos programas de secagem são apresentados na tabela 28 e também são bastante similares entre os tratamentos.

Os resultados sugerem que o mesmo programa de secagem para a teca pode ser utilizado em diferentes idades e em plantios de várias regiões, indicando que não há variação significativa da estrutura da madeira no fator secagem.

Tabela 28. Valores usados para a montagem dos programas de secagem (Ti, Tf e PS), com base nos resultados do ensaio de secagem a $100^{\circ} \mathrm{C}$

\begin{tabular}{cccccc}
\hline \multirow{2}{*}{ Fazenda } & Município & Idade & \multicolumn{2}{c}{ Temperatura ( $\left.{ }^{\circ} \mathbf{C}\right)$} & \multicolumn{2}{c}{ Potencial de } \\
\cline { 5 - 6 } & & $($ anos $)$ & Inicial & Final & secagem \\
\hline Santa Maria & Angatuba/SP & 9,4 & 48,32 & 72,29 & 2,74 \\
\hline Mutum & Glória D’Oeste/MT & 9,5 & 46,99 & 70,82 & 2,61 \\
\hline Santa Maria do Jauru & Porto Espiridião/MT & 14,4 & 46,33 & 70,57 & 2,54 \\
\hline Panflora & Rosário D'Oeste/MT & 18,7 & 45,17 & 69,41 & 2,44 \\
\hline
\end{tabular}

\subsection{Produção e qualidade do piso produzido}

\subsubsection{Rendimento da produção de piso}

O rendimento para a produção de tábuas (tabela 29) apresentou valores crescentes em função da idade, mas com pequenas diferenças. Na produção dos pisos o rendimento seguiu a mesma tendência, apresentando valores crescentes com a idade das florestas. Isso já era esperado, em função do maior diâmetro médio das árvores em cada um dos tratamentos.

O volume de toras por árvore do tratamento de Angatuba representou apenas 33\% do volume individual da Fazenda Mutum. Porém, a população da Fazenda Santa Maria (Angatuba/SP) foi de praticamente o dobro da população da Fazenda Mutum, o que acarretou volume total de 95,43 $\mathrm{m}^{3} \mathrm{ha}^{-1}$ para Angatuba e 139,12 $\mathrm{m}^{3} \mathrm{ha}^{-1}$ para a Fazenda Mutum. Isso significa que a Fazenda Mutum apresentou maior produção por área em função do maior diâmetro médio das árvores, 14,81 cm para Angatuba e 21,39 cm para a Fazenda de Glória D’Oeste/MT, devido a menor população, ou seja, manejo diferenciado com o estabelecimento inicial do povoamento com espaçamento maior do que o que ocorreu na Fazenda Santa Maria.

É interessante notar que, apesar dos diâmetros médios dos tratamentos com 14,4 e 18,7 anos das florestas plantadas no Mato Grosso serem maiores do que os plantios com 9,4 anos (Angatuba/SP) e 9,5 anos (Glória D’Oeste/MT), a produção final de piso por área foi menor nesses tratamentos do que a da Fazenda Mutum. Como a população das Fazendas com 14,4 e 18,7 anos no Mato Grosso são ambas menores do que 200 árvores por hectare, a produção por área de piso é menor e, portanto, o ganho relativo nessas fazendas para a produção de piso é menor. Assim, nessas áreas com baixa população o melhor é exportar as toras diretamente para obter maior valor financeiro, em função do maior diâmetro das árvores. Portanto, é possível utilizar-se os desbastes para a produção de piso se houver um manejo adequado para se produzir árvores de diâmetro que gere maior rendimento na produção desse produto. No entanto, uma avaliação do custo de produção deve ser implementada para garantir esses resultados. 
Tabela 29. Rendimento volumétrico da produção de tábuas e pisos de Tectona grandis para as amostras de florestas do Mato Grosso e do estado de São Paulo

\begin{tabular}{|c|c|c|c|c|c|c|c|c|c|c|c|c|c|}
\hline \multirow{3}{*}{ Fazenda } & \multirow{3}{*}{ Município } & \multirow{3}{*}{$\begin{array}{l}\text { Idade } \\
\text { (anos) }\end{array}$} & \multirow{3}{*}{$\begin{array}{l}\text { População } \\
\text { (árv. ha' }^{-1} \text { ) }\end{array}$} & \multirow{3}{*}{ Árvore } & \multicolumn{9}{|c|}{ VOLUME } \\
\hline & & & & & \multicolumn{2}{|c|}{ Tora } & \multicolumn{2}{|c|}{ Tábua } & \multirow{2}{*}{$\begin{array}{c}\begin{array}{c}\text { Índice } \\
\text { conversão }\end{array} \\
\begin{array}{c}\text { Tora / Tábua } \\
(\%)\end{array}\end{array}$} & \multicolumn{2}{|c|}{ Piso } & \multicolumn{2}{|c|}{ Índice conversão } \\
\hline & & & & & $\begin{array}{l}\text { Individual } \\
\quad\left(\mathrm{cm}^{3}\right)\end{array}$ & $\begin{array}{l}\text { Por área } \\
\left(\mathrm{m}^{3} \mathrm{ha}^{-1}\right)\end{array}$ & $\begin{array}{l}\text { Individual } \\
\left(\mathrm{cm}^{3}\right)\end{array}$ & $\begin{array}{c}\text { Por área }\left(\mathrm{m}^{3}\right. \\
\left.\mathrm{ha}^{-1}\right)\end{array}$ & & $\begin{array}{l}\text { Individual } \\
\left(\mathrm{cm}^{3}\right)\end{array}$ & $\begin{array}{l}\text { Por área } \\
\left(\mathrm{m}^{3} \mathrm{ha}^{-1}\right)\end{array}$ & $\begin{array}{c}\text { Tábua / Piso } \\
\text { (\%) }\end{array}$ & $\begin{array}{c}\text { Tora / Piso } \\
\text { (\%) }\end{array}$ \\
\hline \multirow{6}{*}{ Santa Maria } & \multirow{6}{*}{ Angatuba/SP } & \multirow{6}{*}{9,4} & \multirow{6}{*}{950} & 1 & $86.860,76$ & 82,52 & $35.031,54$ & 33,28 & 40,33 & $15.916,11$ & 15,12 & 45,43 & 18,32 \\
\hline & & & & 2 & $101.608,02$ & 96,53 & $37.313,16$ & 35,45 & 36,72 & $17.112,54$ & 16,26 & 45,86 & 16,84 \\
\hline & & & & 3 & $109.154,66$ & 103,7 & $42.862,14$ & 40,72 & 39,27 & $21.301,09$ & 20,24 & 49,70 & 19,51 \\
\hline & & & & 4 & $100.211,45$ & 95,2 & $31.804,57$ & 30,21 & 31,74 & $16.574,46$ & 15,75 & 52,11 & 16,54 \\
\hline & & & & 5 & $104.415,21$ & 99,19 & $40.122,48$ & 38,12 & 38,43 & $20.898,96$ & 19,85 & 52,09 & 20,02 \\
\hline & & & & MÉDIA & $100.450,02 \mathrm{~d}$ & $95,43 \mathrm{~b}$ & $37.426,78 \mathrm{~d}$ & $35,56 \mathrm{~b}$ & 37,30 & $18.360,63 \mathrm{~d}$ & $17,44 \mathrm{~b}$ & 49,04 & 18,25 \\
\hline \multirow{6}{*}{ Mutum } & \multirow{6}{*}{ Glória D’Oeste/MT } & \multirow{6}{*}{9,5} & \multirow{6}{*}{458} & 1 & $325.380,98$ & 149,02 & $118.806,44$ & 54,41 & 36,51 & $64.980,76$ & 29,76 & 54,69 & 19,97 \\
\hline & & & & 2 & $317.151,05$ & 145,26 & $127.359,96$ & 58,33 & 40,16 & $72.388,10$ & 33,15 & 56,84 & 22,82 \\
\hline & & & & 3 & $309.762,50$ & 141,87 & $128.297,40$ & 58,76 & 41,42 & $65.331,69$ & 29,92 & 50,92 & 21,09 \\
\hline & & & & 4 & $285.882,55$ & 130,93 & $106.586,49$ & 48,82 & 37,28 & $52.607,39$ & 24,09 & 49,36 & 18,40 \\
\hline & & & & 5 & $280.591,36$ & 128,51 & $106.312,01$ & 48,69 & 37,89 & $53.333,95$ & 24,43 & 50,17 & 19,01 \\
\hline & & & & MÉDIA & $303.753,69 \mathrm{c}$ & $139,12 \mathrm{a}$ & $117.472,46 \mathrm{c}$ & 53,80 a & 38,65 & $61.728,38 \mathrm{c}$ & $28,27 \mathrm{a}$ & 52,40 & 20,26 \\
\hline \multirow{6}{*}{$\begin{array}{l}\text { Santa Maria do } \\
\text { Jauru }\end{array}$} & \multirow{6}{*}{ Porto Espiridião/MT } & \multirow{6}{*}{14,4} & \multirow{6}{*}{195} & 1 & $469.937,03$ & 91,64 & $236.896,19$ & 46,19 & 50,41 & $135.032,05$ & 26,33 & 57,00 & 28,73 \\
\hline & & & & 2 & $601.543,60$ & 117,3 & $227.342,27$ & 44,33 & 37,79 & $117.256,03$ & 22,86 & 51,58 & 19,49 \\
\hline & & & & 3 & $594.132,71$ & 115,86 & $244.844,23$ & 47,74 & 41,21 & $135.822,64$ & 26,49 & 55,47 & 22,86 \\
\hline & & & & 4 & $613.848,71$ & 119,7 & $233.989,36$ & 45,63 & 38,12 & $121.282,13$ & 23,65 & 51,83 & 19,76 \\
\hline & & & & 5 & $604.420,38$ & 117,86 & $234.387,85$ & 45,71 & 38,78 & $126.269,44$ & 24,62 & 53,87 & 20,89 \\
\hline & & & & MÉDIA & $576.776,48 \mathrm{~b}$ & $112,47 \mathrm{~b}$ & $235.491,98 \mathrm{~b}$ & $45,92 \mathrm{a}$ & 41,26 & $127.132,46 \mathrm{~b}$ & $24,79 \mathrm{a}$ & 53,95 & 22,35 \\
\hline \multirow{6}{*}{ Panflora } & \multirow{6}{*}{ Rosário D’Oeste/MT } & \multirow{6}{*}{18,7} & \multirow{6}{*}{135} & 5 & $884.453,18$ & 119,4 & $308.377,44$ & 41,63 & 34,87 & $163.764,80$ & 22,11 & 53,11 & 18,52 \\
\hline & & & & 6 & $801.182,88$ & 108,16 & $353.623,57$ & 47,74 & 44,14 & $205.762,40$ & 27,78 & 58,19 & 25,68 \\
\hline & & & & 7 & $948.599,03$ & 128,06 & $305.728,83$ & 41,27 & 32,23 & $162.582,62$ & 21,95 & 53,18 & 17,14 \\
\hline & & & & 9 & $775.217,93$ & 104,65 & $428.209,84$ & 57,81 & 55,24 & $245.766,71$ & 33,18 & 57,39 & 31,70 \\
\hline & & & & 10 & $711.121,21$ & 96,00 & $340.934,03$ & 46,03 & 47,94 & $186.339,84$ & 25,16 & 54,66 & 26,20 \\
\hline & & & & MÉDIA & $824.114,84 \mathrm{a}$ & $111,26 \mathrm{~b}$ & $347.374,74 \mathrm{a}$ & $46,90 \mathrm{a}$ & 42,88 & $192.843,27 \mathrm{a}$ & $26,03 \mathrm{a}$ & 55,30 & 23,85 \\
\hline
\end{tabular}

*Médias seguidas de mesma letra na vertical, não diferem estatisticamente entre si, pelo teste de Tukey a $5 \%$ de probabilidade 
O índice de conversão de toras para tábua foi de 37, 39, 41 e 43\% (tabela 29), respectivamente para as toras obtidas na fazenda com teca de 9,4 anos em SP; para a Fazenda Mutum do MT com 9,5 anos; Fazenda Santa Maria do Jauru com 14,4 anos e da Fazenda Panflora com plantio florestal de teca de 18,7 anos. Houve uma tendência de menor conversão nas fazendas mais novas, o que indica que para cada um dos tratamentos seriam necessários 2,70; 2,56; 2,44 e 2,33 $\mathrm{m}^{3}$ de tora para a produção de 1,00 $\mathrm{m}^{3}$ de tábua. Da mesma forma, a conversão de tábua para piso foi de 0,49; 0,52; 0,54 e 0,55, respectivamente para as toras obtidas na fazenda de SP; e as do MT com 9,4; 14,4 e 18,7 anos. Portanto, para a produção de $1 \mathrm{~m}^{3}$ de piso seriam necessários $5,52 \mathrm{~m}^{3}$ de tora ou 2,04 $\mathrm{m}^{3}$ de tábua para a Fazenda Santa Maria do plantio de SP; 4,93 $\mathrm{m}^{3}$ de tora ou 1,92 $\mathrm{m}^{3}$ de tábua para a Fazenda Mutum do MT, com 9,5 anos; 4,52 $\mathrm{m}^{3}$ de tora ou 1,85 $\mathrm{m}^{3}$ de tábua para a Fazenda Santa Maria do Jauru do MT, com 14,4 anos e 4,23 $\mathrm{m}^{3}$ de tora ou 1,82 $\mathrm{m}^{3}$ de tábua para a Fazenda Panflora do MT, com 18,7 anos.

Avaliando-se a correlação entre o volume médio de toras comerciais por árvore de teca e o rendimento do piso acabado individual (figura 25), nota-se que houve um comportamento bastante linear em relação aos tratamentos. Isso permite determinar volumes potenciais de produção de piso maciço, em função das dimensões das toras e da densidade populacional de plantios.

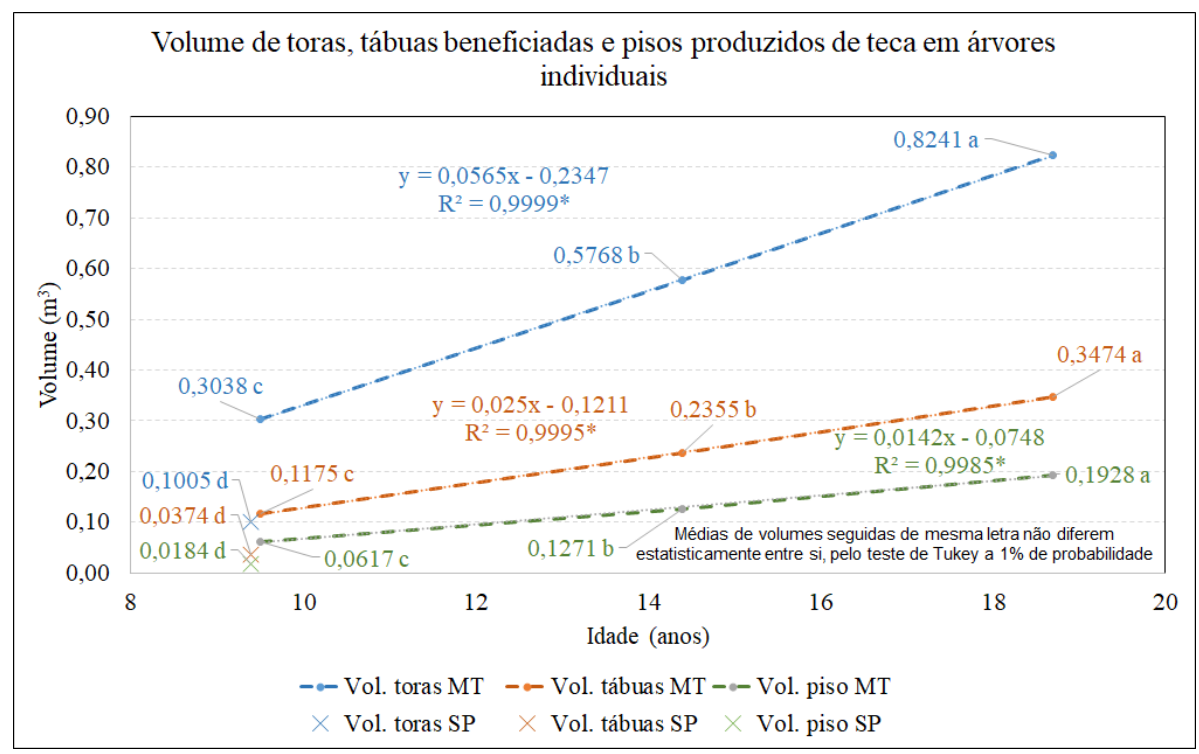

Figura 25. Rendimento de toras, tábuas beneficiadas e pisos produzidos das amostras de madeira das florestas com 3 idade no Mato Grosso (9,5; 14,4 e 18,7 anos) e em Angatuba/SP com 9,4 anos de idade

Apesar da maior produção por árvore de pisos nos tratamentos com maior idade, a produção total, baseada na densidade populacional atual dos plantios, é de $918 \mathrm{~m}^{2}$ para a Fazenda de Angatuba/SP, com 9,4 anos de idade e 950 árvores remanescentes por hectare; $1.488 \mathrm{~m}^{2}$ por hectare para a Fazenda Mutum (MT) com 9,5 anos de idade e 458 árvores remanescentes por hectare; $1.305 \mathrm{~m}^{2}$ por hectare no plantio com 14,4 anos do MT e 195 árvores remanescentes por hectare e $1.370 \mathrm{~m}^{2}$ por hectare na Fazenda Panflora, com 18,7 anos de idade e 135 árvores remanescentes por hectare. Isso, talvez indique que florestas de menor idade, mas bem manejadas, permitiriam o uso da madeira de desbaste para fins mais nobres, como a produção de piso. Para isso, sugere-se um cálculo de produção de pisos a partir do volume das árvores em idades de desbaste, avaliando-se o potencial econômico desse uso. 


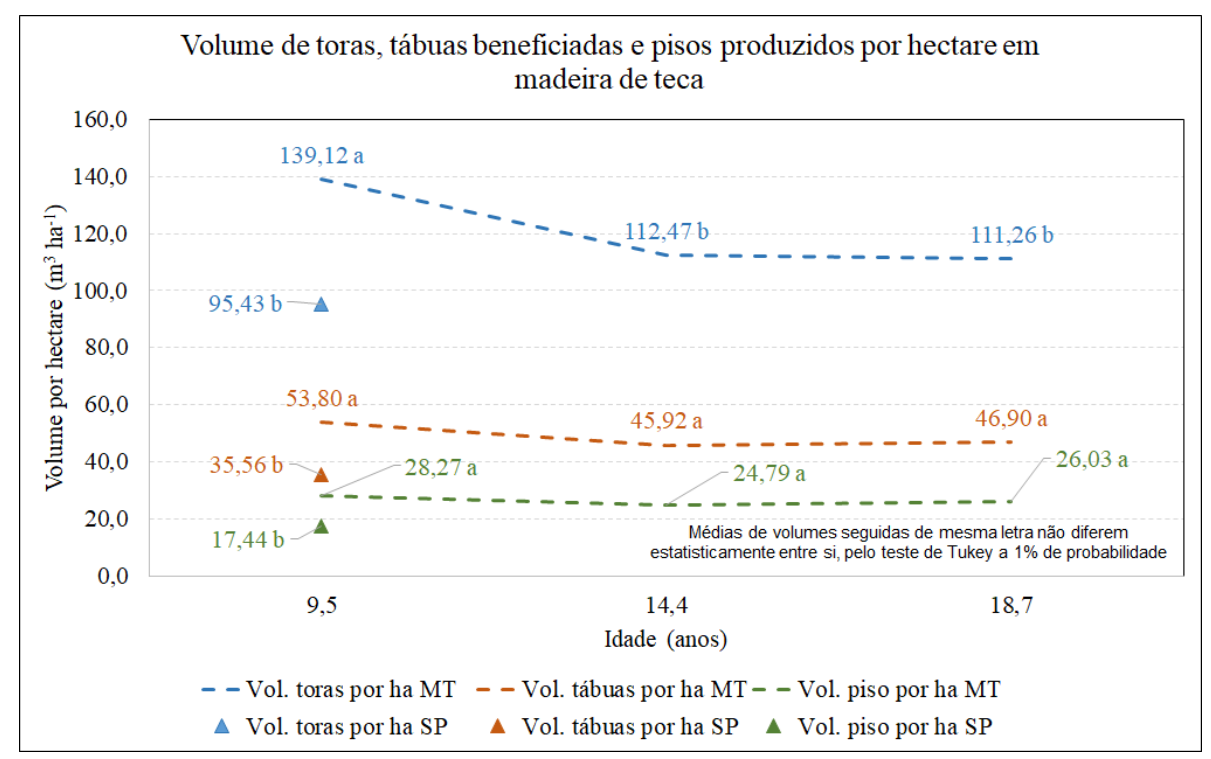

Figura 26. Rendimento de toras, tábuas beneficiadas e pisos produzidos por hectare das amostras de madeira das florestas com 3 idade no Mato Grosso (9,5; 14,4 e 18,7 anos) e em Angatuba/SP com 9,4 anos de idade

Tabela 30. Rendimento da produção de tábuas e pisos de Tectona grandis para as amostras de florestas com 3 idades no Mato Grosso (9,5; 14,41 e 18,7 anos) e em Angatuba/SP com 9,4 anos de idade

\begin{tabular}{|c|c|c|c|c|c|c|c|c|c|c|}
\hline \multirow{3}{*}{ Fazenda } & \multirow{3}{*}{ Município } & \multirow{3}{*}{$\begin{array}{r}\text { Idade } \\
\text { (anos) }\end{array}$} & \multirow{3}{*}{$\begin{array}{c}\text { População } \\
\left(\text { árv ha' }{ }^{-1}\right)\end{array}$} & \multirow{3}{*}{ Árvore } & \multicolumn{6}{|c|}{ ÁREA } \\
\hline & & & & & & Tábua & & & Piso & \\
\hline & & & & & $\left(\mathbf{c m}^{2}\right)$ & $\%$ & $\left(\mathrm{~m}^{2} \mathbf{h a}^{-1}\right)$ & $\left(\mathrm{cm}^{2}\right)$ & $\%$ & $\left(\mathrm{~m}^{2} \mathbf{h a}^{-1}\right)$ \\
\hline \multirow{6}{*}{ Santa Maria } & \multirow{6}{*}{ Angatuba/SP } & \multirow{6}{*}{9,4} & \multirow{6}{*}{950} & 1 & $14.657,55$ & 100,00 & $1.392,47$ & $\begin{array}{l}8.376,90 \\
\end{array}$ & 57,15 & 795,81 \\
\hline & & & & 2 & $15.612,20$ & 100,00 & $1.483,16$ & $9.006,60$ & 57,69 & 855,63 \\
\hline & & & & 3 & $17.933,95$ & 100,00 & $1.703,73$ & $11.211,10$ & 62,51 & $1.065,05$ \\
\hline & & & & 4 & $13.307,35$ & 100,00 & $1.264,20$ & $8.723,40$ & 65,55 & 828,72 \\
\hline & & & & 5 & $16.787,65$ & 100,00 & $1.594,83$ & $10.999,45$ & 65,52 & $1.044,95$ \\
\hline & & & & MÉDIA & $15.659,74 d$ & 100,00 & $1.487,68 \mathrm{~b}$ & $9.663,49$ & 61,69 & $918,03 b$ \\
\hline \multirow{6}{*}{ Mutum } & \multirow{6}{*}{ Glória D’Oeste/MT } & \multirow{6}{*}{9,5} & \multirow{6}{*}{458} & 1 & $47.145,60$ & 100,00 & $2.159,27$ & $34.200,40$ & 72,54 & $1.566,38$ \\
\hline & & & & 2 & $50.654,10$ & 100,00 & $2.319,96$ & $38.099,00$ & 75,21 & $1.744,93$ \\
\hline & & & & 3 & $50.830,50$ & 100,00 & $2.328,04$ & $34.385,10$ & 67,65 & $1.574,84$ \\
\hline & & & & 4 & $42.013,10$ & 100,00 & $1.924,20$ & $27.688,10$ & 65,90 & $1.268,11$ \\
\hline & & & & 5 & $42.009,30$ & 100,00 & $1.924,03$ & $28.070,50$ & 66,82 & $1.285,63$ \\
\hline & & & & MÉDIA & $46.530,52 \mathrm{c}$ & 100,00 & $2.131,10 \mathrm{a}$ & $32.488,62$ & 69,63 & $1.487,98 \mathrm{a}$ \\
\hline \multirow{6}{*}{$\begin{array}{c}\text { Santa Maria } \\
\text { do Jauru }\end{array}$} & \multirow{6}{*}{ Porto Espiridião/MT } & \multirow{6}{*}{14,4} & \multirow{6}{*}{195} & 1 & $92.319,40$ & 100,00 & $1.800,23$ & $71.069,50$ & 76,98 & $1.385,86$ \\
\hline & & & & 2 & $88.538,20$ & 100,00 & $1.726,49$ & $61.713,70$ & 69,70 & $1.203,42$ \\
\hline & & & & 3 & $96.275,30$ & 100,00 & $1.877,37$ & $71.485,60$ & 74,25 & $1.393,97$ \\
\hline & & & & 4 & $91.192,30$ & 100,00 & $1.778,25$ & $63.832,70$ & 70,00 & $1.244,74$ \\
\hline & & & & 5 & $91.895,00$ & 100,00 & $1.791,95$ & $66.457,60$ & 72,32 & $1.295,92$ \\
\hline & & & & MÉDIA & $92.044,04 b$ & 100,00 & $1.794,86 a b$ & $66.911,82$ & 72,65 & $1.304,78 \mathrm{a}$ \\
\hline \multirow{6}{*}{ Panflora } & \multirow{6}{*}{ Rosário D’Oeste/MT } & \multirow{6}{*}{18,7} & \multirow{6}{*}{135} & 5 & $119.677,10$ & 100,00 & $1.615,64$ & $86.192,00$ & 72,02 & $1.163,59$ \\
\hline & & & & 6 & $137.052,20$ & 100,00 & $1.850,20$ & $108.296,00$ & 79,02 & $1.462,00$ \\
\hline & & & & 7 & $119.466,50$ & 100,00 & $1.612,80$ & $85.569,80$ & 71,63 & $1.155,19$ \\
\hline & & & & 9 & $167.353,60$ & 100,00 & $2.259,27$ & $129.350,90$ & 77,29 & $1.746,24$ \\
\hline & & & & 10 & $133.283,80$ & 100,00 & $1.799,33$ & $98.073,60$ & 73,58 & $1.323,99$ \\
\hline & & & & MÉDIA & $135.366,64 a$ & $\overline{100,00}$ & $1.827,45 a b$ & $\overline{101.496,46}$ & 74,71 & $1.370,20 \mathrm{a}$ \\
\hline
\end{tabular}




\subsubsection{Qualidade do piso pronto}

A qualidade da madeira pode ser caracterizada por diversas propriedades, dependendo da importância delas no uso final do produto. Logicamente, a dureza é uma característica muito importante para determinar a qualidade do piso maciço de madeira. Por outro lado, a retratibilidade pode ser atualmente uma propriedade fundamental, em função do seu uso e possibilidade de deslocamento do piso com a umidade. Para a exportação essa característica é muito importante por causa da umidade de equilíbrio de determinadas regiões que podem variar e ocasionar problemas na instalação do piso. Nos ensaios realizados nos pisos foram verificados o brilho, a dureza pelo impacto de bola e a rugosidade.

Tabela 31. Brilho (UB) para as amostras de teca do Mato Grosso em florestas de 3 idades (9,5; 14,4 e 18,7 anos) e em Angatuba/SP com 9,4 anos de idade

\begin{tabular}{|c|c|c|c|c|c|c|c|}
\hline \multirow[b]{2}{*}{ Fazenda } & \multirow[b]{2}{*}{ Município } & \multirow[b]{2}{*}{$\begin{array}{l}\text { Idade } \\
\text { (anos) }\end{array}$} & \multirow[b]{2}{*}{ Parâmetros } & \multirow[b]{2}{*}{$\begin{array}{l}\mathrm{N}^{\circ} \text { de } \\
\text { dados }\end{array}$} & \multicolumn{3}{|c|}{ Unidade de brilho (UB) } \\
\hline & & & & & $\begin{array}{c}\text { Posição } \\
\text { transversal }\end{array}$ & $\begin{array}{c}\text { Posição } \\
\text { longitudinal }\end{array}$ & Média \\
\hline \multirow{4}{*}{ Santa Maria } & \multirow{4}{*}{ Angatuba/SP } & \multirow{4}{*}{9,4} & Média & \multirow{4}{*}{35} & $31,54 \mathrm{a}$ & $42,38 \mathrm{a}$ & 36,96 \\
\hline & & & C.V. & & 2,92 & 2,15 & 2,27 \\
\hline & & & V. Mínimo & & 30,20 & 41,71 & 35,96 \\
\hline & & & V. Máximo & & 32,65 & 43,83 & 38,24 \\
\hline \multirow{4}{*}{ Mutum } & \multirow{4}{*}{$\begin{array}{c}\text { Glória } \\
\text { D’Oeste/MT }\end{array}$} & \multirow{4}{*}{9,5} & Média & \multirow{4}{*}{35} & 31,96 a & $42,51 \mathrm{a}$ & 37,24 \\
\hline & & & C.V. & & 3,30 & 3,59 & 3,43 \\
\hline & & & V. Mínimo & & 30,49 & 40,80 & 35,64 \\
\hline & & & V. Máximo & & 33,11 & 44,69 & 38,90 \\
\hline \multirow{4}{*}{$\begin{array}{c}\text { Santa Maria do } \\
\text { Jauru }\end{array}$} & \multirow{4}{*}{$\begin{array}{c}\text { Porto } \\
\text { Espiridião/MT }\end{array}$} & \multirow{4}{*}{14,4} & Média & \multirow{4}{*}{35} & $32,09 \mathrm{a}$ & $42,60 \mathrm{a}$ & 37,34 \\
\hline & & & C.V. & & 1,38 & 0,96 & 1,10 \\
\hline & & & V. Mínimo & & 31,60 & 41,99 & 36,80 \\
\hline & & & V. Máximo & & 32,65 & 43,13 & 37,89 \\
\hline \multirow{4}{*}{ Panflora } & \multirow{4}{*}{$\begin{array}{c}\text { Rosário } \\
\text { D’Oeste/MT }\end{array}$} & \multirow{4}{*}{18,7} & Média & \multirow{4}{*}{35} & $31,68 \mathrm{a}$ & $42,17 \mathrm{a}$ & 36,92 \\
\hline & & & C.V. & & 0,99 & 1,55 & 1,27 \\
\hline & & & V. Mínimo & & 31,33 & 41,46 & 36,42 \\
\hline & & & V. Máximo & & 32,06 & 42,92 & 37,43 \\
\hline \multicolumn{4}{|c|}{ MÉDIA GERAL } & \multirow{4}{*}{140} & $31,82 \mathrm{~B}$ & $42,41 \mathrm{~A}$ & 37,12 \\
\hline \multicolumn{4}{|c|}{ C.V. } & & 2,28 & 2,13 & 2,10 \\
\hline \multicolumn{4}{|c|}{ Valor Mínimo } & & 30,20 & 40,80 & 35,64 \\
\hline \multicolumn{4}{|c|}{ Valor Máximo } & & 33,11 & 44,69 & 38,90 \\
\hline
\end{tabular}

*Médias seguidas de mesma letra minúscula na coluna e maiúscula na linha, não diferem estatisticamente entre si, pelo teste de Tukey a $\%$ de probabilidade

Os valores de brilho, resistência ao impacto e rugosidade são apresentados nas tabelas 31, 32 e 33, respectivamente. Não houve diferença entre nenhum dos parâmetros analisados, o que indica que a madeira é bastante homogênea entre as idades e regiões estudadas. Além disso, o verniz pode determinar uma maior resistência da madeira 
ao impacto. Isso denota um fator positivo sobre a possibilidade de uso de madeiras obtidas de florestas de teca mais jovens para produção de piso.

Andrade (2015) analisou diversas espécies florestais brasileiras quanto à qualidade do piso. A resistência ao impacto de bola teve média de 0,247 $\mathrm{mm}$ de profundidade, com menor valor obtido de 0,118 $\mathrm{mm}$ para o Angelimvermelho (Dinizia excelsa) e um máximo de 0,564 mm para o Cedrinho (Erisma uncinatum). Os resultados para rugosidade encontrados por esse autor variaram de um mínimo de $0,50 \mu \mathrm{m}$ no Cedrinho (Erisma uncinatum) para um máximo de 1,01 $\mu \mathrm{m}$ para a Castanha-sapucaia (Lecythis pisonis). Já o valor mínimo para brilho foi de 35,4 UB para a Maparajuba (Manilkara bidentata) e o valor máximo de 42,4 UB para o Tachi preto (Tachigali myrmecophila).

Tabela 32. Dureza (impacto de bola) para as amostras de teca do Mato Grosso em florestas de 3 idades (9,5; 14,4 e 18,7 anos) e em Angatuba/SP com 9,4 anos de idade

\begin{tabular}{|c|c|c|c|c|c|c|}
\hline \multirow[b]{2}{*}{ Fazenda } & \multirow[b]{2}{*}{ Município } & \multirow{2}{*}{$\begin{array}{l}\text { Idade } \\
\text { (anos) }\end{array}$} & \multirow[b]{2}{*}{ Parâmetros } & \multirow{2}{*}{$\begin{array}{l}\text { No de } \\
\text { dados }\end{array}$} & \multicolumn{2}{|c|}{ Dureza (impacto de bola) } \\
\hline & & & & & $\begin{array}{l}\text { Profundidade } \\
\qquad(\mathrm{mm})\end{array}$ & Classe \\
\hline \multirow{4}{*}{ Santa Maria } & \multirow{4}{*}{ Angatuba/SP } & \multirow{4}{*}{9,4} & Média & \multirow{4}{*}{70} & 0,402 a & $2,37 \mathrm{a}$ \\
\hline & & & C.V. & & 15,34 & 8,36 \\
\hline & & & V. Mínimo & & 0,348 & 2,14 \\
\hline & & & V. Máximo & & 0,502 & 2,57 \\
\hline \multirow{4}{*}{ Mutum } & \multirow{4}{*}{$\begin{array}{l}\text { Glória } \\
\text { D’Oeste/MT }\end{array}$} & \multirow{4}{*}{9,5} & Média & \multirow{4}{*}{70} & 0,395 a & $2,52 \mathrm{a}$ \\
\hline & & & C.V. & & 15,63 & 15,59 \\
\hline & & & V. Mínimo & & 0,349 & 2,00 \\
\hline & & & V. Máximo & & 0,501 & 2,86 \\
\hline \multirow{4}{*}{ Santa Maria do Jauru } & \multirow{4}{*}{$\begin{array}{c}\text { Porto } \\
\text { Espiridião/MT }\end{array}$} & \multirow{4}{*}{14,4} & Média & \multirow{4}{*}{70} & $0,394 \mathrm{a}$ & $2,42 \mathrm{a}$ \\
\hline & & & C.V. & & 11,78 & 6,75 \\
\hline & & & V. Mínimo & & 0,318 & 2,21 \\
\hline & & & V. Máximo & & 0,438 & 2,56 \\
\hline \multirow{4}{*}{ Panflora } & \multirow{4}{*}{$\begin{array}{c}\text { Rosário } \\
\text { D’Oeste/MT }\end{array}$} & \multirow{4}{*}{18,7} & Média & \multirow{4}{*}{70} & 0,373 a & $2,46 \mathrm{a}$ \\
\hline & & & C.V. & & 10,09 & 6,03 \\
\hline & & & V. Mínimo & & 0,325 & 2,21 \\
\hline & & & V. Máximo & & 0,408 & 2,57 \\
\hline \multicolumn{4}{|c|}{ MÉDIA GERAL } & \multirow{4}{*}{280} & $0,391 \mathrm{a}$ & $2,44 \mathrm{a}$ \\
\hline \multicolumn{4}{|c|}{ C.V. } & & 12,72 & 9,53 \\
\hline \multicolumn{4}{|c|}{ Valor Mínimo } & & 0,318 & 2,00 \\
\hline \multicolumn{4}{|c|}{ Valor Máximo } & & 0,502 & 2,86 \\
\hline
\end{tabular}

*Médias seguidas de mesma letra minúscula na coluna e maiúscula na linha, não diferem estatisticamente entre si, pelo teste de Tukey a 5\% de probabilidade

Comparando-se esses valores com os encontrados nesse estudo, os resultados para brilho e rugosidade são bastante similares aos encontrados na literatura, mas a madeira de teca, mesmo em idades mais velhas, é menos resistente que as espécies nativas estudadas por Andrade (2015), comparando os valores de resistência ao impacto.

É interessante notar que há diferença entre o brilho e a rugosidade avaliados no sentido longitudinal para o transversal da peça de piso. Isso pode estar correlacionado com a posição das fibras e outros elementos anatômicos na madeira, devido ao plano do piso estar no sentido longitudinal das toras, ou seja, na posição paralela as fibras. 
Tabela 33. Rugosidade para as amostras de teca do Mato Grosso em florestas de 3 idades (9,5; 14,4 e 18,7 anos) e em Angatuba/SP com 9,4 anos de idade

\begin{tabular}{|c|c|c|c|c|c|c|c|}
\hline \multirow[t]{2}{*}{ Fazenda } & \multirow[t]{2}{*}{ Município } & \multirow{2}{*}{$\begin{array}{l}\text { Idade } \\
\text { (anos) }\end{array}$} & \multirow[t]{2}{*}{ Parâmetros } & \multirow{2}{*}{$\begin{array}{l}\text { No de } \\
\text { dados }\end{array}$} & \multicolumn{3}{|c|}{$\begin{array}{c}\text { Rugosidade }(\mu \mathrm{m}) \\
\text { Posição }\end{array}$} \\
\hline & & & & & Longitudinal & Transversal & Média \\
\hline \multirow{4}{*}{ Santa Maria } & \multirow{4}{*}{ Angatuba/SP } & \multirow{4}{*}{9,4} & Média & \multirow{4}{*}{70} & $0,824 \mathrm{a}$ & $1,190 \mathrm{a}$ & $1,007 \mathrm{a}$ \\
\hline & & & C.V. & & 4,21 & 6,51 & 5,18 \\
\hline & & & V. Mínimo & & 0,780 & 1,094 & 0,937 \\
\hline & & & V. Máximo & & 0,874 & 1,298 & 1,065 \\
\hline \multirow{4}{*}{ Mutum } & \multirow{4}{*}{$\begin{array}{c}\text { Glória } \\
\text { D’Oeste/MT }\end{array}$} & \multirow{4}{*}{9,5} & Média & \multirow{4}{*}{70} & 0,866 a & $1,161 \mathrm{a}$ & $1,014 \mathrm{a}$ \\
\hline & & & C.V. & & 7,31 & 6,81 & 6,92 \\
\hline & & & V. Mínimo & & 0,826 & 1,076 & 0,953 \\
\hline & & & V. Máximo & & 0,978 & 1,291 & 1,135 \\
\hline \multirow{4}{*}{$\begin{array}{c}\text { Santa Maria do } \\
\text { Jauru }\end{array}$} & \multirow{4}{*}{$\begin{array}{l}\text { Porto } \\
\text { Espiridião/MT }\end{array}$} & \multirow{4}{*}{14,4} & Média & \multirow{4}{*}{70} & 0,884 a & $1,155 \mathrm{a}$ & $1,019 \mathrm{a}$ \\
\hline & & & C.V. & & 3,11 & 2,15 & 1,89 \\
\hline & & & V. Mínimo & & 0,857 & 1,124 & 0,992 \\
\hline & & & V. Máximo & & 0,922 & 1,180 & 1,044 \\
\hline \multirow{4}{*}{ Panflora } & \multirow{4}{*}{$\begin{array}{c}\text { Rosário } \\
\text { D’Oeste/MT }\end{array}$} & \multirow{4}{*}{18,7} & Média & \multirow{4}{*}{70} & 0,840 a & $1,191 \mathrm{a}$ & $1,015 \mathrm{a}$ \\
\hline & & & C.V. & & 4,20 & 2,34 & 2,83 \\
\hline & & & V. Mínimo & & 0,790 & 1,155 & 0,972 \\
\hline & & & V. Máximo & & 0,872 & 1,222 & 1,047 \\
\hline \multicolumn{4}{|c|}{ MÉDIA GERAL } & 280 & $0,854 \mathrm{a}$ & $1,174 \mathrm{a}$ & $\overline{1,014 \mathrm{a}}$ \\
\hline \multicolumn{4}{|c|}{ C.V. } & & 5,36 & 4,79 & 4,28 \\
\hline \multicolumn{4}{|c|}{ Valor Mínimo } & & 0,780 & 1,076 & 0,937 \\
\hline \multicolumn{4}{|c|}{ Valor Máximo } & & 0,978 & 1,298 & 1,135 \\
\hline
\end{tabular}

*Médias seguidas de mesma letra minúscula na coluna e maiúscula na linha, não diferem estatisticamente entre si, pelo teste de Tukey a $5 \%$ de probabilidade 


\section{CONCLUSÕES}

Entre os povoamentos do MT as árvores de teca apresentaram maior diâmetro médio em idades superiores. Dessa forma, o volume individual de madeira por árvore teve uma correlação linear com a idade, da qual obteve-se a seguinte equação: Volume individual $=0,0566$ x Idade $-0,2353$, com r $^{2}=0,9998 * *$. Por outro lado, o plantio de teca de SP apresentou crescimento dendrométrico muito menor do que o plantio com a mesma idade no MT, sendo $1 / 3$ do volume por árvore desse outro plantio. O plantio de SP tinha o dobro da densidade populacional. Além disso, os plantios apresentaram crescimento inicial diferente, avaliando-se os anéis de crescimento, em função das épocas de implantação, sendo que, as áreas plantadas no verão apresentaram maior arranque inicial.

A porcentagem de cerne foi maior em áreas com idades mais velhas, tendo havido correlação positiva entre o diâmetro das árvores e o volume de cerne obtido. A idade, em que o cerne atinge 50\% do volume comercial da árvore, foi alcançada aproximadamente aos 15 anos. A excentricidade da medula apresentou tendência de menores valores, conforme a idade, a partir do fortalecimento das árvores mais velhas.

Não houve correlação entre a densidade básica da madeira e as idades, mas o plantio de SP apresentou valor de densidade menor. Essa redução está relacionada também ao menor povoamento inicial. De outra maneira, a estabilidade dimensional foi menor no plantio de SP, apresentando maiores valores de retratibilidade e anisotropia na madeira do que nos tratamentos do MT.

Em termos das dimensões das fibras, o comprimento apresentou diferenças significativas entre as idades, sendo maior quanto mais velho o plantio. Entre o cerne e o alburno houve diferenças para o comprimento das fibras (maior no alburno), o diâmetro das fibras (maior no alburno) e a espessura da parede (maior no cerne).

Os teores de extrativos tiveram uma correlação positiva com a idade, que também, está relacionada à maior porcentagem de cerne. Isso concede maior durabilidade em plantios mais velhos, mas bem manejados.

Entre as propriedades mecânicas estudadas a resistência ao cisalhamento e a compressão paralela às fibras tiveram comportamento similar, com menores valores apenas encontrados no povoamento de SP, o que pode também se relacionar ao manejo e/ou clima dessa região. O maior valor médio de dureza Janka encontrado foi no plantio mais novo do MT. Para a flexão estática, tanto ruptura (MOR) quanto elasticidade (MOE), não houve diferença significativa entre as idades.

Houve correlação positiva entre todas as propriedades mecânicas e a densidade básica, mas não com a idade. O comprimento das fibras e a espessura das paredes das fibras também tiveram correlação direta com a densidade básica e com algumas propriedades mecânicas, como compressão paralela às fibras, MOR e MOE.

Ainda, foi possível identificar maior índice de conversão no processo de produção de piso quanto maior a idade da floresta e o diâmetro médio das árvores, sendo de 18,27; 20,32; 22,04 e 23,40\%, respectivamente para o plantio de São Paulo com 9,4 anos; e os do Mato Grosso, com 9,5; 14,4 e 18,7 anos. Entretanto, o volume de piso gerado por área foi maior no tratamento com 9,5 anos plantado no estado do Mato Grosso, em função do melhor manejo adotado, ou seja, menor densidade populacional inicial. Entre os ensaios de qualidade do piso, o brilho, a rugosidade e a resistência ao impacto apresentaram resultados sem diferenças significativas entre todas as idades.

Os resultados parecem indicar que não há diferenças significativas entre as principais propriedades da madeira e a idade, sendo que um manejo adequado da floresta é importante para se obter uma melhor qualidade da madeira. Mesmo assim, o produto final obtido em todos os tratamentos apresentou bons rendimentos de produção e boa qualidade final. 
Por outro lado, todas as propriedades mecânicas da madeira de teca estudadas apresentaram valores inferiores a maioria das espécies tropicais usadas comercialmente para produção de piso. Esse pode ser um fator limitante para uso de madeira de teca de desbaste para essa finalidade.

O desenho formado pela madeira de teca e sua cor também podem ser fatores limitantes para a produção de piso, em função do mercado. Entretanto, as possibilidades de tingimento do produto final ou, ainda, seu uso como base de piso engenheirado, podem viabilizar economicamente essa madeira de desbaste para finalidades mais nobres. Para isso, uma avaliação econômica mais abrangente, incluindo os custos industriais devem ser desenvolvidos.

Dentre os tratamentos avaliados o plantio com 9,5 anos do MT apresentou melhor produtividade de piso por área, o que mostra que esse tratamento, associado a essa finalidade, é mais vantajoso economicamente do que os outros, mas é necessária uma avaliação dos custos de produção do piso e de outros parâmetros de qualidade não determinados nesse estudo. Ainda assim, isso denota que o manejo aplicado nessa área, principalmente quanto a menor densidade populacional na implantação da floresta, apresentou melhores resultados de produção de toras e conversão para piso e boa qualidade do produto final. 


\section{REFERÊNCIAS}

ABNT Associação Brasileira de Normas Técnicas (1984) NBR 8404: Indicação do estado de superfícies em desenhos técnicos, 10 p., 1984

ABNT Associação Brasileira de Normas Técnicas (2000) NBR 14535: Móveis de madeira - Tratamentos de superfície - Requisitos de Proteção e acabamento, 22 p., 2000

ABNT Associação Brasileira de Normas Técnicas (2004). NBR 14660: Madeira - Amostragem e preparação para análise. Rio de Janeiro. 2004, 13p

Altschul SF, Madden TL, Schaffer AA, Zhang J, Zhang Z, Miller W, Lipman DJ (1997) Gapped BLAST and PSIBLAST: a new generation of protein database search programs. Nucleic Acids Res 25:3389-3402

Amaral, ACB, Tomazello Filho, M (1998) Avaliação das características dos anéis de crescimento de Pinus taeda pela microdensitometria de raios X. Revista Ciência e Tecnologia, Piracicaba, v. 6, n. 11, p. 17-23

Andrade, A, (2015) Pisos de madeira: características de espécies brasileiras, Piracicaba, ANPM, 2015, 184 p.

Arce, VH (2001) Relación albura duramen y características físicas de la madera de teca (Tectona grandis) en plantaciones de 10 años con dos diferentes densidades de plantación en playa garza Guanacaste Costa Rica. 2001. 36 f. Tesis (Pregrado en Ingenieria Forestal) - Universidad Nacional, Heredia

Arce, VH \& Moya, R (2015) Wood characterization of adult clones of Tectona grandis growing in Costa Rica, Cerne, v. 21 n. 3, p. 353-362, 2015

Arias, LU (2003), Quality concerns of sustainable teak wood chain, In: Bhat, KM, Nair, KKN, Bhat, KV, Muralidharan, EM \& Sharma JK Quality Timber Products of Teak from Sustainable Forest Management, Kerala Forest Research Institute, International Tropical Timber Organization, p. 92-103

ASTM - American Society for Testing and Materials (2011) Standard test methods for simulated service testing of wood and wood-base finish flooring. D 2394-05. Philadelphia, 2011

ASTM - American Society for Testing and Materials (2000) Standard test methods for small clear specimens of timber.

D 143-94. Philadelphia, 2000

Ball, JB, Pandey, D \& Hirai, S (1999) Global Overview of Teak Plantations Regional Seminar Site, Technology and Productivity of Teak Plantations Chiang Mai, Thailand 26-29, January 1999, 14 pág.

Barrichello, LEG (1983) Densidade básica: subsídios para determinação (1ª parte). Piracicaba: ESALQ, Departamento de Silvicultura, 1983. 6 p. (Informações SQCE, 3)

Batista, DC, Klitzke, RJ, Taborda Santos, CV (2010) Densidade básica e retratibilidade de madeira de clones de três espécies de Eucalyptus, Ciência Florestal, Santa Maria, v. 20, n. 4, p. 665-674, out.-dez., 2010

Bhat, KM (2003) Quality concerns of sustainable teak wood chain, In: Bhat, KM, Nair, KKN, Bhat, KV, Muralidharan, EM \& Sharma JK Quality Timber Products of Teak from Sustainable Forest Management, Kerala Forest Research Institute, International Tropical Timber Organization, p. 228-235

Blanco Flórez, J (2012) Caracterização tecnológica da madeira jovem de teca (Tectona grandis L. f.) / Jeimy Blanco Flórez. - Lavras: UFLA, 2012, Dissertação (Mestrado em Ciência e Tecnologia da Madeira) - Universidade de Lavras, Lavras, 2012, $85 \mathrm{p}$

Bonduelle, GM; Iwakiri, R; Trianoski, R, Prata, JG \& Yurk da Rocha, V (2015) Análise da massa específica da retratibilidade da madeira de Tectona grandis nos sentidos axial e radial do tronco, Floresta, Curitiba, PR, v. 45, n. 4, p. 671 - 680, out. / Dez. 2015. 
Boschetti, WTN; Paes, JB; Vidaurre, GB; Arantes MDC \& Palha Leite, F (2015). Parâmetros dendrométricos e excentricidade da medula em árvores inclinadas de eucalipto. Scientia Forestalis. 43. 10.18671/scifor.v43n108.4.

Burger, LM \& Richter, HG (1991) Anatomia da madeira, São Paulo, Nobel, 1991, 154 pág.

BSI - British Standard Institution (1957) BS 373: Methods of testing small clear specimens of timber. London, 1957

Cáceres Florestal, (2006) Manual do Cultivo da Teca, Cáceres Florestal, versão eletrônica atualizada em janeiro de 2006.

CFC/ITTO. (2009) Handbook on Properties of Plantation Teak in Myanmar. Study on Utilization of Plantation Teak Pre-project CFC/ITTO 73 FT PPD 68/03 Rev.2 (I).

Calil Jr, C; Baraldi, LT; Stamato, GC \& Ferreira, NSS (1998) Estruturas de madeira - Universidade de São Paulo Escola de Engenharia de São Carlos, São Carlos, Outubro de 1998, 107 p.

Canal, WD (2017) Efeito da idade e da posição radial nas propriedades anatômicas, físicas e químicas da madeira de Tectona grandis / Wagner Davel Canal - Viçosa, MG: Universidade Federal de Viçosa, 2017, Dissertação (Mestrado em Ciência Florestal) - Viçosa, 55 p

Camino, R \& Morales, JP (2013) Las plantaciones de teca em America Latina: Mitos y realidades, Centro Agronómico Tropical de Investigación y Enseñanza (CATIE), División de Investigación y Desarrollo, Série Técnica, Informe Técnico no 397, 392 pág.

Chagas, SF; Evangelista, WV; Silva, JC; Carvalho, AMML (2014) Propriedades da madeira de teca de diferentes idades e oriundas de desbaste. Ciência da Madeira (Brazilian Journal of Wood Science) 5(2): 138-150, 2014 DOI: 10.12953/2177-6830.v05n02a08

Chaix, G; Monteuuis, O; Goh, DKS; Bailleres, H \& Boutahar, N (2007) Quality Control and Mass Production of Teak Clones for Tropical Plantations In: Processing and Marketing of Teak Wood Products of Planted Forests, Proceedings of the Regional Workshop, Kerala Forest Research Institute, Peechi, India, 25-28 September 2007, págs. $146-157$

Climate-data.org (2018) https://pt.climate-data.org/

Colenci, AR (2002) Qualificação mecânica de madeiras para uso como dormente ferroviário. 2002. 90 p. Dissertação (Mestrado em Agronomia/Energia na Agricultura) - Faculdade de Ciências Agronômicas, Universidade Estadual Paulista, Botucatu, 2002.

COPANT - Commission Panamericana de Normas Técnicas (1974) Descripcion de características generales, macroscópicas de las maderas angiospermas dicotiledoneas. v.30. p.1-19. 1974

Cruz, JP, Leite, HG, Soares, CPB \& Campos, JCC (2008) Modelos de crescimento e produção para plantios comerciais jovens de Tectona grandis em Tangará da Serra, Mato Grosso, R. Árvore, Viçosa-MG, v.32, n.5, p.821-828, 2008.

Eleotério, JR \& Kirchheim da Silva, CM (2012) Comparação de programas de secagem para Cumaru (Dipteryx odorata), Jatobá (Hymenaea spp) e Muiracatiara (Astronium lecointę) obtidos por diferentes métodos, Scientia Forestalis, Piracicaba, v. 40, n. 96, p. 537-545, dez. 2012

Finger, Z; Finger, FA; Drescher, R (2001) - Fatores geográficos, geológicos, edáficos e climáticos limitantes da distribuição natural da teca (Tectona grandis L. f.). 1o Simpósio Brasileiro de pós-graduação em Engenharia Florestal, 2001, Santa Maria. Anais do $1^{\circ}$ simpósio brasileiro de pós-graduação em Engenharia Florestal. Santa Maria: Universidade Federal de Santa Maria. v. 1, p. 154-169

Finger, FA; Finger, Z; Logsdon, NB (2003) Qualificação da madeira de teca, Tectona grandis L. f., oriunda do primeiro desbaste comercial, com vistas a seu aproveitamento. Madeira: arquitetura e engenharia, ano 4, n.10, quadrimestral, jan/abril, 2003, ISSN 1806-6097 
Franklin GL (1945) Preparation of thin sections of synthetic resins and wood - resin composites, and a new macerating method for wood. Nature 1945; 155(3924):51. http://dx.doi.org/10.1038/155051a0

Galvão, APM; Jankowsky, IP (1985) Secagem racional da madeira. São Paulo: Nobel, 1985. 111p

Garcia, RA \& Marinonio, GB (2016) Variação da cor da madeira de teca em função da densidade e do teor de extrativos Floresta e Ambiente. Seropédica, v. 23, n. 1, p. 124 - 134, 2016

Globalwood (2013) Globalwood-International Log \& Sawnwood Prices, 16-31th, January, 2013. (http://www.globalwood.org/market/timber prices 2013/aaw20130102.htm)

Gonçalves, MPM; Coffer, R; Carvalho, AM; Garcia, RA (2007) Variação radial da densidade básica e comprimento das fibras da madeira de Tectona grandis L. Floresta e Ambiente, Rio de Janeiro, v.14, n.1, p.70-75, 2007.

Higuchi, N (1979) Informações básicas para o manejo florestal da Tectona grandis L.f. (Teca) introduzida no Alto Jauru. Cuiabá: Fundação Universidade Federal de Mato Grosso/Departamento de Engenharia Florestal. 92p

IAWA Committee on Nomenclature (1989). IAWA list of microscopic features for hardwood identification. IAWA

Bulletin 10: 221-332

IBA (2018) Relatório 2017 - Base 2016. In. Indústria Brasileira de Árvores, 2018, Capítulo VIII, p. 73

Instituto Florestal (2017) Mapa Pedológico do Estado de São Paulo, revisado e atualizado (http://iflorestal.sp.gov.br/2017/09/26/mapa-pedologico-do-estado-de-sao-paulo-revisado-e-ampliado/),

KMZ para Google Earth

ITTO (2004) Tropical Forest Update. International Tropical Timber Organization, Japão, Volume 14, número 1. 2004, pág. 04

Jankowsky, IP (2009) Metodologia Simplificada para Indicação de Programas de Secagem. 2009. 129p. Tese (Livredocência) - Escola Superior de Agricultura “Luiz de Queiroz”, Universidade de São Paulo, Piracicaba, 2009

Josue, J \& Imiyabir, Z (2011) Anatomical features, quality and mechanical properties of 15-year-old Tectona grandis (teak) planted in Sabah. In: Tan et al. (eds) Proceedings of "ITTO Project on improving utilization and value adding of plantation timbers from sustainable sources in Malaysia Project No PD 306/04(1)”, Malaysia, pp 11-14

Jozsa, LA \& Middleton, GR (1994) A discussion of wood quality attributes and their practical implications Forintek Canada Corp. Western Laboratory, 2665 East Mall Vancouver, B.C. V6T 1W5 Special Publication No. SP-34, Dezembro, 1994

Kaosa-Ard, A (1983) Teak (Tectona grandis L. f.) natural distribution and related factors. Silvicultura. São Paulo, 30 (2): 173-179

Katwal, R. P. S. (2005).Teak in India: Status, Prospects and Perspectives. In: Quality timber Products of Teak from Sustainable Forest Management. Bhat, K. M., Nair, K. K. N., Bhat, K. V., Muralidharan, E. M. and Sharma, J. K. (Eds.). Kerala Forest Research Institute, Peechi, Kerala, India, pp. 1-18.

Keating, WG \& Bolza, E (1982) Characteristics, Properties and Use of Timbers: South-East of Asia, Northern

Australia and Pacific. Volume 1, Inkata Press Proprietary Ltd., Melbourne, Sydney \& London, 362 p.

Keine, S (1997) Avaliação do processo de secagem de madeira em estufa com banho de vapor / Sandro Keine Florianópolis: UFLSC, (1997), Dissertação (Mestrado em Engenharia Mecânica) - Universidade Federal de Santa Catarina, Florianópolis, 1997, 215 p

Klock, U \& Andrade, AS (2013) Química da Madeira, Universidade Federal do Paraná, Setor de Ciências Agrárias, Departamento de Engenharia e Tecnologia Florestal, 87 pág.

Kokutse, AD; Stokes, A; Kokutse NK; Kokou, K (2010) Which factors most influence heartwood distribution and radial growth in plantation teak? Ann. For. Sci. 67 (2010) 407 disponível online em: www.afs-journal.org 
IUFRO (2017) Kollert, W; Kleine, M (eds.) The Global Teak Study. Analysis, Evaluation and Future Potential of Teak Resources IUFRO World Series Volume 36. Vienna. 108 p

Latorraca, JVF \& Albuquerque, CEC (2000) Efeito do rápido crescimento sobre as propriedades da madeira, Floresta e Ambiente, volume 7, número 1, pág. 279 - 291, janeiro/dezembro 2000

Lima, IL, Garcia R, Longui, EL \& Florsheim, SMB (2011) Dimensões anatômicas da madeira de Tectona grandis Linn, em função do espaçamento e da posição radial do tronco, Sci. For., Piracicaba, v. 39, n. 89, p. 61-68, mar 2011

Martins, M (2008) Ensaios de simulação de uso em pisos de Eucalyptus cloęiana F. Muell, Eucalyptus microcorys F. Muell e Corymbia maculata Hook / Marcelo Martins - Lavras: UFLA, Dissertação de Mestrado, 2008, 48 p.

Masserann, C ; Mariaux, A (1985) Anisotropie de retrait et structure du bois. Recherche de l'influence des caractéres morphologiques transverses des fibres. Bois et Forêts des Tropiques, n.209, p.35-47, 1985

Matricardi, WA (1988) Efeitos dos fatores do solo sobre o desenvolvimento da Teca (Tectona grandis L. f.) cultivada na Grande Cáceres - Mato Grosso. Piracicaba: ESALQ. Dissertação (Mestrado). 135p

Micco, V de; Balzano, A; Wheeler, EA; Baas, P (2016) Tyloses and gums: a review of structure, function and occurrence of vessel occlusions. IAWA Journal, v.37, n.2, p.186 - 205, 2016

Miranda, I; Sousa, V.; Pereira, H (2011) Wood properties of teak (Tectona grandis) from a mature unmanaged stand in East Timor, Journal of Wood Science, V. 57, p. 171-178.

Motta, JP (2011) Propriedades tecnológicas da madeira de Tectona grandis L.f. proveniente do Vale do Rio Doce, Minas Gerais / Javan Pereira Motta - Jerônimo Monteiro: UFES, Dissertação (Mestrado em Ciências Florestais) - UFES, Jerônimo Monteiro/ES, $113 \mathrm{p}$

Motta, JP, Oliveira, JTS, Braz, Duarte, APC, Alves, RC (2014) Caracterização da madeira de quatro espécies florestais, Ciência Rural, Santa Maria, v.44, n.12, p.2186-2192, dez, 2014

Moya, R, Berrocal, A, Serrano, JR \& Tomazello Filho, M (2009) Variación radial de la anatomía, densidad y durabilidad de la madera de teca (Tectona grandis) procedente de dos calidades de sitio y dos regiones climáticas de Costa Rica, Instituto Nacional de Investigación y Tecnología Agraria y Alimentaria (INIA), Investigación Agraria: Sistemas y Recursos Forestales 2009 18(2), 119-131

Narayanan, C; Chawhaan, PH: Mandal, AK (2009) Inheritance Pattern of Growth and Wood Traits in Teak (Tectona grandis L.f.) - Silvae Genetica (2009) 58-3, 97-101, dezembro 2009

Oliveira, JTS, Thomazello Filho, M \& Fiedler, NC (2010) Avaliação da retratibilidade da madeira de sete espécies de Eucalyptus, Revista Árvore, Viçosa-MG, v.34, n.5, p.929-936, 2010

Palanisamy, K, Hegde, M \& Yi, J (2009) Teak (Tectona grandis) A renowned commercial timber species, Journal of Forest Science, vol. 25, no1, pp. 1-24

Pérez Cordero, LD \& Kanninen, M (2003) Heartwood, sapwood and bark content, and wood dry density of young and mature teak (Tectona grandis) trees grown in Costa Rica. Silva Fennica 37(1): 45-54

Pettersen, RC (1984) The Chemical Composition of wood. U.S. Department of Agriculture, Forest Service, Forest Products Laboratory, Madison, WI 53705, In: The Chemistry of Solid Wood Chapter 2, pp 57-126

Pimentel, M. M., Selegato, P. A. M., Garcia, J. N., \& Lima, I. L. de. (2008). Variação de propriedades da madeira de Tectona grandis Linn. F. (teca) em função do espaçamento e da posição radial na tora. IF Série Registros. São Paulo.

Pinto, ML (2007) Propriedades e características da madeira de teca (Tectona grandis) em função da idade / Márcio de Lara Pinto, Tese-Doutorado. Programa de Pós-graduação em Engenharia Civil - PPGEC, UFSC, Florianópolis, SC: Márcio de Lara Pinto 2007, 124 p 
Polato, R, Laming, PB \& Sierra-Alvarez, R (2005), Assessment of some wood characteristics of Teak of Brazilian Origin, In: Quality Timber Products of Teak from Sustainable Forest Management, Kerala Forest Research Institute, International Tropical Timber Organization, p. 257-265

Premrasmi, Thanom, Dietrichs. H. H., (1967). Nature and distribution of extractives in Teak (Tectona grandis Linn.) from Thailand. Natural History Bulletin 22 (1 \& 2): 1-14.

QMS (1999) QMS Tree Ring Analyzer Model QTRS-01X. Users Guide. Quintek Measurement Systems, Knoxville, TN, 1999

Rachmawati, H, Iriantono, D \& Hansen CP (2002) Tectona grandis L.f. DFSC, Humlebaek: Danida Forest Seed Centre. $2 \mathrm{p}$.

Ribeiro, RAS, Ribeiro, MGS, Rocha, JS, Bessa, TMF, Pontes, CLF \& Lima, VMO (2010) Efeito do pesos específicos na resistência ao cisalhamento de vigas de madeiras tropicais In: XII Ebramem - Encontro Brasileiro em Madeiras e em Estruturas de Madeira, Lavras, Jul, 2010

Richter, HG, Leithoff, H \& Sonntag, U (2005) Characterisation and Extension of Juvenile Wood in Plantation Grown Teak (Tectona grandis L.f.) from Ghana In: Quality Timber Products of Teak from Sustainable Forest Management, Kerala Forest Research Institute, International Tropical Timber Organization, p. $266-272$

Rocha, HF; Leonardo, FVS; Oliveira, AC (2015) Plantios comerciais de Tectona grandis L.f. no Brasil, Multitemas, Campo Grande, MS, n. 48, p. 9-28, jul/dez, 2015

Roque, RM; Ledezma, RM (2003) Efecto del espaciamiento en plantación sobre dos propiedades físicas de madera de teca a lo largo del fuste. Madera y Bosques, Heredia, v. 9, n. 2, p. 15-27, 2003

Roque, RM; Tomazello Filho, M (2009) Variação radial da estrutura anatômica do lenho de árvores de Gmelina arborea em diferentes condições de clima e de manejo na Costa Rica. Scientia Forestalis, Piracicaba, v.37, n.83, p.273-85, 2009.

Sanquetta, MNI; Sanquetta, CR; Dalla Corte, AP (2014) Incremento diamétrico e percentuais de cerne e de casca em povoamentos de Tectona grandis L.F. no Sudeste do Pará, Enciclopédia Biosfera, Centro Científico Conhecer Goiânia, v.10, n.18; p. 2014

Sass, JE (1951) Botanical Microtechniche. Iwoa: The Iowa State College Press; Ames, 1951, 326p

Senft, JF; Quanci, MJ; Bendtsen, BA (1986) Property profile of 60-year-old Douglas - Fir. In: A Technical Workshop:

Juvenile Wood-What does it mean to Forest Management and Forest Products, 1985, Washington. Proceedings: Madison: Forest Products Research Society, p. 17-28

Silva, DA; Trugilho, PF (2003) Comportamento dimensional da madeira de cerne e alburno utilizando-se a metodologia de análise de imagem submetida a diferentes temperaturas. Revista Cerne, Lavras, v.09, n.01, p.056-65, 2003

Simpson, WT (1999) Wood Handbook - Wood as an engineering material. Gen. Tech. Rep. FPL-GTR-113. Madison,

WI: U.S. Department of Agriculture, Forest Service, Forest Products Laboratory. 463 p.

Soerianegara, I \& Lemmens, RHMJ (Eds) (1993) Timber trees: Major Commercial Timbers. Plant Resources of SouthEast Asia 5 (1). Pudoc Scientific Publishers, Wageningen, 610 p.

Soler, LS (2014) Propriedades de pisos maciços de teca e bracatinga. TCC em Engenharia Industrial Madeireira - do Curso de Engenharia Industrial Madeireira, Departamento de Engenharia e Tecnologia Florestal, Setor de Ciências Agrárias, da Universidade Federal do Paraná, 2014, 42 pág.

Szücs, CA; Terezo, RF; do Valle, A \& Moraes, PD (2015) Estruturas de Madeira, Universidade Federal de Santa Catarina, Centro Tecnológico, Departamento de Engenharia Civil, Março, 2015, 147 pág. 
Tanaka N, Hamazaki T, Vacharangkura T. (1998) Distribution, Growth and site requirements of teak. Japan Agricultural Research Quarterly 1998; 32: 65-77

Tewari, VP \& Mariswamy, KM (2013) Heartwood, sapwood and bark content of teak trees grown in Karnataka, India, Journal of Forestry Research (2013) 24(4): 721-725

Thulasidas, PK \& Baillères, H (2017) Wood Quality for Advanced Uses of Teak from Natural and Planted Forests In: Kollert, W; Kleine, M (eds.) (2017) The Global Teak Study. Analysis, Evaluation and Future Potential of Teak Resources IUFRO World Series Volume 36. Vienna. Chapter6, pág. 73 a 81

Thulasidas, PK \& Bhat, KM (2012) Mechanical properties and wood structure characteristics of 35-year old homegarden teak from wet and dry localities of Kerala, India in comparison with plantation teak, J Indian Acad Wood Sci, June 2012, 9 (1): 23-32

Tropicos. Missouri Botanical Garden (2018) Disponível em: <http://www.tropicos.org>. Acesso em: 07 jul. 2018.

Troup, R.S. (1921) The Silviculture of Indian Trees - Volume II Leguminosae (Caesalpinieae) to Verbenaceae. Oxford at the Clarendon Press, 783 pp.

Vieira, AH; Rocha, RB; Bentes-Gama, M de M; Locatelli, M (2008) Desempenho de teca (Tectona grandis) em plantio adensado no Estado de Rondônia. Porto Velho: EMBRAPA Rondônia, 2008. 14 p (Boletim de Pesquisa e Desenvolvimento no. 56)

Vincent, L; Moret, AY; Jerez, M (2000) Comparación de algunos regimens de espesura en plantaciones de teca en el área experimental de la Reserva Forestal de Caparo, Venezuela. Revista Forestal Venezolana, 44 (2): 87-95

Windeisen, E, Klassen, A, Wagener, G, (2003) On the chemical characterization of plantation teakwood from Panama. HolzalsRoh- und Werkstoff 61: 416-418. (doi:10.1007/s00107-003-0425-2).

Zahabu, E. Tumaini, R., Chamshama, S., Athumani Omari, S, Malimbwi, R.E (2015) Effect of Spacing Regimes on Growth, Yield, and Wood Properties of Tectona grandis at Longuza Forest Plantation, Tanzania International Journal of Forestry Research, 2015:1-6. 


\section{APÊNDICES}

APÊNDICE A. Programas de secagem simplificada para todos os tratamentos

A1. Programa de secagem para a madeira de teca plantada em Angatuba/SP, com 9,4 anos de idade

\begin{tabular}{|l|r|l|}
\hline \multicolumn{2}{|l|}{ Parâmetros } \\
\hline Ti & $\mathbf{4 8 , 3 1 8 4 8 0 1 1} \mathrm{Ti}=27,9049+0,7881 \mathrm{~T}_{2}+419,0254 \mathrm{~V}_{1}+1,9483 \mathrm{R}_{2}$ \\
\hline Tf & $\mathbf{7 2 , 2 8 9 5 7 9 6 7} \mathrm{Tf}=49,2292+1,1834 \mathrm{~T}_{2}+273,8685 \mathrm{~V}_{2}+1,0754 \mathrm{R}_{1}$ \\
\hline PS & $\mathbf{2 , 7 3 6 9 2 1 0 2 2} \mathrm{PS}=1,4586-30,4418 \mathrm{~V}_{3}+42,9653 \mathrm{~V}_{1}+0,1424 \mathrm{R}_{3}$ \\
\hline
\end{tabular}

Programa de secagem para madeira de teca (Tectona grandis) plantada em Angatuba/SP com 9,4 anos de idade.

\begin{tabular}{|c|c|c|c|c|c|}
\hline \multicolumn{1}{l|}{ para umidade final de $8 \%$} \\
\hline UMIDADE & Ts $\left({ }^{\circ} \mathbf{C}\right)$ & Tu $\left({ }^{\circ} \mathbf{C}\right)$ & UR $(\%)$ & UE $(\%)$ & PS \\
\hline Aquecimento & 48,3 & 47,3 & 95 & 21,6 & $* *$ \\
\hline Acima de 50 & 48,3 & 44,8 & 81 & 15,0 & $>3,3$ \\
\hline 50 & 48,3 & 44,8 & 81 & 15,0 & 3,3 \\
\hline 45 & 48,3 & 44,4 & 79 & 14,0 & 3,2 \\
\hline 40 & 48,3 & 43,9 & 76 & 13,0 & 3,1 \\
\hline 35 & 48,3 & 42,8 & 71 & 11,9 & 2,9 \\
\hline 30 & 48,3 & 40,5 & 61 & 11,0 & 2,7 \\
\hline 25 & 54,4 & 45,2 & 58 & 9,1 & 2,7 \\
\hline 20 & 60,3 & 48,3 & 50 & 7,3 & 2,7 \\
\hline 15 & 66,3 & 48,3 & 37 & 5,5 & 2,7 \\
\hline 10 & $\mathbf{7 2 , 3}$ & 46,3 & 25 & 3,7 & 2,7 \\
\hline 5 & $\mathbf{7 2 , 3}$ & 42,3 & 17 & 2,5 & 2,0 \\
\hline Uniformização & $\mathbf{7 2 , 3}$ & $\mathbf{5 6 , 5}$ & $\mathbf{4 5 , 5}$ & $\mathbf{6}$ & $* *$ \\
\hline Condicionamento & $\mathbf{7 2 , 3}$ & $\mathbf{6 7 , 5}$ & $\mathbf{7 9}$ & $\mathbf{1 2}$ & $* *$ \\
\hline
\end{tabular}

A2. Programa de Secagem para a madeira de teca plantada em Glória D’Oeste/MT, com 9,5 anos de idade

\begin{tabular}{|l|l|l|}
\hline \multicolumn{2}{|c|}{ Parâmetros } \\
\hline Ti & $\mathbf{4 6 , 9 9 1 6 4 4 5 2} \mathrm{Ti}=27,9049+0,7881 \mathrm{~T}_{2}+419,0254 \mathrm{~V}_{1}+1,9483 \mathrm{R}_{2}$ \\
\hline Tf & $\mathbf{7 0 , 8 2 2 0 6 8 7 8} \mathrm{Tf}=49,2292+1,1834 \mathrm{~T}_{2}+273,8685 \mathrm{~V}_{2}+1,0754 \mathrm{R}_{1}$ \\
\hline PS & $\mathbf{2 , 6 0 7 3 9 6 1 1 6} \mathrm{PS}=1,4586-30,4418 \mathrm{~V}_{3}+42,9653 \mathrm{~V}_{1}+0,1424 \mathrm{R}_{3}$ \\
\hline
\end{tabular}

Programa de secagem para madeira de teca (Tectona grandis) plantada em Glória D'Oeste/MT com 9,5 anos de idade.

\begin{tabular}{|c|c|c|c|c|c|}
\hline \multicolumn{6}{|c|}{ para umidade final de $8 \%$} \\
\hline UMIDADE & Ts $\left({ }^{\circ} \mathrm{C}\right)$ & $\mathrm{Tu}\left({ }^{\circ} \mathrm{C}\right)$ & UR (\%) & UE (\%) & PS \\
\hline Aquecimento & 47,0 & 46,0 & 95 & 21,5 & *** \\
\hline Acima de 50 & 47,0 & 43,5 & 81 & 15,0 & 3,3 \\
\hline 50 & 47,0 & 43,5 & 81 & 15,0 & 3,3 \\
\hline 45 & 47,0 & 43,0 & 79 & 14,1 & 3,2 \\
\hline 40 & 47,0 & 42,5 & 76 & 13,3 & 3,0 \\
\hline 35 & 47,0 & 42,0 & 74 & 12,4 & 2,8 \\
\hline 30 & 47,0 & 41,0 & 69 & 11,5 & 2,6 \\
\hline 25 & 52,9 & 44,9 & 61 & 9,6 & 2,6 \\
\hline 20 & 58,9 & 47,9 & 53 & 7,7 & 2,6 \\
\hline 15 & 64,9 & 48,9 & 42 & 5,8 & 2,6 \\
\hline 10 & 70,8 & 49,8 & 37 & 3,8 & 2,6 \\
\hline 5 & 70,8 & 46,8 & 29 & 2,5 & 2,0 \\
\hline Uniformização & 70,8 & 54 & 45 & 6 & $* *$ \\
\hline Condicionamento & 70,8 & 65 & 79 & 12 & $* *$ \\
\hline
\end{tabular}


A3. Programa de Secagem para a madeira de teca plantada em Porto Espiridião/MT, com 14,4 anos de idade

\begin{tabular}{|c|c|c|c|c|c|}
\hline & Parâmetros & & & & \\
\hline & & & & & \\
\hline $\mathbf{T i}$ & \multicolumn{5}{|c|}{$46,33165166 \mathrm{Ti}=27,9049+$} \\
\hline Tf & \multicolumn{5}{|c|}{$70,567034 \mathrm{Tf}=49,2292+1,1834 \mathrm{~T}_{2}+2$} \\
\hline PS & \multicolumn{5}{|l|}{$2,53565701 \mathrm{P}$} \\
\hline \multicolumn{6}{|c|}{$\begin{array}{c}\text { Programa de secagem para madeira de teca (Tectona grandis) plantada em Porto } \\
\text { Espiridião/MT com } 14,4 \text { anos de idade. }\end{array}$} \\
\hline \multicolumn{6}{|c|}{ para umidade final de $8 \%$} \\
\hline UMIDADE & Ts $\left({ }^{\circ} \mathrm{C}\right)$ & $\mathrm{Tu}\left({ }^{\circ} \mathrm{C}\right)$ & UR (\%) & UE (\%) & PS \\
\hline Aquecimento & 46,3 & 45,3 & 94 & 21,3 & $* *$ \\
\hline Acima de 50 & 46,3 & 42,8 & 81 & 15,0 & $>3,3$ \\
\hline 50 & 46,3 & 42,8 & 81 & 15,0 & 3,3 \\
\hline 45 & 46,3 & 42,3 & 79 & 14,2 & 3,2 \\
\hline 40 & 46,3 & 41,8 & 76 & 13,4 & 3,0 \\
\hline 35 & 46,3 & 41,3 & 74 & 12,6 & 2,8 \\
\hline 30 & 46,3 & 40,8 & 69 & 11,8 & 2,5 \\
\hline 25 & 52,4 & 45,4 & 61 & 9,9 & 2,5 \\
\hline 20 & 58,4 & 48,4 & 53 & 7,9 & 2,5 \\
\hline 15 & 64,5 & 48,5 & 41 & 5,9 & 2,5 \\
\hline 10 & 70,6 & 46,6 & 33 & 3,9 & 2,5 \\
\hline 5 & 70,6 & 46,6 & 27 & 2,8 & 1,8 \\
\hline Uniformização & 70,6 & 54 & 45 & 6 & $* *$ \\
\hline Condicionamento & 70,6 & 65 & 79 & 12 & $* *$ \\
\hline
\end{tabular}

A4. Programa de Secagem para a madeira de teca plantada em Rosário D’Oeste /MT, com 18,7 anos de idade

\begin{tabular}{|c|c|c|c|c|c|}
\hline & Parâmetros & & & & \\
\hline & & & & & \\
\hline Ti & \multicolumn{5}{|c|}{$45,16521757 \mathrm{Ti}$} \\
\hline Tf & \multicolumn{5}{|c|}{69,41417697 Tf } \\
\hline PS & \multicolumn{5}{|c|}{$\mathbf{2 , 4 3 8 7 7 3 9 5 5} \mathrm{PS}=1,4586-30,4418 \mathrm{~V}_{3}+42,9653 \mathrm{~V}_{1}+0,1424 \mathrm{R}_{3}$} \\
\hline \multicolumn{6}{|c|}{$\begin{array}{l}\text { Programa de secagem para madeira de teca (Tectona grandis) plantada em Rosário } \\
\text { D'Oeste/MT com 18,7 anos de idade. }\end{array}$} \\
\hline \multicolumn{6}{|c|}{ para umidade final de $8 \%$} \\
\hline UMIDADE & Ts $\left({ }^{\circ} \mathrm{C}\right)$ & Tu $\left({ }^{\circ} \mathrm{C}\right)$ & UR (\%) & UE (\%) & PS \\
\hline Aquecimento & 45,2 & 44,2 & 94 & 21,2 & *** \\
\hline Acima de 50 & 45,2 & 41,7 & 81 & 15,0 & 3,3 \\
\hline 50 & 45,2 & 41,7 & 81 & 15,0 & 3,3 \\
\hline 45 & 45,2 & 41,2 & 79 & 14,3 & 3,1 \\
\hline 40 & 45,2 & 40,7 & 76 & 13,7 & 2,9 \\
\hline 35 & 45,2 & 40,2 & 73 & 13,0 & 2,7 \\
\hline 30 & 45,2 & 39,7 & 71 & 12,3 & 2,4 \\
\hline 25 & 51,2 & 44,2 & 65 & 10,3 & 2,4 \\
\hline 20 & 57,3 & 47,8 & 57 & 8,2 & 2,4 \\
\hline 15 & 63,4 & 47,4 & 40 & 6,2 & 2,4 \\
\hline 10 & 69,4 & 45,4 & 27 & 4,1 & 2,4 \\
\hline 5 & 69,4 & 39,4 & 16 & 2,5 & 2,0 \\
\hline Uniformização & 69,4 & 54 & 45 & 6 & $* *$ \\
\hline Condicionamento & 69,4 & 65 & 79 & 12 & $* *$ \\
\hline
\end{tabular}


APENDICE B. Resumo das análises de variância para todos os parâmetros, em função das diferentes idades de plantio de teca

B1. Análise de variância do volume médio por árvore (alpha $=0,05)$

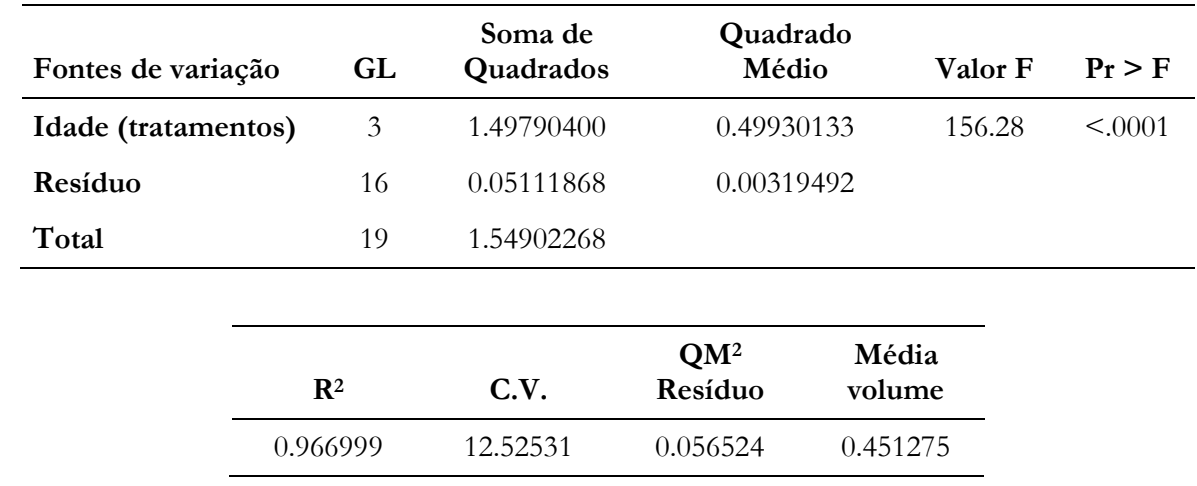

B2. Análise de variância dos volumes individuais médios por árvore (medula, cerne, alburno, casca e total)

Volume medula (alpha $=0,05)$ :

\begin{tabular}{lccccc}
\hline Fontes de variação & GL & $\begin{array}{c}\text { Soma de } \\
\text { Quadrados }\end{array}$ & $\begin{array}{c}\text { Quadrado } \\
\text { Médio }\end{array}$ & Valor F & Pr > F \\
\hline Idade (tratamentos) & 3 & 980386.558 & 326795.519 & 13.59 & $<.0001$ \\
Resíduo & 16 & 384628.408 & 24039.276 & & \\
Total & 19 & 1365014.967 & & & \\
\hline
\end{tabular}

\begin{tabular}{cccc}
\hline $\mathbf{R}^{2}$ & C.V. & $\mathbf{Q M}^{2}$ & $\begin{array}{c}\text { Média volume } \\
\text { medula }\end{array}$ \\
\hline 0.718224 & 18.31753 & 155.0460 & 846.4355 \\
\hline
\end{tabular}

Volume cerne (alpha $=0,05)$ :

\begin{tabular}{lccccc}
\hline Fontes de variação & GL & $\begin{array}{c}\text { Soma de } \\
\text { Quadrados }\end{array}$ & $\begin{array}{c}\text { Quadrado } \\
\text { Médio }\end{array}$ & Valor F & $\operatorname{Pr}>$ F \\
\hline Idade (tratamentos) & 3 & 569358451918 & 189786150639 & 125.42 & $<.0001$ \\
Resíduo & 16 & 24211453916 & 1513215869.7 & & \\
Total & 19 & 593569905834 & & & \\
\hline
\end{tabular}

\begin{tabular}{cccc}
\hline $\mathbf{R}^{2}$ & C.V. & $\mathbf{Q M}^{2}$ & $\begin{array}{c}\text { Média volume } \\
\text { cerne }\end{array}$ \\
\hline 0.959210 & 17.87918 & 38900.08 & 217571.9 \\
\hline
\end{tabular}


Volume alburno (alpha $=0,05)$ :

\begin{tabular}{|c|c|c|c|c|c|c|}
\hline Fontes de variação & GL & $\begin{array}{c}\text { Soma de } \\
\text { Quadrados }\end{array}$ & \multicolumn{2}{|c|}{$\begin{array}{l}\text { Quadrado } \\
\text { Médio }\end{array}$} & Valor F & $\operatorname{Pr}>$ F \\
\hline Idade (tratamentos) & 3 & 156185115698 & \multicolumn{2}{|c|}{52061705233} & 94.03 & $<.0001$ \\
\hline Resíduo & 16 & 8858281518.5 & \multirow{2}{*}{\multicolumn{2}{|c|}{553642594.91}} & & \\
\hline \multirow[t]{3}{*}{ Total } & 19 & 165043397217 & & & & \\
\hline & $\mathbf{R}^{2}$ & C.V. & $\mathbf{Q M}^{2}$ & \multicolumn{2}{|c|}{$\begin{array}{l}\text { Média volume } \\
\text { alburno }\end{array}$} & \\
\hline & 0.946328 & 12.01164 & 23529.61 & \multicolumn{2}{|c|}{195890.0} & \\
\hline
\end{tabular}

Volume casca (alpha $=0,05)$ :

\begin{tabular}{lccccc}
\hline Fontes de variação & GL & $\begin{array}{c}\text { Soma de } \\
\text { Quadrados }\end{array}$ & $\begin{array}{c}\text { Quadrado } \\
\text { Médio }\end{array}$ & Valor F & $\operatorname{Pr}>$ F \\
\hline Idade (tratamentos) & 3 & 7595208460 & 2531736153 & 119.01 & $<.0001$ \\
Resíduo & 16 & 340387179 & 21274199 & & \\
Total & 19 & 7935595639 & & & \\
\hline
\end{tabular}

\begin{tabular}{cccc}
\hline $\mathbf{R}^{2}$ & C.V. & $\mathbf{Q M}^{2}$ & $\begin{array}{c}\text { Média volume } \\
\text { casca }\end{array}$ \\
\hline 0.957106 & 12.47761 & 4612.396 & 36965.38 \\
\hline
\end{tabular}

Volume total (alpha $=0,05)$ :

\begin{tabular}{lccccc}
\hline Fontes de variação & GL & $\begin{array}{c}\text { Soma de } \\
\text { Quadrados }\end{array}$ & $\begin{array}{c}\text { Quadrado } \\
\text { Médio }\end{array}$ & Valor F & $\operatorname{Pr}>$ F \\
\hline Idade (tratamentos) & 3 & $1.4980044 \mathrm{E} 12$ & 499334796389 & 156.33 & $<.0001$ \\
Resíduo & 16 & 51105989583 & 3194124348.9 & & \\
Total & 19 & $1.5491104 \mathrm{E} 12$ & & & \\
\hline
\end{tabular}

\begin{tabular}{cccc}
\hline $\mathbf{R}^{2}$ & C.V. & $\mathbf{Q M}^{2}$ & $\begin{array}{c}\text { Média } \\
\text { volume total }\end{array}$ \\
\hline 0.967009 & 12.52379 & 56516.58 & 451273.8 \\
\hline
\end{tabular}

B3. Análise de variância da excentricidade da medula (alpha $=0,05)$

\begin{tabular}{lccccc}
\hline Fontes de variação & GL & $\begin{array}{c}\text { Soma de } \\
\text { Quadrados }\end{array}$ & $\begin{array}{c}\text { Quadrado } \\
\text { Médio }\end{array}$ & Valor F & Pr > F \\
\hline Idade (tratamentos) & 3 & 113.5037552 & 37.8345851 & 6.95 & 0.0002 \\
Resíduo & 112 & 609.6484000 & 5.4432893 & & \\
Total & 115 & 723.1521552 & & & \\
\hline
\end{tabular}

\begin{tabular}{cccc}
\hline $\mathbf{R}^{2}$ & C.V. & $\mathbf{Q M}^{2}$ & $\begin{array}{c}\text { Média } \\
\text { excentricidade }\end{array}$ \\
\hline 0.156957 & 37.48967 & 2.333086 & 6.223276 \\
\hline
\end{tabular}


B4. Análise de variância da densidade básica (alpha $=0,05)$

\begin{tabular}{lrrrrr}
\hline Fontes de variação & GL & $\begin{array}{r}\text { Soma de } \\
\text { Quadrados }\end{array}$ & $\begin{array}{r}\text { Quadrado } \\
\text { Médio }\end{array}$ & Valor F & Pr > F \\
\hline Idade (tratamentos) & 3 & 0.04242576 & 0.01414192 & 8.74 & 0.0002 \\
Resíduo & 36 & 0.05824631 & 0.00161795 & & \\
Total & 39 & 0.10067207 & & & \\
\hline
\end{tabular}

\begin{tabular}{cccc}
\hline $\mathbf{R}^{2}$ & C.V. & $\mathbf{Q M}^{2}$ & $\begin{array}{c}\text { Média } \\
\text { densidade } \\
\text { básica }\end{array}$ \\
\hline 0.421425 & 7.391628 & 0.040224 & 0.544180 \\
\hline
\end{tabular}

B5. Análise de variância da retratibilidade (radial, tangencial, anisotropia, longitudinal e volumétrica) Retratibilidade radial (alpha $=0,05)$ :

\begin{tabular}{lccccc}
\hline Fontes de variação & GL & $\begin{array}{c}\text { Soma de } \\
\text { Quadrados }\end{array}$ & $\begin{array}{c}\text { Quadrado } \\
\text { Médio }\end{array}$ & Valor F & $\operatorname{Pr}>$ F \\
\hline Idade (tratamentos) & 3 & 30.75741959 & 10.25247320 & 45.43 & $<.0001$ \\
Resíduo & 236 & 53.25901804 & 0.22567381 & & \\
Total & 239 & 84.01643763 & & & \\
\hline
\end{tabular}

\begin{tabular}{cccc}
\hline $\mathbf{R}^{2}$ & C.V. & $\mathbf{Q M}^{2}$ & $\begin{array}{c}\text { Média } \\
\text { retratibilidade } \\
\text { radial }\end{array}$ \\
\hline 0.366088 & 24.45289 & 0.475051 & 1.942720 \\
\hline
\end{tabular}

Retratibilidade tangencial (alpha $=0,05)$ :

\begin{tabular}{lccccc}
\hline Fontes de variação & GL & $\begin{array}{c}\text { Soma de } \\
\text { Quadrados }\end{array}$ & $\begin{array}{c}\text { Quadrado } \\
\text { Médio }\end{array}$ & Valor F & Pr > F \\
\hline Idade (tratamentos) & 3 & 337.6044737 & 112.5348246 & 68.51 & $<.0001$ \\
Resíduo & 236 & 387.6584699 & 1.6426206 & & \\
Total & 239 & 725.2629436 & & & \\
\hline
\end{tabular}

\begin{tabular}{cccc}
\hline $\mathbf{R}^{2}$ & C.V. & $\mathbf{Q M}^{2}$ & $\begin{array}{c}\text { Média } \\
\text { retratibilidade } \\
\text { tangencial }\end{array}$ \\
\hline 0.465493 & 33.57053 & 1.281648 & 3.817776 \\
\hline
\end{tabular}


Anisotropia (alpha $=0,05)$ :

\begin{tabular}{lccccc}
\hline Fontes de variação & GL & $\begin{array}{c}\text { Soma de } \\
\text { Quadrados }\end{array}$ & $\begin{array}{c}\text { Quadrado } \\
\text { Médio }\end{array}$ & Valor F & $\operatorname{Pr}>$ F \\
\hline Idade (tratamentos) & 3 & 15.68261191 & 5.22753730 & 16.03 & $<.0001$ \\
Resíduo & 236 & 76.96582261 & 0.32612637 & & \\
Total & 239 & 92.64843452 & & & \\
\hline
\end{tabular}

\begin{tabular}{cccc}
\hline $\mathbf{R}^{2}$ & C.V. & $\mathbf{Q M}^{2}$ & $\begin{array}{c}\text { Média } \\
\text { anisotropia }\end{array}$ \\
\hline 0.169270 & 29.13108 & 0.571075 & 1.960363 \\
\hline
\end{tabular}

Retratibilidade longitudinal (alpha $=0,05)$ :

\begin{tabular}{lccccc}
\hline Fontes de variação & GL & $\begin{array}{c}\text { Soma de } \\
\text { Quadrados }\end{array}$ & $\begin{array}{c}\text { Quadrado } \\
\text { Médio }\end{array}$ & Valor F & Pr > F \\
\hline Idade (tratamentos) & 3 & 0.01300696 & 0.00433565 & 0.51 & 0.6743 \\
Resíduo & 236 & 1.99800469 & 0.00846612 & & \\
Total & 239 & 2.01101165 & & & \\
\hline
\end{tabular}

\begin{tabular}{cccc}
\hline $\mathbf{R}^{2}$ & C.V. & $\mathbf{Q M}^{2}$ & $\begin{array}{c}\text { Média } \\
\text { retratibilidade } \\
\text { longitudinal }\end{array}$ \\
\hline 0.006468 & 32.66218 & 0.092012 & 0.281707 \\
\hline
\end{tabular}

Retratibilidade volumétrica (alpha $=0,05)$ :

\begin{tabular}{lrrrrr}
\hline Fontes de variação & GL & $\begin{array}{r}\text { Soma de } \\
\text { Quadrados }\end{array}$ & $\begin{array}{r}\text { Quadrado } \\
\text { Médio }\end{array}$ & Valor F & Pr > F \\
\hline Idade (tratamentos) & 3 & 537.359070 & 179.119690 & 78.20 & $<.0001$ \\
Resíduo & 236 & 540.549335 & 2.290463 & & \\
Total & 239 & 1077.908405 & & & \\
\hline
\end{tabular}

\begin{tabular}{cccc}
\hline $\mathbf{R}^{2}$ & C.V. & $\mathbf{Q M}^{2}$ & $\begin{array}{c}\text { Média } \\
\text { retratibilidade } \\
\text { volumétrica }\end{array}$ \\
\hline 0.498520 & 25.45676 & 1.513428 & 5.945091 \\
\hline
\end{tabular}


B6. Análise de variância dos elementos anatômicos - fibra (comprimento fibra, diâmetro total, diâmetro do lúme e espessura da parede)

Comprimento fibra no alburno (alpha $=0,05)$ :

\begin{tabular}{lccccc}
\hline Fontes de variação & GL & $\begin{array}{c}\text { Soma de } \\
\text { Quadrados }\end{array}$ & $\begin{array}{c}\text { Quadrado } \\
\text { Médio }\end{array}$ & Valor F & Pr > F \\
\hline Idade (tratamentos) & 3 & 11588706.23 & 3862902.08 & 109.31 & $<.0001$ \\
Resíduo & 996 & 35198727.19 & 35340.09 & & \\
Total & 999 & 46787433.42 & & & \\
\hline
\end{tabular}

\begin{tabular}{cccc}
\hline $\mathbf{R}^{2}$ & C.V. & $\mathbf{Q M}^{2}$ & $\begin{array}{c}\text { Média comprimento } \\
\text { fibra alburno }\end{array}$ \\
\hline 0.247688 & 15.32094 & 187.9896 & 1227.011 \\
\hline
\end{tabular}

Comprimento fibra no cerne (alpha $=0,05)$ :

\begin{tabular}{lccccc}
\hline Fontes de variação & GL & $\begin{array}{c}\text { Soma de } \\
\text { Quadrados }\end{array}$ & $\begin{array}{c}\text { Quadrado } \\
\text { Médio }\end{array}$ & Valor F & Pr > F \\
\hline Idade (tratamentos) & 3 & 10976898.61 & 3658966.20 & 91.82 & $<.0001$ \\
Resíduo & 996 & 39689066.68 & 39848.46 & & \\
Total & 999 & 50665965.29 & & & \\
\hline
\end{tabular}

\begin{tabular}{cccc}
\hline $\mathbf{R}^{2}$ & C.V. & $\mathbf{Q M}^{2}$ & $\begin{array}{c}\text { Média } \\
\text { comprimento } \\
\text { fibra cerne }\end{array}$ \\
\hline 0.216652 & 17.92496 & 199.6208 & 1113.647 \\
\hline
\end{tabular}

Diâmetro total da fibra no alburno (alpha $=0,05)$ :

\begin{tabular}{lccccc}
\hline Fontes de variação & GL & $\begin{array}{c}\text { Soma de } \\
\text { Quadrados }\end{array}$ & $\begin{array}{c}\text { Quadrado } \\
\text { Médio }\end{array}$ & Valor F & Pr > F \\
\hline Idade (tratamentos) & 3 & 118.229773 & 39.409924 & 1.42 & 0.2385 \\
Resíduo & 196 & 5444.559821 & 27.778366 & & \\
Total & 199 & 5562.789594 & & & \\
\hline
\end{tabular}

\begin{tabular}{cccc}
\hline $\mathbf{R}^{2}$ & C.V. & $\mathbf{Q M}^{2}$ & $\begin{array}{c}\text { Média diâmetro } \\
\text { fibra alburno }\end{array}$ \\
\hline 0.021254 & 19.25537 & 5.270519 & 27.37168 \\
\hline
\end{tabular}


Diâmetro total da fibra no cerne (alpha $=0,05)$ :

\begin{tabular}{lccccc}
\hline Fontes de variação & GL & $\begin{array}{c}\text { Soma de } \\
\text { Quadrados }\end{array}$ & $\begin{array}{c}\text { Quadrado } \\
\text { Médio }\end{array}$ & Valor F & Pr > F \\
\hline Idade (tratamentos) & 3 & 225.553454 & 75.184485 & 3.37 & 0.0195 \\
Resíduo & 196 & 4369.565285 & 22.293700 & & \\
Total & 199 & 4595.118739 & & & \\
\hline
\end{tabular}

\begin{tabular}{cccc}
\hline $\mathbf{R}^{2}$ & C.V. & $\mathbf{Q M}^{2}$ & $\begin{array}{c}\text { Média diâmetro } \\
\text { fibra cerne }\end{array}$ \\
\hline 0.049085 & 18.00114 & 4.721621 & 26.22957 \\
\hline
\end{tabular}

Diâmetro do lúme da fibra no alburno (alpha $=0,05)$ :

\begin{tabular}{lccccc}
\hline Fontes de variação & GL & $\begin{array}{c}\text { Soma de } \\
\text { Quadrados }\end{array}$ & $\begin{array}{c}\text { Quadrado } \\
\text { Médio }\end{array}$ & Valor F & $\operatorname{Pr}>$ F \\
\hline Idade (tratamentos) & 3 & 60.322407 & 20.107469 & 0.90 & 0.4431 \\
Resíduo & 196 & 4387.124064 & 22.383286 & & \\
Total & 199 & 4447.446471 & & & \\
\hline
\end{tabular}

\begin{tabular}{cccc}
\hline $\mathbf{R}^{2}$ & C.V. & $\mathbf{Q M}^{2}$ & $\begin{array}{c}\text { Média diâmetro } \\
\text { lúme fibra alburno }\end{array}$ \\
\hline 0.013563 & 25.38250 & 4.731098 & 18.63921 \\
\hline
\end{tabular}

Diâmetro do lúme da fibra no cerne (alpha $=0,05)$ :

\begin{tabular}{lccccc}
\hline Fontes de variação & GL & $\begin{array}{c}\text { Soma de } \\
\text { Quadrados }\end{array}$ & $\begin{array}{c}\text { Quadrado } \\
\text { Médio }\end{array}$ & Valor F & $\operatorname{Pr}>$ F \\
\hline Idade (tratamentos) & 3 & 131.686981 & 43.895660 & 2.33 & 0.0759 \\
Resíduo & 196 & 3696.584513 & 18.860125 & & \\
Total & 199 & 3828.271493 & & & \\
\hline
\end{tabular}

\begin{tabular}{cccc}
\hline $\mathbf{R}^{2}$ & C.V. & $\mathbf{Q M}^{2}$ & $\begin{array}{c}\text { Média diâmetro } \\
\text { lúme fibra cerne }\end{array}$ \\
\hline 0.034399 & 24.45062 & 4.342825 & 17.76162 \\
\hline
\end{tabular}

Espessura da parede da fibra no alburno (alpha $=0,05$ ):

\begin{tabular}{lccccc}
\hline Fontes de variação & GL & $\begin{array}{c}\text { Soma de } \\
\text { Quadrados }\end{array}$ & $\begin{array}{c}\text { Quadrado } \\
\text { Médio }\end{array}$ & Valor F & $\operatorname{Pr}>$ F \\
\hline Idade (tratamentos) & 3 & 2.5803583 & 0.8601194 & 1.64 & 0.1822 \\
Resíduo & 196 & 103.0047137 & 0.5255343 & & \\
Total & 199 & 105.5850720 & & & \\
\hline
\end{tabular}

\begin{tabular}{cccc}
\hline $\mathbf{R}^{2}$ & C.V. & $\mathbf{Q M}^{2}$ & $\begin{array}{c}\text { Média espessura parede } \\
\text { fibra alburno }\end{array}$ \\
\hline 0.024439 & 16.60231 & 0.724937 & 4.366485 \\
\hline
\end{tabular}


Espessura da parede da fibra no cerne (alpha $=0,05)$

\begin{tabular}{lccccc}
\hline Fontes de variação & GL & $\begin{array}{c}\text { Soma de } \\
\text { Quadrados }\end{array}$ & $\begin{array}{c}\text { Quadrado } \\
\text { Médio }\end{array}$ & Valor F & $\operatorname{Pr}>$ F \\
\hline Idade (tratamentos) & 3 & 8.63524069 & 2.87841356 & 7.85 & $<.0001$ \\
Resíduo & 196 & 71.91077506 & 0.36689171 & & \\
Total & 199 & 80.54601576 & & & \\
\hline
\end{tabular}

\begin{tabular}{cccc}
\hline $\mathbf{R}^{2}$ & C.V. & $\mathbf{Q M}^{2}$ & $\begin{array}{c}\text { Média espessura } \\
\text { parede fibra cerne }\end{array}$ \\
\hline 0.107209 & 14.30527 & 0.605716 & 4.234215 \\
\hline
\end{tabular}

B7. Análise de variância dos elementos anatômicos - vaso (comprimento vaso, diâmetro vaso e frequência) Comprimento vaso no alburno (alpha $=0,05)$ :

\begin{tabular}{lccccc}
\hline Fontes de variação & GL & $\begin{array}{c}\text { Soma de } \\
\text { Quadrados }\end{array}$ & $\begin{array}{c}\text { Quadrado } \\
\text { Médio }\end{array}$ & Valor F & Pr > F \\
\hline Idade (tratamentos) & 3 & 16138.9635 & 5379.6545 & 1.43 & 0.2360 \\
Resíduo & 196 & 738641.5279 & 3768.5792 & & \\
Total & 199 & 754780.4915 & & & \\
\hline
\end{tabular}

\begin{tabular}{cccc}
\hline $\mathbf{R}^{2}$ & C.V. & $\mathbf{Q M}^{\mathbf{2}}$ & $\begin{array}{c}\text { Média comprimento } \\
\text { vaso alburno }\end{array}$ \\
\hline 0.021382 & 21.33034 & 61.38875 & 287.8001 \\
\hline
\end{tabular}

Comprimento vaso no cerne (alpha $=0,05)$ :

\begin{tabular}{lccccc}
\hline Fontes de variação & GL & $\begin{array}{c}\text { Soma de } \\
\text { Quadrados }\end{array}$ & $\begin{array}{c}\text { Quadrado } \\
\text { Médio }\end{array}$ & Valor F & Pr > F \\
\hline Idade (tratamentos) & 3 & 22438.4717 & 7479.4906 & 2.07 & 0.1061 \\
Resíduo & 196 & 709636.1155 & 3620.5924 & & \\
Total & 199 & 732074.5873 & & & \\
\hline
\end{tabular}

\begin{tabular}{cccc}
\hline $\mathbf{R}^{2}$ & C.V. & $\mathbf{Q M}^{2}$ & $\begin{array}{c}\text { Média comprimento } \\
\text { vaso cerne }\end{array}$ \\
\hline 0.030651 & 20.79256 & 60.17136 & 289.3889 \\
\hline
\end{tabular}


Diâmetro do vaso no alburno (alpha $=0,05)$ :

\begin{tabular}{lccccc}
\hline Fontes de variação & GL & $\begin{array}{c}\text { Soma de } \\
\text { Quadrados }\end{array}$ & $\begin{array}{c}\text { Quadrado } \\
\text { Médio }\end{array}$ & Valor F & Pr > F \\
\hline Idade (tratamentos) & 3 & 4372.6393 & 1457.5464 & 0.70 & 0.5570 \\
Resíduo & 76 & 159032.6602 & 2092.5350 & & \\
Total & 79 & 163405.2994 & & & \\
\hline
\end{tabular}

\begin{tabular}{cccc}
\hline $\mathbf{R}^{2}$ & C.V. & $\mathbf{Q M}^{2}$ & $\begin{array}{c}\text { Média diâmetro } \\
\text { vaso alburno }\end{array}$ \\
\hline 0.026759 & 26.78749 & 45.74423 & 170.7671 \\
\hline
\end{tabular}

Diâmetro do vaso no cerne (alpha $=0,05)$ :

\begin{tabular}{lrrrrr}
\hline Fontes de variação & GL & $\begin{array}{r}\text { Soma de } \\
\text { Quadrados }\end{array}$ & $\begin{array}{r}\text { Quadrado } \\
\text { Médio }\end{array}$ & Valor F & Pr > F \\
\hline Idade (tratamentos) & 3 & 2622.9612 & 874.3204 & 0.53 & 0.6645 \\
Resíduo & 76 & 125868.6615 & 1656.1666 & & \\
Total & 79 & 128491.6228 & & & \\
\hline
\end{tabular}

\begin{tabular}{cccc}
\hline $\mathbf{R}^{2}$ & C.V. & $\mathbf{Q M}^{2}$ & $\begin{array}{c}\text { Média diâmetro } \\
\text { vaso cerne }\end{array}$ \\
\hline 0.020413 & 25.28618 & 40.69603 & 160.9418 \\
\hline
\end{tabular}

Frequência de vaso no alburno (alpha $=0,05)$ :

\begin{tabular}{lrrrrr}
\hline Fontes de variação & GL & $\begin{array}{r}\text { Soma de } \\
\text { Quadrados }\end{array}$ & $\begin{array}{r}\text { Quadrado } \\
\text { Médio }\end{array}$ & Valor F & Pr > F \\
\hline Idade (tratamentos) & 3 & 32.3413750 & 10.7804583 & 3.65 & 0.0163 \\
Resíduo & 76 & 224.6225000 & 2.9555592 & & \\
Total & 79 & 256.9638750 & & & \\
\hline
\end{tabular}

\begin{tabular}{cccc}
\hline $\mathbf{R}^{2}$ & C.V. & $\mathbf{Q M}^{2}$ & $\begin{array}{c}\text { Média Frequência } \\
\text { vaso alburno }\end{array}$ \\
\hline 0.125860 & 34.88053 & 1.719174 & 4.928750 \\
\hline
\end{tabular}

Frequência de vaso no cerne (alpha $=0,05)$ :

\begin{tabular}{lccccc}
\hline Fontes de variação & GL & $\begin{array}{c}\text { Soma de } \\
\text { Quadrados }\end{array}$ & $\begin{array}{c}\text { Quadrado } \\
\text { Médio }\end{array}$ & Valor F & $\operatorname{Pr}>$ F \\
\hline Idade (tratamentos) & 3 & 3.4053750 & 1.1351250 & 0.68 & 0.5699 \\
Resíduo & 76 & 127.7695000 & 1.6811776 & & \\
Total & 79 & 131.1748750 & & & \\
\hline
\end{tabular}

\begin{tabular}{cccc}
\hline $\mathbf{R}^{2}$ & C.V. & $\mathbf{Q M}^{2}$ & $\begin{array}{c}\text { Média frequência } \\
\text { vaso cerne }\end{array}$ \\
\hline 0.025961 & 26.38723 & 1.296602 & 4.913750 \\
\hline
\end{tabular}


B8. Análise de variância do teor de extrativos na madeira (alpha $=0,05)$

\begin{tabular}{lccccc}
\hline Fontes de variação & GL & $\begin{array}{c}\text { Soma de } \\
\text { Quadrados }\end{array}$ & $\begin{array}{c}\text { Quadrado } \\
\text { Médio }\end{array}$ & Valor F & $\operatorname{Pr}>$ F \\
\hline Idade (tratamentos) & 3 & 156.7654600 & 52.2551533 & 29.35 & $<.0001$ \\
Resíduo & 56 & 99.7084800 & 1.7805086 & & \\
Total & 59 & 256.4739400 & & & \\
\hline
\end{tabular}

\begin{tabular}{cccc}
\hline $\mathbf{R}^{2}$ & C.V. & $\mathbf{Q M}^{2}$ & $\begin{array}{c}\text { Média teor de } \\
\text { extrativos }\end{array}$ \\
\hline 0.611233 & 13.63119 & 1.334357 & 9.789000 \\
\hline
\end{tabular}

B9. Análise de variância das propriedades mecânicas da madeira (resistência ao cisalhamento, resistência a compressão paralela às fibras, dureza, Flexão Estática - MOR e MOE)

Resistência ao cisalhamento (alpha $=0,05)$ :

\begin{tabular}{lccccc}
\hline Fontes de variação & GL & $\begin{array}{c}\text { Soma de } \\
\text { Quadrados }\end{array}$ & $\begin{array}{c}\text { Quadrado } \\
\text { Médio }\end{array}$ & Valor F & Pr > F \\
\hline Idade (tratamentos) & 3 & 46.82908271 & 15.60969424 & 5.91 & 0.0065 \\
Resíduo & 16 & 42.26114695 & 2.64132168 & & \\
Total & 19 & 89.09022966 & & & \\
\hline
\end{tabular}

\begin{tabular}{cccc}
\hline $\mathbf{R}^{2}$ & C.V. & $\mathbf{Q M}^{2}$ & $\begin{array}{c}\text { Média resistência } \\
\text { cisalhamento }\end{array}$ \\
\hline 0.525637 & 10.85069 & 1.625214 & 14.97798 \\
\hline
\end{tabular}

Resistência a compressão paralela (alpha $=0,05)$ :

\begin{tabular}{lccccc}
\hline Fontes de variação & GL & $\begin{array}{c}\text { Soma de } \\
\text { Quadrados }\end{array}$ & $\begin{array}{c}\text { Quadrado } \\
\text { Médio }\end{array}$ & Valor F & Pr > F \\
\hline Idade (tratamentos) & 3 & 204.9811914 & 68.3270638 & 5.38 & 0.0094 \\
Resíduo & 16 & 203.1806558 & 12.6987910 & & \\
Total & 19 & 408.1618472 & & & \\
\hline
\end{tabular}

\begin{tabular}{cccc}
\hline $\mathbf{R}^{2}$ & C.V. & $\mathbf{Q M}^{2}$ & $\begin{array}{c}\text { Média resistência } \\
\text { compressão paralela }\end{array}$ \\
\hline 0.502206 & 9.121557 & 3.563536 & 39.06720 \\
\hline
\end{tabular}


Dureza (alpha $=0,05)$ :

\begin{tabular}{lccccc}
\hline Fontes de variação & GL & $\begin{array}{c}\text { Soma de } \\
\text { Quadrados }\end{array}$ & $\begin{array}{c}\text { Quadrado } \\
\text { Médio }\end{array}$ & Valor F & $\operatorname{Pr}>$ F \\
\hline Idade (tratamentos) & 3 & 17883.09838 & 5961.03279 & 1.95 & 0.1627 \\
Resíduo & 16 & 48981.85890 & 3061.36618 & & \\
Total & 19 & 66864.95728 & & & \\
\hline
\end{tabular}

\begin{tabular}{cccc}
\hline $\mathbf{R}^{2}$ & C.V. & $\mathbf{Q M}^{2}$ & Média Dureza \\
\hline 0.267451 & 15.58507 & 55.32961 & 355.0168 \\
\hline
\end{tabular}

Flexão Estática - MOR (alpha = 0,05):

\begin{tabular}{lccccc}
\hline Fontes de variação & GL & $\begin{array}{c}\text { Soma de } \\
\text { Quadrados }\end{array}$ & $\begin{array}{c}\text { Quadrado } \\
\text { Médio }\end{array}$ & Valor F & $\operatorname{Pr}>$ F \\
\hline Idade (tratamentos) & 3 & 79198.0358 & 26399.3453 & 3.14 & 0.0544 \\
Resíduo & 16 & 134505.0474 & 8406.5655 & & \\
Total & 19 & 213703.0832 & & & \\
\hline
\end{tabular}

\begin{tabular}{cccc}
\hline $\mathbf{R}^{2}$ & C.V. & $\mathbf{Q M}^{2}$ & $\begin{array}{c}\text { Média Flexão Estática } \\
\text { MOR }\end{array}$ \\
\hline 0.370598 & 9.835686 & 91.68732 & 932.1904 \\
\hline
\end{tabular}

Flexão Estática - MOE (alpha = 0,05):

\begin{tabular}{lccccc}
\hline Fontes de variação & GL & $\begin{array}{c}\text { Soma de } \\
\text { Quadrados }\end{array}$ & $\begin{array}{c}\text { Quadrado } \\
\text { Médio }\end{array}$ & Valor F & $\operatorname{Pr}>$ F \\
\hline Idade (tratamentos) & 3 & 511093379 & 170364460 & 0.66 & 0.5867 \\
Resíduo & 16 & 4110807080 & 256925443 & & \\
Total & 19 & 4621900460 & & & \\
\hline
\end{tabular}

\begin{tabular}{cccc}
\hline $\mathbf{R}^{2}$ & C.V. & $\mathbf{Q M}^{2}$ & $\begin{array}{c}\text { Média Flexão Estática } \\
\text { MOE }\end{array}$ \\
\hline 0.110581 & 14.94897 & 16028.89 & 107224.0 \\
\hline
\end{tabular}


B10. Análise de variância do rendimento de produção de piso em volume (volume tora por árvore e por hectare; volume tábua por árvore e por hectare e volume piso por árvore e por hectare)

Volume tora por árvore (alpha $=0,05)$ :

\begin{tabular}{lccccc}
\hline Fontes de variação & GL & $\begin{array}{c}\text { Soma de } \\
\text { Quadrados }\end{array}$ & $\begin{array}{c}\text { Quadrado } \\
\text { Médio }\end{array}$ & Valor F & Pr > F \\
\hline Idade (tratamentos) & 3 & $1.4980044 \mathrm{E} 12$ & 499334796389 & 156.33 & $<.0001$ \\
Resíduo & 16 & 51105989583 & 3194124348.9 & & \\
Total & 19 & $1.5491104 \mathrm{E} 12$ & & & \\
\hline
\end{tabular}

\begin{tabular}{cccc}
\hline $\mathbf{R}^{2}$ & C.V. & $\mathbf{Q M}^{2}$ & $\begin{array}{c}\text { Média volume } \\
\text { tora por árvore }\end{array}$ \\
\hline 0.967009 & 12.52379 & 56516.58 & 451273.8 \\
\hline
\end{tabular}

Volume tora por hectare (alpha $=0,05)$ :

\begin{tabular}{lccccc}
\hline Fontes de variação & GL & $\begin{array}{c}\text { Soma de } \\
\text { Quadrados }\end{array}$ & $\begin{array}{c}\text { Quadrado } \\
\text { Médio }\end{array}$ & Valor F & Pr > F \\
\hline Idade (tratamentos) & 3 & 4922.089560 & 1640.696520 & 14.93 & $<.0001$ \\
Resíduo & 16 & 1758.085760 & 109.880360 & & \\
Total & 19 & 6680.175320 & & & \\
\hline
\end{tabular}

\begin{tabular}{cccc}
\hline $\mathbf{R}^{2}$ & C.V. & $\mathbf{Q M}^{2}$ & $\begin{array}{c}\text { Média Volume } \\
\text { tora por hectare }\end{array}$ \\
\hline 0.736820 & 9.149486 & 10.48238 & 114.5680 \\
\hline
\end{tabular}

Volume tábua por árvore (alpha $=0,05)$ :

\begin{tabular}{lccccc}
\hline Fontes de variação & GL & $\begin{array}{c}\text { Soma de } \\
\text { Quadrados }\end{array}$ & $\begin{array}{c}\text { Quadrado } \\
\text { Médio }\end{array}$ & Valor F & $\operatorname{Pr}>$ F \\
\hline Idade (tratamentos) & 3 & 276257868301 & 92085956100 & 139.48 & $<.0001$ \\
Resíduo & 16 & 10563297108 & 660206069.23 & & \\
Total & 19 & 286821165408 & & & \\
\hline
\end{tabular}

\begin{tabular}{cccc}
\hline $\mathbf{R}^{2}$ & C.V. & $\mathbf{Q M}^{2}$ & $\begin{array}{c}\text { Média volume } \\
\text { tábua por árvore }\end{array}$ \\
\hline 0.963171 & 13.93096 & 25694.48 & 184441.5 \\
\hline
\end{tabular}


Volume tábua por hectare (alpha $=0,05)$ :

\begin{tabular}{lccccc}
\hline Fontes de variação & GL & $\begin{array}{c}\text { Soma de } \\
\text { Quadrados }\end{array}$ & $\begin{array}{c}\text { Quadrado } \\
\text { Médio }\end{array}$ & Valor F & Pr > F \\
\hline Idade (tratamentos) & 3 & 849.619935 & 283.206645 & 12.97 & 0.0001 \\
Resíduo & 16 & 349.421120 & 21.838820 & & \\
Total & 19 & 1199.041055 & & & \\
\hline
\end{tabular}

\begin{tabular}{cccc}
\hline $\mathbf{R}^{2}$ & C.V. & $\mathbf{Q M}^{2}$ & $\begin{array}{c}\text { Média Volume } \\
\text { tábua por hectare }\end{array}$ \\
\hline 0.708583 & 10.26096 & 4.673202 & 45.54350 \\
\hline
\end{tabular}

Volume de piso por árvore (alpha $=0,05)$ :

\begin{tabular}{lccccc}
\hline Fontes de variação & GL & $\begin{array}{c}\text { Soma de } \\
\text { Quadrados }\end{array}$ & $\begin{array}{c}\text { Quadrado } \\
\text { Médio }\end{array}$ & Valor F & $\operatorname{Pr}>$ F \\
\hline Idade (tratamentos) & 3 & 87428731071 & 29142910357 & 87.02 & $<.0001$ \\
Resíduo & 16 & 5358454761 & 334903423 & & \\
Total & 19 & 92787185832 & & & \\
\hline
\end{tabular}

\begin{tabular}{cccc}
\hline $\mathbf{R}^{2}$ & C.V. & $\mathbf{Q M}^{2}$ & $\begin{array}{c}\text { Média volume } \\
\text { piso por árvore }\end{array}$ \\
\hline 0.942250 & 18.29741 & 18300.37 & 100016.2 \\
\hline
\end{tabular}

Volume de piso por hectare (alpha $=0,05)$ :

\begin{tabular}{lccccc}
\hline Fontes de variação & GL & $\begin{array}{c}\text { Soma de } \\
\text { Quadrados }\end{array}$ & $\begin{array}{c}\text { Quadrado } \\
\text { Médio }\end{array}$ & Valor F & $\operatorname{Pr}>$ F \\
\hline Idade (tratamentos) & 3 & 329.5526600 & 109.8508867 & 9.68 & 0.0007 \\
Resíduo & 16 & 181.5234400 & 11.3452150 & & \\
Total & 19 & 511.0761000 & & & \\
\hline
\end{tabular}

\begin{tabular}{cccc}
\hline $\mathbf{R}^{2}$ & C.V. & $\mathbf{Q M}^{2}$ & $\begin{array}{c}\text { Média volume } \\
\text { piso por hectare }\end{array}$ \\
\hline 0.644821 & 13.95594 & 3.368266 & 24.13500 \\
\hline
\end{tabular}


B11. Análise de variância do rendimento de produção de piso em área (área tábua por árvore e por hectare e área piso por árvore e por hectare)

Área tábua por árvore (alpha $=0,05)$ :

\begin{tabular}{lccccc}
\hline Fontes de variação & GL & $\begin{array}{c}\text { Soma de } \\
\text { Quadrados }\end{array}$ & $\begin{array}{c}\text { Quadrado } \\
\text { Médio }\end{array}$ & Valor F & $\operatorname{Pr}>$ F \\
\hline Idade (tratamentos) & 3 & 41196865803 & 13732288601 & 133.16 & $<.0001$ \\
Resíduo & 16 & 1650044208 & 103127763 & & \\
Total & 19 & 42846910010 & & & \\
\hline
\end{tabular}

\begin{tabular}{cccc}
\hline $\mathbf{R}^{2}$ & C.V. & $\mathbf{Q M}^{2}$ & $\begin{array}{c}\text { Média área tábua } \\
\text { por árvore }\end{array}$ \\
\hline 0.961490 & 14.02645 & 10155.18 & 72400.24 \\
\hline
\end{tabular}

Área tábua por hectare (alpha $=0,05)$ :

\begin{tabular}{lrrrrr}
\hline Fontes de variação & GL & $\begin{array}{r}\text { Soma de } \\
\text { Quadrados }\end{array}$ & $\begin{array}{r}\text { Quadrado } \\
\text { Médio }\end{array}$ & Valor F & Pr > F \\
\hline Idade (tratamentos) & 3 & 1037652.369 & 345884.123 & 9.73 & 0.0007 \\
Resíduo & 16 & 568631.475 & 35539.467 & & \\
Total & 19 & 1606283.843 & & & \\
\hline
\end{tabular}

\begin{tabular}{cccc}
\hline $\mathbf{R}^{2}$ & C.V. & $\mathbf{Q M}^{2}$ & $\begin{array}{c}\text { Média área tábua } \\
\text { por hectare }\end{array}$ \\
\hline 0.645996 & 10.41387 & 188.5191 & 1810.270 \\
\hline
\end{tabular}

Área piso por árvore (alpha $=0,05)$ :

\begin{tabular}{lccccc}
\hline Fontes de variação & GL & $\begin{array}{c}\text { Soma de } \\
\text { Quadrados }\end{array}$ & $\begin{array}{c}\text { Quadrado } \\
\text { Médio }\end{array}$ & Valor F & Pr > F \\
\hline Idade (tratamentos) & 3 & 24218485287 & 8072828429 & 87.02 & $<.0001$ \\
Resíduo & 16 & 1484336492 & 92771031 & & \\
Total & 19 & 25702821779 & & & \\
\hline
\end{tabular}

\begin{tabular}{cccc}
\hline $\mathbf{R}^{2}$ & C.V. & $\mathbf{Q M}^{2}$ & $\begin{array}{c}\text { Média área piso } \\
\text { por árvore }\end{array}$ \\
\hline 0.942250 & 18.29741 & 9631.772 & 52640.10 \\
\hline
\end{tabular}


Área piso por hectare (alpha $=0,05)$ :

\begin{tabular}{lccccc}
\hline Fontes de variação & GL & $\begin{array}{c}\text { Soma de } \\
\text { Quadrados }\end{array}$ & $\begin{array}{c}\text { Quadrado } \\
\text { Médio }\end{array}$ & Valor F & $\operatorname{Pr}>$ F \\
\hline Idade (tratamentos) & 3 & 913232.321 & 304410.774 & 9.68 & 0.0007 \\
Resíduo & 16 & 502902.129 & 31431.383 & & \\
Total & 19 & 1416134.449 & & & \\
\hline
\end{tabular}

\begin{tabular}{cccc}
\hline $\mathbf{R}^{2}$ & C.V. & $\mathbf{Q M}^{2}$ & $\begin{array}{c}\text { Média área piso } \\
\text { por hectare }\end{array}$ \\
\hline 0.644877 & 13.95703 & 177.2890 & 1270.248 \\
\hline
\end{tabular}

B12. Análise de variância da qualidade do piso (brilho, dureza - impacto de bola, rugosidade) Brilho do piso (alpha $=0,05)$ :

\begin{tabular}{lccccc}
\hline Fontes de variação & GL & $\begin{array}{c}\text { Soma de } \\
\text { Quadrados }\end{array}$ & $\begin{array}{c}\text { Quadrado } \\
\text { Médio }\end{array}$ & Valor F & $\operatorname{Pr}>$ F \\
\hline Idade (tratamentos) & 3 & 0.64500000 & 0.21500000 & 0.32 & 0.8138 \\
Resíduo & 16 & 10.89268000 & 0.68079250 & & \\
Total & 19 & 11.53768000 & & & \\
\hline
\end{tabular}

\begin{tabular}{cccc}
\hline $\mathbf{R}^{2}$ & C.V. & $\mathbf{Q M}^{2}$ & $\begin{array}{c}\text { Média brilho do } \\
\text { piso }\end{array}$ \\
\hline 0.055904 & 2.223035 & 0.825102 & 37.11600 \\
\hline
\end{tabular}

Dureza do piso - impacto de bola (alpha $=0,05)$ :

\begin{tabular}{lccccc}
\hline Fontes de variação & GL & $\begin{array}{c}\text { Soma de } \\
\text { Quadrados }\end{array}$ & $\begin{array}{c}\text { Quadrado } \\
\text { Médio }\end{array}$ & Valor F & Pr > F \\
\hline Idade (tratamentos) & 3 & 0.00258000 & 0.00086000 & 0.31 & 0.8179 \\
Resíduo & 16 & 0.04440000 & 0.00277500 & & \\
Total & 19 & 0.04698000 & & & \\
\hline
\end{tabular}

\begin{tabular}{cccc}
\hline $\mathbf{R}^{2}$ & C.V. & $\mathbf{Q M}^{2}$ & $\begin{array}{c}\text { Média Dureza do } \\
\text { piso }\end{array}$ \\
\hline 0.054917 & 13.47270 & 0.052678 & 0.391000 \\
\hline
\end{tabular}


Rugosidade do piso (alpha $=0,05)$ :

\begin{tabular}{lccccc}
\hline Fontes de variação & GL & $\begin{array}{c}\text { Soma de } \\
\text { Quadrados }\end{array}$ & $\begin{array}{c}\text { Quadrado } \\
\text { Médio }\end{array}$ & Valor F & Pr > F \\
\hline Idade (tratamentos) & 3 & 0.00017500 & 0.00005833 & 0.03 & 0.9939 \\
Resíduo & 16 & 0.03508000 & 0.00219250 & & \\
Total & 19 & 0.03525500 & & & \\
\hline
\end{tabular}

\begin{tabular}{cccc}
\hline $\mathbf{R}^{2}$ & C.V. & $\mathbf{Q M}^{2}$ & $\begin{array}{c}\text { Média rugosidade } \\
\text { do piso }\end{array}$ \\
\hline 0.004964 & 4.620043 & 0.046824 & 1.013500 \\
\hline
\end{tabular}

